Evaluation of Juvenile Salmonid Outmigration and Survival in the Lower Umatilla River Basin

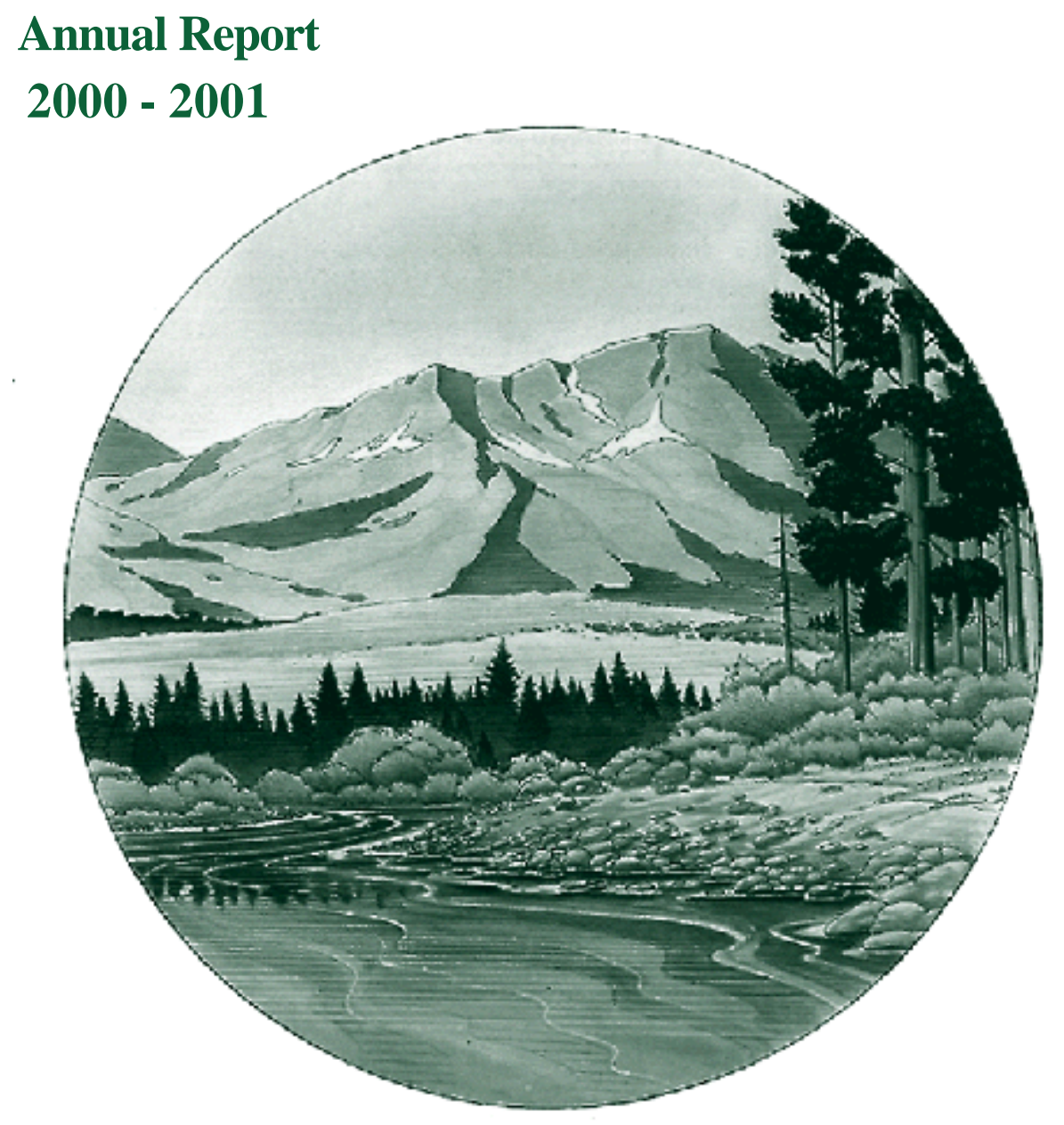

DOE/BP-00004340-3

April 2003 
This Document should be cited as follows:

White, Tara, Shannon Jewett, Josh Hanson, Richard Carmichael, "Evaluation of Juvenile Salmonid Outmigration and Survival in the Lower Umatilla River Basin", Project No. 198902401, 122 electronic pages, (BPA Report DOE/BP-00004340-3)

Bonneville Power Administration

P.O. Box 3621

Portland, Oregon 97208

This report was funded by the Bonneville Power Administration (BPA), U.S. Department of Energy, as part of BPA's program to protect, mitigate, and enhance fish and wildlife affected by the development and operation of hydroelectric facilities on the Columbia River and its tributaries. The views in this report are the author's and do not necessarily represent the views of BPA. 


\title{
EVALUATION OF JUVENILE SALMONID OUTMIGRATION AND SURVIVAL IN THE LOWER UMATILLA RIVER BASIN
}

\author{
ANNUAL REPORT 2001 \\ (1 OCTOBER 2000 - 30 SEPTEMBER 2001) \\ Prepared by: \\ Tara C. White \\ Shannon M. Jewett \\ Josh T. Hanson \\ Richard W. Carmichael
Oregon Department of Fish and Wildlife
2501 S.W. First Avenue
P.O. Box 59
Portland, OR 97207

Prepared for:

\author{
U.S. Department of Energy \\ Bonneville Power Administration \\ Environment, Fish and Wildlife \\ P.O. Box 3621 \\ Portland, OR 97208-3621 \\ Project Number 1989-024-01 \\ Contract Number 00000152-00001
}

March 2003 
This report was funded by the Bonneville Power Administration (BPA), U.S. Department of Energy, as part of BPA's program to protect, mitigate, and enhance fish and wildlife affected by the development and operation of hydroelectric facilities on the Columbia River and its tributaries. The views of this report are the author's and do not necessarily represent the views of BPA.

This document should be cited as follows:

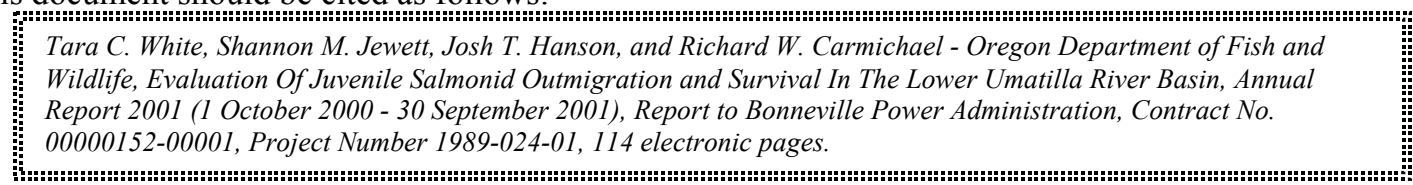

This report and other BPA Fish and Wildlife Publications are available on the Internet at:

http://www.efw.bpa.gov/cgi-bin/efw/FW/publications.cgi

For other information on electronic documents or other printed media, contact or write to:

Bonneville Power Administration

Environment, Fish and Wildlife Division

P.O. Box 3621

905 N.E. 11 th Avenue

Portland, OR 97208-3621

Please include title, author, and DOE/BP number in the request. 


\section{TABLE OF CONTENTS}

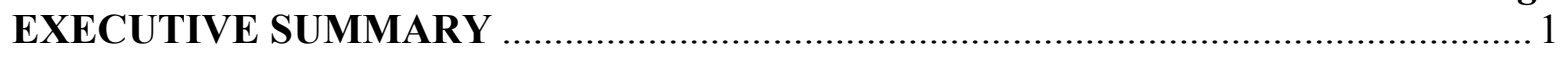

INTRODUCTION

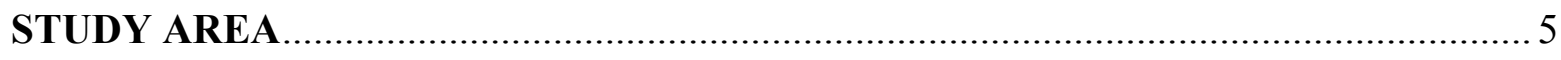

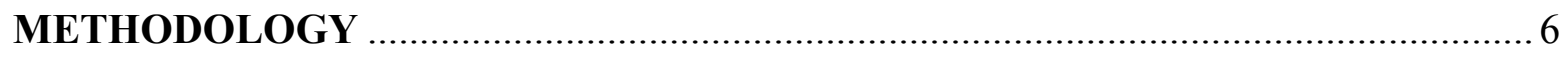

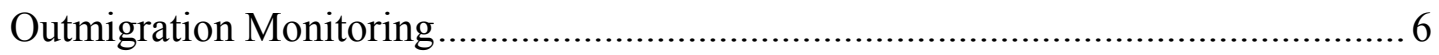

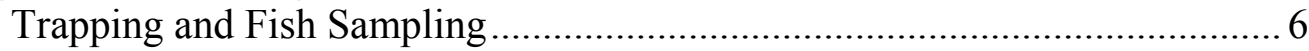

PIT-Tag Operations ......................................................................... 7

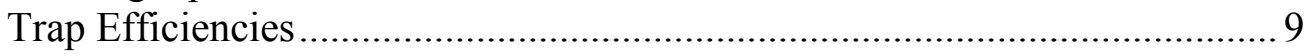

Migration Parameters .................................................................... 10

Length Analysis .......................................................................... 10

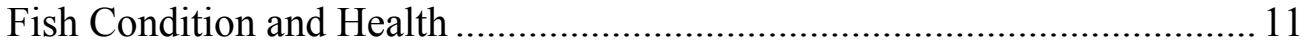

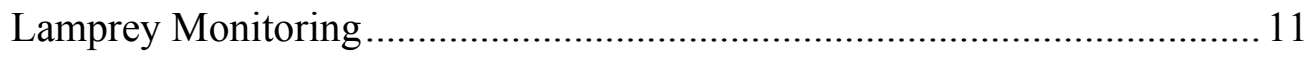

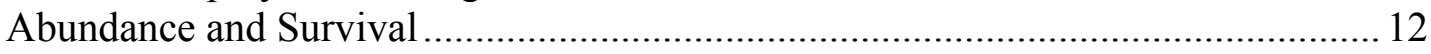

Migrant Abundance and Survival ........................................................ 12

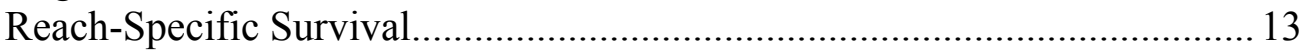

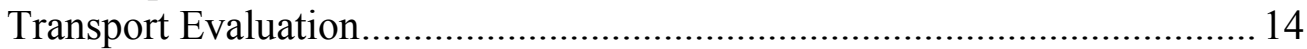

Environmental Conditions and Bypass Operations ............................................. 15

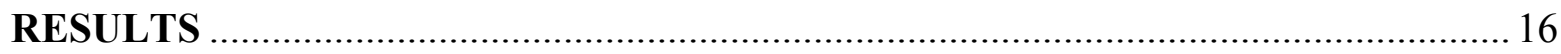

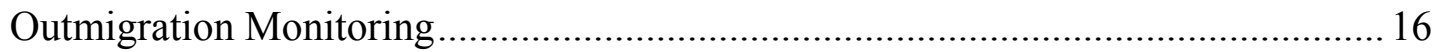

Trapping and Fish Sampling ........................................................... 16

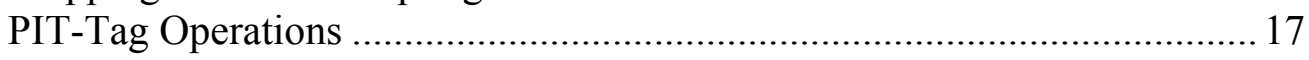

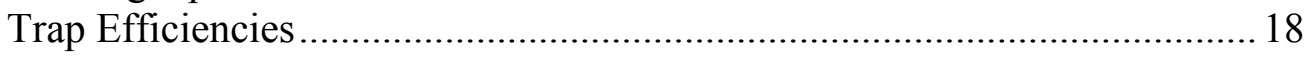

Migration Parameters .................................................................... 19

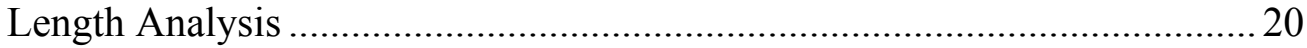

Fish Condition and Health ............................................................. 21

Lamprey Monitoring ......................................................................... 21

Abundance and Survival ............................................................................. 22

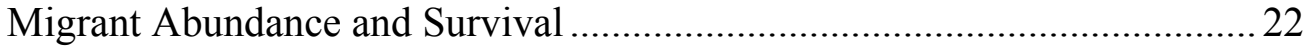

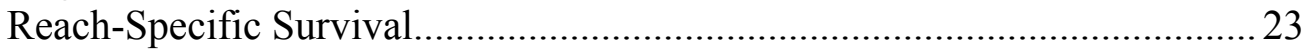

Transport Evaluation........................................................................... 23

Environmental Conditions and Bypass Operations ......................................... 24

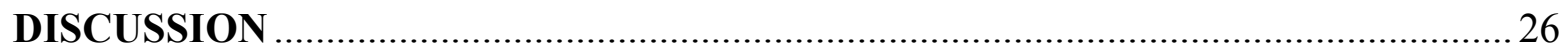

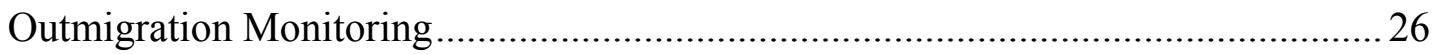

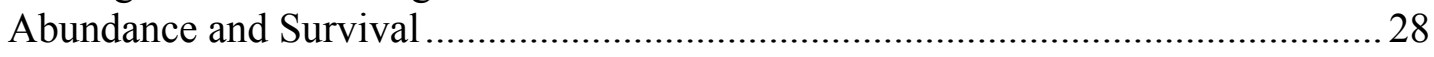

Environmental Conditions and Bypass Operations ............................................ 32 


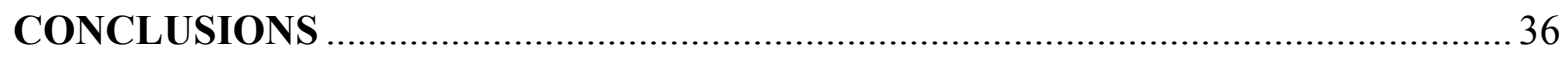

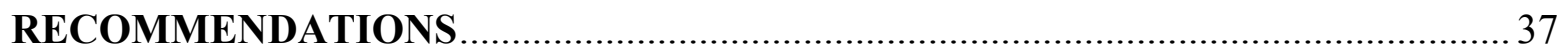

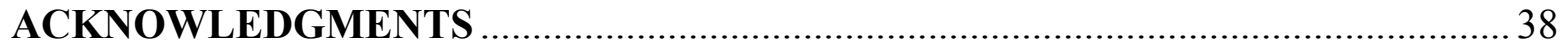

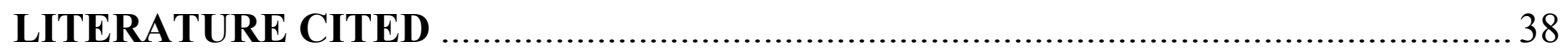

\section{LIST OF TABLES}

Table 1. Comparison of various hatchery, rearing, acclimation and release strategies applied in 2001, Umatilla River.

Table 2. Actual and adjusted sample numbers of juvenile salmonids at RM 1.2 and 3.7, Umatilla River, October 2000 - September 2001.

Table 3. PIT-tagged production fish from various hatchery, rearing and release strategies detected at West Extension Canal, RM 3.7, Umatilla River, March - September 2001 ....... 47

Table 4. Natural fish PIT tagged by CTUIR in the upper Umatilla River and detected at West Extension Canal, RM 3.7, Umatilla River, March - September 2001

Table 5. Percent holding survival and tag retention of hatchery and natural juvenile salmonids tagged for trap efficiency tests at West Extension Canal, RM 3.7, Umatilla River, spring 2001

Table 6. Trap efficiency estimates for hatchery and natural juvenile salmonids at West

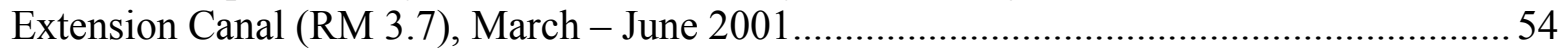

Table 7. Migration parameters of PIT-tagged hatchery, reach survival, and natural salmonids detected at West Extension Canal, RM 3.7, Umatilla River, March - September 2001

Table 8. Detection and travel speed of PIT-tagged hatchery summer steelhead released for reach survival tests and interrogated in the lower Umatilla River and mainstem Columbia River sites, March - July 2001

Table 9. Summary of scale loss and mortality of hatchery and natural juvenile salmonids collected at RM 1.2 and RM 3.7, Umatilla River, October 2000 September 2001 
Table 10. Total number and percentage of bird marks, body injuries, and parasites observed on juvenile salmonids sampled at RM 1.2 and RM 3.7, Umatilla River, October 2000 - September 2001.

Table 11. Correlation of mean daily river flow $\left(\mathrm{ft}^{3} / \mathrm{s}\right)$ and capture of juvenile Pacific lamprey at RM 1.2 and 3.7, Umatilla River, December 2000 - May 2001.

Table 12. Mark - recapture data, abundance estimates, and confidence intervals of emigrating juvenile lamprey, Umatilla River, October 2000 - September 2001. 65

Table 13. Detection, abundance, and survival of PIT-tagged production fish released into the upper Umatilla River and detected in the lower river, March - June 2001

Table 14. Detection, abundance, and survival of PIT-tagged natural fish released into the upper Umatilla River and tributaries and detected in the lower river, March - June 2001 ... 68

Table 15. Monthly abundance estimates for natural fish sampled in the lower Umatilla River, 2001

Table 16. Detection, abundance, and survival of PIT-tagged summer steelhead released for reach-specific survival tests and interrogated at West Extension Canal (RM 3.7), March - July 2001

Table 17. Summary of PIT-tagged hatchery subyearling fall chinook salmon released for trap and haul operations (transportation evaluation studies), Umatilla River, June August 2001

Table 18. Correlation of daily PIT tag detections with mean daily river flow $\left(\mathrm{ft}^{3} / \mathrm{s}\right)$ and water temperature $\left({ }^{\circ} \mathrm{C}\right)$ at RM 3.7, Umatilla River, March - June 2001

Table 19. Percentage of total natural chinook salmon and steelhead detections within given environmental categories. Number in parenthesis is the percentage of the total detection period within each environmental category.

Table 20. Correlations between travel speed (mi/d) and mean daily river flow $\left(\mathrm{ft}^{3} / \mathrm{s}\right)$ within various migration corridors of the Umatilla River

Table 21. Correlation between daily canal diversion rate and daily trap efficiency estimates at RM 3.7, Umatilla River, March - July 2001 74

Table 22. Correlation between daily PIT tag detections at RM 3.7 with daily water discharge $\left(\mathrm{ft}^{3} / \mathrm{s}\right)$ from McKay Reservoir, Umatilla River, March - June 2001 


\section{LIST OF FIGURES}

Figure 1. Detailed study area map and release locations, Umatilla River 2001 75

Figure 2. Parameters used to identify the origin of juvenile salmonids, Umatilla River, 2001. 76

Figure 3. Remote PIT-tag interrogation system $(134 \mathrm{kHz})$ used at West Extension Canal (RM 3.7) in 2001....

Figure 4. Temporary set up of portable detection system at east-bank viewing window, Three Mile Falls Dam (RM 3.7), lower Umatilla River

Figure 5. Daily species composition of juvenile salmonids sampled at RM 1.2, Umatilla River, October 2000 - March 2001

Figure 6. Weekly species composition of hatchery origin juvenile salmonids sampled at RM 3.7, Umatilla River, March - September 2001

Figure 7. Weekly species composition of natural and unknown origin juvenile salmonids sampled at RM 3.7, Umatilla River, March - September 2001

Figure 8. Percent and cumulative percent detection of PIT-tagged hatchery and natural spring chinook salmon at RM 3.7, Umatilla River, March - May 2001

Figure 9. Diel detection of PIT-tagged hatchery and natural spring chinook salmon at West Extension Canal (RM 3.7), Umatilla River, March - May 2001

Figure 10. Percent and cumulative percent detection of PIT-tagged hatchery yearling and subyearling fall chinook salmon at West Extension Canal (RM 3.7), Umatilla River, March - June 2001

Figure 11. Diel detection of PIT-tagged hatchery yearling and subyearling fall chinook salmon and coho salmon at West Extension Canal (RM 3.7), Umatilla River, March May 2001

Figure 12. Percent and cumulative percent detection of PIT-tagged hatchery coho salmon at West Extension Canal (RM 3.7), Umatilla River, March - May 2001

Figure 13. Percent and cumulative percent detection of PIT-tagged hatchery and natural summer steelhead at West Extension Canal (RM 3.7), Umatilla River, March - June 200186 
Figure 14. Diel detection of PIT-tagged hatchery and natural summer steelhead at West Extension Canal (RM 3.7), Umatilla River, March - June 2001

Figure 15. Length frequency distribution of yearling hatchery and natural chinook salmon of spring, fall, and unknown races captured at RM 3.7, Umatilla River, March - May 2001 88

Figure 16. Length frequency distribution of hatchery and natural subyearling chinook salmon of fall and unknown race captured at RM 3.7, Umatilla River, May September 2001 89

Figure 17. Length frequency distribution of hatchery and unknown origin coho salmon captured at RM 3.7, Umatilla River, March - June 2001

Figure 18. Length frequency distribution of hatchery and natural summer steelhead captured at RM 3.7, Umatilla River, March - June 2001

Figure 19. River flow (ft3/s) recorded at RM 2.1 and number of juvenile Pacific lamprey sampled at RM 1.2 and RM 3.7, Umatilla River, October 2000 - May 2001 92

Figure 20. Length-frequency distribution by calendar quarter of juvenile Pacific lamprey sampled at RM 1.2 and RM 3.7, Umatilla River, December 2000 - May 2001

Figure 21. Average weekly river flow $\left(\mathrm{ft}^{3} / \mathrm{s}\right)$ at RM 2.1, Umatilla River, October September $1998-2001$

Figure 22. Average weekly release flow $\left(\mathrm{ft}^{3} / \mathrm{s}\right)$ from McKay Reservoir, October September $1998-2001$ 94

Figure 23. Mean daily secchi depth (m) and river flow $\left(\mathrm{ft}^{3} / \mathrm{s}\right)$, Umatilla River, October 2000 - September 2001 95

Figure 24. Mean daily water temperature $\left({ }^{\circ} \mathrm{C}\right)$ and river flow $\left(\mathrm{ft}^{3} / \mathrm{s}\right)$, Umatilla River, October 2000 - September 2001 95

Figure 25 . Daily river flow index $\left(\mathrm{ft}^{3} / \mathrm{s} / 100\right)$, mean water temperature $\left({ }^{\circ} \mathrm{C}\right)$, and percent detection of PIT tagged natural summer steelhead (NSTS) at RM 3.7, Umatilla River, March - May 2001 96

Figure 26. Daily river flow index $\left(\mathrm{ft}^{3} / \mathrm{s} / 100\right)$, mean water temperature $\left({ }^{\circ} \mathrm{C}\right)$, and percent detection of PIT tagged natural chinook salmon (NCH) at RM 3.7, Umatilla River, March - May 2001 
Figure 27. Daily river flow index $\left(\mathrm{ft}^{3} / \mathrm{s} / 100\right)$, mean water temperature $\left({ }^{\circ} \mathrm{C}\right)$, and percent detection of PIT tagged hatchery spring chinook (HCHS), yearling fall chinook (HCHF), and coho (HCOH) salmon at RM 3.7, Umatilla River, 2001

Figure 28. Daily river flow index $\left(\mathrm{ft}^{3} / \mathrm{s} / 100\right)$, mean water temperature $\left({ }^{\circ} \mathrm{C}\right)$, and percent detection of PIT tagged hatchery large (HSTS (large)) and small-grade (HSTS (small)) summer steelhead and subyearling fall chinook salmon (HCHF0) at RM 3.7, Umatilla River, 2001 98

\section{LIST OF APPENDIX TABLES}

Appendix Table 1. Maximum monthly fork length used to determine origin of unmarked juvenile chinook salmon and coho, Umatilla River, October 2000 September 2001 100

Appendix Table 2. Correlation of mean daily river flow $\left(\mathrm{ft}^{3} / \mathrm{s}\right)$ and capture of juvenile Pacific lamprey at RM 1.2 and 3.7, Umatilla River, December 2000 - May 2001.

Appendix Table 3. Pacific lamprey captured at RM 1.2 and RM 3.7, 1995 - 2001

Appendix Table 4. Mean length, tag loss, and handling mortality of tagged fish used in reach-survival tests, Umatilla River, March - April 2001

Appendix Table 5. PIT-tag recoveries at mainstem Columbia River Islands from hatchery summer steelhead released for reach-specific survival tests in the Umatilla River, 2001.....103

Appendix Table 6. Daily observations at RM 1.2, Umatilla River, October 2000 - March 2000.

Appendix Table 7. Daily observations at the West Extension Canal sampling facility (RM 3.7), 9 March - 28 September 2001

Appendix Table 8. Releases of hatchery chinook salmon, coho salmon, and summer steelhead in the Umatilla River, March 2001 - June 2001.

Appendix Table 9. Mean pooled trap efficiency estimates for hatchery and natural juvenile salmonids at West Extension Canal (RM 3.7), March - July 1998-2001. 


\section{EXECUTIVE SUMMARY}

This is the seventh year of a mutli-year project, monitoring the outmigration and survival of juvenile salmonids in the lower Umatilla River. This project both supplements and complements ongoing and completed work within the Umatilla River basin. Knowledge gained on juvenile outmigration and survival assists researchers and managers in adapting hatchery practices, flow enhancement strategies, canal and fish ladder operations, and supplementation and enhancement efforts of natural and restored fish populations. Findings from this study also measure the success of upriver habitat improvement projects and provide an overall evaluation of the Umatilla River fisheries restoration program.

General objectives for 2001 were to: 1) Estimate migrant abundance and survival and determine migration parameters of PIT-tagged hatchery and natural juvenile salmonids; 2) Monitor natural production and estimate overall abundance of pacific lamprey, chinook and coho salmon and summer steelhead; 3) Assess the condition and health of migrants and determine length-frequency distributions through time; 4) Investigate the effects of canal and fishway operations and environmental conditions on fish migration and survival; 5) Investigate and implement improved tag monitoring capabilities; and 6) Participate in planning and coordination activities within the basin and disseminate results.

More specifically, 2001 objectives included the ongoing evaluation of migrant abundance and survival of tagged hatchery fish groups from various species-specific hatchery, rearing, acclimation and release strategies; fourth year reach survival results; continuation of transport evaluation studies; outmigrant monitoring and estimation of natural abundance, and further investigation of the effects of canal operations, environmental factors, fish condition and health on migration, abundance and survival.

Key findings for 2001 revealed: (1) A significant decline in outmigrant abundance of natural salmonids compared with the upward trend of previous years; (2) An undetermined number of hatchery summer steelhead are overwintering in the Umatilla River and migrating out as 2-year old smolts; (3) Transported fish may have a survival advantage over non-transported fish; (4) Migrant survival of fish from the Little White, Carson and Herman Creek hatcheries may have been influenced by disease in 2001; (5) Acclimation may benefit migrant survival of subyearling fall chinook; (6) Overwintering of spring chinook in acclimation ponds may not provide a survival advantage over standard-acclimated fish; and (7) Fish sampled in 2001 tended to be descaled and injured at a higher rate compared with previous years.

\section{Trends observed over the past few years include:}

\section{$>$ Abundance and Survival:}

- Survival of juvenile salmonids increases with decreased river mile of release (reach survival tests).

- Fish released at Bonifer Springs (RM 79) continually display reduced migrant survival over lower river releases.

- Early released fish generally display poorer survival over later released fish. 
- Fish reared in super-oxygenated ponds appear to display improved migrant survival over standard-reared fish. However, this is contrary to smolt-to-adult survival findings.

- Large-grade hatchery summer steelhead have consistently exhibited improved migrant survival over small-grade hatchery steelhead. This is consistent with smolt to adult survival trends.

- The total number of juvenile lamprey emigrating from the Umatilla River continues to be low, however, trapping numbers over the past four years have increased.

$>$ Migration trends are species specific;

- Migration parameters of hatchery summer steelhead appear to be mimicking those of natural steelhead.

- Release strategies (ie. release timing) of hatchery subyearling fall chinook correspond well with the downstream movement of natural subyearling fall chinook (similar migration timing). Both groups generally migrate between May and July.

- Migration timing of natural spring chinook salmon varies from year to year, but generally occurs between March and April. This is consistent with hatchery release timing.

- Further monitoring and investigation is required to clarify migration trends of juvenile coho salmon.

$>$ Environmental conditions may be impacting migrant success and behavior;

- High stream temperatures are potentially reducing the emigration success of natural and hatchery juvenile salmonids

- Stream temperature may be influencing the migration of juvenile salmonids in the Umatilla River by regulating the smoltification process or by acting as a stimulus to initiate downstream movement.

- McKay Reservoir releases appear to be aiding the migration of mid-summer migrants (ie. natural and hatchery subyearling chinook).

Management Implications and Recommendations include: (1) Monitoring of outmigrant abundance of natural salmonids should be continued as a means of estimating natural production, denoting general trends and determining the effect of hatchery releases on natural species; (2) Continue PIT tagging natural salmonids in the upper Umatilla basin. Upstream tagging is one of the simplest and most effective ways of determining origin of migrating smolts (ie. where fish are coming from - mainstem and tributary locations) and estimating outmigrant survival; (3) Closely monitor hatchery summer steelhead overwintering trends in the Umatilla and alter rearing and release strategies, if required; (4) Mark hatchery coho salmon to differentiate natural versus hatchery smolts leaving the system; (5) Refine migrant abundance and survival estimates through movement towards the SURPH model and pursuit of a PIT-tag interrogation system at the east bank fish ladder of Three Mile Falls Dam; (6) Continue water allocations from the McKay Reservoir to maintain minimum flow requirements and suitable stream temperatures for mid-summer migrants. 
Furthermore, specific recommendations for hatchery practices include (a) continuation of subyearling fall chinook acclimation practices and increasing fish size upon release to ensure sufficient smoltification, strengthen imprinting, and potentially improve migrant survival; (b) continue overwintering of hatchery spring chinook at RM 80 (Imeques acclimation facility) to determine the advantages/disadvantages to migrant survival, (c) discontinue use of the Bonifer acclimation site for hatchery summer steelhead.

\section{INTRODUCTION}

Historically the Umatilla River supported large runs of salmon (Oncorhynchus spp.), steelhead (O. mykiss), and Pacific lamprey (Lampetra tridentata) for productive Tribal and recreational fisheries. By the early 1920 s, these runs were decimated. The extirpation and degradation of salmon and steelhead populations in the Umatilla River was a result of extensive agricultural development and associated water withdrawals, habitat destruction, water quality degradation, passage problems, over-harvest and habitat loss both inside and outside the basin (Saul et al. draft 2001).

The Northwest Power Act of 1981 acted as a springboard for focusing attention and effort on restoring these once productive runs, throughout the Columbia River basin. The successive Fish and Wildlife Programs of the Northwest Power Planning Council (NPPC 1984, 1987, 1994) and the Comprehensive Plan for fisheries rehabilitation in the Umatilla River (Boyce 1986) articulated the necessary flow enhancement and fishery rehabilitation efforts required to restore anadromous fish populations in the Umatilla River basin. Efforts included such things as passage improvements at irrigation diversions, habitat restoration, initiation of hatchery production, construction of holding and acclimation facilities, flow enhancement efforts, and fish transport during low flows. Rehabilitation of anadromous fish stocks in the Umatilla River basin called for restoration of spring and fall races of chinook salmon (O. tshawytscha), coho salmon (O. kisutch), pacific lamprey and enhancement of summer steelhead production (CTUIR and ODFW 1989; Close 2002).

Many agencies contributed to the successful implementation of rehabilitation efforts in the Umatilla basin, including the Oregon Department of Fish and Wildlife (ODFW), the U.S. Bureau of Reclamation (USBR), the Bonneville Power Administration (BPA), National Marine Fisheries Service (NMFS), the Oregon Water Resources Department (OWRD), the Confederated Tribes of the Umatilla Indian Reservation (CTUIR), and local irrigation districts (West Extension, Hermiston, Westland, and Stanfield). The Umatilla River Operations Group and the Umatilla Management, Monitoring and Evaluation Oversight Committee (UMMEOC) were created to coordinate river and fisheries management and research in the Umatilla River basin. The Umatilla Hatchery and Umatilla Basin annual operating plan (AOP) was developed to help guide the artificial production programs for the Umatilla River. Furthermore, construction of the subbasin plan (Saul et al. draft 2001) helped define the overall scope and nature of future goals and objectives in Umatilla River basin.

Over the past fifteen years, fisheries restoration efforts have resulted in increasing numbers of juvenile salmonid migrants and adult returns. Artificial production has increased through the 
Umatilla hatchery program and natural production has been enhanced through reintroduction efforts. Improvement in habitat, flows and passage facilities has further bolstered the fisheries restoration effort. Monitoring and research efforts to evaluate these specific restoration and enhancement projects were implemented. These efforts however, did not include an overall evaluation of the migration success and survival of hatchery-reared and naturally-produced juvenile salmonids in the Umatilla River.

Long-term trend monitoring of juvenile abundance and survival was considered valuable as habitat was improved, flow enhanced, natural production expanded, and hatchery practices adjusted. In-basin survival needed to be addressed to answer critical uncertainties in the short term relative to overall survival in the long term. Monitoring and sampling in the lower river was considered crucial for gathering the necessary information regarding life history characteristics, lower river production, abundance, and smolt-to-adult survival of all natural salmonids. Specific questions still remained regarding in-basin survival and passage problems for juvenile fish, production potential for natural stocks, and aquatic community health. Furthermore, as production strategies evolved, results needed to be monitored and merits evaluated to help guide management decisions.

The Outmigration and Survival project was established in 1994 in attempt to address some of the above noted concerns. The project was intended to be long term and broader in scope than previous work, although concerns with juvenile passage at Three Mile Falls Dam still remained and needed to be addressed. Annual changes in environmental conditions, hatchery practices, and research results retained the need for additional information and long term monitoring.

Prior to 1998, outmigration monitoring of juvenile salmonids discerned various hatchery strategies through branded and color-marked fish (Knapp et al. 1996, 1998a, 1998b, 2000). These marking techniques required extensive sampling and fish handling. The advent of PIT-tag technology at John Day Dam in 1998 prompted the use of PIT (Passive Integrated Transponder) tags (400 Khz) in the Umatilla River basin the same year. An upgrade to the $134 \mathrm{Khz}$ system in the mainstem in 2000 , also prompted an upgrade in the Umatilla River. Remote interrogation in the lower Umatilla River provided improved migration, abundance and survival estimates of juvenile salmonids without the stress of handling. Remote detection capabilities also greatly supplemented tag detections at mainstem Columbia dams and provided improved information on in-basin migration parameters.

The overall objective of the Outmigration and Survival Study is to evaluate the outmigration abundance and survival of juvenile salmonids in the lower Umatilla River basin. Furthermore, primary objectives include the identification and monitoring of various factors affecting outmigration and survival for the purpose of facilitating resource management and management direction. Seventh year funding from BPA and third year PIT tag detection data will: 1) Facilitate monitoring of tagged hatchery and natural juvenile salmonids emigrating from the Umatilla basin, 2) Help define migration parameters, abundance, and survival of PIT-tagged hatchery and natural juvenile salmonids in the lower Umatilla River, 3) Clarify the effects of river and canal flow, water temperature, and other environmental variables on fish migration, and 4) Aid in monitoring the movement of juvenile lamprey in the lower Umatilla River. 


\section{STUDY AREA}

The Umatilla River basin is located within Umatilla and Morrow counties, of northeast Oregon (Figure 1). Draining an area of 2,290 square miles, it flows in a northwesterly direction into RM 289 of the Columbia River. The uppermost reaches of the basin are situated along the steep timbered slopes of the Blue Mountains of the Umatilla National Forest (ibid Saul et al. draft, 2001). The remainder of the drainage lies within the broad upland plain of the DeschutesUmatilla Plateau (Contour and Kissner 2000).

The Umatilla River contains a mainstem length of 115 miles (Contour and Kissner 2000) and is fed by eight (8) major tributaries. Elevation ranges from nearly 5,800 feet at the headwaters, to 260 feet at its confluence with the Columbia River (Saul et al., draft 2001). Identified by hydrologic unit number 17070103 (US Geological Survey, 1989), it receives a mean annual precipitation of 10 to $50 \mathrm{in}$./yr within the lower and upper basin, respectively (Contour and Kissner 2000; Saul et al. draft 2001). The Umatilla River subbasin lies within Oregon's North Central bio-geoclimatic zone (Zone 6).

The upper portion of the basin encompasses a section of the Umatilla National Forest as well as 172,000 acres of tribal land (Confederated Tribes of the Umatilla Indian Reservation). The majority of the land in the Umatilla basin is privately owned (82\%), with the remainder being divided amongst the State of Oregon, Umatilla County, various cities and CTUIR (ibid, Saul et al., draft 2001).

Specifically the project area is situated within the lower Umatilla River mainstem, between RM 3.7 and RM 1.2 (Figure 1). The juvenile screening facility (inclined plane trap and PIT tag interrogation system) is located at RM 3.7 within West Extension Canal, immediately downstream of Three Mile Dam. The secondary collection location (rotary screw trap) is situated at RM 1.2 in a deep pool beneath the Interstate 82 bridge. Sampling is conducted year round, with operations focusing at RM 3.7 between March and September and at RM 1.2 from October to February.

Release sites for specific tests (ie. trap efficiency tests, reach survival and trap and haul operations) are located at various points along the Umatilla mainstem. The sites are situated primarily between RM 5 and RM 80. The average monthly discharge within the lower river varies from $23 \mathrm{cfs}$ in summer months (July) to approximately $1095 \mathrm{cfs}$ during spring runoff (April). Water temperatures have been known to peak at sub-lethal levels of $18^{\circ} \mathrm{C}$ to $27^{\circ} \mathrm{C}$ (Saul et al., draft 2001). 


\section{METHODOLOGY}

\section{Outmigration Monitoring}

\section{Trapping and Fish Sampling}

A rotary-screw trap and incline plane trap were utilized to capture emigrating juvenile salmonids in the Umatilla River. The rotary-screw trap, located at RM 1.2, consisted of a 5-ft diameter perforated cone and 12.8- $\mathrm{ft}^{2}$ livebox, supported between two 16-ft long aluminum pontoons. Fish entered the upstream end of the trap and were forced rearward into the livebox by rotation of the perforated cone, which was driven by the water current. The incline plane trap, located at RM 3.7, consisted of diversion screens that directed fish into a bypass channel, through a dewatering plate, and across a fish separator. Large fish $(>400 \mathrm{~mm})$ passed over the separator, into the downwell, and back to the river through a 24 -inch bypass pipe. Small fish $(<$ $400 \mathrm{~mm}$ ) fell through the separator and passed through a PIT tag detection system. Fish were interrogated for PIT tags as they exited the separator back to the downwell. Fish were sampled using a pneumatically actuated gate that was set at timed intervals according to the number of fish moving through the facility. When sampling, fish were diverted into a $100-\mathrm{ft}^{3}$ sample holding tank equipped with a crowder, divider, and lift basket. Fish were crowded into the forward half of the tank and separated from incoming fish by lowering the divider. Fish were held up to 48 hours prior to sampling. Traps were generally checked and cleared of debris once a day, although checks were more frequent during high flow and debris events and less frequent during low flows in late summer and fall (every-other-day).

Groups of five to thirty fish were netted and placed into an aerated static trough or $20 \mathrm{~L}$ bucket for sampling. Fish were anesthetized with a stock solution of MS-222 (40 mg/l) and enumerated by species, race, origin, rear type, and developmental (smoltification) class.

Chinook and coho salmon were categorized as "natural" or "hatchery" based on the presence or absence of an adipose fin, the worn appearance of the dorsal and ventral fins, and size class corresponding to outmigration timing. Steelhead were categorized as "natural" or "hatchery" based on a clipped or unclipped adipose fin (Figure 2).

Fork length was recorded (to nearest $\mathrm{mm}$ ) and single character descriptor codes were used to describe descaling, injuries, parasites, and disease for all juvenile salmonids captured during the sampling period. However, during instances of high fish numbers only 100 to 200 fish were measured and examined. Development (smoltification) class was determined by visible brightness and the absence or presence of parr marks.

All smolts sampled were interrogated for PIT tags and scanned with a tabletop metal detector for the presence of a wire tag. Recaptured PIT tagged smolts were reported to the PTAGIS database.

Data was recorded into the PITTag2 program file using a CalComp Drawing Board III (digitizer). Descriptions of the digitizing unit are included in Knapp et al. 2000. Lengths and 
scales were collected on a subsample of smolted natural summer steelhead, unmarked chinook and coho salmon less than $120 \mathrm{~mm}$, and coho greater than $170 \mathrm{~mm}$ in length for age and origin analysis.

Sample data for each species captured was expanded to account for times when a trap was not sampling. Expansion was determined by dividing the hours sampled by the total number of hours available to sample (i.e. $24 \mathrm{~h} / \mathrm{d}$ ). The average number of hours sampled per day was also calculated. The percent of time spent bypassing fish at the incline plane trap was also calculated.

\section{PIT-Tag Operations}

Passive interrogation (remote detection) with the $134 \mathrm{kHz}$ system at West Extension Canal operated $24 \mathrm{~h}$ /day. Fish entering the canal trap were diverted to a six-inch PVC pipe encircled by two loop antennae. Each antenna was connected to an electronic transceiver unit or reader, (Portable Transceiver System (PTS), Model 2001F); which detected and interpreted codes from previously tagged fish (Figure 3). Once fish passed through the antennae, they were returned to the river via a bypass downwell and pipe extension. Tag data was transferred from the transceiver units to a laptop computer via a serial port hub. Except for the antennae, all electronic systems were housed in a protective plexiglass chamber near the interrogation pipe. The Pacific States Marine Fisheries Commission (PSMFC) Minimon program was used to store tag codes and log system operations. A new interrogation file was created every 4 hours and completed files were automatically uploaded to the PTAGIS database twice daily. The PTAGIS database is operated and maintained by PSMFC in Gladstone, OR.

All fish passing through West Extension Canal and the rotary screw trap during sampling operations were actively interrogated (hand interrogated) for PIT tags. Using the PITTag2 program and a portable transceiver system, anesthetized fish were scanned for tags. Codes from tagged fish were placed in a monitoring file or stored on the reader and downloaded later. A new monitor file was created for each sample period. Fish were placed in a recovery container after interrogation and released into the river once recovered.

Fish of various species, race, and origins were tagged with $134 \mathrm{kHz}$ PIT tags for a variety of purposes and tests. Hatchery fish were tagged for abundance and survival estimates, trap efficiency tests, reach-specific survival tests and transport evaluation studies. Natural fish were tagged for trap efficiency tests and to supplement the Tribal tag database. All tags were obtained from PSMFC.

Prior to tagging, a tagging file was setup on the laptop computer using the PITTag2 program to record codes of implanted tags and track the number of tagged fish. All fish were anesthetized and scanned for tags prior to injection to prevent double tagging. Fish were tagged according to standards outlined in the PIT Tag Marking Procedures Manual (CBFWA, PIT Tag Steering Committee, 1999). Immediately after tagging, newly tagged fish were then scanned to record code data directly in the tagging file. If length data was taken, it was entered into the computer file along with the tag code. Tagging files were submitted to the PTAGIS database on a regular basis. 
Natural fish were PIT tagged in the upper Umatilla River by CTUIR between October 2000 and May 2001. Fish were selected for tagging based on size ( $>75 \mathrm{~mm}$ FL), with the assumption that larger fish were actively migrating. Spring chinook salmon, coho salmon, and summer steelhead were tagged between RM 48 and 80 . Production releases of tagged hatchery fish included yearling spring and fall chinook salmon, subyearling fall chinook salmon, coho salmon, and summer steelhead. These fish were tagged by staff from both the Umatilla Hatchery Monitoring and Evaluation project and the Juvenile Salmonid Outmigration and Survival project and released between RM 56 and 80. Reach survival test fish were released between RM 9 and 79 and transport evaluation test fish were released at RM 27 or transported to the mouth of the Umatilla River.

Tagging and monitoring files were edited and validated through the PITTag2 program and uploaded to the PTAGIS database via email. Interrogation files created in the Minimon program did not need to be edited prior to uploading. Once all tagging, monitoring, and interrogation files were loaded to PTAGIS, the database was queried to determine and compile the original data associated with specific fish detected at WEID or the rotary screw trap.

Tag information was also downloaded from PTAGIS to determine detections of reachspecific survival and transport evaluation fish in the mainstem Columbia River. Mainstem detection sites included John Day and Bonneville dams, the Columbia River estuary, and Columbia River island tag recoveries (predation by birds). All Columbia River detection sites were operating by 9 April 2001.

A temporary remote interrogation system was installed at the east-bank adult fish ladder of Three Mile Falls Dam (TMFD) in May 2001 in an attempt to supplement juvenile tag detections and provide tag information on returning adults (Figure 4). Two 7" portable antennas were taped to the $3 \frac{1}{2} \mathrm{ft}$ by $4 \frac{1}{2} \mathrm{ft}$ glass viewing window. The glass is two inches thick and the fish passage channel behind the window is approximately one foot wide. Each antenna was connected to a PTS Model 2001F reader. Readers were set to store tag codes which were regularly downloaded into a recapture file and uploaded to the PTAGIS database.

Detection capabilities of the temporary setup were tested using a long pole with a test tag attached to the end. The fish passage channel was accessed from above and the test tag was swept through the water channel near the detectors to assess the detection capability. An efficiency test was also conducted using subyearling fall chinook salmon captured at West Extension Canal. Five groups of ten fish each were tagged and held at West Extension canal for 24 hours prior to release. Fish were then hauled in a 350 gal slip tank to the east-bank adult fish ladder of Three Mile Falls Dam and released about 20 feet above the viewing window. Each group of fish was released approximately ten minutes apart into the same location.

The east-bank adult fish ladder detection system at TMFD is slated to receive an interrogation site code TMA (Three Mile Adult) in early 2002. This would enable differentiation of passively interrogated tags detected at the juvenile facility at WEID, TMJ (Three Mile Juvenile), and the adult fish ladder facility (TMA). 


\section{Trap Efficiencies}

Trap efficiency tests for juvenile salmonids were conducted at West Extension Canal (RM 3.7) between 12 March and 30 June 2001. Tests were conducted to ascertain the detection efficiency of the trap facility during various operational and environmental conditions. Hatchery and natural PIT-tagged fish were used for tests and tests were species specific. Trap collection efficiencies were used to expand the detections of tagged fish and the number collected for untagged fish for an estimate of migrant abundance.

Only healthy fish were collected from the sampling facility at West Extension Canal for use in trap efficiency tests. Whenever possible, unclipped and non-wire tagged hatchery fish were used. Fish collected for trap efficiency tests were held in net pens until sufficient fish $(50-150)$ were available to conduct the test. Net pens were held in a large circular tank supplied with inflow water from the canal; fish were tagged at a station adjacent to the holding tanks. Test fish included yearling spring, fall, and subyearling fall chinook salmon of hatchery origin, coho salmon of unknown origin, natural chinook salmon and hatchery and natural summer steelhead.

Tests were generally conducted two times per week for each species and race of fish while sufficient numbers were being captured. Fish were tagged with $134 \mathrm{kHz}$ PIT tags and codes were scanned directly into a PITTag2 tagging file on a laptop computer. A new tagging file was created for each test and species. After tagging, fish were held in special net pens within circular tanks for $24 \mathrm{~h}$ to assess latent mortality (tagging effect) and loss of tags. These special net pens incorporated a large-meshed false bottom, which allowed dropped tags to fall through to the small-meshed bottom of the pen where they were safe from fish consumption. Water temperature was recorded at the start and end of holding. Dropped tags and mortalities were collected, counted, and scanned at the end of the holding period. If a dead fish did not have a tag, a dropped tag was attributed to that fish. The number of fish that died during the 24-h holding period was used to assess the probability of survival $(s)$ of remaining fish released for each test. Probability of survival was determined by dividing the number of live fish after holding by the number of fish held.

Tagged fish were transported to the release site at the Wastewater Treatment Plant (RM 5.0) in an un-insulated, aerated, 300-gal slip tank. Releases were generally made in late afternoon or early evening to avoid mid day temperatures and reduce potential mortality. Transport mortalities were retained and scanned for tag codes. Fish were released via a flex hose attached to the slip tank and a 10-in PVC pipe leading to the river. River temperature was recorded at the time of release.

All codes from dropped tags and mortalities were removed from the tagging file. A total count of dropped tags was used to determine percent tag retention. Tag retention was assumed to be $100 \%$ after release and was not used in adjusting the trap efficiency estimate. All dropped tags and mortalities were accounted for when determining the total number of tagged fish released for each test. The final release number $(N)$ was then adjusted for expected survival $(s)$ to obtain the adjusted number of tagged fish available for detection $(M ; N(s)=M)$. After release, survival was assumed to be $100 \%$ for all factors other than tagging effect. 
Trap efficiency test fish were detected at West Extension Canal via the remote detection system or hand sampling (see PIT-Tag Operations). Reports were downloaded from the PTAGIS database on a regular basis to determine the number of fish detected from each trap efficiency release group.

Trap efficiency estimates (TE) were determined based off the number of test fish detected $(R)$ at West Extension Canal from each test group out of the adjusted number of tagged fish released upstream of the trap $(M ; T E=R / M)$. Separate trap efficiencies within a species were compared using $\mathrm{Chi}^{2}$ analysis and pooled if the efficiency estimates were not significantly different at an alpha level of 0.05 . If detections were $<5$, test data was combined with an adjacent test until the detection sample size was $\geq 5$ to satisfy the limitations of the $\mathrm{Chi}^{2}$ test. Pooling was continued until a significant difference was determined. The final trap efficiency estimate was the weighted mean of the pooled estimates. Singular or pooled efficiency estimates were used to determine abundance of tagged fish (see Abundance and Survival).

\section{Migration Parameters}

Migration parameters were analyzed for production fish, reach-specific survival test fish, and natural fish. PIT tag detections were used to determine dates of peak movement, median travel speed, and migration pattern, timing, and duration. Migration patterns and periods of peak movement were identified from a plot of daily detections through time. Migration duration was

the length of time from initial to final detection. Median detection was the $50^{\text {th }}$ percentile detection. Individual travel speed ( $\mathrm{mi} / \mathrm{d})$ was estimated by dividing the miles from release site to detection site by travel time (days; based on forced release date). Median travel speed was calculated from all fish detected through the remote interrogation system. Diel movement of PIT-tagged fish was determined by percentage of fish detected through the remote interrogation system within hourly blocks of time.

Travel time to John Day and Bonneville dams on the lower Columbia River was determined for reach-survival test fish. Tag recoveries from fish consumed by terns or gulls nesting on islands in the mainstem Columbia were also documented.

\section{Length Analysis}

Fork length (FL) was measured to the nearest millimeter ( $\mathrm{mm}$ ) for all natural salmonids and a portion of hatchery salmonids sampled at West Extension Canal. All PIT tagged fish encountered in hand samples were measured to assess growth from tag date to recapture date. During tagging of reach-specific survival fish, fork length was measured on about 100 fish per group. Length data was used to create length-frequency distributions on a monthly basis for all species and races and to distinguish between natural races. 


\section{Fish Condition and Health}

All fish were examined for descaling, body injuries, parasites, and diseases. Descaling was categorized following criteria used by the Umatilla Hatchery Monitoring and Evaluation project (Keefe et al. 1994). Fish health was considered "good" if cumulative scale loss on either side of the fish was less than 3\%. Fish were considered "partially descaled" if cumulative scale loss was greater than $3 \%$ but less than $20 \%$. Fish with scale loss greater than $20 \%$ were considered "descaled". Single character descriptor codes were used to describe injuries, parasites, and disease for all juvenile salmonids. Symmetrical bruises on each side of the fish were classified as bird marks.

Fish mortalities were noted by species and identified as pre or post sampling. Percent sampling mortality and natural mortality were estimated separately. Percent mortality (either type) was determined from the total number of fish sampled, not just examined. All dead natural fish and some diseased and dead hatchery fish were examined by the ODFW Fish Pathology Lab to determine fish health status. Unusual marks or indications of disease on dead fish were also noted.

\section{Lamprey Monitoring}

Pacific lamprey were captured at both the rotary-screw trap and incline plane trap throughout the sampling season. Total length (nearest $\mathrm{mm}$ ) was recorded and developmental stage was classified by coloration and the presence or absence of eyes and a mouth. Larvae were identified as being brown in color with no eyes or a mouth. Macrophothalmia were silvery in color and had developed eyes and a mouth. Lamprey larger than $200 \mathrm{~mm}$ with eyes and a mouth were considered adults.

Trap efficiency tests utilizing macrophothalmia were performed at the rotary-screw trap. Fish were marked with a small caudal fin clip $(1-2 \mathrm{~mm})$ and held in a perforated bucket (in river) for 24 to 48 hours. Mortalities were removed and counted prior to transport to release site. The release site was located approximately a quarter mile upstream (RM 1.5).

Length-frequency distributions by calendar quarter and calculated overall mean lengths for larvae and macrophotalmia were determined. In addition, river flow $\left(\mathrm{ft}^{3} / \mathrm{s}\right)$ at $\mathrm{RM} 2.1$ and the number of lamprey captured was plotted against time and correlation analysis was utilized to determine a linear relationship. 


\section{Abundance and Survival}

\section{Migrant Abundance and Survival}

Migrant abundance and survival was estimated for various species and race of juvenile salmonids, including PIT-tagged and non-tagged fish of both hatchery and natural origin. Abundance $^{1}$ of PIT-tagged fish was estimated based on detections (tag) at West Extension Canal. Fish from tagged groups symbolized various hatchery, rearing, acclimation, and release strategies and were considered 'representative' of fish from non-tagged groups. Total abundance $^{2}$ of natural fish emigrating past RM 3.7 was also estimated, based on species collection. Migrant abundance of natural salmonids was estimated in order to supplement tribal data and aid in monitoring of population abundance, production and smolt-to-adult survival of natural fish in the system.

\section{Abundance}

Abundance $^{1}$ of tagged fish groups was estimated based on the migrant abundance method (Dauble et al. 1993). Migrant abundance $(A)$ of individual fish groups was calculated using the number of tag detections (D) and corresponding trap efficiency $(T E)$ estimates $[A=(D)(1 / T E)$; Burham et al. 1987; Dauble et al. 1993]. Since detections were date specific, efficiency estimates used, encompassed corresponding tag dates. If efficiency estimates did not correspond to the dates tags were detected, trap efficiency data was arbitrarily pooled using the closest daily estimates before and after the detection date.

Abundance estimates for individual groups (or strategies) were summed, to obtain a total abundance of PIT-tagged fish by species, over the entire collection period. The Bootstrap method (Efron and Tibshirani 1986; Thedinga et al. 1994) was used with 1,000 iterations to determine a variance for each abundance estimate. Variances for abundance subtotals were summed to derive an overall variance. Confidence intervals (95\%) for the abundance estimate were calculated using the square root of the variance $(\mathrm{CI}=1.96 \sqrt{\mathrm{V}})$.

Migrant abundance ${ }^{2}$ of natural species was estimated based on collection of tagged and nontagged fish at West Extension Canal and the rotary screw trap. Natural species collected included steelhead, coho and chinook salmon. Total abundance of natural fish was determined by relying on several expansion factors to extrapolate for missing data. The number of natural fish sampled was expanded by the sampling rate, $\%$ sample time, diel, trap efficiencies and retention efficiencies to predict the overall number of juvenile fish leaving the system. Total abundance of each species was estimated on a monthly basis, and then summed for the entire season.

Expansion factors used to calculate natural abundance at West Extension Canal and the rotary screw trap differed, due to the differing nature of the facilities and variations in sampling at each trap. Sampling at West Extension Canal was irregular and varied from month to month based on fish movement. The number of fish collected at West Extension Canal was thus, expanded by the sample rate for the particular sampling period $(C)$. This $(C)$, was then adjusted by the proportion of time sampled $(T)$, within a primary block of time to account for unsampled

${ }_{1}^{1}$ Abundance $=$ total number of tagged fish for a particular release group or strategy.

${ }^{2}$ Abundance $=$ the overall number of natural fish leaving the system. 
hours within the block. The diel pattern of fish movement through the facility based off tag detections, was then used to determine the proportion of fish detected within the defined block $(D)$. This proportion was then used to make a final adjustment for the number of fish passing through the facility $(B=(C / T) / D)$. Total fish passage was derived by expanding the number of fish bypassed $(B)$ by the average trap efficiency $(T E)(A=B / T E)$. For months where trap efficiencies of natural species were not available or were sparse, efficiency estimates from hatchery conspecifics were used to supplement the average estimate. If hatchery conspecifics were not available for a particular month, efficiency estimates from the month before or month after were used.

Natural abundance (A) at the rotary screw trap was estimated by adjusting the number of fish collected (C) by the trap retention efficiency (TR) and the trap efficiency (TE) estimate $[\mathrm{A}=(\mathrm{C} / \mathrm{TR}) / \mathrm{TE}]$. Sampling rate and time were not adjusted for due to $24 \mathrm{hr}$ a day trap operation. Trap efficiency estimates for coho and chinook salmon were derived from 1997 and 1998 tests (Knapp et al. 1998; Knapp et al. 2000). Natural chinook salmon were assumed to be $100 \%$ retained in the trap due to their small size. Since retention efficiency estimates were not available for natural or hatchery steelhead, a $50 \%$ retention efficiency was assumed, based on a $77 \%$ efficiency estimate for hatchery spring chinook (Knapp et al. 2000). Similarly, since trap efficiency estimates were also not available for natural or hatchery steelhead, a trap efficiency estimate of $1 \%$ was applied, assuming the efficiency for natural summer steelhead would be around half that of yearling spring and fall chinook salmon (2.1 - 3.7\%; Knapp et al. 2000) due to their ability to avoid the trap (determined from sampling in 1997; Knapp et al. 1998b).

\section{Survival}

Survival $(\mathrm{S}=\mathrm{A} / \mathrm{R})$ of natural and hatchery PIT tagged fish was also determined using the migrant abundance method (Burham et al. 1987; Dauble et al. 1993). Survival $(S)$ was defined as the proportion of tagged migrants passing the sampling site (Abundance $=A$ ) to the number of tagged fish released at upriver sites $(R)$. The binomial test was used to test for significant differences in detection between production release groups.

Migrant survival of different hatchery, rearing, acclimation and release strategies was compared for each species of hatchery tagged fish (Table 1). Comparisons included the volitional and forced release of all species, monitoring of optimal rearing strategies for spring chinook (super-oxygenated vs standard raceways) and summer steelhead (large-grade vs. smallgrade), refinement of ponding and acclimation techniques for spring and subyearling fall chinook (none, some, or overwintering), and evaluation of optimal coho and spring chinook salmon rearing locations, as well as release sites and tactics for all species (early vs. late and direct vs. acclimated).

\section{Reach-Specific Survival}

Reach-specific survival tests were conducted for large and small-grade summer steelhead. Fish were released at three lower river locations (RM 9, RM 27, and RM 48), in addition to the standard release site at the respective acclimation facilities (RM 65 and 79). Each test group was held separately in indoor circular tanks at the hatchery until time of release; test fish were thus not acclimated prior to release. Mortality was recorded on a daily basis and tag loss was 
determined at the end of holding. Tag consumption was eliminated by fastening false bottoms to the tank.

Survival tests included five groups of large-grade summer steelhead (194 - 401 fish/group) and four groups of small-grade summer steelhead (401-495 fish/group). Releases were spread over three consecutive days (replicates), and began on the same day as production releases from the acclimation facility. On the day of release, fish were netted into site-specific 30-gal containers with lids and transported in an aerated 300-gal slip tank to each release site. Fish were released either by hauling the entire container down to the river or by attaching the flex hose and releasing fish directly into the river.

Fish were interrogated in the lower river either through remote detection or hand sampling at West Extension Canal. Fish were also interrogated at mainstem dams, in the estuary, and thru recovery from bird island colonies. Interrogation reports were obtained from the PTAGIS database to determine the derivation of all tag detections. Duplicate tags (detected at more than one location) were converted to a singular detection and ascribed to the uppermost site. It was assumed that fish detected at mainstem locations had survived and exited the Umatilla River basin.

Reach-specific survival was estimated using several different methods. The migrant abundance method (as described in Migrant Abundance and Survival) was used to derive survival estimates for each replicate release and a mean survival estimate for each reach. Significant differences in survival among sites were determined using ANOVA with transformed data (arc-sine), followed by Duncans multiple comparison test when ANOVA results were significant. A relative survival index (mean percent detection for each release site) was derived using non-duplicative tag detections within the Umatilla and Columbia rivers, including tag recoveries from islands with bird colonies. Confidence intervals $(95 \%)$ were computed from standard deviation of the means.

\section{Transport Evaluation}

Transport evaluation (trap and haul) was conducted with hatchery subyearling fall chinook salmon from Westland Canal (RM 27) between late June and mid-July. Transported (treatment) fish groups were hauled to the mouth of the river and released and non-transported (control) groups were released directly to the river at Westland Canal. Tests were conducted to determine relative survival of transported versus non-transported fish.

Approximately 2,600 subyearling fall chinook salmon were PIT-tagged and held at the Irrigon hatchery in indoor circular tanks $\left(12^{\circ} \mathrm{C}\right)$ for 16-30 days. Two separate groups of 1,300 fish each were then transferred from the hatchery to Westland Canal. The holding tank at Westland Canal was supplied with river water to acclimate fish to ambient water temperatures (13 to $21^{\circ} \mathrm{C}$. Both transported and non-transported fish were acclimated for three to ten days prior to release.

Non-transported fish were transferred from the hatchery to Westland Canal in late June. Five groups of approximately 250 fish each were released directly into the river just below 
Westland Dam. Releases were made every other day and water temperature was recorded at the time of release.

Four groups of 233 to 439 fish each were transported from Westland Canal to the mouth of the Umatilla River in early July. On the day of transport, fish were placed into the holding pond before crowding and a subsample was taken by CTUIR for species composition data. Treatment fish handled in the subsample were noted and tag codes were deleted from test files. Once the subsample was taken, fish remaining in the holding pond (tagged and untagged) were transferred to a transport tanker and hauled to the mouth of the Umatilla River. Releases were made every other day except for the last release, which was made 3 days after the previous release. Tag detections from transported and non-transported fish were downloaded from the PTAGIS database and survival indices compared.

\section{Environmental Conditions and Bypass Operations}

Physical and environmental conditions at both trapping sites were monitored throughout the season to characterize conditions in the Umatilla River and to assess their effects on fish migration. Variables at RM 1.2 included air and water temperature $\left({ }^{\circ} \mathrm{C}\right)$, debris level, turbidity, and river elevation. Measurements were recorded daily, usually in the afternoon.

At RM 3.7, air and water temperature $\left({ }^{\circ} \mathrm{C}\right)$, turbidity, debris level, river and canal elevation, and bypass operations were recorded. Bypass operations included the operation or non-operation of three pumpback pumps, setting of three canal headgates, and the amount of water being returned to the river by the trapping facility. River and canal elevations and debris level were noted several times a day, while all other observations were recorded once daily at or near 1200 hours. The operation of Phase I pump exchange was also noted on a daily basis.

Daily maximum and minimum water and air temperatures were measured using a Taylor ${ }^{\circledR}$ Max-Min thermometer. Debris level was categorized as low, moderate, or high. Turbidity was measured to the nearest $0.05 \mathrm{~m}$ using a 7-in-diameter Secchi disk. Secchi depth was determined by averaging the depth at which the disk disappeared and reappeared as it was lowered and then raised from the water. At RM 1.2, river elevation was recorded to the nearest 0.5 inch using a staff gauge attached to a bridge piling. At RM 3.7, a staff gauge located upstream of the canal headgates was utilized to measure river elevation and a staff gauge downstream of the canal headgates was used to measure canal elevation. Both were recorded to the nearest $0.10 \mathrm{ft}$.

River, canal, Phase I, and McKay Reservoir release flow data $\left(\mathrm{ft}^{3} / \mathrm{s}\right)$ was obtained from U.S. Bureau of Reclamation gauging stations. River gauging stations are located at RM 2.1 (UMAO), RM 8.5 (UBBO), RM 24.4 (UMDO), RM 28.3 (UMUO), RM 37.6 (YOKO), RM 52.0 (MCKO), and RM 55.3 (PDTO). The canal gauging station (WEIO) is located near the town of Umatilla. The Phase I gauging station (WEPO) measures flows being added to the West Extension Canal from the Columbia River.

Daily canal flow was calculated by subtracting Phase I exchange amount from canal flow, and then adjusting for fish bypass operations. Daily river flow for RM 3.7 was calculated by adding the RM 2.1 gauge reading and the daily canal flow. 
Daily water temperature data used for statistical comparisons was obtained from a CTUIR thermograph located at RM 3.7. Missing values were estimated by taking the average of the daily water temperature three days prior and three days after the missing value.

Daily flow index $\left(\mathrm{ft}^{3} / \mathrm{s} / 100\right)$, mean water temperature, and percent detection (RM 3.7) of each species/rear type was plotted against time. Correlation analysis was used to determine a linear relationship between percent detection and mean daily river flow and water temperature. Additionally, river flow, change in river flow in relation to the previous day, and water temperature were evaluated by calculating the percentages of the observed PIT tag detections that occurred in a given range for each environmental category. The analysis was based on the null hypothesis; the percentage of PIT tag detections within each category range would not differ from the percentage of the total Pit tag detection period within each environmental category range. Deviations from the null hypothesis were tested using the $X^{2}$ goodness-of-fit test.

Travel speeds (mi/d) from various release sites within the Umatilla Basin to RM 3.7 were determined using PIT-tagged fish. Correlation analysis was used to evaluate relationships between travel speed and river flow. Daily river flow data from gauging stations in close proximity to release locations were used to calculate the mean river flow for specific river corridors encountered by release groups.

Correlation analysis was also used to evaluate relationships between canal operations and fish behavior and McKay Reservoir releases. Associations were made between daily canal diversion rate and daily trapping efficiencies, daily river flow and trapping efficiencies, and daily McKay Reservoir releases and percent detection. Daily canal diversion rate was calculated by dividing the daily canal flow by the daily river flow.

\section{RESULTS}

\section{Outmigration Monitoring}

\section{Trapping and Fish Sampling}

The rotary-screw trap (RM 1.2) operated from 2 October 2000 through 8 March 2001. A total of 46 juvenile salmonids were sampled during the season. The adjusted sample was 129 juvenile salmonids (Table 2). Natural chinook salmon accounted for $56.6 \%$ of the adjusted sample, natural coho $34.9 \%$, hatchery spring chinook salmon $6.2 \%$, hatchery chinook salmon $1.5 \%$, and natural summer steelhead $0.8 \%$. Sampling peaked on 8 October 2000 and again on 23 January 2001 with a total of 17 fish. All fish observed in the trap in October were natural coho and all fish captured in January were natural chinook salmon (Figure 5). Natural chinook salmon were captured throughout the sampling period and natural coho between 6 October and 7 January. Hatchery chinook salmon were captured on 11 November and 20 February and natural summer steelhead on 9 February. Hatchery spring chinook salmon were captured on 3 March and 7 March, with the first fish being captured 2 days after a release from the Imeques acclimation pond.

The incline plane trap (RM 3.7) operated from 9 March 2001 through 28 September 2001. The trap did not operate 10 July through 19 August and again from 30 August to 16 September 
due to low flows and debris problems. A total of 33,847 juvenile salmonids were sampled during the monitoring season (Table 2). This is similar to the 2000 season, in which 34,800 juvenile salmonids were sampled. The adjusted sample total was 42,338 juvenile salmonids, which is significantly lower than the 2000 total of 109,529 fish. Forty seven percent of the adjusted sample was coho salmon of unknown origin, hatchery yearling fall chinook salmon $11.5 \%$, hatchery subyearling fall chinook salmon $10.4 \%$, hatchery spring chinook salmon $8.5 \%$, hatchery summer steelhead $6.8 \%$, natural chinook salmon $4.3 \%$, hatchery chinook salmon $4.2 \%$, hatchery coho $3.2 \%$, natural summer steelhead $2.6 \%$, and natural coho $0.6 \%$. The sampling peaked during the week of 4 May to 10 May 2001. A total of 11,595 fish were sampled. Coho of unknown origin comprised $78.5 \%$ of the weekly total and hatchery yearling fall chinook salmon comprised $11.3 \%$ (Figures $6 \& 7$ ). Peak sample dates for all other species were: hatchery spring chinook salmon (27 April to 3 May), hatchery subyearling chinook salmon (25 May to 31 May), hatchery chinook salmon (4 May to 10 May), hatchery coho (4 May to 10 May), hatchery summer steelhead (6 April to 12 April), natural chinook salmon (22 June to 28 June), natural coho (24 May to 31 May), and natural summer steelhead (25 May to 31 May). Over $99 \%$ of the fish were sampled at RM 3.7 by the first week in July (29 June to 5 July).

The incline trap operated 1,869 hours for an average of $10.5 \mathrm{~h} / \mathrm{d}$ during the 2001 monitoring season. One hundred percent sampling began on 11 June and continued until the facility was dewatered in late September. When utilized, the rotary-screw trap was operated continuously except during trap checks. Overall, the combined total sample hours were 4,245 , or $48.7 \%$ of the monitoring period.

Four adult salmonids were captured at RM 1.2 in 2001. One dead unclipped fall chinook salmon minijack, 2 unclipped fall chinook salmon, and 1 natural steelhead. No adult salmonids were captured at RM 3.7.

\section{PIT-Tag Operations}

The $134 \mathrm{kHz}$ remote interrogation system installed at West Extension Canal worked well throughout the season. Improvements for 2001 included remote access to the field site computer with PC Anywhere software, and auto upload of the remote interrogation files to the PTAGIS database. The computer system unintentionally shutdown on 8 May due to power save settings. These settings were changed and no further shutdown instances occurred. The readers were set to store codes so detections were not missed when the computer shutdown. Despite cooling efforts, over heating of readers was a problem once again this year. One reader required servicing and repair by mid-April.

Of the fish detected at West Extension Canal (both hatchery and natural), 91\% were interrogated through the remote detection system. The remaining $9 \%$ were interrogated through hand sampling. No tagged fish were detected at the rotary trap and fish sampled at Westland Canal were not scanned for tags.

Eight codes were detected at West Extension Canal with no associated tag file and were considered orphans in the PTAGIS database. Four of these codes were from large-grade steelhead and three from small-grade steelhead released for reach-specific survival tests. Specific release groups could not be determined for these orphaned codes. 
Hatchery species detected at RM 3.7 included yearling spring and fall chinook, subyearling fall chinook salmon, coho salmon, and summer steelhead (Table 3). Significant difference in detection was not evident between acclimated and direct stream released fish. Rearing hatchery for spring chinook salmon appeared to be an important factor in relative detection. Percent detections for subyearling fall chinook salmon were highest of all species $(34.8-48.5 \%)$.

Detections of hatchery spring chinook salmon reared at the Umatilla Fish Hatchery were greater than all other groups of spring chinook released (Little White Salmon and Carson Fish Hatcheries). Percent detection for yearling fall chinook salmon released in April was about 5 times higher than March released fish. Tagged coho released in March were detected 2-6 times less than fish released in April, regardless of hatchery origin. The lowest percent detection for summer steelhead was from the group of small-grade fish tagged and released early with largegrade fish at RM 79 (4.9\%).

Natural species detected at RM 3.7 included chinook and coho salmon, and summer steelhead (Table 4). The majority of chinook salmon detections were from fish tagged in the Umatilla River mainstem and from fish tagged later in the migration season (February and March). Similarly, detections were highest amongst summer steelhead tagged in the Umatilla mainstem, with the majority of detections being from fish released in March and April. The number of coho salmon tagged was low (251 fish), hence low detections were obtained.

The temporary detection system at the east-bank fish ladder viewing window of Three Mile Falls Dam operated between 26 May 2001 and 30 September 2001. One hundred and forty five juvenile fish were detected in the 2001 migration season using the temporary setup. This included natural production, hatchery production, reach-specific survival, and trap efficiency fish. Because of late season installation, detection efficiency tests for the temporary system were conducted for subyearling fall chinook salmon only (4.0\% efficiency).

\section{Trap Efficiencies}

Hatchery fish tagged for trap efficiency tests included 746 spring chinook salmon, 716 fall chinook salmon, 547 subyearling fall chinook salmon, and 659 summer steelhead. In addition, 756 coho salmon of unknown origin, 352 natural chinook salmon and 284 natural summer steelhead were tagged. Percent holding survival and tag retention were greater than $96 \%$ for all species except natural and hatchery summer steelhead tagged on 25 May 2001 (Table 5). Water temperature in the holding tanks increased to $23^{\circ} \mathrm{C}$ during this day, contributing to increased mortality $(13.2 \%)$.

Significant differences were found among daily trap efficiency estimates for all fish groups, except natural chinook salmon. Mean pooled estimates of trap efficiency data ranged between $6.3-30.9 \%$ for both natural and hatchery fish (Table 6). The lowest trap efficiencies were from natural chinook salmon. Seven to ten releases were made for each species. Most test fish were detected within 2 days of release and $90 \%$ of all fish were detected within 5 days of release. Coho salmon released in late March and early April had the slowest mean travel time of all species. 


\section{Migration Parameters}

Production Fish: Peak detections of Umatilla hatchery spring chinook salmon occurred two days after the forced release (Table 7; Figure 8). No peak date was discernable for fish from Little White and Carson National fish hatcheries. Median travel speeds for fish released in March were 3 to $5 \frac{1}{2}$ times faster than for fish released in April. Detection duration was shorter for April-released fish than March-released fish. No clear pattern emerged for diel movement in hatchery spring chinook salmon, however fewer fish moved in March during mid-day (1000 to 1500 hours; Figure 9).

Fall chinook salmon released in April peaked one week after the force release date (Table 7; Figure 10). No peak detection was discernable for March-released fish. Median travel speed of fall chinook released in March was $3 \frac{1}{2}$ times slower and was 13 days longer in duration than fish released in April. The majority of hatchery fall chinook moved between sunrise and sunset (Figure 11).

Peak detection for all tag groups of subyearling fall chinook salmon was within 3 days of the force release (Table 7; Figure 10). Median travel speed was similar for all groups except the direct stream release on 25 May 2002, which was slower. Duration of detection was short for all groups, lasting an average of 19 days. Similar to yearling fall chinook salmon, hatchery subyearlings primarily moved between sunrise and sunset (Figure 11).

Migration parameters of coho salmon were similar for March and April released fish. A peak was not discernable for the March released groups because of low detections (Table 7; Figure 12). Most diel movement of coho salmon was between sunrise and sunset (Figure 11)

Large and small-grade hatchery summer steelhead exhibited similar migration patterns despite differing release sites and dates (Table 7; Figure 12). All tag groups peaked in late May about 1 to $1 \frac{1}{2}$ months after release. Median detection date for large-grade fish released at Minthorn (RM 64.5) in early April was $2 \frac{1}{2}$ to 3 weeks earlier than other groups. Detection duration and travel speed were similar for all release groups (53-66 d and 1.6-2.9 mi/d) except small-grade fish released in late-April ( $44 \mathrm{~d}$ and $3.6 \mathrm{mi} / \mathrm{d}$ ). The majority of hatchery steelhead moved between sunrise and sunset (Figure 13).

Reach Survival Fish: Large and small-grade summer steelhead tagged for reach-survival tests were released from 3-5 April and 25-27 April, respectively. Detection of large-grade fish peaked in early April, one to six days after release (Table 8). Median detection dates and travel speeds were later and slower for upper released fish (RM 48, 64.5, and 79) over lower released fish (RM 27 and 9). Detection of small-grade summer steelhead from lower (RM 9 and RM 27) and upper release sites (RM 64.5) generally peaked in late April and May, respectively. Travel speeds were similar for all releases of small-grade fish (1.7-3.7 mi/d), with the exception of smalls released at RM 9 on 25 May $(0.9 \mathrm{mi} / \mathrm{d})$. Travel speed among release sites for largegrade summer steelhead was more variable within the Umatilla River $(2.2-14.9 \mathrm{mi} / \mathrm{d})$ particularly when compared to travel within the Columbia River mainstem $(2.2-5.1 \mathrm{mi} / \mathrm{d}$; Table 8). 
Natural Fish: Tagging of natural fish by CTUIR began in late October 2000 and continued until May 2001. Ninety-six percent of the natural chinook detected were tagged in the mainstem Umatilla River. Natural chinook salmon detections peaked on 27 April 2001 and travel speeds were much slower than their hatchery counterparts (Table 7; Figure 8). Of the 251 natural coho salmon tagged in the mainstem Umatilla River, only 3 were detected at RM 3.7. These fish were tagged in November and December of 2000 and subsequently detected between the 26 April and 13 May 2001 (Table 7). Peak detection of natural summer steelhead occurred in late May (Table 7; Figure 13). Natural summer steelhead migrated out sporadically from March until June. Travel speed was fastest and detection duration longest for fish tagged and released in the Umatilla River mainstem. Diel patterns of natural fish varied minimally from their hatchery counterparts. In March, the majority of fish movement occurred at night (Figure 14).

Emigration occurred around the clock in April, with no prime pattern emerging. In May, the majority of fish movement occurred between sunrise and sunset.

\section{Length Analysis}

Length frequency distributions of natural and hatchery juvenile salmonids are presented in Figures 15 to 18. Mean fork length of hatchery spring chinook and chinook salmon of unknown race were between 141-153 mm (March to May). Mean lengths for fall chinook salmon were slightly larger for the same time period (157 - $164 \mathrm{~mm}$ FL; Figure 15). Not included in the figures are five large juvenile chinook salmon (221 - $275 \mathrm{~mm}$ FL, possibly mini jacks) collected in March and April.

Hatchery subyearling fall chinook salmon had similar distributions in May and June, with mean fork lengths ranging from 100 - $105 \mathrm{~mm}$ FL (Figure 16). Few fish were seen during the month of July and length distribution was more spread out. Some growth was apparent however during mid-summer months, with peak mean lengths ranging from $105-135 \mathrm{~mm}$ FL.

Length differentiation between natural yearling and subyearling chinook salmon was possible in May; two different age classes of fish were apparent (Figures 15 and 16). Smallersized fish ( $80-90 \mathrm{~mm}$ FL) were collected in May, signifying the subyearling life stage, whereas fish collected in April neared $105 \mathrm{~mm}$ in length. By June and July, most natural chinook salmon captured were between 65 - $95 \mathrm{~mm}$ FL, signifying subyearling chinook of both spring and fall races. Considerable growth of subyearling chinook salmon was evident by September (115 mm modal FL).

Mean fork length of marked (adipose-fin clipped) coho salmon increased monthly, to a maximum fork length of $160 \mathrm{~mm}$ by May (Figure 17). Unmarked coho (fish of both hatchery and natural origin) had similar monthly distributions as marked fish, suggesting they may be of hatchery origin (Figure 17). The most common lengths of unmarked coho salmon increased from $155 \mathrm{~mm}$ in May to $175 \mathrm{~mm}$ in June. The length-frequency distributions from March to May indicate the yearling life stage. Length-frequency data indicates fish migrating in June were likely of both hatchery and natural origin.

Mean fork length of hatchery summer steelhead ranged between 180 - $290 \mathrm{~mm}$ compared with $110-225 \mathrm{~mm}$ for natural counterparts. Fork lengths for hatchery summer steelhead in April and May were about $37 \mathrm{~mm}$ and $46 \mathrm{~mm}$ larger respectively, than mean fork lengths for 
natural steelhead during the same time period (Figure 18). Length distribution of hatchery and natural steelhead was more variable in June.

\section{Fish Condition and Health}

A total of 14,829 juvenile salmonids were examined for descaling, body injuries, parasites, and diseases $(8,180$ hatchery, 2,444 natural, and 4,205 unknown coho). The overall descaling rate was $3.6 \%$ in 2001, in comparison to $1.5 \%$ in 2000 (Table 9). Individual descaling rates for all species/rear types, except natural coho were higher this season than in 2000. Hatchery summer steelhead exhibited the highest descaling rate $8.0 \%$. This was significantly higher than the $3.7 \%$ observed in 2000 . Total descaling was not correlated with river flows $(r=0.094)$, turbidity $(r=0.059)$, or water temperature $(r=0.072)$.

Bird marks were present on $4.0 \%$ of the fish examined during the 2001 sampling period (Table 10). This was higher than the $2.7 \%$ observed in 2000 . The presence of bird marks was $5.0 \%$ for hatchery fish, $1.7 \%$ for natural fish, and $3.6 \%$ for coho of unknown origin. Hatchery summer steelhead exhibited the highest percent of bird marks (7.9\%). The overall body injury rate for 2001 was $3.4 \%$, which was $46.7 \%$ higher than observed in 2000 . Hatchery fish were injured at a rate of $4.0 \%$, natural fish $2.9 \%$, and coho of unknown origin $2.6 \%$. Hatchery spring chinook salmon exhibited the highest rate of injury at $6.4 \%$. External parasites were present on $1.4 \%$ of all fish examined. This was higher than the $0.9 \%$ observed in 2000 . Natural fish were infested with parasites at a rate of $4.9 \%$, hatchery fish $0.9 \%$, and coho of unknown origin $0.6 \%$. Natural summer steelhead exhibited the highest presence of external parasites (7.4\%) (Table 10).

\section{Lamprey Monitoring}

Juvenile lamprey, macrophothalmia and larvae, were captured at RM 1.2 and RM 3.7 between December 2000 and May 2001. The first fish was observed on 22 December 2000 at RM 1.2 and the last was observed 1 May 2001 at RM 3.7. Seventy three percent of all juvenile lamprey were captured at RM 1.2 during a two-day period (6 and 7 February 2001) with macrophothalmia dominating the sample $(82 \%)$. The daily number of juvenile lamprey captured at RM 1.2 were positively correlated with flow, however, no relationship was evident at RM 3.7 (Figure 19; Table 11).

The average length of larvae captured at RM 1.2 was $157.0 \mathrm{~mm}$. Macrophothalmia averaged $152 \mathrm{~mm}$. A similar size difference was observed at RM 3.7. Average length for larvae and macrophothalmia was $162 \mathrm{~mm}$ and $155 \mathrm{~mm}$, respectively (Figure 20).

A summary of mark - recapture data and corresponding abundance estimates of macrophothalmia and larvae are provided in Table 12. Total sample numbers are presented in Appendix Table 2. Results suggest an increase in the population of macrophothalmia over the last two years. 


\section{Abundance and Survival}

\section{Migrant Abundance and Survival}

Production Fish: Significantly improved survival was observed for Umatilla Hatchery spring chinook salmon (mean 130.7\%) over fish from the Little White Salmon (7.8\%) and Carson National (9\%) fish hatcheries (Table 13). Mean survival of fish from super-oxygenated Michigan ponds (M1A-M1C; 139.1\%) was slightly higher than that of standard-reared fish (O5A and $\mathrm{O} 5 \mathrm{~B} ; 134.5 \%)$. In addition, fish acclimated over winter at RM 80 (4 months; O5A and O5B;114.3\%) displayed reduced survival over standard-acclimated fish (1 month;O4A and O4B; $134.5 \%$ ). Due to high variability from annual trap efficiencies, confidence intervals were relatively wide and survival estimates high.

Spring chinook reared at Little White Salmon Hatchery and released in March, exhibited fewer detections and poorer survival than fish released in April. However, regardless of the hatchery, rearing or acclimation strategy applied, the overall survival of March (early) released fish was significantly greater than April (late) release groups. The overall migrant survival of tagged spring chinook was $94.3 \%( \pm 18.6 \%)$.

Detection and survival of yearling fall chinook salmon was lower for March-released fish than April-released fish (Table 13). Overall, 53.5\% of the tagged yearling fall chinook from these two release groups survived to the lower Umatilla River $( \pm 14.6 \%)$.

Survival estimates for tagged subyearling fall chinook salmon reared at the Umatilla Hatchery, ranged between $97.7 \%-126.4 \%$ (Table 13). Fish acclimated and released at RM 73.5 exhibited slightly higher survival rates $(120.8 \% \pm 17.2 \%)$ than fish direct released at RM 48.5 $(103.2 \% \pm 15.8 \%)$. The overall migrant survival of tagged subyearling fall chinook, regardless of acclimation or release strategy applied, was $112 \%( \pm 11.7 \%)$.

Survival estimates for hatchery summer steelhead indicated that large-grade steelhead tended to survive better than small-grade steelhead (mean 57.8\% vs.38.3\%). In addition, fish acclimated and released at Minthorn (RM 64.5) generally displayed improved survival over those released upstream, at Bonifer Springs (RM 79 ${ }^{\mathrm{e}}$ ). Regardless of size or release location, however, Marchreleased steelhead (early) did not survive as well (45.6\%) as April-released fish (47.8\%). The overall survival of tagged summer steelhead reared at the Umatilla Fish Hatchery was $43.2 \%$ $( \pm 7.8 \%)$.

Cascade Hatchery coho displayed significantly improved survival (mean 37.7\%) over fish reared at the Herman Creek Hatchery (7.4\%). Furthermore, March-released fish survived better, than those released in April. The overall survival of tagged coho salmon was $30.1 \%( \pm 10.2)$.

Natural Fish: Detection, abundance and survival estimates for tagged natural spring chinook salmon varied widely due to variable sample sizes (Table 14). Survival rates ranged from $73.6 \%$ for fish tagged and released in the Umatilla River (RM 80) to $12.8 \%$ for fish released in Meacham Creek (RM 2; Umatilla River RM 79). Migrant survival was unable to be estimated for Squaw Creek releases due to the small sample size. 
Only three (3) natural coho salmon were detected in the lower river from the upper-river tag site at RM 80. Migrant survival was estimated at $4 \%( \pm 3.8 \%)$.

Percent detection and survival of natural summer steelhead was highest and most similar for steelhead tagged and released in the upper Umatilla mainstem (RM 80) and Birch Creek tributaries (RM16; Table 14). The least detections obtained were from fish tagged and released in Squaw Creek (RM 77). Overall percent detection of tagged natural steelhead was $6.3 \%$ and estimated migrant survival was $26.4 \%( \pm 5.7 \%)$.

Migrant abundance of natural salmonids sampled at the trap sites between January and December, is presented in Table 15. Abundance of natural chinook salmon includes both races (spring and fall chinook) and age classes $(0+$ and $1+)$ of fish. Migrant abundance of chinook salmon peaked in June, and was comprised of primarily subyearling fish (99\%). Total chinook salmon abundance was 37,697 fish, of which 7,406 (20\%) were estimated to be primarily spring yearlings and 30,291 (80\%) were estimated to be subyearling spring and fall chinook.

Abundance of natural coho salmon peaked in May (63\%). Total abundance was estimated at 9,444 fish, and comprised of both yearling and subyearling age classes (ascertained in the field as natural, apart from an unmarked designation). Natural summer steelhead were most abundant in May as well, with $73 \%$ of the fish being sampled during the month. All age classes of steelhead were represented, with an estimated total abundance of 33,844 fish.

\section{Reach-Specific Survival}

ANOVA testing with transformed data indicated significant differences in survival among sites for both large and small-grade summer steelhead $(P=0.036$; Table 16). Large and smallgrade fish released at RM 9 exhibited significantly improved survival over upriver releases; survival decreased incrementally with increased river mile of release. Survival was 9-18\% higher for small-grade fish released at RM 27 and RM 48, than it was for large-grade fish from the same sites.

As with in-river survival, ANOVA testing with transformed data indicated a significant difference in percent detection among sites $(P<0.001$; Table 16). Fish released at lower river sites were detected significantly more than fish released at upper river sites.

\section{Transport Evaluation}

Transport evaluation tests revealed an overall increased detection of transported fish versus non-transported fish (Table 17). Percent detection of non-transported subyearling fall chinook direct released at Westland Canal during peak in-stream temperatures $\left(17-23{ }^{\circ} \mathrm{C}\right)$ and low flow conditions (191-217 $\mathrm{f}^{3} / \mathrm{s}$ ) was $1.1 \%$. Transported fish (treatment groups) on the other hand, displayed detection rates ranging from $5.1 \%$ to $11.4 \%$. Binomial testing indicated a significant difference in percent detection between groups; non-transported fish were detected significantly less than transported fish. 


\section{Environmental Conditions and Bypass Operations}

River flows were generally lower in 2001 compared with previous years (Figure 21). Flows never exceeded $2,000 \mathrm{ft}^{3} / \mathrm{s}$ in 2001 compared to 6 days in 2000 and 14 days in 1999 . Mean monthly flow ranged from 42 to $1,062 \mathrm{ft}^{3} / \mathrm{s}$ with the peak occurring on 26 March 2001 . This was 10 days later and $64.9 \%$ less than the peak in 2000 . Flows were below $50 \mathrm{ft}^{3} / \mathrm{s}$ for 41 days in 2001 compared to 21 and 32 days in 2000 and 1999, respectively. The lowest mean daily flow $\left(1.5 \mathrm{ft}^{3} / \mathrm{s}\right)$ occurred on 17 July in 2001 compared to $39.8 \mathrm{ft}^{3} / \mathrm{s}$ on 13 July in 2000 .

Secchi depth was inversely related to river flow $(r=-0.665, P=0.000$, and $N=186$; Figure 23). Secchi readings reached a minimum depth of $\leq 0.5 \mathrm{~m}$ on five separate occasions in January and February, and a maximum depth of $2.43 \mathrm{~m}$ was observed on 19 September 2001. In general, turbidity was high from February until April when flows ranged between 365 and 1,062 $\mathrm{ft}^{3} / \mathrm{s}$. Turbidity was low during the summer and fall months when river flows were minimal.

Daily mean water temperature at RM 3.7 ranged from a low of $1.7^{\circ} \mathrm{C}$ (26 January 2001) to a high of $24.4{ }^{\circ} \mathrm{C}$ (10 July 2001) (Figure 24). The average water temperature during the 2001 monitoring period was $11.9^{\circ} \mathrm{C}$.

McKay Reservoir releases were similar in the fall, later in the spring, and earlier in the summer in 2001 compared to 2000 and 1999 (Figure 22). Late summer releases were the lowest observed in the last three years. Reservoir releases appeared to have no direct effect on the migration of most species/rear type of juvenile salmonids. However, releases did help maintain lower-river flows at or above $50 \mathrm{ft}^{3} / \mathrm{s}$ until early July.

Correlation analysis indicated a, significant, weak negative relationship between mean daily river flow and daily detection of PIT tagged natural summer steelhead (Table 18; Figure 25). Mean water temperature was positively correlated with daily detections of natural summer steelhead. The majority of the daily detections were observed at flows $\geq 1,000 \mathrm{ft}^{3} / \mathrm{s}$ and water temperatures less than $10.0{ }^{\circ} \mathrm{C}$ (Table 18). However, the highest detection rate was observed when river flows were less than $250 \mathrm{ft}^{3} / \mathrm{s}$. Approximately $1 / 3$ of the natural summer steelhead detections were observed at water temperatures greater than $17.2^{\circ} \mathrm{C}$. However, temperatures were greater than $17.2^{\circ} \mathrm{C}$ for only $15.9 \%$ of the detection period. In addition, PIT tagged natural summer steelhead appeared to migrate in three distinct temporal groups, with increasing magnitude as the migration season progressed. An early group peaked in mid-March, a second group in late April, and the third group in late May.

No relationship existed between the daily detection of PIT tagged natural chinook salmon and mean daily river flow (Table 18; Figure 26). A weak, significant, positive relationship was observed between daily detections and water temperature. The majority of the daily detections were observed at flows $\geq 1,000 \mathrm{ft}^{3} / \mathrm{s}$, which was present for the bulk of the detection period (Table 19). Natural chinook salmon tended to be detected on a falling or rising limb with only $4 \%$ being detected at a constant flow level. Nearly all daily detections were observed at water temperatures $<15.0{ }^{\circ} \mathrm{C}$. No detections were observed at temperatures above $20.0{ }^{\circ} \mathrm{C}$.

No relationship existed between daily PIT tag detections of hatchery spring chinook salmon and river flows or water temperature (Table 18; Figure 27). Fish moved out in two groups. 
Early releases quickly moved out of the system prior to peak spring flows and later releases migrated over a broader temporal distribution which was more closely synchronized with river flow $(r=0.478, P=0.010, N=23)$.

No correlation was present between daily PIT tag detections of hatchery yearling fall chinook salmon and river flow. However, a positive, significant, relationship existed with water temperature (Table 18; Figure 27).

No correlation was evident between daily detections of PIT tagged hatchery coho and river flow or water temperature (Table 18; Figure 27). The majority of the detections were observed on a falling limb well after the peak in spring river flow.

The daily detection of PIT tagged large-grade hatchery summer steelhead had a weak, significant, positive relationship with water temperature, but no relationship with river flow (Table 18; Figure 28). No relationship existed between the daily detection of PIT tagged smallgrade hatchery summer steelhead and river flow or water temperature (Table 18; Figure 28).

Correlation analysis indicated a significant negative relationship between mean daily river flow and daily detection of PIT tagged hatchery subyearling fall chinook salmon (Table 18; Figure 28). Mean water temperature was not correlated with daily detections of subyearling fall chinook salmon. Nearly $99 \%$ of the total detections for hatchery subyearling fall chinook salmon were observed within 12 days after being released.

Travel speed was positively, significantly, related to river flow within all river corridors for both large and small-grade hatchery steelhead (Table 20).

Correlation analysis indicated no relationship between daily canal diversion rate and daily trap efficiency estimates for hatchery spring, yearling fall, subyearling fall, and natural chinook salmon (Table 21). Hatchery steelhead also exhibited no relationship, however, the daily trap efficiency estimates for natural steelhead had a positive, significant, relationship with daily canal diversion rate. Daily trap efficiency for coho of unknown origin also had a positive, significant, relationship with daily diversion rate. Correlation analysis also indicated that the daily percent detection of all PIT tagged fish increases with daily diversion rate $(r=0.244, P=0.016$, and $N$ $=97$ ).

Correlation analysis indicated no relationship between daily water discharge from McKay Reservoir and daily PIT tag detections for all specie/rear type except hatchery yearling fall chinook, natural spring chinook salmon, and natural summer steelhead. The daily sample number of natural subyearling chinook salmon was correlated with daily water discharge from McKay Reservoir (Table 22). 


\section{DISCUSSION}

\section{Outmigration Monitoring}

Few changes were seen in migration parameters of hatchery or natural juvenile salmonids compared with previous years (Knapp et al, 2000 and 2002 and Ehlers et al, 2001). One distinction noted however, was in spring chinook salmon travel speeds for fish reared at Umatilla Hatchery. Travel speeds for spring chinook released in March were substantially higher than those of fish from all other rearing and release strategies. This was consistent with the last four years of data (1998-2001). Differing travel speeds may have been a result of the larger size of Umatilla Hatchery reared fish in 2001 (10.3-10.5 fish/lb). Beckman et al (1998) found that smolt size and migration were related, with larger fish moving downstream sooner than smaller fish. An even stronger relationship was noted between growth rate and migration parameters. Migration parameters for spring chinook salmon reared at Little White Salmon Hatchery and released in March of 2001 were not discernible due to low detection rates. This group of fish was diagnosed with high grade BKD and therefore may not have survived to the lower river (Onjukka, personal communication 2001).

March-released hatchery yearling fall chinook salmon traveled slower than April-released fish. This was consistent with previous years. Guillermo et al (1997) found that fish emigration rate decreased with temperatures. Temperature in the Umatilla River is typically $3-5^{\circ} \mathrm{C}$ cooler in March than April, which may have resulted in slower emigration to the lower river.

Hatchery subyearling fall chinook travel speeds have varied from year to year. Mean travel speed increased with size at release in 2000 and 2001 (28.2 and $20.9 \mathrm{mi} / \mathrm{d})$ compared with decreasing trends in 1998 and 1999 (12.5 and $4.9 \mathrm{mi} / \mathrm{d})$. Subyearlings are typically released in late May and early June when water quality is poor due to high stream temperatures and low flows (CTUIR and USBR personal communication, 2001). It therefore, may be beneficial for fish to leave the Umatilla quickly and enter the Columbia River mainstem where temperatures are cooler and flows are more constant. Reach survival tests in 2000 for subyearling fall chinook salmon indicated that fish released at the mouth of the Umatilla River had significantly higher detections than all other release sites (Knapp et al 2002). We should consider releasing subyearling chinook salmon at a larger size in order to increase travel speeds and decrease residency time in the Umatilla River.

Hatchery coho salmon migration parameters have not changed a great deal over the past four years. Fish released in March and April typically have not peaked in the lower river until early to mid-May. With the use of PIT tags in 2001, differences in migration patterns among various rearing and release groups could be discerned. Migration patterns appeared to be similar for all groups, but detections from March released fish were low, especially for fish from the Herman Creek Hatchery ( $\mathrm{N}=7$ versus $\mathrm{N}=80$ for April released fish). It is therefore, uncertain if the migration pattern of March released fish in 2001 depicts typical behavior. Coho salmon reared at Herman Creek Hatchery were diagnosed with EIBS, which may have affected their detection rate and survival to the lower river (Onjukka, personal communication 2001). Fish reared at Cascade Hatchery and released in March also had low detections $(\mathrm{N}=17$ versus $\mathrm{N}=$ 80) but did not test positive for EIBS. However, March-released coho were smaller than April releases which also could have delayed migration and inhibited survival (Beckman et al. 1998). 
In addition, preliminary analysis of 2002 data indicates that percent detection of March released fish is half of that of the April releases. This suggests that fish released in March perform poorly compared to April released fish, which may be a result of size at release or differences in water temperature.

Hatchery summer steelhead migration continued to be predictable, with fish exhibiting slow travel speeds $(1.7-3.6 \mathrm{mi} / \mathrm{d})$ and detection peaking in late May to early June. Small-grade fish released three weeks later than all other groups traveled the fastest. This was similar to findings from previous years (Knapp et al, 2000 and 2002 and Ehlers et al, 2001). Similarly, hatchery fish migration parameters mimicked those of natural fish, even though hatchery salmonids were $45-55 \mathrm{~mm}$ larger in size. Travel speed of hatchery steelhead was similar to natural fish released in the mainstem Umatilla and Meacham Creek. However, natural fish released in all other tributaries traveled 2 to 8 times slower than hatchery salmonids. This was also similar to previous years and may be a result of the time of tagging and the smoltification status of the natural fish at the time.

Natural subyearling chinook salmon continued to peak in June and move throughout the summer when flow was available. 2001 was the second year flow has been available during the summer to trap in the lower river. In July, 65 fish were sampled within a 3 day period then the trap was shut down due to low flow conditions. Cooperating management entities should work together to ensure constant flows in the lower Umatilla River throughout the summer, which would allow for the life histories of all salmonids to be expressed (Knapp et al 2002).

Correlation analysis indicated no relationship between descaling rate and various environmental factors. Hatchery fish were descaled at more than twice the rate of natural fish. In addition, the descaling rate for hatchery summer steelhead (largest outmigrant) was $40 \%$ greater than any other species/rear type. This suggests that multiple factors contribute to descaling rate, including species type, origin, and size.

Body injuries attributed to avian predators continues to increase, with hatchery fish being more susceptible to bird injuries than natural fish. Decreasing flows and minimal turbidity during the last three spring outmigration periods has likely increased avian predation by making both hatchery and natural fish more conspicuous and easier to capture. The noticeably higher percentage of hatchery fish with bird marks is possibly due to a prolonged residency in the river, bird predation at acclimation ponds, and unnatural rearing environments (Knapp et al. 2000). In addition, the higher susceptibility of hatchery summer steelhead in 2001 suggests a sizedependent selection by avian predators. Collis et al. (2001) found that steelhead smolts were more vulnerable to avian predation than yearling chinook salmon and attributed this to a sizedependent selection by avian predators. They also concluded that hatchery-reared juvenile salmonids were more susceptible to avian predation due to a suite of factors including behavioral and physical traits, elevated stress levels associated with handling, lack of both innate and learned predator avoidance, and a tendency to be more surface-oriented. As reported and recommended in previous reports, avian predation is a serious risk to the survival of natural and hatchery juvenile salmonids in the Umatilla River, and progressive measures to deter losses due to avian predation need to be addressed (Ehlers et al. 2001; Knapp et al. 2000, 2002). 
Parasites, predominately black spot, continue to be more prevalent among natural chinook salmon and summer steelhead compared to their hatchery counterparts. The rate of body injuries, including torn or split caudal fins, eye and operculum damage, and fungus, was the highest observed in the last three years (Ehlers et al. 2001; Knapp et al. 2000, 2002). This is possibly linked to the increase in the rate of bird marks observed over the same time period.

The total number of juvenile lamprey migrating out of the Umatilla River continues to be low, however, trapping numbers over the past four years have increased. In addition, abundance estimates for 2001 were greater than those for 2000 . These results indicate that natural production is at very low levels; however, it is increasing and may continue to increase if supplementation through adult outplanting is successful. Juveniles from the initial outplanting of 600 adults in 2000 are expected to contribute to the total number of outmigrants starting in 2004 (Close, 2002; Close et al 2002).

\section{Abundance and Survival}

Production Fish: Migrant survival of tagged hatchery fish groups in 2001 varied considerably over past years. Survival of hatchery spring chinook salmon reached an overall high of 94.3\%, in comparison to 1999 (47.9\%) and 2000 estimates (34.7\%). Subyearling fall chinook survival was also substantially higher in $2001(112 \%)$ in comparison with previous years $(2000-64.6 \% ; 1999-53.4 \%)$. This increase in survival may be due to improved hatchery rearing and release strategies or environmental conditions, but is more likely a result of low and variable trap efficiencies, which hindered estimate accuracy.

Umatilla Hatchery spring chinook survived significantly better in 2001 over fish from the Little White Salmon and Carson National fish hatcheries. This was contrary to previous findings and may be a result of disease prevalence apparent in Little White and Carson hatchery fish. An increased loss investigation of fish from the Little White Salmon hatchery subsequent to transport to the acclimation facility, revealed bacterial kidney disease (BKD) to be the cause (S. Onjukka, pers. comm. 2002). Due to its chronic and persistent nature, BKD may also have adversely affected chinook health during emigration, further reducing survival (Groberg and Onjukka 1992). Additionally, Infectious hematopoietic necrosis virus (IHNV) was detected in $30-35 \%$ of Little White Hatchery grab sampled fish and $100 \%$ of moribund viral sample pools (S. Onjukka, Quarterly Report 2001). The severity of potential impact and ease of transmission of this virus both horizontally and vertically makes it logical to suspect that it may have contributed to increased losses during fish transport and migration (Anderson et al. 2000; S. Onjukka ODFW Memo 2001).

Pathogens were also evident in Herman Creek hatchery coho salmon, indicating disease may have been a factor other than release strategy affecting migrant survival (Onjukka, pers. comm. 2002). Pathology sampling revealed the presence of erythrocytic inclusion body syndrome (EIBS) and higher levels of Flavobacterium psychrophilum [the causitive agent in bacterial cold water disease (CWD)] in Herman Creek hatchery fish compared with fish from the Cascade National Fish Hatchery. 
Hatchery spring chinook outmigrants reared in super-oxygenated Michigan ponds once again displayed improved survival over standard-reared fish. Although consistent with 1999 and 2000 study results (Knapp 2000 and 2002), this was opposite to trends exhibited by smolt-toadult survival data (Chess, in progress, 2003). Mean smolt-to-adult survival of hatchery spring chinook (BY93 to BY98), was greater for Oregon-reared fish over Michigan. This suggests that super-oxygenated rearing strategies may benefit salmonid survival in the short-term (Maynard et al. 1995), however, it does not provide a long-term survival advantage over standard-reared fish. In addition, spring chinook released in April continued to display improved survival over March released fish (Knapp 2000 and 2002). Similar results were evident for yearling fall chinook, coho salmon and hatchery summer steelhead migrants, suggesting that a later release date contributes to a potential survival advantage. This was also consistent with trends exhibited by smolt-to-adult survival results (Chess, in progress, 2003).

Contrary to previous findings, over-wintering of spring chinook did not reveal improved outmigrant survival over standard-acclimated fish (Knapp 2000 and 2002). This inconsistency with previous data, may be a result of variable trap efficiencies affecting survival estimates.

Subyearling fall chinook salmon acclimated and released at RM 73.5 faired better than fish direct released at RM 48.5. Similarly, fish released at upper river sites in 2000 exhibited improved survival over lower river releases. In addition, migrant survival was roughly $50 \%$ greater in 2001 than estimated the previous year (Knapp 2000 and 2002). Although 2001 was the first year of combining acclimation strategies with release location, results suggest that the combination of the two strategies may provide a survival advantage for emigrating hatchery produced subyearling chinook. This increase in migrant survival may be due to the change in acclimation facility (from RM 56 vs. RM 73.5) or fewer mortalities from caudal-fin erosion and tail fungus outbreaks as evident in 2000. Increased survival may also be attributed to the reduction in the subyearling production program from 3 million fish to 600,000 .

Critical to shaping the production program are valid abundance and survival estimates. 2001 data revealed extremely high survival estimates for hatchery spring and subyearling fall chinook salmon. These "overestimates" are likely a result of low and variable trap efficiencies, which may be an artifact of the number of fish tagged or flow conditions affecting detection at the facility (Knapp et al. 2000 and 2002). Additional speculation is that the fish used in trap efficiency tests were collected at Three Mile Dam and thus may be exhibiting avoidance patterns, leading to low recapture rates. Production fish were also released and detections peaked for both races, 1-2 days prior to trap efficiency tests being conducted. Therefore, the peak pulse of downstream fish movement of hatchery fish may have been influenced by factors other than those of fish used in trap efficiency tests.

Large-grade steelhead migrants exhibited improved survival over small-grade steelhead migrants. This was consistent with findings from 1998 and 1999 work (Knapp 1998 and 2000), as well as smolt-to-adult survival estimates (Chess, in progress, 2003). The lower survival success of steelhead smalls may be indicative of their potential to over-winter and migrate out as two year old fish (Knapp et al. 2000). Forcing these fish into a 1-year smolt goes counter to the desired goal of mimicking natural life history patterns (Knapp et al. 2002). 
Seven years of outmigration monitoring data has indicated the Minthorn acclimation site (RM 64.5) to be a superior release location over that of Bonifer Springs (RM 79; Meacham RM 2). This was also supported by adult returns and smolt-to-adult survival trends (BY91 to BY97; Chess, in progress, 2003).

Overall survival of emigrating hatchery summer steelhead was not as good in 2001, in comparison with previous years (43\% 2001 vs. 56 and 63\% in 1999 \& 2000, respectively; Knapp 2000 and 2002). High stream temperatures $(\geq 17.8 \mathrm{C})$ coinciding with steelhead migration may have influenced emigration success (Brett 1952). Additionally, predation of hatchery summer steelhead appeared relatively high in 2001, based on the high percentage of bird marks, and may have contributed to increased mortality.

Natural Fish: Natural salmonid production dropped in 2001 compared with previous years. Production of coho salmon notably decreased in 2001 with $2 / 3$ fewer migrants $(9,444)$ than observed in $2000(30,163)$. Migrants (yearling and subyearling) were derived from adult returns in 1999 (3,702; Zimmerman et al. 2000) and 2000 (4,654; Zimmerman et al 2001). With a combined adult return of nearly 23,000 coho (natural and hatchery) in 2001 (Zimmerman 2002), smolt production is expected to rise again in the next couple of years, particularly if conditions are favorable.

Natural chinook salmon abundance also declined in 2001, compared to the previous year. A total of 46, 764 migrants were estimated in 2000, compared with 37,697 in 2001 . This $20 \%$ drop in natural production appeared to be derived from a decline in the number of emigrating yearling spring chinook. Estimates for subyearling chinook remained steady at approximately 30,000 fish, whereas yearling chinook abundance dropped by almost 50\% (7,406 migrants in 2001 vs. 15,055 in 2000). Spring chinook migrants were derived from 1998 and 1999 combined hatchery and natural adult returns. Interestingly, spring chinook available to spawn in 1998 was $1 / 5^{\text {th }}$ that estimated in 1999 (207 potential spawners vs. 1020 potential spawners; Chess, in progress 2003).

Migrant abundance of natural summer steelhead dropped by almost $60 \%$ in 2001, compared with 2000 estimates. Steelhead abundance was estimated at 33,844 migrants in 2001 and 81,759 in 2000. This decline in production may be an artifact of high water temperatures near the end of the migration period, which may have contributed to increased mortality. Over $1 / 3$ of tagged natural steelhead migrants were detected at temperatures between 18 and $22{ }^{\circ} \mathrm{C}$, which are known to be within sub-lethal limits for juvenile salmonids (Brett 1952). Additionally, adult escapement in 1998-1999 was 28\% less than it was the previous season. As the majority of migrants were age-2 smolts (Knapp 2002), this drop in escapement may also have contributed to the abundance decline.

Migrant survival of PIT-tagged natural fish groups in 2001 was estimated at $70.7 \%( \pm 36.5)$, $4.0 \%( \pm 3.8)$ and $26.4 \%( \pm 5.7)$ for spring chinook salmon, coho and summer steelhead, respectively. Confidence in survival estimates was generally much improved over previous years, and likely a result of increased numbers of fish tagged and refinement in project methodology. 
Rough calculations suggest migrant abundance of natural salmonids in 2001 to be between $1 \%$ and $52 \%$ of that of hatchery produced fish. Of the total estimated abundance of emigrating salmonids in the Umatilla River basin, approximately $1 \%$ of coho were estimated to be natural, $11 \%$ of chinook and $52 \%$ of steelhead.

Reach Specific Survival: A fourth year of reach survival tests indicated an increasing trend in survival, with decreased river mile of release. This was consistent with 1998-2000 findings. In addition, early released fish generally displayed reduced survival over later released fish. This was also consistent with previous findings and most apparent with large grade steelhead. This improved survival may be due to warmer water temperatures which may have stimulated migration. As previously noted, water temperatures are typically cooler at upriver release sites, which may slow fish migration and contribute to decreased survival (Guillermo et al, 1997). Four years of reach survival results suggest that the Bonifer Springs release site should be eliminated as a steelhead release location. Additionally, it may be beneficial to find an alternative release site to Minthorn Springs

Three small-grade summer steelhead released for reach survival tests in 2001, were detected at RM 3.7 in 2002. Similar behaviors were exhibited in fish from tagged production release groups. This suggests that an undisclosed number of small-grade summer steelhead are overwintering in the Umatilla River and migrating out as 2 year old fish. As the most common age for migration of natural steelhead is age-2, this supports the notion that forcing hatchery steelhead into a 1 year old smolt goes counter to the desired goal of mimicking natural life history pattern (Knapp et al, 2000 and 2002).

Transport Evaluation: Past transport evaluation studies conducted on the Umatilla River have provided mixed results in determining the effects of transportation on the survival of hatchery subyearling chinook salmon. Knapp et al (1998a and 1998b) reported that nontransported chinook salmon had a higher survival rate compared to transported fish. However, a study by Walters et al (1994) indicated no significant difference between the short-term mortality of non-transported and transported fish. All evaluations (Knapp et al. 1998a and 1998b; and Walters et al. 1994) identified transportation as a stressful process due to crowding and loading procedures; however, linking these procedures directly to mortality is a more challenging task.

Current transport evaluation results using PIT tagged hatchery subyearling chinook salmon have indicated that transported fish have a higher overall detection rate at mainstem Columbia River dams than non-transported fish. This suggests that survival of transported fish may be higher than that of non-transported fish. However, numerous biases were associated with the experimental design and variable environmental conditions provided additional constraints to the experiment. For example, control fish (non-transported) were transferred to and held at Westland Canal prior to being direct released. A true control fish would not be subject to any transportation or holding procedures. In addition, low flows required control fish to be released at an earlier date compared to transport of treatment fish, and control fish were exposed to an increased level of avian predation while being held at Westland Canal.

Preliminary recommendations to basin co-managers are not to rely on transportation as a long-term management strategy and to pursue additional research to clarify the benefits associated with McKay Reservoir releases in relation to salmonid production. Boyce (1986) 
indicated that trap and haul operations be used only as a temporary fix and that flow enhancement would be the only acceptable way to meet long-term fishery goals in the Umatilla River. Current management strategies (McKay Reservoir releases and water exchange agreements) appear to be assisting with the natural (unassisted) emigration of juvenile salmonids within the Umatilla River basin and as such reducing the number of fish required to be transported (ODFW and CTUIR, 2000; and Zimmerman and Duke, 2001). However, the ability to provide constant instream flows during summer months would likely eliminate the need for fish transportation, increase juvenile production, and provide passage for adult Pacific lamprey and summer steelhead.

Possible strategies to ensure adequate instream flows throughout the entire year include the operation of Phase I exchange throughout the summer, increasing the amount of stored water allocated for juvenile salmonid passage in McKay Reservoir, or a combination of the two. More monitoring should be conducted to directly address the overall benefits of current and alternative management strategies of flow enhancement projects. Specifically, transport evaluations should be conducted when in-river conditions are being enhanced by McKay Reservoir releases. This would allow for the comparison of survival between transported fish and in-river migration when conditions are being enhanced. Research should also be conducted to evaluate the effects of transportation on returns of hatchery and natural fall chinook salmon, not just the relative survival of juveniles.

\section{Environmental Conditions and Bypass Operations}

Identifying and quantifying the effects of environmental variables on the migration of juvenile salmonids in the Umatilla River has proven to be a difficult challenge over the past several years (Ehlers et al. 2001; Knapp et al. 2000, 2002). Seasonal variation in natural and augmented river flows, irrigation diversion, water temperature, hatchery fish release sites, dates, and size are among the possible factors leading to this difficulty. Another problem is the irregular and altered hydrographs of the Umatilla River due to its geology, reduced riparian vegetation, and numerous irrigation projects. Flows often change rapidly in response to rainstorms and snowmelt due to the steep-sided canyons, basalt bedrock channels, and lack of vegetation throughout the lower portions of the watershed. Flows can also be drastically changed from one river reach to the next due to the specific operations of an irrigation project (Contor, 1996; Boyce, 1986). Also, individual fish from a single release group do not migrate together but spread out over time. If conditions rapidly change, as they often due in the Umatilla River, in relation to the amount of time it takes the majority of the group to migrate through a particular river section, then different fish from the group will encounter varying environmental conditions. Additionally, environmental variables can act as proximal or ultimate factors in directing fish behavior and the physiological or ecological well-being of a fish (Reynolds, 1977). This makes it difficult to determine the actual effect an ecological variable has on a fish or a group of fish.

In accord with the aforementioned difficulties, hatchery fish exhibited inconsistent, and mostly non-significant relationships between percent PIT tag detections and various environmental factors. Similar results by Gallinat et al. (2001) indicated that no significant relationships existed between the number of hatchery spring chinook salmon smolts captured at a 
rotary-screw trap and river flow, staff gauge level, time of year, water temperature, air temperature, or turbidity. In the Umatilla River, subyearling fall chinook salmon were the only production group with a significant relationship between migration timing and river flow. As in past years, a negative association was observed which is likely due to the tendency of these fish to migrate quickly after release, as well as their releases occurring at summer low flow conditions (Ehlers et al. 2001; Knapp et al. 2000, 2002). In addition, nearly all the 2001 hatchery fish releases occurred after the spring peak in river flows, which likely reduced the significance that river flows may provide in stimulating migration and the influence river flow has on the travel speed of juvenile salmonids (Berggren and Filardo, 1993; McCormick et al. 1998; Smith et al. 2002; Whalen et al. 1999). However, correlation analysis indicated a positive relationship between travel speed of PIT tagged hatchery summer steelhead and river flow. This is consistent with Berggren and Filardo (1993), and Smith et al. (2002) in that smolt migration rates increase as river flow increases.

The migration timing of hatchery yearling fall chinook salmon and large-grade hatchery summer steelhead was positively related to water temperature. This is likely due to the majority of these fish being intermediately smolted upon release. This possibly caused the fish to remain near their release site until water temperatures increased causing their level of smoltification to rise and initiate downstream movement (Ewing et al. 1980, 1984; Hoar 1976, 1988; Stonecypher et al. 2001; Wedemeyer et al. 1980). The size and developmental classification of small-grade and large-grade hatchery summer were similar at their time of release and the migration timing of small-grade hatchery summer steelhead was positively correlated with water temperature; however, the relationship was not significant. Possible reasons for these groups of fish not being smolted upon release include culture conditions such as constant water temperature and nutrition, as well as increased social interactions. Past studies have linked the smoltification process to an increase in spring growth rate, which likely does not occur in a controlled hatchery environment (Beckman et al. 1999, 2000; Ewing et al. 1980). It is possible that the spring growth of summer steelhead reared at Umatilla Fish Hatchery is affected when they are transferred from constant and generally warmer temperature hatchery ponds $\left(13.3{ }^{\circ} \mathrm{C}\right)$, into ambient river fed acclimation ponds that generally range in temperature from 6.0 to $14.0{ }^{\circ} \mathrm{C}$. A reduction in growth rate may occur during the liberation and acclimation of these fish and could possibly alter their smolting. However, this is not likely the case for yearling fall chinook salmon because they are reared at Bonneville Fish Hatchery, which is supplied by ambient Columbia River water thus having a similar water temperature range as the acclimation ponds (Stonecypher, pers. comm, ODFW, 2002). Therefore, the reduced smoltification level upon release of hatchery yearling fall chinook salmon could be due to their lengthened rearing time. Natural fall chinook salmon in the Columbia River and its tributaries have an ocean-type life history, in which fry emerge from the gravel in the spring, rear for a couple months in freshwater, and then migrate to the ocean as subyearlings (Healey, 1991). Altered rearing time due to hatchery practices is also likely to influence the smolting of hatchery summer steelhead. Hatchery broodstock is taken from the natural summer steelhead population in the Umatilla River, which predominately migrate as 2year old smolts. The current hatchery strategy is to release 1-year old smolts. This likely affects the smoltification process and migration timing of these fish (Knapp et al. 2000 and 2002).

Additional factors that may be responsible for the inconsistent migration patterns of hatchery fishes in 2001 are the fishes physical condition upon release (scale loss, fish size, and disease presence/absence), poor overall water conditions, release strategy, release timing, and 
release location. Schuck et al. $(1995,1997)$ found that fish size, condition factor, and degree of smoltification are strongly related to the emigration performance of hatchery summer steelhead volitionally released from an acclimation pond into the Tucannon River. Their study also found that direct-stream released fish, with PIT tags, had higher detection rates at mainstem dams than those volitionally released from an acclimation pond. Additional work in the areas of growth rate and the smolting process of Umatilla River production fish is needed if a better understand of smolt emigration is desirable.

Natural smolts also exhibited mixed results between river flow and percent PIT tag detections, as well as water temperature and percent PIT tag detections. Detection of PIT tagged natural summer steelhead was negatively associated with river flow. This is possibly due to the low river flows being unable to function as a proximal stimulus to cue downstream movement. Several studies have linked the downstream movement of smolts with increased river flow and peak discharge events, however no such relationship was obvious in the Umatilla River (McCormick et al. 1998; Whalen et al. 1999).

Water temperature was positively correlated with the migration of natural summer steelhead. This is likely due to the direct role water temperature plays in the physiological process of smoltification (Ewing et al. 1980, 1984; Hoar 1976, 1988; Wedemeyer et al. 1980). It appears that natural summer steelhead did not migrate until water temperatures began to rise and the level of smoltification increased to a point at which fish began to move downstream. Numerous studies have also linked the emigration timing of smolts with water temperature (McCormick et al. 1998; Roper and Scarnecchia, 1999; Whalen et al. 1999). No relationships existed between environmental variables and the outmigration of natural chinook salmon.

Similar relationships between natural fish movement and environmental factors were evident in 1999 and 2000 compared to 2001. Similar water conditions existed in 2000 compared to 2001, however, 1999 flow conditions were much more episodic. This indicates that river flow only provides a stimulus for migration and that factors such as photoperiod, growth rate, temperature, and fish size are more determinate triggers for smoltification and the outmigration of juvenile salmonids (Beckman et al. 1999, 2000, Berggren and Filardo, 1993; Ewing et al. 1980, 1984; Gallinat, 2001). In addition, genetic analysis of natural summer steelhead migrants from the Umatilla River indicated variable migration timing among tributary and mainstem populations, which suggest that a genetic variable is also influencing the migration of natural summer steelhead smolts in the Umatilla River (Knapp et al. 2002).

Elevated stream temperature continues to be a concern during the outmigration of juvenile salmonids from the Umatilla River. In 2001, water temperature was within sub-lethal limits $\left(17.8^{\circ} \mathrm{C}-23{ }^{\circ} \mathrm{C}\right)$ for 92 days of the monitoring period (Brett, 1952). Only a few detections of PIT tagged natural chinook salmon were observed at water temperatures above $17.8^{\circ} \mathrm{C}$, however, nearly $1 / 3$ of the natural summer steelhead detections were observed with water temperature at or above $17.8{ }^{\circ} \mathrm{C}$. These high water temperatures, especially those observed in late May of 2001, likely reduced the emigration success of hatchery and natural subyearling chinook salmon, as well as natural summer steelhead. Hatchery subyearling chinook salmon had to be released early from the Thornhollow acclimation pond due to high water temperatures and direct-stream releases were delayed by two days for the same reason. Reports from anglers seeing dead juvenile salmonids along the riverbanks below the release sites indicated that fish 
from these release groups did not fair well. In addition, our data supports the idea that the timing of smolt migration is dependent upon water temperature (McCormick et al. 1998; Roper and Scarnecchia, 1999; Whalen et al. 1999), and continued human-caused increases in stream temperature through current land use activities will probably affect migration timing, life history characteristics, and smolt to adult survival of hatchery and natural salmonids (Quinn and Adams, 1996; Robards and Quinn, 2002).

Correlation analysis did not indicate a relationship between canal diversion rate and trapping efficiency for most species in 2001. Only natural summer steelhead and unknown coho were significantly influenced by the amount of water being diverted into the West Extension canal. However, the number of PIT tag detections tended to increase with canal diversion rate. This is likely due to the inverse relationship between canal diversion rate and river flow. As river flow increases, diversion rate decreases. This reduces the amount of attraction water entering the trap in relation to the amount of water in the river. With less attraction flow to the trapping facility, and more water in the river, more fish pass over the top of Three Mile Falls Dam. However, as river flows begin to drop in the summer, diversion rate increases and the ability to trap migrants also increases. This helps minimize facility-related delays, however, fish are typically being bypassed into an extremely poor environment below the trapping facility. River flows and water temperatures are less than optimal for these summer migrants and bird predation is likely high (Ehlers et al. 2001; Knapp et al. 2000, 2002).

Prioritized time periods and release amounts for stored water in McKay Reservoir released for fish flow augmentation were generally met in 2001, however, water was not available for release during the months of July and August (Torretta, 2000; ODFW, 2001; Zimmerman, personal communication, CTUIR, 2003). This caused the river below Three Mile Falls Dam to essential dry up from 10 July until 16 August 2001. Correlation analysis indicated that nonregulated releases in the early spring appeared to benefit the outmigration of hatchery yearling fall chinook salmon, natural summer steelhead, and natural chinook salmon. In addition, regulated releases, beginning in late May, continued to aide in the migration of natural subyearling chinook salmon during the month of June. Results from this year and previous years data suggest that current prioritized release strategies for stored water in McKay Reservoir during the month of June benefit hatchery and natural subyearling fall chinook salmon, however, more stored water needs to be allocated for fish to ensure there is water available for release during summer low flow conditions (Ehlers et al. 2001; Knapp et al. 2000, 2002). Increasing flows during July and August would likely benefit outmigrating subyearling chinook salmon and returning lamprey adults (Berggren and Filardo, 1993; Close, 2002; Tiffan et al. 2000). Additional monitoring of McKay releases would help to insure that protected blocks of water reach the mouth of the Umatilla River as intended (Torretta, 2000). 


\section{CONCLUSIONS}

\section{Abundance and Survival:}

$>$ Natural abundance of juvenile salmonids exhibited a significant decline in 2001, compared with the upward trend of previous years.

$>$ An undetermined number of hatchery summer steelhead are overwintering in the Umatilla River and migrating out as 2-year old smolts.

$>$ Transport evaluation results indicated transported fish may have a survival advantage over non-transported fish.

$>$ Four years of reach-specific survival tests have concluded survival of juvenile salmonids increases with decreased river mile of release.

$>$ Migrant survival of fish from the Little White, Carson and Herman Creek fish hatcheries were likely influenced by disease in 2001 .

$>$ Fish reared in super-oxygenated raceways have consistently displayed improved migrant survival over standard reared fish. This is opposite to smolt-to-adult survival trends.

$>$ Subyearling fall chinook acclimated prior to release displayed improved migrant survival over direct released fish in 2001.

$>$ Fish released at Bonifer Springs (RM 79) once again displayed reduced migrant survival over lower released fish.

$>$ Contrary to 2000, overwintered spring chinook did not indicate a survival advantage over standard acclimated fish.

$>$ Early released fish have consistently displayed reduced migrant survival over later released fish (ie. 1999-2001 yearling fall chinook, 2001-2002 coho; 2001 steelhead and 1999-2000 spring chinook salmon).

$>$ Large-grade summer steelhead exhibited improved migrant survival over small-grade summer steelhead. This is consistent with smolt-to-adult survival trends.

$>$ The total number of juvenile lamprey emigrating from the Umatilla River continues to be low, however, trapping numbers over the past four years have increased.

\section{Migration Trends:}

$>$ Diel patterns of hatchery and natural salmonids were similar in 2001. Most species tended to emigrate between sunrise and sunset at RM 3.7.

$>$ Migration patterns of hatchery summer steelhead appear to be mimicking those of natural summer steelhead.

$>$ Release strategies of hatchery subyearling fall chinook appear to correspond well with the downstream movement of natural subyearling fall chinook. Both groups tend to migrate between May and July.

$>$ Migration timing of natural spring chinook varies annually, however it generally occurs between March and April and appears to be consistent with hatchery releases.

\section{Environmental Conditions:}

$>$ Travel speed of hatchery summer steelhead was positively related to river flows.

$>$ Hatchery and natural smolts exhibited inconsistent, and mostly nonsignificant relationships between migration timing and environmental factors. Our results suggest however, that stream temperature is affecting the migration of juvenile salmonids in the Umatilla River by regulating the smoltification process or by acting as a stimulus to initiate downstream movement. 
$>$ High stream temperatures continue to be a concern during the outmigration period and are likely reducing the emigration success of natural and hatchery fish.

$>$ McKay Reservoir water releases appear to be aiding in the migration of natural and hatchery subyearling chinook during the month of June, however, more stored water needs to be allocated for fish to ensure water is available for late summer migrants.

$>$ In general, fish tended to be descaled and injured at a higher rate in 2001 compared with previous years; hatchery fish were more susceptible than natural.

\section{RECOMMENDATIONS}

1. PIT tagging of natural salmonids in the upper Umatilla basin should be continued in order to ascertain origin of migrating smolts, estimate outmigant survival, and monitor natural production. PIT tagging will aid in defining general trends and determining the effect of hatchery releases on natural species.

2. Coho salmon released into the Umatilla River should be clearly marked (fin clip) to differentiate between hatchery and natural fish leaving the system. If hatchery fish are clipped, then migration parameters of natural fish could be verified which would help in coho management. Clipping would also help determine the effects of hatchery production releases on natural production.

3. Discontinue use of the Bonifer acclimation site for hatchery summer steelhead. Four years of data from reach specific survival tests has shown this site to be less than optimal for producing successful migrants. The Minthorn acclimation site appears to be a better location.

4. Hatchery salmonids should be released as low in the basin as practical and managers should move towards the latest possible release date. Trends exhibited over the past three years have indicated early released fish have exhibited reduced migrant survival over later released fish. A later release would assure more fish are smolted, reduce their residency time in the river, and possibly boost migrant survival.

5. Hatchery summer steelhead overwintering trends should be closely monitored in the Umatilla River and hatchery rearing and release strategies adjusted if required.

6. Constant instream flows within the Umatilla River are vital to eliminating fish transportation, increasing juvenile production and ensuring successful passage for mid-summer migrants. Phase I exchange should therefore be encouraged and water allocations from the McKay Reservoir continued to maintain minimum flow requirements and suitable water temperatures for mid-summer migrants. Successful natural production requires a diversity of life stages and strategies which are dependent on appropriate flow conditions year round.

7. The installation of a permanent remote interrogation system at the east-bank fish ladder of Three Mile Falls Dam should be pursued and supported for detection of returning adult salmonids and juvenile migrants. This system would provide estimates on smolt-to-adult survival and elucidate passage behavior of juveniles around the dam. 


\section{ACKNOWLEDGEMENTS}

Special recognition goes to Mr. Jason Story and Ms. Danette Ehlers for many hours of trap operation and data collection. Ms. Danette Ehlers also contributed to data analysis and compilation. Ms. Suzanne Knapp oversaw project planning and field operations. She also provided much appreciated project direction and support during report compilation. The assistance of field personnel and administrators of the Bureau of Reclamation and West Extension Irrigation District was also greatly appreciated. Recognition should also be given to the fish passage facility's O\&M staff for their assistance with facility operation, repair, and modifications. In addition, recognition goes to the ODFW Pathology staff in La Grande for their analysis of fish samples and assistance in interpreting fish health results. The assistance of Irrigon and Umatilla Hatchery personnel and the staff of the Umatilla Hatchery Monitoring and Evaluation project to accommodate fish tagging and holding needs was invaluable. Additionally, the staff of the Umatilla Hatchery Satellite Facilities Operation and maintenance are thanked for their help during coho salmon tagging. Final appreciation goes to the contract monitors, Mr. Jay Marcotte and Mr. Jonathan McCloud of the Bonneville Power Administration for their ongoing support.

\section{LITERATURE CITED}

Anderson, E.D., H.M. Engelking, E.J. Emmenegger, and G. Kurath. 2000. Molecular epidemiology reveals emergence of a virlent infectious hematopoietic necrosis (IHN) virus strain in wild salmon and its transmission to hatchery fish. Journal of Aquatic Animal Health 12:85-99.

Beckman B.R., D.A. Larson, B. Lee-Pawlak, W.W. Dickhoff. 1998. Relation of Fish Size and Growth Rate to Migration of Spring Chinook Salmon Smolts. North American Journal of Fisheries Management 18:537-546.

Beckman, B.R., W.W. Dickhoff, W.S. Zaugg, C. Sharpe, S. Hirtzel, R. Schrock, D. Larsen, R.D. Ewing, A. Palmisano, C.B. Schreck, and C.V.W. Mahnken. 1999. Growth, smoltification, and smolt-to-adult return of spring chinook salmon from hatcheries on the Deschutes River, Oregon. Transactions of the American Fisheries Society 128:11251150 .

Beckman, B.R., D.A. Larsen, C. Sharpe, B. Lee-Pawlak, C.B. Schreck, and W.W. Dickoff. 2000. Physiological status of naturally reared juvenile spring chinook salmon in the Yakima River: seasonal dynamics and changes associated with smolting. Transactions of the American Fisheries Society 129:727-753.

Berggren, T.J., and M.J. Filardo. 1993. An analysis of variables influencing the migration of juvenile salmonids in the Columbia River Basin. North American Journal of Fisheries Management 13:48-63. 
Boyce, R.R. 1986. A comprehensive plan for rehabilitation of anadromous fish stocks in the Umatilla river basin. Final report of Oregon Department of Fish and Wildlife to Bonneville Power Administration, Portland, Oregon.

Brett, J.R. 1952. Temperature tolerance in young Pacific salmon, genus Onchorhynchus. Journal of the Fisheries Research Board of Canada 9:265-323.

Bronson, P. and B. Duke. 2002. Umatilla River Fish Passage Operations Project, October Monthly Report. Prepared by the Confederated Tribes of the Umatilla Indian Reservation and the Oregon Department of Fish and Wildlife.

Burnham, K.P., D.R. Anderson, G.C. White, C. Brownie, and K.H. Pollock. 1987. Design and analysis methods for fish survival experiments based on release-recapture. American Fisheries Society Monograph 5:1-437.

Chess, D.W., W.A. Cameron, R.W. Stonecypher, Jr., and R.W. Carmichael. 2003. In preparation. Umatilla Program Assessment. Prepared for the Bonneville Power Administration in response to the Independent Scientific Review Panel.

Contor, C.R. and P. Kissner. 2000. Umatilla basin natural production monitoring and evaluation. Annual progress report 1997-1998. Prepared for Bonneville Power Administration, Portland, Oregon.

Close, D.A. 2002. Pacific lamprey research and restoration project: annual report 2000. Prepared by the Confederated Tribes of the Umatilla Indian Reservation for the Bonneville Power Administration, Portland, Oregon.

Close, D.A., M.S. Fitzpatrick, and H.W. Li. 2002. The ecological and cultural importance of a species at risk of extinction, Pacific lamprey. Fisheries 27:19-25.

Collis, K., D.D. Roby, D.P. Craig, B.A. Ryan, and R.D. Ledgerwood. 2001. Colonial waterbird predation on juvenile salmonids tagged with passive integrated transponders in the Columbia River estuary: vulnerability of different salmonid species, stocks, and rearing types. Transactions of the American Fisheries Society 130:385-396.

Contor, C.R., E. Hoverson, P. Kissner, and J. Volkman. 1996. Umatilla basin natural production monitoring and evaluation: annual progress report 1994-1995. Confederated Tribes of the Umatilla Indian Reservation report to Bonneville Power Administration, Portland, Oregon.

CTUIR (Confederated Tribes of the Umatilla Indian Reservation) and ODFW (Oregon Department of Fish and Wildlife). 1989. Umatilla River subbasin - salmon and steelhead plan. Prepared for the Northwest Power Planning Council for Columbia basin system planning. 
Dauble, D.D., J. Skalski, A. Hoffman, and A. E. Giorgi. 1993. Evaluation and application of statistical methods for estimating smolt survival. Report to the Bonneville Power Administration, Portland, Oregon.

Efron, B. and R. Tibshirani. 1986. Bootstrap methods for standard errors, confidence intervals, and other measures of statistical accuracy. Statistical Science 1(1): 54-77.

Ehlers, D.L., S.M. Knapp, S.M. Jewett, and R.W. Carmichael. 2001. Evaluation of juvenile salmonid outmigration and survival in the lower Umatilla River basin. 1998-1999 annual progress report. Annual progress report 1998-1999 prepared by the Oregon Department of Fish and Wildlife for the Bonneville Power Administration, Portland, Oregon.

Ewing, R.D., S.L. Johnson, H.J. Pribble, and J.A. Lichatowich. 1979. Temperature and photoperiod effects on gill $(\mathrm{Na}+\mathrm{K})$-ATPase activity in chinook salmon (Oncorhynchus tshawytscha). Journal of the Fisheries Research Board of Canada 36:1347-1353.

Ewing, R.D., H.J. Pribble, S.L. Johnson, C.A. Fustich, J. Diamond, and J.A. Lichatowich. 1980. Influence of size, growth rate, and photoperiod on cyclic changes in gill $(\mathrm{Na}+\mathrm{K})-$ ATPase activity in chinook salmon (Oncorhynchus tshawytscha). Canadian Journal of Fisheries and Aquatic Sciences 37:600-605.

Ewing, R.D., C.E. Hart, C.A. Fustish, and G. Concannon. 1984. Effects of size and time of release on seaward migration of spring chinook salmon, Oncorhynchus tshawytscha. Fishery Bulletin 82:157-164.

Gallinat, M.P., J. Bumgarner, L. Ross, and M. Varney. 2001. Tucannon River spring chinook salmon hatchery evaluation program: annual report 2000. Washington Department of Fish and Wildlife report to the United States Fish and Wildlife Service. Report No. FPA01-05.

Giannico G.R. and M.C. Healey. 1997. Effects of Flow and Food on Winter Movements of Juvenile Coho Salmon. Transactions of the American Fisheries Society 127:645-651.

Groberg, W.J., Jr. and S.T. Onjukka. 1992. Fish Health Monitoring: Beyond the Raceway. Proceedings of a Technical Workshop on Passage and Survival of Juvenile Chinook Salmon Migrating from the Snake River Basin. University of Idaho, February 26-28, 1992.

Healey, M.C. 1991. Life history of chinook salmon. Pages 311-393 in C. Groot and L. Margolis, editors. Pacific salmon life histories. University of British Columbia Press, Vancouver.

Hoar, W.S. 1976. Smolt transformation: evolution, behavior, and physiology. Journal of the Fisheries Research Board of Canada 33:1233-1252. 
Hoar, W.S. 1988. The physiology of smolting salmonids. Pages 275-344 in W.S. Hoar and D.J. Randall, editors. Fish physiology, volume 11. The physiology of developing fish, part B. Academic Press, San Diego, California.

Knapp, S.M., J.C. Kern, W.A. Cameron, S.L. Shapleigh, and R.W. Carmichael. 1996. Evaluation of juvenile salmonid outmigration and survival in the lower Umatilla River basin. Annual progress report 1994-1995 prepared by the Oregon Department of Fish and Wildlife for the Bonneville Power Administration, Portland, Oregon.

Knapp, S.M., J.C. Kern, W.A. Cameron, S.M. Snedaker, and R.W. Carmichael. 1998a. Evaluation of juvenile salmonid outmigration and survival in the lower Umatilla River basin. Annual progress report 1995-1996 prepared by the Oregon Department of Fish and Wildlife for the Bonneville Power Administration, Portland, Oregon.

Knapp, S.M., W.A. Cameron, J.C. Kern, and R.W. Carmichael. 1998b. Evaluation of juvenile salmonid outmigration and survival in the lower Umatilla River basin. Annual progress report 1996-1997 prepared by the Oregon Department of Fish and Wildlife for the Bonneville Power Administration, Portland, Oregon.

Knapp, S.M., D.L. Ehlers, S.M. Focher, T.A. Jones, and J.C. Kern, and R.W. Carmichael. 2000. Evaluation of juvenile salmonid outmigration and survival in the lower Umatilla River basin. Annual progress report 1997-1998 prepared by the Oregon Department of Fish and Wildlife for the Bonneville Power Administration, Portland, Oregon.

Knapp, S.M., D.L. Ehlers, S.M. Jewett, and R.W. Carmichael. 2002. Evaluation of juvenile salmonid outmigration and survival in the lower Umatilla River basin. Annual progress report 2000-2001 prepared by the Oregon Department of Fish and Wildlife for the Bonneville Power Administration, Portland, Oregon.

Maynard, D.J., T.A. Flagg and C.V.W. Mahnken. 1995. A review of seminatural culture strategies for enhancing the postrelease survival of anadromous salmonids. American Fisheries Society Symposium 15:307-314.

McCormick, S.D., L.P. Hansen, T.P. Quinn, and R.L. Saunders. 1998. Movement, migration, and smolting of Atlantic salmon (Salmo salar). Canadian Journal of Fisheries and Aquatic Sciences 55:77-92.

Moore, D.S. and G.P.McCabe. 2002. Introduction to the Practice of Statistics, $4^{\text {th }}$ Edition. W.H. Freeman ad Company, New York.

NPPC (Northwest Power Planning Council). 1984, 1987, 1994. Columbia River Basin Fish and Wildlife Program, Portland, Oregon.

ODFW and CTUIR. 2000. Umatilla hatchery and basin annual operation plan: for the period of October 1, 2000 - September 30, 2001. Oregon Department of Fish and Wildlife and the Confederated Tribes of the Umatilla Indian Reservation report to Bonneville Power Administration, Portland, Oregon. 
Onjukka, S.T. 2001. ODFW Memorandum, February 9, 2001

Onjukka, S.T. 2001. Umatilla Fish Health Monitoring and Evaluation, Fish Pathology Quarterly Report, February - April 2001. Prepared for Bonneville Power Administration.

Onjukka, S.T. 2002. Personnal communication.

Quinn, T.P. and D.J. Adams. 1996. Environmental changes affecting the migratory timing of American shad and sockeye salmon. Ecology 77:1151-1162.

Reynolds, W.W. 1977. Temperature as a proximate factor in orientation behavior. Journal of the Fisheries Research Board of Canada 34:734-739.

Robards, M.D. and T.P. Quinn. 2002. The migratory timing of adult summer-run steelhead in the Columbia Rive over six decades of environmental change. Transactions of the American Fisheries Society 131:523-536.

Roper, B.B. and D.L. Scarnecchia. 1999. Emigration of age-0 chinook salmon (Oncorhynchus tshawytscha) smolts from the upper South Umpqua River basin, Oregon, U.S.A. Canadian Journal of Fisheries and Aquatic Sciences 56:939-946.

SAS Institute, Inc. 1990. SAS language: reference, version 6.12. Cary, North Carolina.

Saul, D., C. Rabe, A. Davidson, and D. Rollins. 2001. Umatilla Subbasin Summary - Draft. Prepared for the Northwest Power Planning Council for the Columbia Plateau Rolling Provincial Review, August 2001.

Schuck, M.L., A.E. Viola, and M.K. Keller. 1995. Lyons Ferry trout evaluation study: annual report 1993 - 1994. Washington Department of Fish and Wildlife report to the United States Fish and Wildlife Service. Report No. H95-06.

Schuck, M.L., A.E. Viola, and J. Dedloff. 1997. Lyons Ferry trout evaluation study: annual report 1995 - 1996. Washington Department of Fish and Wildlife report to the United States Fish and Wildlife Service. Report No. H97-08.

Smith, S.G., W.D. Muir, J.G. Williams, and J.R. Skalski. 2002. Factors associated with travel time and survival of migrant yearling chinook salmon and steelhead in the lower Snake River. North American Journal of Fisheries Management 22:385-405.

Sokal, R. and F.J. Rohlf. 2001. Biometry, 3rd Edition. W.H. Freeman and Company, New York.

Stonecypher, R.W. 2002. Personnal Communication.

Taylor, G. H. 1993. Normal annual precipitation, State of Oregon. Period 1961-1990. Map. Oregon climate Service, Oregon State University, Corvallis Oregon. 
Thedinga, J.F., M.L. Murphy, S.W. Johnson, J.M. Lorenz, and K.V. Koski. 1994. Determination of smolt yield with rotary-screw traps in the Situk River, Alaska, to predict effects of glacial flooding. North American Journal of Fisheries Management 14:837-851.

Tiffan, D.F., D.W. Rondorf, and P.G. Wagner. 2000. Physiological development and migratory behavior of subyearling fall chinook salmon in the Columbia River. North American Journal of Fisheries Management 20:28-40.

Torretta, G. 2000. Draft. Biological assessment of effects to multiple listed salmonid species from continued operations and maintenance of the Umatilla project and Umatilla basin project. Supplemental to the December, 1999 biological assessment on the federal Columbia River power system. United States Bureau of Reclamation report to the National Marine Fisheries Service and United States Fish and Wildlife Service.

U.S. Geological Survey (USGS). 1989. Hydrological unit map, State of Oregon. U.S. Geological Survey, Reston, Virgina.

Whalen, K.G., D.L. Parrish, and S.D. McCormick. 1999. Migration timing of Atlantic salmon smolts relative to environmental and physiological factors. Transactions of the American Fisheries Society 128:289-301.

Wedemeyer, G.A., R.L. Saunders, and W.C. Clarke. 1980. Environmental factors affecting smoltification and early marine survival of anadromous salmonids. United States National Marine Fisheries Service Marine Fisheries Review 42:1-14.

Zimmerman, B. and Bill Duke. 2000. Umatilla River Fish Passage Operations Program, Annual Progress Report, October 1999-September 2000. Prepared for Bonneville Power Administration by Confederated Tribes of the Umatilla Indian Reserve and the Oregon Department of Fish and Wildlife.

Zimmerman, B. and B. Duke. 2001. Umatilla River Fish Passage Operations Program, Annual Progress Report, October 2000-September 2001. Prepared for Bonneville Power Administration by Confederated Tribes of the Umatilla Indian Reserve and the Oregon Department of Fish and Wildlife.

Zimmerman, B. 2002. Umatilla River Fish Passage Operations Program, Monthly Report, Historical Data, November 2002. 
Table 1. Comparison of various hatchery, rearing, acclimation and release strategies in 2001, Umatilla River.

\begin{tabular}{|c|c|c|c|c|c|}
\hline $\begin{array}{l}\text { Hatchery, } \\
\text { Raceway }\end{array}$ & $\begin{array}{l}\text { Rearing } \\
\text { strategy }\end{array}$ & $\begin{array}{c}\text { Acclimation } \\
\text { site }^{c}\end{array}$ & $\begin{array}{c}\text { Acclimation } \\
\text { period }\end{array}$ & $\begin{array}{c}\text { Release } \\
\text { site }\end{array}$ & $\begin{array}{c}\text { Release } \\
\text { type/period }\end{array}$ \\
\hline \multicolumn{6}{|c|}{ Spring Chinook Salmon } \\
\hline \multicolumn{6}{|c|}{ Umatilla Fish Hatchery } \\
\hline O4A & Oregon & IC-2 & 6 weeks & RM 80 & Early (Mar) \\
\hline $\mathrm{O} 4 \mathrm{~B}$ & Oregon & IC-2 & 6 weeks & RM 80 & Early (Mar) \\
\hline O5A & Oregon & IC-1 & 16 weeks & RM 80 & Early (Mar) \\
\hline O5B & Oregon & IC-1 & 16 weeks & RM 80 & Early (Mar) \\
\hline M1A & Michigan & IC-3 & 6 weeks & RM 80 & Early (Mar) \\
\hline M1B & Michigan & IC-3 & 6 weeks & RM 80 & Early (Mar) \\
\hline M1C & Michigan & IC-3 & 6 weeks & RM 80 & Early (Mar) \\
\hline \multicolumn{6}{|c|}{ Little White Salmon Fish Hatchery } \\
\hline $39-43$ & Standard & IC-4 & 4 weeks & RM 80 & Early (Mar) \\
\hline $34-38$ & Standard & IC-4 & 4 weeks & RM 80 & Late (Apr) \\
\hline \multicolumn{6}{|c|}{ Carson National Fish Hatchery } \\
\hline $37-40$ & Standard & IC-3 & 4 weeks & RM 80 & Late (Apr) \\
\hline
\end{tabular}

Yearling Fall Chinook Salmon

Bonneville Fish Hatchery

$\begin{array}{llllll}\text { A7-11 } & \text { Standard } & \text { TH-1,2 } & \text { 4 weeks } & \text { RM 73.5 } & \text { Early (Mar) } \\ \text { A2-6 } & \text { Standard } & \text { TH-1,2 } & \text { 4 weeks } & \text { RM 73.5 } & \text { Late (Apr) }\end{array}$

Umatilla Fish Hatchery

$01 \mathrm{~A}$

$01 \mathrm{~B}$

$02 \mathrm{~A}$

$02 \mathrm{~B}$

Subyearling Fall Chinook Salmon

$\begin{array}{lcc}\text { Oregon } & \text { TH-2 } & 2 \text { weeks } \\ \text { Oregon } & \text { TH-2 } & 2 \text { weeks } \\ \text { Oregon } & \text { NA } & \text { None }^{d} \\ \text { Oregon } & \text { NA } & \text { None }^{\text {d }}\end{array}$

$\begin{array}{ll}\text { RM 73.5 } & \text { Single (May) } \\ \text { RM 73.5 } & \text { Single (May) } \\ \text { RM 48.5 } & \text { Single (May) } \\ \text { RM 48.5 } & \text { Single (May) }\end{array}$

\footnotetext{
${ }_{a}$ Oregon $=$ reared in standard non-oxygenated raceways; Michigan = reared in super-oxygenated raceways; Standard $=$ equivalent to Oregon raceways.

${ }^{b} \quad$ Standard - Lg = standard reared, large-grade summer steelhead; Standard-Sm = standard reared, small-grade summer steelhead.

$c \quad \mathrm{IC}=$ Imeques acclimation facility; $\mathrm{TH}=$ Thornhollow acclimation facility; $\mathrm{NA}=$ Not acclimated (direct stream released); $\mathrm{MN}=$ Minthorn acclimation facility; $\mathrm{BS}=$ Bonifer Springs acclimation facility; $\mathrm{PE}=$ Pendleton acclimation facility.

${ }^{d}$ None $=$ direct stream released .

$e$ Rivermile 2 of Meacham Creek, which flows into RM 79 of the Umatilla River.
} 


\begin{tabular}{|c|c|c|c|c|c|}
\hline $\begin{array}{l}\text { Hatchery, } \\
\text { Raceway }\end{array}$ & $\begin{array}{l}\text { Rearing } \\
\text { strategy }^{\text {a }}\end{array}$ & $\begin{array}{c}\text { Acclimation } \\
\text { site }^{c}\end{array}$ & $\begin{array}{c}\text { Acclimation } \\
\text { period }\end{array}$ & $\begin{array}{l}\text { Release } \\
\text { site }\end{array}$ & $\begin{array}{c}\text { Release } \\
\text { type/period }\end{array}$ \\
\hline \multicolumn{6}{|c|}{ Summer Steelhead } \\
\hline \multicolumn{6}{|c|}{ Umatilla Fish Hatchery } \\
\hline M8B & Standard $-\mathrm{Lg}^{\mathrm{b}}$ & $\mathrm{MN}-1,2$ & 4 weeks & RM 64.5 & Early (Mar) \\
\hline $\mathrm{M} 8 \mathrm{C}$ & Standard - Lg & BS-1 & 4 weeks & $\mathrm{RM} 79^{\mathrm{e}}$ & Early (Mar) \\
\hline M8A & Standard $-\mathrm{Sm}^{\mathrm{b}}$ & $\mathrm{MN}-1,2$ & 3 weeks & RM 64.5 & Late (Apr) \\
\hline $\mathrm{MAC}^{\mathrm{c}}$ & Standard $-\mathrm{Sm}^{\mathrm{b}}$ & $\mathrm{MN}-1,2$ & 4 weeks & RM 64.5 & Early (Mar) \\
\hline $\mathrm{MAB}^{\mathrm{c}}$ & Standard $-\mathrm{Sm}^{\mathrm{b}}$ & BS-1 & 4 weeks & $\mathrm{RM} 79^{\mathrm{e}}$ & Early (Mar) \\
\hline \multicolumn{6}{|c|}{ Coho Salmon } \\
\hline \multicolumn{6}{|c|}{ Cascade Fish Hatchery } \\
\hline $1-4$ & Standard & PE1 & 4 weeks & RM 56 & Early (Mar) \\
\hline $21-30$ & Standard & PE2 & 4 weeks & RM 56 & Late (Apr) \\
\hline $21-30$ & Standard & $\mathrm{P} 22$ & 4 weeks & RM 56 & Late (Apr) \\
\hline \multicolumn{6}{|c|}{ Herman Creek Fish Hatchery } \\
\hline L1-L2 & Standard & PE3 & 4 weeks & RM 56 & Early (Mar) \\
\hline
\end{tabular}


Table 2. Actual and adjusted sample numbers of juvenile salmonids at RM 1.2 and 3.7, Umatilla River, October 2000 - September 2001.

\begin{tabular}{|c|c|c|c|}
\hline Species $^{a}$ & Age & Number sampled & Adjusted sample ${ }^{b}$ \\
\hline \multicolumn{4}{|c|}{ RM $1.2(10 / 02 / 00-03 / 08 / 01)$} \\
\hline $\mathrm{HCH}$ & $1+$ & 2 & 2 \\
\hline HCHS & $1+$ & 8 & 8 \\
\hline $\mathrm{NCH}$ & $1+$ & 28 & 73 \\
\hline $\mathrm{NCOH}$ & $1+$ & 7 & 45 \\
\hline NSTS & $0-3+$ & 1 & 1 \\
\hline Total & & 46 & 129 \\
\hline \multicolumn{4}{|c|}{ RM 3.7 (03/09/01 - 09/28/01) } \\
\hline $\mathrm{HCH}$ & $1+$ & 1,253 & 1,791 \\
\hline HCHS & $1+$ & 2,483 & 3,600 \\
\hline HCHF & $1+$ & 3,496 & 4,889 \\
\hline HCHF & $0+$ & 4,398 & 4,417 \\
\hline $\mathrm{HCOH}$ & $1+$ & 1,032 & 1,348 \\
\hline HSTS & $1+$ & 2,050 & 2,871 \\
\hline $\mathrm{NCH}$ & $0-1+$ & 1,724 & 1,799 \\
\hline $\mathrm{NCOH}$ & $0-1+$ & 214 & 242 \\
\hline NSTS & $0-3+$ & 846 & 1,088 \\
\hline $\mathrm{UCOH}$ & $0-1+$ & 16,351 & 20,294 \\
\hline Total & & 33,847 & 42,339 \\
\hline
\end{tabular}

a $\mathrm{HCH}=$ hatchery chinook salmon of unknown race, $\mathrm{HCHS}=$ hatchery spring chinook salmon, $\mathrm{NCH}=$ natural chinook salmon of unknown race, $\mathrm{NCOH}=$ natural coho, $\mathrm{NSTS}=$ natural steelhead, $\mathrm{HCHF}=$ hatchery fall chinook salmon, $\mathrm{HCOH}=$ hatchery coho, $\mathrm{HSTS}=$ hatchery steelhead, $\mathrm{UCOH}=$ natural and unmarked hatchery coho.

${ }^{b}$ Adjusted number sampled is the number of fish sampled, adjusted by the amount of time not sampled at RM 1.2 and by a given sample rate utilized during a specific sample period at RM 3.7. 
Table 3. PIT-tagged production fish from various hatchery, rearing, and release strategies detected at West Extension Canal, RM 3.7, Umatilla River, March - September 2001.

\begin{tabular}{|c|c|c|c|c|c|c|c|c|}
\hline \multirow{2}{*}{$\begin{array}{l}\text { Hatchery, } \\
\text { rearing } \\
\text { strategy }^{a}\end{array}$} & \multirow[b]{2}{*}{ Raceway } & \multirow{2}{*}{$\begin{array}{l}\text { Number } \\
\text { released }\end{array}$} & \multirow{2}{*}{$\begin{array}{c}\text { Release }^{b} \\
\text { date }\end{array}$} & \multicolumn{4}{|c|}{ Number detected } & \multirow{2}{*}{$\begin{array}{c}\text { Percent } \\
\text { detection }\end{array}$} \\
\hline & & & & Ladder & Hand & Remote & Total & \\
\hline \multicolumn{9}{|c|}{ Spring Chinook Salmon } \\
\hline \multicolumn{9}{|c|}{ Umatilla Fish Hatchery } \\
\hline Oregon & $\mathrm{O} 4 \mathrm{~A}$ & 294 & $3 / 3-9$ & 0 & 0 & 25 & 25 & 8.5 \\
\hline $\begin{array}{c}\text { Oregon } \\
\text { Total }\end{array}$ & O4B & 299 & 3/3-9 & 0 & 0 & 29 & 29 & $\begin{array}{l}9.7 \\
9.1\end{array}$ \\
\hline Oregon & $05 \mathrm{~A}^{c}$ & 298 & $3 / 3-9$ & 0 & 0 & 22 & 22 & 7.4 \\
\hline $\begin{array}{c}\text { Oregon } \\
\text { Total }\end{array}$ & ${\mathrm{O} 5 \mathrm{~B}^{c}}^{c}$ & 295 & $3 / 3-9$ & 0 & 3 & 25 & 28 & $\begin{array}{l}9.5 \\
8.4\end{array}$ \\
\hline Michigan & M1A & 280 & $3 / 3-9$ & 0 & 1 & 27 & 28 & 10.0 \\
\hline Michigan & M1B & 290 & $3 / 3-9$ & 0 & 0 & 24 & 24 & 8.3 \\
\hline $\begin{array}{l}\text { Michigan } \\
\text { Total }\end{array}$ & M1C & 293 & $3 / 3-9$ & 0 & 0 & 26 & 26 & $\begin{array}{l}8.9 \\
9.0\end{array}$ \\
\hline \multicolumn{9}{|c|}{ Little White Salmon Fish Hatchery } \\
\hline Standard & $39-43$ & 289 & $3 / 10-16$ & 0 & 0 & 1 & 1 & 0.3 \\
\hline $\begin{array}{c}\text { Standard } \\
\text { Total }\end{array}$ & $34-38$ & 286 & $4 / 11-17$ & 0 & 0 & 17 & 17 & $\begin{array}{l}5.9 \\
3.1\end{array}$ \\
\hline \multicolumn{9}{|c|}{ Carson National Fish Hatchery } \\
\hline $\begin{array}{c}\text { Standard } \\
\text { Total }\end{array}$ & $37-40$ & 288 & $4 / 11-17$ & 0 & 0 & 11 & 11 & $\begin{array}{l}3.8 \\
3.8\end{array}$ \\
\hline \multicolumn{9}{|c|}{ Yearling Fall Chinook Salmon } \\
\hline Bonneville & h Hatchery & & & & & & & \\
\hline Standard & A7-11 & 271 & $3 / 10-16$ & 0 & 1 & 14 & 15 & 5.5 \\
\hline $\begin{array}{c}\text { Standard } \\
\text { Total } \\
\end{array}$ & A2-6 & 295 & $4 / 13-19$ & 0 & 0 & 61 & 61 & $\begin{array}{l}20.7 \\
13.4\end{array}$ \\
\hline 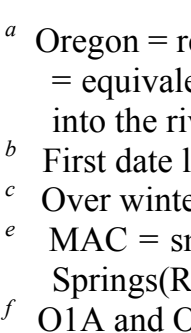 & $\begin{array}{l}\text { d in standard } \\
\text { o Oregon rac } \\
\text { = volitional } \\
\text { at the Imeque } \\
\text {-grade test fis } \\
\text { of Meacham } \\
=\text { acclimated }\end{array}$ & $\begin{array}{l}\text { on-oxygenat } \\
\text { vays; Acclir } \\
\text { lease date, } \\
\text { (RM 80) ac } \\
\text { released at } \\
\text { reek. }\end{array}$ & $\begin{array}{l}\text { d raceways; } \\
\text { ted = acclim } \\
\text { cond date list } \\
\text { imation facili } \\
\text { Ginthorn (RM }\end{array}$ & $\begin{array}{l}\text { lichigan }= \\
\text { th }=\text { forced } \\
\text { ty. } \\
64.5 \text { ); MA }\end{array}$ & $\begin{array}{l}\text { eared in } \\
\text { se site, a } \\
\text { release c } \\
B=\text { sma }\end{array}$ & $\begin{array}{l}\text { uper-oxyge } \\
\text { d Direct S } \\
\text { te. } \\
\text {-grade tes }\end{array}$ & $\begin{array}{ll}\mathrm{edrace} \\
m=\mathrm{re}\end{array}$ & $\begin{array}{l}\text { ay; Standard } \\
\text { ased directly } \\
\text { d at Bonifer }\end{array}$ \\
\hline
\end{tabular}


Table 3. Continued.

\begin{tabular}{|c|c|c|c|c|c|c|c|c|}
\hline \multirow{2}{*}{$\begin{array}{l}\text { Hatchery, } \\
\text { rearing }^{a} \\
\text { strategy }\end{array}$} & \multirow[b]{2}{*}{ Pond } & \multirow{2}{*}{$\begin{array}{l}\text { Number } \\
\text { released }\end{array}$} & \multirow{2}{*}{$\begin{array}{c}\text { Release }^{b} \\
\text { date }\end{array}$} & \multicolumn{4}{|c|}{ Number detected } & \multirow{2}{*}{$\begin{array}{l}\text { Percent } \\
\text { detection }\end{array}$} \\
\hline & & & & Ladder & Hand & Remote & Total & \\
\hline \multicolumn{9}{|c|}{ Subyearling Fall Chinook Salmon } \\
\hline \multicolumn{9}{|c|}{ Umatilla Fish Hatchery } \\
\hline Oregon & $01 \mathrm{~A}^{d}$ & 290 & $5 / 21-24$ & 2 & 4 & 110 & 116 & 40.0 \\
\hline Oregon & $01 \mathrm{~B}^{d}$ & 292 & $5 / 21-24$ & 3 & 10 & 114 & 127 & 43.5 \\
\hline Total & & & & & & & & 41.7 \\
\hline Oregon & $02 \mathrm{~A}^{d}$ & 290 & $5 / 25$ & 3 & 4 & 102 & 109 & 37.6 \\
\hline Oregon & $02 \mathrm{~B}^{d}$ & 300 & $5 / 24$ & 3 & 4 & 95 & 102 & 34.0 \\
\hline Total & & & & & & & & 35.8 \\
\hline \multicolumn{9}{|c|}{ Coho Salmon } \\
\hline \multicolumn{9}{|c|}{ Cascade Fish Hatchery } \\
\hline Standard & $1-4$ & 291 & $3 / 15$ & 1 & 2 & 14 & 17 & 5.8 \\
\hline Standard & $21-30$ & 294 & $4 / 18-24$ & 0 & 5 & 37 & 42 & 14.3 \\
\hline Standard & $21-30$ & 297 & $4 / 18-24$ & 0 & 3 & 35 & 38 & 12.8 \\
\hline Total & & & & & & & & 11.0 \\
\hline \multicolumn{9}{|c|}{ Herman Creek Fish Hatchery } \\
\hline Standard & L1-L2 & 296 & $3 / 15$ & 0 & 1 & 6 & 7 & 2.4 \\
\hline Total & & & & & & & & 2.4 \\
\hline \multicolumn{9}{|c|}{ Summer Steelhead } \\
\hline Umatilla Fish & tchery & & & & & & & \\
\hline Large grade & $\mathrm{M} 8 \mathrm{C}$ & 282 & $3 / 28-4 / 4$ & 4 & 4 & 34 & 42 & 14.9 \\
\hline Large grade & M8B & 296 & $3 / 31-4 / 6$ & 4 & 4 & 28 & 36 & 12.2 \\
\hline Small grade & M8A & 581 & $4 / 23-26$ & 3 & 5 & 46 & 54 & 9.3 \\
\hline Small grade & $\mathrm{MAC}^{e}$ & 586 & $3 / 28-4 / 4$ & 4 & 6 & 47 & 57 & 9.7 \\
\hline Small grade & $\mathrm{MAB}^{e}$ & 577 & $3 / 31-4 / 6$ & 4 & 0 & 24 & 28 & 4.9 \\
\hline Total & & & & & & & & 9.3 \\
\hline
\end{tabular}


Table 4. Natural fish PIT tagged by CTUIR in the upper Umatilla River and detected at West Extension Canal, RM 3.7, Umatilla River, March - September 2001.

\begin{tabular}{|c|c|c|c|c|c|}
\hline \multirow{2}{*}{$\begin{array}{l}\begin{array}{l}\text { Release } \\
\text { site }\end{array} \\
\end{array}$} & \multirow{2}{*}{$\begin{array}{l}\text { Release } \\
\text { month }\end{array}$} & \multirow{2}{*}{$\begin{array}{l}\text { Number } \\
\text { tagged }\end{array}$} & \multicolumn{3}{|c|}{ Number detected } \\
\hline & & & Ladder & Hand & Remote \\
\hline
\end{tabular}

\section{Chinook Salmon}

\begin{tabular}{|c|c|c|c|c|c|c|c|}
\hline \multirow{8}{*}{$\begin{array}{l}\text { Umatilla River } \\
\text { (RM 80) }\end{array}$} & Oct 2000 & 86 & 0 & 0 & 1 & 1 & 1.2 \\
\hline & Nov 2000 & 550 & 0 & 1 & 13 & 14 & 2.5 \\
\hline & Dec 2000 & 171 & 0 & 1 & 2 & 3 & 1.8 \\
\hline & Jan 2001 & 45 & 0 & 0 & 0 & 0 & 0.0 \\
\hline & Feb 2001 & 82 & 0 & 0 & 6 & 6 & 7.3 \\
\hline & Mar 2001 & 597 & 0 & 3 & 41 & 44 & 7.4 \\
\hline & Apr 2001 & 15 & 0 & 1 & 5 & 6 & 40.0 \\
\hline & May 2001 & 1 & 0 & 0 & 0 & 0 & 0.0 \\
\hline Total & & 1,547 & & & & 74 & 4.8 \\
\hline Meacham & Nov 2000 & 29 & 0 & 0 & 0 & 0 & 0.0 \\
\hline (RM 79) & Dec 2000 & 39 & 0 & 0 & 0 & 0 & 0.0 \\
\hline & Jan 2001 & 2 & 0 & 0 & 0 & 0 & 0.0 \\
\hline & Feb 2001 & 11 & 0 & 0 & 0 & 0 & 0.0 \\
\hline & Mar 2001 & 44 & 0 & 0 & 1 & 1 & 2.3 \\
\hline Total & & 125 & & & & 1 & 0.8 \\
\hline Squaw Creek & Jan 2001 & 5 & 0 & 0 & 2 & 2 & 40.0 \\
\hline (RM 77) & Feb 2001 & 1 & 0 & 0 & 0 & 0 & 0.0 \\
\hline Total & & 6 & & & & 2 & 33.3 \\
\hline
\end{tabular}

\section{Coho Salmon}

$\begin{array}{llllllll}\text { Umatilla River } & \text { Nov 2000 } & 148 & 0 & 1 & 1 & 2 & 1.4 \\ \text { (RM 80) } & \text { Dec 2000 } & 103 & 0 & 0 & 1 & 1 & 1.0 \\ \text { Total } & & 251 & & & & 3 & 1.2\end{array}$

\section{Summer Steelhead}

\begin{tabular}{lccc} 
Umatilla River & Oct 2000 & 6 & 0 \\
(RM 80) & Nov 2000 & 24 & 0 \\
& Dec 2000 & 62 & 0 \\
& Jan 2001 & 1 & 0 \\
& Feb 2001 & 38 & 0 \\
& Mar 2001 & 686 & 1 \\
& Apr 2001 & 116 & 1 \\
Total & May 2001 & 11 & 0 \\
\hline
\end{tabular}

${ }^{a}$ Number tagged is equivalent to number released. 
Table 4. Continued.

\begin{tabular}{|c|c|c|c|c|c|c|c|}
\hline \multirow{2}{*}{$\begin{array}{l}\text { Release } \\
\text { site }\end{array}$} & \multirow{2}{*}{$\begin{array}{l}\text { Release } \\
\text { month }\end{array}$} & \multirow{2}{*}{$\begin{array}{l}\text { Number } \\
\text { tagged }^{a}\end{array}$} & \multicolumn{3}{|c|}{ Number detected } & \multirow{2}{*}{$\begin{array}{c}\text { Total } \\
\text { detected }\end{array}$} & \multirow{2}{*}{$\begin{array}{c}\text { Percent } \\
\text { detection }\end{array}$} \\
\hline & & & Ladder & Hand & Remote & & \\
\hline \multicolumn{8}{|c|}{ Summer Steelhead } \\
\hline Meacham Creek & Nov 2000 & 26 & 0 & 0 & 1 & 1 & 3.8 \\
\hline (RM 79) & Dec 2000 & 24 & 0 & 0 & 1 & 1 & 4.2 \\
\hline & Jan 2001 & 1 & 0 & 0 & 0 & 0 & 0.0 \\
\hline & Feb 2001 & 93 & 1 & 0 & 5 & 6 & 6.5 \\
\hline & Mar 2001 & 845 & 6 & 3 & 41 & 50 & 5.9 \\
\hline Total & & 989 & & & & 58 & 5.9 \\
\hline Squaw Creek & Jan 2001 & 124 & 0 & 1 & 2 & 3 & 2.4 \\
\hline (RM 77) & Feb 2001 & 137 & 0 & 1 & 3 & 4 & 2.9 \\
\hline Total & & 261 & & & & 7 & 2.7 \\
\hline \multicolumn{8}{|c|}{ Birch Creek Tributaries (RM 48) } \\
\hline East Fork (RM 16) & Jan 2001 & 224 & 2 & 1 & 17 & 20 & 8.9 \\
\hline West Fork (RM 16) & Jan 2001 & 203 & 0 & 1 & 12 & 13 & 6.4 \\
\hline Total & & 427 & & & & 33 & 7.7 \\
\hline
\end{tabular}


Table 5. Percent holding survival and tag retention of hatchery and natural juvenile salmonids tagged for trap efficiency tests at West Extension Canal, RM 3.7, Umatilla River, spring 2001.

\begin{tabular}{|c|c|c|c|c|c|c|c|}
\hline $\begin{array}{l}\text { Mark } \\
\text { date }\end{array}$ & $\begin{array}{c}\text { Number } \\
\text { tagged }\end{array}$ & $\begin{array}{c}\text { Mean } \\
\text { temperature }\end{array}$ & $\begin{array}{c}\text { Hours } \\
\text { held }\end{array}$ & $\begin{array}{c}\text { Number } \\
\text { mortalities }\end{array}$ & $\begin{array}{c}\text { Number of } \\
\text { lost tags }\end{array}$ & $\begin{array}{l}\text { Percent } \\
\text { holding } \\
\text { survival }\end{array}$ & $\begin{array}{c}\text { Percent tag } \\
\text { retention }\end{array}$ \\
\hline \multicolumn{8}{|c|}{ Hatchery } \\
\hline $3 / 11$ & 100 & 9.5 & $24.7^{\circ}$ & 0 & 1 & 100.0 & 99.0 \\
\hline $3 / 13$ & 93 & 10.5 & 26.1 & 0 & 0 & 100.0 & 100.0 \\
\hline $3 / 16$ & 99 & 8.5 & 24.0 & 0 & 0 & 100.0 & 100.0 \\
\hline $3 / 22$ & 100 & 9.5 & 27.0 & 0 & 0 & 100.0 & 100.0 \\
\hline $4 / 4$ & 61 & 8.0 & 22.8 & 0 & 4 & 100.0 & 93.4 \\
\hline $4 / 10$ & 62 & 9.5 & 24.8 & 0 & 0 & 100.0 & 100.0 \\
\hline $4 / 16$ & 70 & 12.0 & 27.1 & 2 & 0 & 97.1 & 100.0 \\
\hline $4 / 21$ & 76 & 12.0 & 22.5 & 0 & 0 & 100.0 & 100.0 \\
\hline $4 / 29$ & 85 & 10.5 & 26.5 & 0 & 0 & 100.0 & 100.0 \\
\hline Total & 746 & & & & Overall & 99.7 & 99.3 \\
\hline \multicolumn{8}{|c|}{ Fall Chinook Salmon } \\
\hline $3 / 22$ & 98 & 9.5 & 27.6 & 0 & 0 & 100.0 & 100.0 \\
\hline $3 / 27$ & 92 & 8.5 & 27.5 & 0 & 0 & 100.0 & 100.0 \\
\hline $4 / 4$ & 95 & 8.0 & 23.8 & 0 & 2 & 100.0 & 97.9 \\
\hline $4 / 16$ & 65 & 12.0 & 27.8 & 1 & 0 & 98.5 & 100.0 \\
\hline $4 / 21$ & 75 & 12.0 & 25.5 & 0 & 0 & 100.0 & 100.0 \\
\hline $4 / 29$ & 100 & 10.5 & 25.3 & 1 & 0 & 99.0 & 100.0 \\
\hline $5 / 4$ & 75 & 13.0 & 25.2 & 0 & 0 & 100.0 & 100.0 \\
\hline $5 / 10$ & 50 & 17.5 & 24.9 & 0 & 0 & 100.0 & 100.0 \\
\hline $5 / 15$ & 35 & 15.5 & 21.8 & 0 & 0 & 100.0 & 100.0 \\
\hline $5 / 18$ & 31 & 16.3 & 22.4 & 1 & 0 & 96.8 & 100.0 \\
\hline Total & 716 & & & & Overall & 99.6 & 99.7 \\
\hline \multicolumn{8}{|c|}{ Subyearling Fall Chinook Salmon } \\
\hline $5 / 27$ & 75 & 21.0 & 30.8 & 1 & 0 & 98.7 & 100.0 \\
\hline $5 / 30$ & 74 & 19.3 & 24.0 & 0 & 0 & 100.0 & 100.0 \\
\hline $5 / 31$ & 75 & 20.0 & 23.3 & 0 & 0 & 100.0 & 100.0 \\
\hline $6 / 2$ & 75 & 16.5 & 23.3 & 0 & 0 & 100.0 & 100.0 \\
\hline $6 / 4$ & 75 & 14.8 & 28.5 & 0 & 0 & 100.0 & 100.0 \\
\hline $6 / 6$ & 50 & 18.3 & 25.3 & 0 & 0 & 100.0 & 100.0 \\
\hline 6/9 & 50 & 19.0 & 52.0 & 0 & 0 & 100.0 & 100.0 \\
\hline $6 / 14$ & 32 & 18.0 & 24.4 & 0 & 0 & 100.0 & 100.0 \\
\hline $6 / 17$ & 41 & 18.5 & 27.7 & 1 & 0 & 97.6 & 100.0 \\
\hline Total & 547 & & & & Overall & 99.6 & 100.0 \\
\hline
\end{tabular}


Table 5. Continued

\begin{tabular}{|c|c|c|c|c|c|c|c|}
\hline $\begin{array}{l}\text { Mark } \\
\text { date }\end{array}$ & $\begin{array}{l}\text { Number } \\
\text { held }\end{array}$ & $\begin{array}{c}\text { Mean } \\
\text { temperature }^{a}\end{array}$ & $\begin{array}{c}\text { Hours } \\
\text { held }\end{array}$ & $\begin{array}{c}\text { Number } \\
\text { mortalities }\end{array}$ & $\begin{array}{l}\text { Number of } \\
\text { lost tags }\end{array}$ & $\begin{array}{l}\text { Percent } \\
\text { Survival }\end{array}$ & $\begin{array}{l}\text { Percent tag } \\
\text { retention }\end{array}$ \\
\hline \multicolumn{8}{|c|}{ Summer Steelhead } \\
\hline $4 / 8$ & 142 & 7.8 & 24.8 & 0 & 5 & 100.0 & 96.5 \\
\hline $4 / 11$ & 148 & 9.0 & 26.3 & 0 & 0 & 100.0 & 100.0 \\
\hline $5 / 1$ & 101 & 10.3 & 26.0 & 0 & 2 & 100.0 & 98.0 \\
\hline $5 / 10$ & 29 & 18.3 & 24.2 & 0 & 0 & 100.0 & 100.0 \\
\hline $5 / 13$ & 31 & 16.5 & 29.0 & 0 & 0 & 100.0 & 100.0 \\
\hline $5 / 15$ & 23 & 15.5 & 24.2 & 0 & 0 & 100.0 & 100.0 \\
\hline $5 / 18$ & 40 & 16.3 & 22.7 & 0 & 0 & 100.0 & 100.0 \\
\hline $5 / 21$ & 27 & 17.3 & 23.0 & 1 & 0 & 96.3 & 100.0 \\
\hline $5 / 25$ & 53 & 22.8 & 29.7 & 7 & 0 & 86.8 & 100.0 \\
\hline $5 / 28$ & 34 & 19.0 & 25.0 & 0 & 0 & 100.0 & 100.0 \\
\hline $6 / 11$ & 31 & 16.0 & 24.0 & 0 & 0 & 100.0 & 100.0 \\
\hline Total & 659 & & & & Overall & 98.8 & 98.9 \\
\hline \multicolumn{8}{|c|}{$\begin{array}{c}\text { Unmarked } \\
\text { Coho Salmon }\end{array}$} \\
\hline $3 / 21$ & 100 & 9.0 & 23.5 & 0 & 0 & 100.0 & 100.0 \\
\hline $3 / 26$ & 100 & 9.8 & 26.8 & 0 & 0 & 100.0 & 100.0 \\
\hline $4 / 3$ & 102 & 7.5 & 26.7 & 0 & 0 & 100.0 & 100.0 \\
\hline $4 / 7$ & 94 & 8.0 & 51.5 & 0 & 0 & 100.0 & 100.0 \\
\hline $4 / 16$ & 90 & 12.0 & 26.3 & 0 & 0 & 100.0 & 100.0 \\
\hline $4 / 23$ & 70 & 12.0 & 27.0 & 0 & 0 & 100.0 & 100.0 \\
\hline $5 / 4$ & 75 & 13.0 & 24.5 & 0 & 1 & 100.0 & 98.7 \\
\hline $5 / 12$ & 50 & 17.8 & 27.0 & 0 & 0 & 100.0 & 100.0 \\
\hline $5 / 21$ & 75 & 17.3 & 25.0 & 0 & 0 & 100.0 & 100.0 \\
\hline Total & 756 & & & & Overall & 100.0 & 99.9 \\
\hline \multicolumn{8}{|c|}{$\begin{array}{c}\text { Natural } \\
\text { Chinook Salmon }\end{array}$} \\
\hline $6 / 5$ & 49 & 16.3 & 23.9 & 0 & 0 & 100.0 & 100.0 \\
\hline $6 / 6$ & 50 & 18.3 & 25.7 & 1 & 0 & 98.0 & 100.0 \\
\hline $6 / 11$ & 49 & 16.0 & 23.8 & 1 & 0 & 98.0 & 100.0 \\
\hline $6 / 14$ & 23 & 18.0 & 24.4 & 0 & 0 & 100.0 & 100.0 \\
\hline $6 / 17$ & 50 & 18.5 & 28.0 & 0 & 0 & 100.0 & 100.0 \\
\hline $6 / 25$ & 56 & 18.0 & 27.5 & 0 & 0 & 100.0 & 100.0 \\
\hline $6 / 29$ & 75 & 21.0 & 28.0 & 2 & 0 & 97.3 & 100.0 \\
\hline Total & 352 & & & & Overall & 98.9 & 100.0 \\
\hline
\end{tabular}


Table 5. Continued

\begin{tabular}{|c|c|c|c|c|c|c|c|}
\hline $\begin{array}{l}\text { Mark } \\
\text { date }\end{array}$ & $\begin{array}{c}\text { Number } \\
\text { held }\end{array}$ & $\begin{array}{c}\text { Mean } \\
\text { temperature }^{a}\end{array}$ & $\begin{array}{c}\text { Hours } \\
\text { held }\end{array}$ & $\begin{array}{c}\text { Number } \\
\text { mortalities }\end{array}$ & $\begin{array}{c}\text { Number of } \\
\text { lost tags }\end{array}$ & $\begin{array}{c}\text { Percent } \\
\text { survival }^{b}\end{array}$ & $\begin{array}{l}\text { Percent tag } \\
\text { retention }\end{array}$ \\
\hline \multicolumn{8}{|c|}{$\begin{array}{l}\text { Natural } \\
\text { ummer Steelhead }\end{array}$} \\
\hline $5 / 1$ & 73 & 10.3 & 27.0 & 0 & 0 & 100.0 & 100.0 \\
\hline $5 / 10$ & 6 & 18.3 & 24.2 & 0 & 0 & 100.0 & 100.0 \\
\hline $5 / 13$ & 8 & 16.5 & 29.0 & 0 & 0 & 100.0 & 100.0 \\
\hline $5 / 15$ & 14 & 15.5 & 24.2 & 0 & 0 & 100.0 & 100.0 \\
\hline $5 / 18$ & 40 & 16.3 & 23.0 & 0 & 0 & 100.0 & 100.0 \\
\hline $5 / 21$ & 44 & 17.3 & 23.5 & 0 & 0 & 100.0 & 100.0 \\
\hline $5 / 25$ & 46 & 22.8 & 28.4 & 5 & 0 & 89.1 & 100.0 \\
\hline $5 / 28$ & 45 & 19.0 & 24.2 & 0 & 0 & 100.0 & 100.0 \\
\hline $6 / 11$ & 8 & 16.0 & 24.0 & 0 & 0 & 100.0 & 100.0 \\
\hline Total & 284 & & & & Overall & 98.2 & 100.0 \\
\hline
\end{tabular}


Table 6. Trap efficiency estimates for hatchery and natural juvenile salmonids at West Extension Canal (RM 3.7), March - June 2001.

\begin{tabular}{|c|c|c|c|c|c|c|c|c|c|c|}
\hline \multirow{2}{*}{$\begin{array}{l}\text { Release } \\
\text { date }\end{array}$} & \multirow{2}{*}{$\begin{array}{l}\text { Number }^{a} \\
\text { released }\end{array}$} & \multirow{2}{*}{$\begin{array}{c}\text { Release } \\
\text { temp } \\
\left({ }^{\circ} \mathrm{C}\right)\end{array}$} & \multicolumn{5}{|c|}{$\begin{array}{l}\text { Number detected by } \\
\text { days after release }\end{array}$} & \multirow{2}{*}{$\begin{array}{c}\text { Mean } \\
\text { travel time } \\
\text { (days) }\end{array}$} & \multirow{2}{*}{$\begin{array}{c}\text { Trap } \\
\text { efficiency } \\
(\mathrm{TE})\end{array}$} & \multirow{2}{*}{$\begin{array}{c}\text { Pooled } \\
\mathrm{TE}^{b}\end{array}$} \\
\hline & & & $0-5$ & $6-10$ & $11-15$ & $16-20$ & $>20$ & & & \\
\hline \multicolumn{11}{|c|}{$\begin{array}{c}\text { Hatchery } \\
\text { Snring Chinek Salmon }\end{array}$} \\
\hline $3 / 12$ & 100 & 14.0 & 6 & 0 & 0 & 0 & 0 & 0.32 & 0.060 & 0.061 \\
\hline $3 / 14$ & 93 & 13.0 & 6 & 0 & 0 & 0 & 0 & 0.22 & 0.065 & 0.061 \\
\hline $3 / 17$ & 99 & 12.0 & 3 & 0 & 0 & 0 & 1 & 9.30 & 0.040 & 0.061 \\
\hline $3 / 23$ & 100 & 11.6 & 8 & 0 & 0 & 0 & 0 & 0.22 & 0.080 & 0.061 \\
\hline $4 / 5$ & 61 & 10.0 & 9 & 2 & 1 & 1 & 1 & 4.96 & 0.229 & 0.236 \\
\hline $4 / 11$ & 62 & 10.0 & 14 & 1 & 0 & 0 & 0 & 0.82 & 0.242 & 0.236 \\
\hline $4 / 17$ & 66 & 15.0 & 5 & 0 & 0 & 0 & 0 & 1.77 & 0.074 & 0.074 \\
\hline $4 / 22$ & 76 & 13.0 & 32 & 2 & 1 & 0 & 0 & 2.36 & 0.461 & 0.534 \\
\hline $4 / 30$ & 85 & 12.0 & 50 & 1 & 0 & 0 & 0 & 0.96 & 0.600 & 0.534 \\
\hline \multicolumn{11}{|c|}{ Mean pooled $T E=0.206(S D=0.188)$} \\
\hline
\end{tabular}

Fall Chinook Salmon

$\begin{array}{lcccccccccc}3 / 23 & 98 & 11.6 & 19 & 0 & 1 & 1 & 1 & 4.98 & 0.224 & 0.260 \\ 3 / 28 & 92 & 10.2 & 21 & 2 & 3 & 2 & 1 & 4.54 & 0.315 & 0.260 \\ 4 / 5 & 95 & 10.0 & 15 & 2 & 3 & 2 & 1 & 5.57 & 0.242 & 0.260 \\ 4 / 17 & 63 & 15.0 & 5 & 0 & 0 & 0 & 0 & 1.49 & 0.078 & 0.078 \\ 4 / 22 & 75 & 13.0 & 15 & 5 & 0 & 0 & 0 & 3.67 & 0.266 & 0.299 \\ 4 / 30 & 98 & 12.0 & 26 & 6 & 0 & 0 & 0 & 2.07 & 0.323 & 0.299 \\ 5 / 5 & 75 & 15.0 & 11 & 0 & 0 & 0 & 0 & 1.77 & 0.147 & 0.147 \\ 5 / 11 & 50 & 18.0 & 26 & 0 & 0 & 0 & 0 & 0.98 & 0.520 & 0.487 \\ 5 / 16 & 35 & 16.5 & 17 & 0 & 0 & 0 & 0 & 1.36 & 0.485 & 0.487 \\ 5 / 19 & 29 & 17.0 & 13 & 0 & 0 & 0 & 0 & 0.67 & 0.433 & 0.487 \\ & & & & & & & & & & \\ & & & & & & & & & & \end{array}$

Subyearling Fall Chinook Salmon

$\begin{array}{lllllllllll}5 / 28 & 73 & 18.0 & 43 & 0 & 0 & 0 & 0 & 0.26 & 0.581 & 0.343 \\ 5 / 31 & 74 & 19.0 & 27 & 0 & 0 & 0 & 0 & 1.00 & 0.365 & 0.343 \\ 6 / 1 & 75 & 18.5 & 19 & 1 & 1 & 0 & 0 & 1.09 & 0.280 & 0.343 \\ 6 / 3 & 75 & 17.0 & 18 & 0 & 0 & 1 & 0 & 0.83 & 0.253 & 0.343 \\ 6 / 5 & 75 & 16.0 & 17 & 1 & 0 & 0 & 0 & 0.76 & 0.240 & 0.343 \\ 6 / 7 & 50 & 18.0 & 6 & 2 & 0 & 0 & 0 & 1.67 & 0.160 & 0.116 \\ 6 / 11 & 50 & 16.0 & 4 & 0 & 0 & 0 & 0 & - & 0.080 & 0.116 \\ 6 / 15 & 32 & 19.0 & 4 & 0 & 0 & 0 & 0 & - & 0.125 & 0.116 \\ 6 / 18 & 39 & 17.5 & 4 & 0 & 0 & 0 & 0 & - & 0.100 & 0.116 \\ & & & & & & & & & & \\ & & & & & & & & & & \end{array}$

a Number released is adjusted by the expected survival of test fish.

b Pooled TE was based on results of $\mathrm{Chi}^{2}$ tests. Mean pooled TE was based on the mean of subpooled estimates 
Table 6. Continued.

\begin{tabular}{|c|c|c|c|c|c|c|c|c|c|c|}
\hline \multirow{2}{*}{$\begin{array}{l}\text { Release } \\
\text { date }\end{array}$} & \multirow{2}{*}{$\begin{array}{l}\text { Number }^{a} \\
\text { released }\end{array}$} & \multirow{2}{*}{$\begin{array}{c}\text { Release } \\
\text { temp } \\
\left({ }^{\circ} \mathrm{C}\right) \\
\end{array}$} & \multicolumn{5}{|c|}{$\begin{array}{l}\text { Number detected by } \\
\text { days after release }\end{array}$} & \multirow{2}{*}{$\begin{array}{c}\text { Mean } \\
\text { travel time } \\
{(\text { days })^{b}}^{\text {dat }}\end{array}$} & \multirow{2}{*}{$\begin{array}{c}\text { Trap } \\
\text { efficiency } \\
(\mathrm{TE})\end{array}$} & \multirow{2}{*}{$\begin{array}{l}\text { Pooled } \\
\text { TE }^{c}\end{array}$} \\
\hline & & & $1-5$ & 6-10 & $11-15$ & $16-20$ & $>20$ & & & \\
\hline \multicolumn{11}{|c|}{$\begin{array}{c}\text { Hatchery } \\
\text { Summer Steelhead }\end{array}$} \\
\hline $4 / 9$ & 142 & 10.0 & 45 & 2 & 0 & 2 & 3 & 4.12 & 0.366 & 0.299 \\
\hline $4 / 12$ & 148 & 8.8 & 33 & 0 & 0 & 1 & 0 & 0.89 & 0.229 & 0.299 \\
\hline $5 / 2$ & 101 & 11.0 & 29 & 2 & 0 & 0 & 0 & 1.15 & 0.307 & 0.299 \\
\hline $5 / 11$ & 29 & 18.0 & 0 & 0 & 0 & 0 & 0 & - & 0.000 & - \\
\hline $5 / 14$ & 31 & 16.0 & 8 & 0 & 0 & 0 & 0 & 1.60 & 0.258 & 0.162 \\
\hline $5 / 16$ & 23 & 16.5 & 8 & 0 & 0 & 0 & 0 & 0.69 & 0.348 & 0.162 \\
\hline $5 / 19$ & 40 & 17.0 & 6 & 0 & 0 & 0 & 0 & 1.01 & 0.150 & 0.162 \\
\hline $5 / 22$ & 25 & 19.0 & 2 & 0 & 0 & 0 & 0 & 0.50 & 0.077 & - \\
\hline $5 / 26$ & 40 & 21.0 & 6 & 0 & 1 & 0 & 0 & 1.65 & 0.152 & 0.162 \\
\hline $5 / 29$ & 34 & 18.0 & 4 & 1 & 0 & 1 & 0 & 2.51 & 0.176 & 0.162 \\
\hline
\end{tabular}

Unmarked

Coho Salmon

$\begin{array}{lcccccccccc}3 / 22 & 100 & 11.1 & 6 & 0 & 0 & 0 & 4 & 9.89 & 0.100 & 0.121 \\ 3 / 27 & 100 & 10.0 & 4 & 0 & 0 & 2 & 4 & 16.25 & 0.100 & 0.121 \\ 4 / 4 & 102 & 10.0 & 10 & 0 & 0 & 0 & 3 & 6.07 & 0.127 & 0.121 \\ 4 / 9 & 94 & 10.0 & 8 & 0 & 0 & 4 & 3 & 12.77 & 0.159 & 0.121 \\ 4 / 17 & 90 & 15.0 & 19 & 2 & 1 & 2 & 1 & 4.18 & 0.277 & 0.303 \\ 4 / 24 & 70 & 15.0 & 30 & 1 & 1 & 0 & 0 & 1.88 & 0.457 & 0.303 \\ 5 / 5 & 75 & 15.0 & 19 & 0 & 0 & 0 & 0 & 1.49 & 0.253 & 0.303 \\ 5 / 13 & 50 & 17.0 & 19 & 0 & 0 & 0 & 0 & 0.66 & 0.380 & 0.303 \\ 5 / 22 & 75 & 19.0 & 14 & 0 & 0 & 0 & 0 & 0.16 & 0.186 & 0.303\end{array}$

Mean pooled $T E=0.222(S D=0.090)$

\section{Natural}

Chinook Salmon

$\begin{array}{lcccccccccc}6 / 6 & 49 & 17.0 & 7 & 0 & 0 & 0 & 0 & 0.21 & 0.143 & 0.063 \\ 6 / 7 & 48 & 18.0 & 1 & 0 & 0 & 0 & 0 & 0.28 & 0.020 & - \\ 6 / 12 & 47 & 15.0 & 5 & 0 & 0 & 0 & 0 & 0.91 & 0.104 & 0.063 \\ 6 / 15 & 23 & 19.0 & 1 & 0 & 0 & 0 & 0 & - & 0.043 & - \\ 6 / 18 & 50 & 17.5 & 0 & 0 & 0 & 0 & 0 & - & 0.000 & - \\ 6 / 26 & 56 & 17.0 & 4 & 0 & 0 & 0 & 0 & - & 0.071 & 0.063 \\ 6 / 30 & 71 & 19.0 & 4 & 0 & 0 & 0 & 0 & - & 0.055 & 0.063 \\ & & & & & & & & & & \end{array}$


Table 6. Continued.

\begin{tabular}{|c|c|c|c|c|c|c|c|c|c|c|}
\hline $\begin{array}{l}\text { Release } \\
\text { date }\end{array}$ & $\begin{array}{l}\text { Number } \\
\text { released }\end{array}$ & $\begin{array}{c}\text { Release } \\
\text { temp } \\
\left({ }^{\circ} \mathrm{C}\right)\end{array}$ & $1-5$ & $\begin{array}{r}\mathrm{Nu} \\
\mathrm{d} \\
6-10 \\
\end{array}$ & $\begin{array}{l}\text { ber det } \\
\text { s after } \\
11-15\end{array}$ & $\begin{array}{l}\text { ted by } \\
\text { lease } \\
16-20\end{array}$ & $>20$ & $\begin{array}{c}\text { Mean } \\
\text { travel time } \\
\text { (days) }\end{array}$ & $\begin{array}{c}\text { Trap } \\
\text { efficiency } \\
\text { (TE) }\end{array}$ & $\begin{array}{c}\text { Pooled } \\
\text { TE }\end{array}$ \\
\hline \multicolumn{11}{|c|}{$\begin{array}{c}\text { Natural } \\
\text { Summer Steelhead }\end{array}$} \\
\hline $5 / 2$ & 73 & 11.0 & 21 & 0 & 0 & 0 & 0 & 0.50 & 0.288 & 0.287 \\
\hline $5 / 11$ & 6 & 18.0 & 1 & 0 & 0 & 0 & 0 & 0.59 & 0.166 & - \\
\hline $5 / 14$ & 8 & 16.0 & 2 & 0 & 0 & 0 & 0 & 0.24 & 0.250 & - \\
\hline $5 / 16$ & 14 & 16.5 & 4 & 1 & 0 & 0 & 0 & 2.27 & 0.357 & 0.287 \\
\hline $5 / 19$ & 40 & 17.0 & 22 & 0 & 0 & 0 & 0 & 0.32 & 0.550 & 0.550 \\
\hline $5 / 22$ & 44 & 19.0 & 10 & 0 & 0 & 0 & 0 & 0.22 & 0.227 & 0.177 \\
\hline $5 / 26$ & 37 & 21.0 & 10 & 0 & 0 & 0 & 0 & 1.04 & 0.244 & 0.177 \\
\hline $5 / 29$ & 45 & 18.0 & 3 & 0 & 0 & 0 & 0 & 0.60 & 0.066 & - \\
\hline \multicolumn{11}{|c|}{ Mean pooled $T E=0.296(S D=0.136)$} \\
\hline
\end{tabular}


Table 7. Migration parameters of PIT-tagged hatchery, reach survival, and natural salmonids detected at West Extension Canal, RM 3.7, Umatilla River, March - September 2001

\begin{tabular}{|c|c|c|c|c|c|c|c|c|c|}
\hline \multirow{3}{*}{$\begin{array}{l}\text { Hatchery, } \\
\text { rearing } \\
\text { strategy }^{a}\end{array}$} & \multirow{2}{*}{\multicolumn{2}{|c|}{ Release $^{b}$}} & \multicolumn{6}{|c|}{ Detection at lower river } & \multirow{3}{*}{$\begin{array}{c}\text { Med. } \\
\text { travel } \\
\text { speed } \\
(\mathrm{mi} / \mathrm{d})^{c}\end{array}$} \\
\hline & & & \multirow[b]{2}{*}{$\mathrm{N}$} & \multirow{2}{*}{$\begin{array}{l}\text { First } \\
\text { (date) }\end{array}$} & \multirow{2}{*}{$\begin{array}{l}\text { Med. }^{c} \\
\text { (date) }\end{array}$} & \multirow{2}{*}{$\begin{array}{c}\text { Last } \\
\text { (date) }\end{array}$} & \multirow{2}{*}{$\begin{array}{c}\text { Peak } \\
\text { (date) }^{d}\end{array}$} & \multirow{2}{*}{$\begin{array}{c}\text { Duration } \\
\text { (days) }^{e}\end{array}$} & \\
\hline & Date & RM & & & & & & & \\
\hline \multicolumn{10}{|c|}{ Hatchery } \\
\hline \multicolumn{10}{|c|}{ Spring Chinook Salmon } \\
\hline \multicolumn{10}{|c|}{ Umatilla Fish Hatchery } \\
\hline Oregon $^{f}$ & $3 / 9$ & 80 & 50 & $3 / 8$ & $3 / 12$ & $5 / 2$ & $3 / 11$ & 55 & 25.4 \\
\hline Oregon & $3 / 9$ & 80 & 54 & $3 / 9$ & $3 / 11$ & $4 / 23$ & $3 / 11$ & 46 & 38.2 \\
\hline Michigan & $3 / 9$ & 80 & 78 & $3 / 8$ & $3 / 11$ & $4 / 28$ & $3 / 11$ & 51 & 38.2 \\
\hline \multicolumn{10}{|c|}{ Little White Salmon Hatchery } \\
\hline Standard & $3 / 16$ & 80 & 1 & $4 / 18$ & - & $4 / 18$ & - & - & 2.3 \\
\hline Standard & $4 / 17$ & 80 & 17 & $4 / 14$ & $4 / 27$ & $5 / 12$ & - & 29 & 7.6 \\
\hline \multicolumn{10}{|c|}{ Carson Fish Hatchery } \\
\hline Standard & $4 / 17$ & 80 & 11 & $4 / 19$ & $4 / 28$ & $5 / 8$ & - & 20 & 6.9 \\
\hline \multicolumn{10}{|c|}{ Fall Chinook Salmon } \\
\hline \multicolumn{10}{|c|}{ Bonneville Fish Hatchery } \\
\hline Standard & $3 / 16$ & 73.5 & 15 & $3 / 24$ & $4 / 13$ & $4 / 28$ & - & 36 & 2.5 \\
\hline Standard & $4 / 19$ & 73.5 & 61 & $4 / 19$ & $4 / 27$ & $5 / 11$ & $4 / 26-27$ & 23 & 8.7 \\
\hline \multicolumn{10}{|c|}{ Subyearling Fall Chinook Salmon } \\
\hline \multicolumn{10}{|c|}{ Umatilla Fish Hatchery } \\
\hline Acclimated & $5 / 24$ & 73.5 & 114 & $5 / 24$ & $5 / 27$ & $6 / 6$ & $5 / 27$ & 14 & 23.3 \\
\hline Acclimated & $5 / 24$ & 73.5 & 124 & $5 / 24$ & $5 / 27$ & $6 / 9$ & $5 / 27$ & 17 & 23.3 \\
\hline Direct stream & $5 / 24$ & 48 & 99 & $5 / 24$ & $5 / 27$ & $6 / 6$ & $5 / 27$ & 14 & 14.8 \\
\hline Direct stream & $5 / 25$ & 48 & 106 & $5 / 24$ & $5 / 27$ & $6 / 22$ & $5 / 27$ & 30 & 22.2 \\
\hline $\begin{array}{cc}a & \text { Oregon }=\text { reared } \\
& \text { Oregon raceway } \\
b & \text { Forced release d } \\
c & \text { Med. = median t } \\
d & \text { Peak date was nc } \\
e & \text { Duration = first c } \\
f & \text { Over wintered at }\end{array}$ & $\begin{array}{l}\text { n standa } \\
\text {, Acclin } \\
\text { es. } \\
\text { vel spee } \\
\text { reportec } \\
\text { y of det }\end{array}$ & $\begin{array}{l}\text { racew } \\
\text { ted = a } \\
\text { calcul } \\
\text { if less } \mathrm{t} \\
\text { ction to }\end{array}$ & $\begin{array}{l}\text { ys, Mic } \\
\text { climate } \\
\text { ed fron } \\
\text { an } 4 \text { fis } \\
\text { ast day }\end{array}$ & $\begin{array}{l}\text { gan }=r e \\
\text { at releas } \\
\text { oint of } \\
\text { were de } \\
\text { f detecti } \\
\text { (RM } 80\end{array}$ & $\begin{array}{l}\text { ared in st } \\
\text { site, anc } \\
\text { elease to } \\
\text { ected on }\end{array}$ & $\begin{array}{l}\text { Direct St } \\
\text { Dest Ext } \\
\text { ne day. }\end{array}$ & $\begin{array}{l}\text { ed raceway } \\
\mathrm{m}=\text { release } \\
\text { on Canal }(\mathrm{R}\end{array}$ & $\begin{array}{l}\text { Standard =eq } \\
\text { irectly into ri } \\
3.7)\end{array}$ & $\begin{array}{l}\text { ivalent to } \\
\text { rer. }\end{array}$ \\
\hline
\end{tabular}


Table 7. Continued.

\begin{tabular}{|c|c|c|c|c|c|c|c|c|c|}
\hline \multirow{2}{*}{$\begin{array}{l}\text { Hatchery, } \\
\text { rearing strategy }\end{array}$} & & & \multicolumn{6}{|c|}{ Detection at lower river } & \multirow{2}{*}{$\begin{array}{l}\text { Med. } \\
\text { travel } \\
\text { speed } \\
(\mathrm{mi} / \mathrm{d})\end{array}$} \\
\hline & \multicolumn{2}{|c|}{ Release $^{b}$} & $\mathrm{~N}$ & $\begin{array}{l}\text { First } \\
\text { (date) }\end{array}$ & $\begin{array}{l}\text { Med. }^{c} \\
\text { (date) }\end{array}$ & $\begin{array}{c}\text { Last } \\
\text { (date) }\end{array}$ & $\begin{array}{l}\text { Peak } \\
\text { (date) }^{d}\end{array}$ & $\begin{array}{l}\text { Duration } \\
\text { (days) }^{e}\end{array}$ & \\
\hline \multicolumn{10}{|c|}{ Coho Salmon } \\
\hline \multicolumn{10}{|c|}{ Cascade Hatchery } \\
\hline Standard & $3 / 15$ & 56 & 16 & $3 / 23$ & $5 / 5$ & $5 / 23$ & - & 62 & 1.0 \\
\hline Standard & $4 / 24$ & 56 & 80 & $4 / 26$ & $5 / 9$ & $5 / 24$ & $5 / 8$ & 31 & 2.5 \\
\hline \multicolumn{10}{|c|}{ Herman Creek Hatchery } \\
\hline Standard & $3 / 15$ & 56 & 7 & $3 / 18$ & $5 / 2$ & $5 / 23$ & - & 67 & 1.1 \\
\hline \multicolumn{10}{|c|}{ Summer Steelhead } \\
\hline \multicolumn{10}{|c|}{ Umatilla Fish Hatchery } \\
\hline Large grade & $4 / 4$ & 64.5 & 38 & $4 / 5$ & $4 / 30$ & $5 / 27$ & $5 / 26$ & 26 & 2.9 \\
\hline Large grade & $4 / 6$ & 79 & 32 & $4 / 7$ & $5 / 24$ & $6 / 11$ & $5 / 27$ & 18 & 1.6 \\
\hline Small grade & $4 / 26$ & 64.5 & 51 & $4 / 27$ & $5 / 18$ & $6 / 9$ & $5 / 27$ & 44 & 3.6 \\
\hline Small grade & $4 / 4$ & 64.5 & 53 & $4 / 7$ & $5 / 18$ & $6 / 4$ & $5 / 27$ & 59 & 1.7 \\
\hline Small grade & $4 / 6$ & 79 & 24 & $4 / 8$ & $5 / 23$ & $6 / 1$ & $5 / 27$ & 55 & 1.7 \\
\hline \multicolumn{10}{|c|}{$\begin{array}{l}\text { Reach Survival } \\
\text { Summer Steelhead }\end{array}$} \\
\hline \multicolumn{10}{|c|}{ Umatilla Fish Hatchery } \\
\hline Large grade & $4 / 3$ & 9 & 94 & $4 / 3$ & $4 / 4$ & $5 / 20$ & $4 / 4$ & 48 & 13.9 \\
\hline Large grade & $4 / 4$ & 9 & 80 & $4 / 4$ & $4 / 5$ & $5 / 13$ & $4 / 5$ & 40 & 9.5 \\
\hline Large grade & $4 / 5$ & 9 & 62 & $4 / 5$ & $4 / 6$ & $5 / 22$ & $4 / 6$ & 48 & 12.3 \\
\hline combined & & & 236 & & $4 / 5$ & & $4 / 4$ & 50 & 11.7 \\
\hline Large grade & $4 / 3$ & 27 & 54 & $4 / 4$ & $4 / 5$ & $5 / 23$ & $4 / 5$ & 50 & 14.9 \\
\hline Large grade & $4 / 4$ & 27 & 40 & $4 / 5$ & $4 / 6$ & $5 / 19$ & $4 / 6$ & 45 & 10.9 \\
\hline Large grade & $4 / 5$ & 27 & 48 & $4 / 6$ & $4 / 8$ & $5 / 8$ & $4 / 6$ & 33 & 7.5 \\
\hline combined & & & 142 & & $4 / 6$ & & $4 / 5$ & 50 & 11.7 \\
\hline Large grade & $4 / 3$ & 48 & 38 & $4 / 5$ & $4 / 14$ & $5 / 26$ & $4 / 5$ & 52 & 7.5 \\
\hline Large grade & $4 / 4$ & 48 & 50 & $4 / 5$ & $4 / 9$ & $6 / 7$ & $4 / 6$ & 64 & 8.3 \\
\hline Large grade & $4 / 5$ & 48 & 52 & $4 / 6$ & $4 / 17$ & $5 / 23$ & $4 / 7$ & 48 & 2.3 \\
\hline combined & & & 140 & & $4 / 12$ & & $4 / 5$ & 64 & 4.3 \\
\hline Large grade & $4 / 3$ & 64.5 & 33 & $4 / 5$ & $4 / 28$ & $5 / 28$ & $4 / 9$ & 54 & 2.4 \\
\hline Large grade & $4 / 4$ & 64.5 & 43 & $4 / 6$ & $4 / 28$ & $6 / 8$ & $4 / 7$ & 64 & 2.2 \\
\hline Large grade & $4 / 5$ & 64.5 & 42 & $4 / 7$ & $4 / 28$ & $5 / 28$ & $4 / 7$ & 52 & 2.6 \\
\hline combined & & & 118 & & $4 / 28$ & & $4 / 7$ & 65 & 2.5 \\
\hline
\end{tabular}


Table 7. Continued.

\begin{tabular}{|c|c|c|c|c|c|c|c|c|c|}
\hline \multirow{3}{*}{$\begin{array}{l}\text { Hatchery, } \\
\text { rearing strategy }\end{array}$} & & & \multicolumn{5}{|c|}{ Detection at lower river } & \multirow{3}{*}{$\begin{array}{l}\text { Duration } \\
{(\text { days })^{e}}\end{array}$} & \multirow{3}{*}{$\begin{array}{c}\text { Med. } \\
\text { travel } \\
\text { speed } \\
(\mathrm{mi} / \mathrm{d})\end{array}$} \\
\hline & \multicolumn{2}{|c|}{ Release $^{b}$} & \multirow[b]{2}{*}{$\mathrm{N}$} & \multirow{2}{*}{$\begin{array}{l}\text { First } \\
\text { (date) }\end{array}$} & \multirow{2}{*}{$\begin{array}{l}\text { Med. }{ }^{c} \\
\text { (date) }\end{array}$} & \multirow{2}{*}{$\begin{array}{l}\text { Last } \\
\text { (date) }\end{array}$} & \multirow{2}{*}{$\begin{array}{c}\text { Peak } \\
\text { (date) }^{d}\end{array}$} & & \\
\hline & Date & $\mathrm{RM}$ & & & & & & & \\
\hline \multicolumn{10}{|c|}{ Summer Steelhead } \\
\hline Large grade & $4 / 3$ & $79^{\mathrm{g}}$ & 26 & $4 / 6$ & $4 / 26$ & $5 / 30$ & - & 55 & 3.2 \\
\hline Large grade & $4 / 4$ & $79^{g}$ & 24 & $4 / 6$ & $4 / 25$ & $6 / 1$ & - & 57 & 2.7 \\
\hline \multirow{2}{*}{$\begin{array}{l}\text { Large grade } \\
\text { combined }\end{array}$} & $4 / 5$ & $79^{\mathrm{g}}$ & 33 & $4 / 7$ & $4 / 28$ & $5 / 28$ & - & 52 & 3.3 \\
\hline & & & 83 & & $4 / 27$ & & $4 / 7$ & 57 & 3.2 \\
\hline Small grade & $4 / 25$ & 9 & 118 & $4 / 25$ & $5 / 1$ & $5 / 24$ & $4 / 26$ & 30 & 0.9 \\
\hline Small grade & $4 / 26$ & 9 & 110 & $4 / 26$ & $4 / 28$ & $5 / 21$ & $4 / 27$ & 26 & 2.6 \\
\hline \multirow{2}{*}{$\begin{array}{l}\text { Small grade } \\
\text { combined }\end{array}$} & $4 / 27$ & 9 & 87 & $4 / 27$ & $4 / 29$ & $5 / 24$ & $4 / 28$ & 28 & 3.3 \\
\hline & & & 315 & & $4 / 29$ & & $4 / 27$ & 30 & 2.1 \\
\hline Small grade & $4 / 25$ & 27 & 76 & $4 / 26$ & $5 / 9$ & $5 / 24$ & $4 / 26-27$ & 29 & 1.7 \\
\hline Small grade & $4 / 26$ & 27 & 71 & $4 / 27$ & $5 / 7$ & $5 / 24$ & $4 / 28$ & 28 & 2.2 \\
\hline \multirow{2}{*}{$\begin{array}{l}\text { Small grade } \\
\text { combined }\end{array}$} & $4 / 27$ & 27 & 67 & $4 / 28$ & $5 / 10$ & $5 / 27$ & $4 / 28-29$ & 30 & 1.8 \\
\hline & & & 214 & & $5 / 9$ & & $4 / 28$ & 33 & 1.8 \\
\hline Small grade & $4 / 25$ & 48 & 70 & $4 / 26$ & $5 / 9$ & $6 / 3$ & $4 / 28$ & 39 & 3.7 \\
\hline Small grade & $4 / 26$ & 48 & 60 & $4 / 27$ & $5 / 16$ & $6 / 8$ & $5 / 28$ & 43 & 2.2 \\
\hline \multirow{2}{*}{$\begin{array}{l}\text { Small grade } \\
\text { combined }\end{array}$} & $4 / 27$ & 48 & 60 & $4 / 29$ & $5 / 14$ & $5 / 31$ & $4 / 29$ & 33 & 2.6 \\
\hline & & & 190 & & $5 / 14$ & & $4 / 28$ & 44 & 2.6 \\
\hline Small grade & $4 / 25$ & 64.5 & 41 & $4 / 28$ & $5 / 23$ & $6 / 9$ & $5 / 24$ & 43 & 2.2 \\
\hline Small grade & $4 / 26$ & 64.5 & 44 & $4 / 28$ & $5 / 24$ & $6 / 22$ & $5 / 26-28$ & 56 & 2.2 \\
\hline \multirow{2}{*}{$\begin{array}{l}\text { Small grade } \\
\text { combined }\end{array}$} & $4 / 27$ & 64.5 & 25 & $4 / 29$ & $5 / 15$ & $5 / 28$ & - & 30 & 3.3 \\
\hline & & & 110 & & $5 / 21$ & & $5 / 28$ & 56 & 2.3 \\
\hline \multicolumn{10}{|c|}{$\begin{array}{c}\text { Natural } \\
\text { Chinook Salmon }\end{array}$} \\
\hline \multirow[t]{2}{*}{ Umatilla River } & & & & & & & & & \\
\hline & $\begin{array}{l}10 / 23 \\
-5 / 3\end{array}$ & 80 & 74 & $3 / 11$ & $4 / 15$ & $5 / 26$ & $4 / 27$ & 77 & 2.2 \\
\hline \multicolumn{10}{|l|}{ Meacham Creek } \\
\hline \multirow{4}{*}{ Squaw Creek } & $11 / 14$ & 79 & 1 & $4 / 17$ & - & $4 / 17$ & - & - & 4.5 \\
\hline & $-3 / 31$ & & & & & & & & \\
\hline & & & & & & & & & \\
\hline & $\begin{array}{c}1 / 24- \\
2 / 2\end{array}$ & 77 & 2 & $3 / 31$ & $4 / 13$ & $4 / 27$ & - & 28 & 1.0 \\
\hline
\end{tabular}


Table 7. Continued.

\begin{tabular}{|c|c|c|c|c|c|c|c|c|c|}
\hline \multirow{3}{*}{$\begin{array}{l}\text { Hatchery, } \\
\text { rearing strategy }^{a}\end{array}$} & & & \multicolumn{5}{|c|}{ Detection at lower river } & \multirow{3}{*}{$\begin{array}{c}\text { Duration } \\
\left(_{\text {days })^{e}}\right.\end{array}$} & \multirow{3}{*}{$\begin{array}{c}\text { Med. } \\
\text { travel } \\
\text { speed } \\
(\mathrm{mi} / \mathrm{d})^{c}\end{array}$} \\
\hline & \multicolumn{2}{|c|}{ Release $^{b}$} & \multirow[b]{2}{*}{$\mathrm{N}$} & \multirow{2}{*}{$\begin{array}{l}\text { First } \\
\text { (date) }\end{array}$} & \multirow{2}{*}{$\begin{array}{l}\text { Med. }^{c} \\
\text { (date) }\end{array}$} & \multirow{2}{*}{$\begin{array}{l}\text { Last } \\
\text { (date) }\end{array}$} & \multirow{2}{*}{$\begin{array}{c}\text { Peak } \\
\left(^{(\text {date })^{d}}\right.\end{array}$} & & \\
\hline & Date & $\mathrm{RM}$ & & & & & & & \\
\hline \multirow{2}{*}{ Umatilla River } & \multicolumn{7}{|c|}{$\begin{array}{c}\text { Natural } \\
\text { Coho Salmon }\end{array}$} & & \\
\hline & $\begin{array}{l}12 / 8- \\
5 / 16\end{array}$ & 80 & 3 & $4 / 26$ & $5 / 10$ & $5 / 13$ & - & 18 & 0.57 \\
\hline \multicolumn{10}{|c|}{ ummer Steelhead } \\
\hline Umatilla River & $\begin{array}{c}10 / 23 \\
-5 / 3\end{array}$ & 80 & 77 & $3 / 12$ & $4 / 29$ & $6 / 1$ & $5 / 1$ & 82 & 2.4 \\
\hline Meacham Creek & $\begin{array}{l}11 / 14 \\
-3 / 31\end{array}$ & 79 & 50 & $3 / 16$ & $5 / 19$ & $6 / 1$ & $5 / 24,25,27$ & 78 & 1.2 \\
\hline Squaw Creek & $\begin{array}{c}1 / 24- \\
2 / 2\end{array}$ & 77 & 7 & $4 / 7$ & $5 / 4$ & $5 / 27$ & - & 51 & 0.8 \\
\hline East Birch Creek & $\begin{array}{l}1 / 12- \\
1 / 23\end{array}$ & 65 & 18 & $3 / 25$ & $4 / 28$ & $6 / 1$ & $5 / 26$ & 69 & 0.6 \\
\hline West Birch Cree & $\begin{array}{l}1 / 3- \\
1 / 5\end{array}$ & 65 & 13 & $4 / 9$ & $5 / 24$ & $5 / 28$ & $5 / 24$ & 50 & 0.4 \\
\hline
\end{tabular}


Table 8. Detection and travel speed of PIT-tagged hatchery summer steelhead released for reach survival tests and interrogated in the lower Umatilla River and mainstem Columbia River sites, March - July 2001.

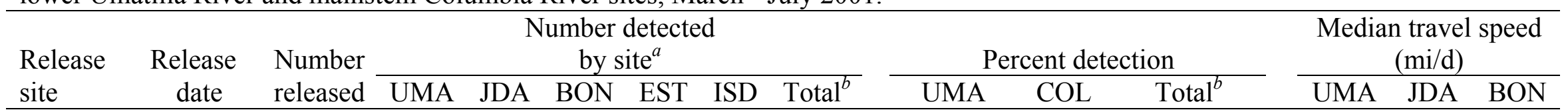

\begin{tabular}{|c|c|c|c|c|c|c|c|c|c|c|c|c|c|c|}
\hline \multicolumn{15}{|c|}{ Large Grade Summer Steelhead } \\
\hline \multirow[t]{2}{*}{ RM 9} & $4 / 3$ & 194 & 94 & 35 & 13 & 0 & 9 & 105 & 48.5 & 5.7 & 54.1 & 14.4 & 2.2 & 3.5 \\
\hline & $4 / 5$ & 197 & 63 & 20 & 9 & 0 & 13 & 80 & 32.0 & 8.6 & 40.6 & 12.8 & 2.3 & 3.3 \\
\hline \multicolumn{2}{|c|}{ Mean $(95 \%$ C.I). } & & & & & & & & $40.3( \pm 7.6)$ & & $48.7( \pm 6.6) A$ & & & \\
\hline RM 27 & $4 / 5$ & 253 & 49 & 26 & 15 & 0 & 8 & 71 & 19.4 & 8.7 & 28.1 & 7.5 & 3.1 & 4.6 \\
\hline \multicolumn{2}{|c|}{ Mean $(95 \%$ C.I). } & & & & & & & & $19.9( \pm 2.9)$ & & $28.3( \pm 0.5) B$ & & & \\
\hline \multirow[t]{3}{*}{ RM 48} & $4 / 3$ & 343 & 39 & 27 & 11 & 0 & 7 & 59 & 11.4 & 5.8 & 17.2 & 6.6 & 3.5 & 5.1 \\
\hline & $4 / 4$ & 360 & 51 & 23 & 10 & 0 & 10 & 77 & 14.2 & 7.2 & 21.4 & 8.3 & 3.2 & 4.9 \\
\hline & $4 / 5$ & 351 & 54 & 19 & 16 & 1 & 12 & 78 & 15.4 & 6.8 & 22.2 & 2.3 & 3.6 & 3.5 \\
\hline \multirow{2}{*}{\multicolumn{2}{|c|}{ Mean $(95 \%$ C.I). }} & 401 & 44 & 21 & 17 & 0 & 18 & 78 & 11.0 & 8.5 & 19.5 & 2.6 & 4.1 & 4.1 \\
\hline & & & & & & & & & $10.3( \pm 1.3)$ & & $17.5( \pm 1.7) C D$ & & & \\
\hline
\end{tabular}

${ }^{a} \mathrm{UMA}=$ Umatilla River, $\mathrm{COL}=$ Columbia River mainstem, JDA $=$ John Day Dam, BON $=$ Bonneville Dam, $\mathrm{EST}=\mathrm{Columbia}$ River estuary, ISD $=$ Columbia River islands with bird colonies.

$b$ Total does not include multiple detections among sites. Means with the same letter are not significantly different. 
Table 8. Continued.

\begin{tabular}{|c|c|c|c|c|c|c|c|c|c|c|c|c|c|c|}
\hline $\begin{array}{l}\text { Release } \\
\text { site }\end{array}$ & $\begin{array}{c}\text { Release } \\
\text { date }\end{array}$ & $\begin{array}{l}\text { Number } \\
\text { released }\end{array}$ & \multicolumn{6}{|c|}{$\begin{array}{c}\text { Number detected } \\
\text { by site }{ }^{a}\end{array}$} & \multicolumn{3}{|c|}{ Percent detection } & \multicolumn{3}{|c|}{$\begin{array}{l}\text { Median travel time } \\
\text { (days) }\end{array}$} \\
\hline \multirow[t]{2}{*}{ RM 79} & $4 / 3$ & 395 & 28 & 12 & 13 & 0 & 10 & 47 & 7.1 & 4.8 & 11.9 & 3.2 & 4.2 & 4.9 \\
\hline & $4 / 4$ & 392 & 24 & 19 & 18 & 1 & 9 & 46 & 6.1 & 5.6 & 11.7 & 2.7 & 4.0 & 4.2 \\
\hline \multicolumn{15}{|c|}{ Small Grade Summer Steelhead } \\
\hline \multirow[t]{3}{*}{ RM 9} & $4 / 25$ & 402 & 119 & 43 & 35 & 1 & 24 & 164 & 29.6 & 11.2 & 40.8 & 1.0 & 3.2 & 5.2 \\
\hline & $4 / 26$ & 403 & 111 & 43 & 25 & 4 & 29 & 162 & 27.5 & 12.7 & 40.2 & 2.7 & 3.4 & 5.4 \\
\hline & $4 / 27$ & 401 & 89 & 40 & 31 & 1 & 24 & 139 & 22.2 & 12.5 & 34.7 & 3.4 & 3.2 & 5.2 \\
\hline RM 27 & $4 / 27$ & 424 & 67 & 28 & 26 & 1 & 19 & 114 & 15.8 & 11.1 & 26.9 & 1.8 & 4.3 & 5.3 \\
\hline \multicolumn{2}{|c|}{ Mean $(95 \%$ C.I). } & & & & & & & & $16.9( \pm 1.2)$ & & $25.6( \pm 1.1) B$ & & & \\
\hline \multirow[t]{3}{*}{ RM 48} & $4 / 25$ & 495 & $74^{c}$ & 31 & 29 & 1 & 28 & 120 & 14.9 & 9.3 & 24.2 & 3.6 & 4.6 & 5.3 \\
\hline & $4 / 26$ & 494 & 64 & 19 & 19 & 1 & 22 & 100 & 13.0 & 7.3 & 20.2 & 2.2 & 4.9 & 5.2 \\
\hline & $4 / 27$ & 493 & $64^{c}$ & 22 & 24 & 3 & 18 & 98 & 13.0 & 6.9 & 19.9 & 2.6 & 4.9 & 5.3 \\
\hline \multicolumn{2}{|c|}{ Mean $(95 \%$ C.I). } & & & & & & & & $13.5( \pm 1.0)$ & & $21.3( \pm 2.2) B$ & & & \\
\hline \multirow[t]{3}{*}{ RM 64.5} & $4 / 25$ & 486 & 47 & 19 & 21 & 2 & 31 & 94 & 9.7 & 9.7 & 19.3 & 2.2 & 5.3 & 5.2 \\
\hline & $4 / 26$ & 492 & 51 & 15 & 18 & 0 & 20 & 81 & 10.4 & 6.1 & 16.5 & 2.2 & 5.3 & 5.5 \\
\hline & $4 / 27$ & 488 & $29^{c}$ & 13 & 13 & 2 & 16 & 57 & 5.9 & 5.7 & 11.7 & 3.3 & 5.7 & 5.5 \\
\hline \multicolumn{2}{|c|}{ Mean $(95 \%$ C.I). } & & & & & & & & $8.6( \pm 2.3)$ & & $15.8( \pm 3.7) \mathrm{C}$ & & & \\
\hline
\end{tabular}

${ }^{c}$ One fish from each 2001 release group was detected in 2002. 
Table 9. Summary of scale loss and mortality of hatchery and natural juvenile salmonids examined at RM 1.2 and RM 3.7, Umatilla River, October 2000 - September 2001.

\begin{tabular}{|c|c|c|c|c|c|c|c|c|}
\hline \multirow[b]{3}{*}{ Species $^{b}$} & \multicolumn{8}{|c|}{ Condition $^{a}$} \\
\hline & \multicolumn{2}{|c|}{ Good } & \multicolumn{2}{|c|}{ Partial } & \multicolumn{2}{|c|}{ Descaled } & \multicolumn{2}{|c|}{ Total Mortality $^{c}$} \\
\hline & Number & Percent & Number & Percent & Number & Percent & Number & Percent \\
\hline \multicolumn{9}{|c|}{ Hatchery } \\
\hline $\mathrm{CH}$ & 651 & 77.7 & 165 & 19.7 & 22 & 2.6 & 10 & 0.6 \\
\hline CHS & 1,481 & 81.1 & 310 & 17.0 & 36 & 2.0 & 22 & 0.9 \\
\hline $\mathrm{CHF}$ & 1,428 & 89.0 & 146 & 9.1 & 31 & 1.9 & 26 & 0.7 \\
\hline CHF0 & 1,311 & 79.5 & 286 & 17.3 & 52 & 3.1 & 51 & 1.2 \\
\hline $\mathrm{COH}$ & 378 & 69.7 & 138 & 25.5 & 26 & 4.8 & 1 & 0.1 \\
\hline STS & 965 & 56.1 & 617 & 35.9 & 137 & 8.0 & 20 & 1.0 \\
\hline Total & 6,214 & 76.0 & 1,662 & 20.3 & 304 & 3.7 & 130 & 0.9 \\
\hline \multicolumn{9}{|c|}{ Natural } \\
\hline $\mathrm{CH}$ & 1,375 & 95.3 & 54 & 3.7 & 13 & 0.9 & 70 & 4.0 \\
\hline $\mathrm{COH}$ & 175 & 91.1 & 12 & 6.3 & 5 & 2.6 & 1 & 0.5 \\
\hline STS & 633 & 78.1 & 151 & 18.7 & 26 & 3.2 & 15 & 1.8 \\
\hline Total & 2,183 & 89.3 & 217 & 8.9 & 44 & 1.8 & 86 & 3.0 \\
\hline \multicolumn{9}{|c|}{ Unmarked } \\
\hline $\mathrm{COH}$ & 3,089 & 73.5 & 930 & 22.1 & 186 & 4.4 & 20 & 0.1 \\
\hline Total & 3,089 & 73.5 & 930 & 22.1 & 186 & 4.4 & 20 & 0.1 \\
\hline
\end{tabular}

a Condition refers to the extent of scale loss on live fish captured and fish mortalities. Good $=$ scale loss $<3 \%$; Partial $=$ scale loss $>3 \%$ and $<20 \%$; Descaled $=$ scale loss $>20 \%$.

$b \quad \mathrm{CH}=$ chinook salmon of unknown race, $\mathrm{CHS}=$ spring chinook salmon, $\mathrm{CHF}=$ fall chinook salmon, $\mathrm{CHF} 0=$ subyearling fall chinook salmon, $\mathrm{COH}=$ coho salmon, $\mathrm{STS}=$ summer steelhead.

$c$ Total mortality includes both sampling and natural mortalities; percent mortality is calculated using total number of fish sampled, not just those examined. 
Table 10. Total number and percentage of bird marks, body injuries, and parasites observed on juvenile salmonids examined at RM 1.2 and RM 3.7, Umatilla River, October 2000 -

September 2001.

\begin{tabular}{|c|c|c|c|c|c|c|c|}
\hline \multirow[b]{3}{*}{ Species $^{b}$} & \multicolumn{7}{|c|}{ Condition $^{a}$} \\
\hline & \multicolumn{2}{|c|}{ Bird marks } & \multicolumn{2}{|c|}{ Injuries } & \multicolumn{2}{|c|}{ Parasites } & \multirow{2}{*}{$\begin{array}{c}\text { Total number } \\
\text { examined }\end{array}$} \\
\hline & Number & Percent $^{c}$ & Number & Percent & Number & Percent & \\
\hline \multicolumn{8}{|c|}{ Hatchery } \\
\hline $\mathrm{CH}$ & 48 & 5.7 & 41 & 4.9 & 9 & 1.1 & 838 \\
\hline CHS & 101 & 5.5 & 117 & 6.4 & 32 & 1.8 & 1,827 \\
\hline CHF & 59 & 3.7 & 70 & 4.4 & 6 & 0.4 & 1,605 \\
\hline CHF0 & 39 & 2.4 & 39 & 2.4 & 0 & 0.0 & 1,649 \\
\hline $\mathrm{COH}^{d}$ & 23 & 4.2 & 8 & 1.5 & 1 & 0.2 & 542 \\
\hline STS & 136 & 7.9 & 53 & 3.1 & 23 & 1.3 & 1,719 \\
\hline Total & 406 & 5.0 & 328 & 4.0 & 71 & 0.9 & 8,180 \\
\hline \multicolumn{8}{|c|}{ Natural } \\
\hline $\mathrm{CH}^{e}$ & 10 & 0.7 & 30 & 2.1 & 53 & 3.7 & 1,442 \\
\hline $\mathrm{COH}$ & 2 & 1.0 & 11 & 5.7 & 6 & 3.1 & 192 \\
\hline STS & 30 & 3.7 & 29 & 3.6 & 60 & 7.4 & 810 \\
\hline Total & 42 & 1.7 & 70 & 2.9 & 119 & 4.9 & 2,444 \\
\hline \multicolumn{8}{|c|}{ Unmarked } \\
\hline $\mathrm{COH}$ & 153 & 3.6 & 109 & 2.6 & 24 & 0.6 & 4,205 \\
\hline Total & 153 & 3.6 & 109 & 2.6 & 24 & 0.6 & 4,205 \\
\hline
\end{tabular}

a Condition refers to the presence of bird marks, body injuries, and external parasites. Body injuries include damaged eyes, operculum, head, body, and fins and presence of fungus. Parasites include leeches and nematode metacercaria. Some fish with bird marks and parasites also had body injuries.

$b \quad \mathrm{CH}=$ spring and fall chinook salmon, $\mathrm{CHF} 0=$ subyearling fall chinook salmon, $\mathrm{COH}=$ coho salmon, $\mathrm{STS}=$ summer steelhead.

$c$ Percent is based on all fish examined.

$d$ Only coho with an adipose fin clip were designated as hatchery origin.

$e \quad \mathrm{CH}=$ natural chinook salmon includes yearling and subyearling age groups. 
Table 11. Correlation of mean daily river flow $\left(\mathrm{ft}^{3} / \mathrm{s}\right)$ and capture of juvenile Pacific lamprey at RM 1.2 and 3.7, Umatilla River, December 2000 - May 2001.

\begin{tabular}{|c|c|c|c|}
\hline Life stage & $N^{a}$ & $r^{b}$ & $P .05^{c}$ \\
\hline \multicolumn{4}{|c|}{ RM 1.2} \\
\hline Larvae & 14 & 0.642 & 0.013 \\
\hline Macrophothalmia & 18 & 0.643 & $<0.001$ \\
\hline \multicolumn{4}{|c|}{ RM 3.7} \\
\hline Larvae & 11 & 0.272 & 0.419 \\
\hline Macrophothalmia & 8 & 0.032 & 0.940 \\
\hline
\end{tabular}

${ }^{a} \mathrm{~N}=$ number of observations.

${ }^{b} \mathrm{r}=$ correlation coefficient.

$c$ Probability (t-test) that the correlation coefficient is no different from zero; significant $\mathrm{P} \leq 0.05$.

Table 12. Mark - recapture data, abundance estimates, and confidence intervals of emigrating juvenile lamprey, Umatilla River, October 2000 - September 2001.

\begin{tabular}{lcccc}
\hline Item & \multicolumn{2}{c}{ Macrophothalmia } & \multicolumn{2}{c}{ Larvae } \\
\hline Year & 2000 & 2001 & 2000 & 2001 \\
& & & & \\
Total number of marked lamprey & 129 & 343 & -- & 411 \\
Total number of recaptured lamprey & 1 & 22 & -- & 3 \\
Trapping efficiency & 0.008 & 0.064 & -- & 0.007 \\
Abundance estimate & 17,157 & 28,485 & & 97,408 \\
$95 \% \mathrm{CI}^{a}$ & $( \pm 14,902)$ & $( \pm 13,595)$ & -- & $( \pm 159,461)$ \\
\hline
\end{tabular}

${ }^{a} \mathrm{CI}=$ confidence interval 
Table 13. Detection, abundance, and survival of PIT-tagged production fish released into the upper_Umatilla River and detected in the lower river, March - June 2001.

\begin{tabular}{|c|c|c|c|c|c|c|c|c|}
\hline Hatchery $^{a}$ & Raceway & $\begin{array}{l}\text { Volitional } \\
\text { release } \\
\text { date }\end{array}$ & $\begin{array}{l}\text { Release } \\
\text { site }\end{array}$ & $\begin{array}{l}\text { Release } \\
\text { number }\end{array}$ & $\begin{array}{r}\text { Detection } \\
\text { at RM } 3.7 \\
\end{array}$ & $\begin{array}{c}\text { Percent } \\
\text { detection }\end{array}$ & $\begin{array}{l}\text { Abun- } \\
\text { dance }\end{array}$ & $\begin{array}{l}\text { Percent } \\
\text { survival } \\
(95 \% \text { C.I. })\end{array}$ \\
\hline \multicolumn{9}{|c|}{ Spring Chinook Salmon } \\
\hline UFH & $\mathrm{O} 4 \mathrm{~A}$ & $3 / 3 / 01$ & RM 80 & 294 & 25 & 8.5 & 356 & $121.1( \pm 73.4)$ \\
\hline UFH & O4B & $3 / 3 / 01$ & RM 80 & 299 & 29 & 9.7 & 442 & $147.8( \pm 17.1)$ \\
\hline UFH & $\mathrm{O} 5 \mathrm{~A}$ & $3 / 3 / 01$ & RM 80 & 298 & 22 & 7.4 & 295 & $99.0( \pm 59.4)$ \\
\hline UFH & O5B & $3 / 3 / 01$ & RM 80 & 295 & 31 & 10.5 & 382 & $129.5( \pm 75.1)$ \\
\hline UFH & $\mathrm{M} \mathrm{A}^{\mathrm{b}}$ & $3 / 3 / 01$ & RM 80 & 280 & 29 & 10.4 & 406 & $145.0( \pm 84.2)$ \\
\hline UFH & $\mathrm{M}^{1 \mathrm{~B}^{\mathrm{b}}}$ & $3 / 3 / 01$ & RM 80 & 290 & 24 & 8.3 & 382 & $131.7( \pm 78.0)$ \\
\hline UFH & $\mathrm{M} 1 \mathrm{C}$ & $3 / 3 / 01$ & RM 80 & 293 & 26 & 8.9 & 412 & $140.6( \pm 80.6)$ \\
\hline LWSH & $39-43$ & $3 / 10 / 01$ & RM 80 & 289 & 1 & 0.3 & 4 & $1.4( \pm 2.3)$ \\
\hline LWSH & $34-38$ & $4 / 11 / 01$ & RM 80 & 286 & 17 & 5.9 & 41 & $14.3( \pm 7.1)$ \\
\hline $\mathrm{CFH}$ & $37-40$ & $4 / 11 / 01$ & RM 80 & 288 & 11 & 3.8 & 26 & $9.0( \pm 4.7)$ \\
\hline $\begin{array}{l}\text { Overall } \\
95 \% \text { C.I. }\end{array}$ & & & & & & & $\begin{array}{r}2746 \\
(75 .\end{array}$ & $\begin{array}{c}94.3 \\
-112.9 \%)\end{array}$ \\
\hline \multicolumn{9}{|c|}{ Yearling Fall Chinook Salmon } \\
\hline $\mathrm{BFH}$ & A7-11 & $3 / 10 / 01$ & RM 73.5 & 271 & 14 & 5.2 & 81 & $26.9( \pm 14.5)$ \\
\hline $\mathrm{BFH}$ & A2-6 & $4 / 13 / 01$ & RM 73.5 & 295 & 61 & 20.7 & 222 & $75.3( \pm 21.1)$ \\
\hline $\begin{array}{l}\text { Overall } \\
95 \% \text { C.I. }\end{array}$ & & & & & & & $\begin{array}{l}303 \\
138.5\end{array}$ & $\begin{array}{r}53.5 \\
-68.1 \%)\end{array}$ \\
\hline \multicolumn{9}{|c|}{ Subvearling Fall Chinook Salmon } \\
\hline UFH & $\mathrm{O} 1 \mathrm{~A}$ & $5 / 21 / 01$ & RM 73.5 & 290 & 114 & 39.3 & 334 & $115.2( \pm 23.8)$ \\
\hline UFH & O1B & $5 / 21 / 01$ & RM 73.5 & 292 & 124 & 42.5 & 369 & $126.4( \pm 24.9)$ \\
\hline UFH & $\mathrm{O} 2 \mathrm{~A}$ & $5 / 25 / 01$ & $\mathrm{RM} 48.5$ & 290 & 106 & 36.6 & 315 & $108.6( \pm 23.8)$ \\
\hline UFH & $\mathrm{O} 2 \mathrm{~B}$ & $5 / 24 / 01$ & $\mathrm{RM} 48.5$ & 300 & 99 & 33.0 & 293 & $97.7( \pm 21.0)$ \\
\hline \multicolumn{5}{|l|}{$\begin{array}{l}\text { Overall } \\
95 \% \text { C.I. }\end{array}$} & & & \multicolumn{2}{|c|}{$\begin{array}{cc}1311 & 112.0 \\
(100.3 & -123.7 \%)\end{array}$} \\
\hline \multicolumn{9}{|c|}{$\begin{array}{l}\text { UFH = Umatilla Fish Hatchery, LWSH = Little White Salmon Hatchery, CFH }=\text { Carson National Fish Hatchery, } \\
\text { BFH = Bonneville Fish Hatchery, CFH = Cascade Fish Hatchery; HCFH = Herman Creek Fish Hatchery. } \\
\text { Michigan super-oxygenated fish. }\end{array}$} \\
\hline
\end{tabular}




\begin{tabular}{|c|c|c|c|c|c|c|c|c|}
\hline Hatchery $^{a}$ & Raceway & $\begin{array}{c}\text { Volitional } \\
\text { release } \\
\text { date } \\
\end{array}$ & $\begin{array}{c}\text { Release } \\
\text { site }\end{array}$ & $\begin{array}{l}\text { Release } \\
\text { number }\end{array}$ & $\begin{array}{l}\text { Detection } \\
\text { at RM } 3.7\end{array}$ & $\begin{array}{c}\text { Percent } \\
\text { detection }\end{array}$ & $\begin{array}{l}\text { Abun- } \\
\text { dance }^{f}\end{array}$ & $\begin{array}{l}\text { Percent } \\
\text { survival } \\
\text { (95\% C.I.) }\end{array}$ \\
\hline \multicolumn{9}{|c|}{ Summer Steelhead } \\
\hline UFH & $\mathrm{M}_{8} \mathrm{~B}^{\mathrm{d}}$ & $3 / 31 / 01$ & RM 64.5 & 296 & 32 & 10.8 & 167 & $56.4_{( \pm 23.6)}$ \\
\hline UFH & $M 8 C^{d}$ & $3 / 28 / 01$ & $\mathrm{RM} 79^{\mathrm{c}}$ & 282 & 38 & 13.5 & 167 & $59.2_{( \pm 20.6)}$ \\
\hline UFH & $M 8 A^{e}$ & $4 / 23 / 01$ & RM 64.5 & 581 & 51 & 8.8 & 278 & $47.8( \pm 17.6)$ \\
\hline UFH & $\mathrm{MAC}^{\mathrm{e}}$ & $3 / 5 / 01$ & RM 64.5 & 586 & 53 & 9.0 & 267 & $45.6( \pm 8.1)$ \\
\hline UFH & $\mathrm{MAB}^{\mathrm{e}}$ & $3 / 5 / 01$ & $\mathrm{RM} 79^{\mathrm{c}}$ & 577 & 24 & 4.2 & 124 & $21.5( \pm 6.7)$ \\
\hline $\begin{array}{l}\text { Overall } \\
95 \% \text { C.I. }\end{array}$ & & & & & & & $\begin{array}{l}1003 \\
\quad(35.4\end{array}$ & $\begin{array}{r}43.2 \\
-51 \%)\end{array}$ \\
\hline \multicolumn{9}{|c|}{ Coho Salmon } \\
\hline $\mathrm{CFH}$ & PE1 & $3 / 15 / 01$ & RM 56 & 291 & 16 & 5.5 & 68 & $23.4( \pm 12.7)$ \\
\hline $\mathrm{CFH}$ & PE2 & $4 / 18 / 01$ & RM 56 & 294 & 42 & 14.3 & 139 & $47.3( \pm 14.2)$ \\
\hline $\mathrm{CFH}$ & PE2 & $4 / 18 / 01$ & RM 56 & 297 & 38 & 12.8 & 126 & $42.4( \pm 13.1)$ \\
\hline $\mathrm{HCFH}$ & PE3 & $3 / 15 / 01$ & RM 56 & 296 & 7 & 2.4 & 22 & $7.4( \pm 5.7)$ \\
\hline $\begin{array}{l}\text { Overall } \\
95 \% \text { C. I. }\end{array}$ & & & & & & & \multicolumn{2}{|c|}{$(24.2-36 \%)$} \\
\hline
\end{tabular}


Table 14. Detection, abundance, and survival of natural fish PIT-tagged in the upper Umatilla River and tributaries and detected in the lower river, March - June 2001.

\begin{tabular}{|c|c|c|c|c|c|}
\hline Release Site $^{a}$ & $\begin{array}{l}\text { Number } \\
\text { released }\end{array}$ & $\begin{array}{l}\text { Number } \\
\text { detected }\end{array}$ & $\begin{array}{l}\text { Percent } \\
\text { detection }\end{array}$ & Abundance $^{b}$ & $\begin{array}{l}\text { Percent } \\
\text { survival }\end{array}$ \\
\hline \multicolumn{6}{|c|}{ Spring Chinook Salmon } \\
\hline Umatilla River & 1,547 & 74 & 4.8 & 1,139 & $73.6( \pm 39.3)$ \\
\hline Meacham & 125 & 1 & 0.8 & 16 & $12.8( \pm 27.3)$ \\
\hline Squaw Creek & 6 & 2 & 33.3 & 32 & 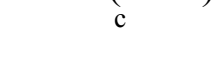 \\
\hline Total & 1,678 & 77 & 4.6 & 1,187 & $70.7( \pm 36.5)$ \\
\hline \multicolumn{6}{|c|}{ Coho Salmon } \\
\hline Umatilla River & 251 & 3 & 1.2 & 10 & $4.0( \pm 3.8)$ \\
\hline Total & 251 & 3 & 1.2 & 10 & $4.0( \pm 3.8)$ \\
\hline \multicolumn{6}{|c|}{ Summer Steelhead } \\
\hline Umatilla River & 944 & 76 & 8.1 & 301 & $31.9( \pm 10.7)$ \\
\hline Meacham & 989 & 50 & 5.1 & 223 & $22.6( \pm 9.2)$ \\
\hline Squaw Creek & 261 & 7 & 2.7 & 28 & $10.7( \pm 8.2)$ \\
\hline East Fork Birch Cr & 224 & 18 & 8.3 & 76 & $33.9( \pm 17.5)$ \\
\hline West Fork Birch Cr & 203 & 13 & 6.4 & 63 & $31.0( \pm 20.2)$ \\
\hline Total & 2,621 & 164 & 6.3 & 691 & $26.4( \pm 5.7)$ \\
\hline
\end{tabular}

${ }^{a}$ Umatilla River $=$ RM 80, Meacham $=$ RM 79, Squaw Creek $=$ RM 77, Birch Creek $=$ RM 48, East Fork Birch Creek $=$ RM 16 of Birch Creek., West Fork Birch Creek = RM 16 of Birch Creek.

${ }^{b}$ See Methods for abundance estimation method.

${ }^{c}$ Unable to estimate survival due to low sample size. 
Table 16. Detection, abundance, and survival of PIT-tagged summer steelhead released for reach-specific survival tests and interrogated at West Extension Canal (RM 3.7), March - July 2001.

\begin{tabular}{|c|c|c|c|c|c|c|}
\hline $\begin{array}{l}\text { Release } \\
\text { dates }\end{array}$ & $\begin{array}{c}\text { Release } \\
\text { sites }\end{array}$ & $\begin{array}{l}\text { Release } \\
\text { number }\end{array}$ & $\begin{array}{c}\text { Number } \\
\text { detected }^{a}\end{array}$ & $\begin{array}{c}\text { Mean \% } \\
\text { Detection } \\
\text { (95\% C.I.) }\end{array}$ & Abundance $^{b}$ & $\begin{array}{c}\text { Mean } \\
\text { Survival } \\
(95 \% \text { C.I. })^{c}\end{array}$ \\
\hline \multicolumn{7}{|c|}{ Large Grade Steelhead } \\
\hline $4 / 3-4 / 5$ & RM 9 & 589 & 236 & $40.1( \pm 7.8)$ & 800 & $136.0( \pm 26.7) \mathrm{A}$ \\
\hline $4 / 3-4 / 5$ & RM 27 & 721 & 142 & $19.7( \pm 3.0)$ & 499 & $69.1( \pm 11.3)$ в \\
\hline $4 / 3-4 / 5$ & RM 48 & 1,054 & 140 & $13.3( \pm 1.8)$ & 517 & $49.0( \pm 8.2) \mathrm{C}$ \\
\hline $4 / 3-4 / 5$ & RM 64.5 & 1,184 & 118 & $10.0( \pm 1.3)$ & 499 & $42.2( \pm 6.1) \mathrm{CD}$ \\
\hline $4 / 3-4 / 5$ & $\mathrm{RM} 79^{d}$ & 1,171 & 83 & $7.1( \pm 1.2)$ & 354 & $30.3( \pm 5.5) \mathrm{D}$ \\
\hline
\end{tabular}

Small Grade Steelhead

\begin{tabular}{lcccccc}
$4 / 25-4 / 27$ & RM 9 & 1,206 & 315 & $26.1( \pm 3.7)$ & 1,352 & $112.1( \pm 16.5) \mathrm{A}$ \\
$4 / 25-4 / 27$ & RM 27 & 1,282 & 214 & $16.7( \pm 1.0)$ & 1,003 & $78.3( \pm 5.1) \mathrm{B}$ \\
$4 / 25-4 / 27$ & RM 48 & 1,482 & $190^{e}$ & $13.5( \pm 0.9)$ & 994 & $67.1( \pm 0.7) \mathrm{B}$ \\
$4 / 25-4 / 27$ & RM 64.5 & 1,466 & $110^{e}$ & $8.6( \pm 2.0)$ & 625 & $42.6( \pm 11.1) \mathrm{C}$ \\
\hline
\end{tabular}

a Detections from the east bank ladder are not included.

$b$ See Methods for abundance estimation method.

$c$ Means with the same letter are not significantly different.

$d$ RM 2 of Meacham Creek at RM 79 of the Umatilla Rvier.

${ }^{e}$ Two fish from RM 48 and 1 fish from RM 64.5 were not included in the analysis because they were detected in 2002 . 
Table 17. Summary of PIT-tagged hatchery subyearling fall chinook salmon released for transportation evaluation studies (trap and haul operations), Umatilla River, June - August 2001.

\begin{tabular}{lccccc}
\hline $\begin{array}{l}\text { Release } \\
\text { group }\end{array}$ & $\begin{array}{c}\text { Release } \\
\text { date }\end{array}$ & $\begin{array}{c}\text { Release } \\
\text { temperature }\end{array}$ & $\begin{array}{c}\text { Release } \\
\text { number }\end{array}$ & $\begin{array}{c}\text { Number } \\
\text { detected }^{a}\end{array}$ & $\begin{array}{c}\text { Percent } \\
\text { detection }\end{array}$ \\
\hline WC1 & \multicolumn{7}{c}{ Control (Non-transported) } & & \\
WC2 & $6 / 25 / 01$ & 13.0 & 253 & 8 & 3.2 \\
WC3 & $6 / 27 / 01$ & 14.5 & 252 & 4 & 1.6 \\
WC4 & $6 / 29 / 01$ & 17.0 & 257 & 0 & 0.0 \\
WC5 & $7 / 1 / 01$ & 19.0 & 254 & 2 & 0.8 \\
& $7 / 2 / 01$ & 17.0 & 231 & 0 & 0.0 \\
& & & & & \\
WT1 & & Treatment (Transported) & & \\
WT2 & $7 / 9 / 01$ & & & & \\
WT3 & $7 / 11 / 01$ & 20.0 & 261 & 28 & 10.7 \\
WT4 & $7 / 13 / 01$ & 21.0 & 246 & 28 & 5.1 \\
\hline
\end{tabular}

a Number detected includes detections at mainstem Columbia River dams and mainstem island recoveries.

Table 18. Correlation of daily PIT tag detections with mean daily river flow $\left(\mathrm{ft}^{3} / \mathrm{s}\right)$ and water temperature $\left({ }^{\circ} \mathrm{C}\right)$ at RM 3.7, Umatilla River, March - June 2001.

\begin{tabular}{|c|c|c|c|c|c|c|}
\hline \multirow[b]{2}{*}{ Species $^{a}$} & \multicolumn{3}{|c|}{ Flow } & \multicolumn{3}{|c|}{ Temperature } \\
\hline & $N^{b}$ & $r^{c}$ & $P_{.05}{ }^{d}$ & $N^{b}$ & $r^{c}$ & $P .05{ }^{d}$ \\
\hline HCHS & 38 & -0.210 & 0.205 & 38 & -0.286 & 0.082 \\
\hline $\mathrm{HCHF}$ & 28 & 0.182 & 0.354 & 28 & 0.432 & 0.022 \\
\hline HCHF0 & 11 & -0.603 & 0.049 & 11 & 0.445 & 0.170 \\
\hline $\mathrm{HCOH}$ & 32 & -0.145 & 0.429 & 32 & 0.252 & 0.164 \\
\hline HSTS (large) & 36 & -0.281 & 0.096 & 36 & 0.357 & 0.032 \\
\hline HSTS (small) & 26 & -0.022 & 0.915 & 26 & 0.250 & 0.218 \\
\hline $\mathrm{NCH}$ & 44 & 0.235 & 0.125 & 44 & 0.147 & 0.341 \\
\hline $\mathrm{NCOH}$ & 3 & -- & -- & 3 & -- & -- \\
\hline NSTS & 59 & -0.270 & 0.039 & 59 & 0.499 & $<.001$ \\
\hline $\begin{array}{ll}a & \text { HCHS = hatch } \\
& \text { subyearling fall } \\
& \text { steelhead, HST } \\
& \text { unknown race, } \\
b & \mathrm{~N}=\text { number of } \\
c & \mathrm{r}=\text { correlation } \\
d & \text { Probability (t- }\end{array}$ & $\begin{array}{l}\text { g chi } \\
\text { x saln } \\
=\text { sn } \\
=\text { nat } \\
\text { tions } \\
\text { nt }\end{array}$ & $\begin{array}{l}\text { salmon, } \mathrm{H} \\
\mathrm{ICOH}=\mathrm{h} \\
\text { rade sumn } \\
\text { ho, and } \mathrm{N}\end{array}$ & $\begin{array}{l}\text { = hatch } \\
\text { ery coho, } \\
\text { natchery } \\
=\text { natura }\end{array}$ & $\begin{array}{l}\text { inook } \\
\text { ge-gra }\end{array}$ & $\begin{array}{l}\text { on, } \mathrm{HCHF} \\
\text { immer hat } \\
\text { ok salmor } \\
\mathrm{P}<0.05\end{array}$ & $\begin{array}{l}\text { hatchery } \\
\text { y }\end{array}$ \\
\hline
\end{tabular}


Table 19. Percentage of total natural chinook salmon and steelhead detections within given environmental categories. Number in parenthesis is the percentage of the total detection period within each environmental category. * represents significance $(P \leq 0.05)$.

\begin{tabular}{lll}
\hline Environmental Parameters & Chinook Salmon & Steelhead
\end{tabular}

Total River Flow (RM 37.6)

\begin{tabular}{|c|c|c|}
\hline $0-<250 \mathrm{ft}^{3} / \mathrm{s}$ & $0.0(0.0)$ & $0.0(0.0)$ \\
\hline $250-<500 \mathrm{ft}^{3} / \mathrm{s}$ & $2.6(9.1)$ & $37.9(15.9)$ \\
\hline $500-<750 \mathrm{ft}^{3} / \mathrm{s}$ & $7.8(19.5)$ & $10.8(18.3)$ \\
\hline $750-<1,000 \mathrm{ft}^{3} / \mathrm{s}$ & $3.9(9.1)$ & $3.6(7.3)$ \\
\hline$\geq 1,000 \mathrm{ft}^{3} / \mathrm{s}$ & $85.7(62.3)$ & $47.6(58.5)$ \\
\hline & $47.1 *$ & $24.3 *$ \\
\hline
\end{tabular}

Change in River Flow (RM 37.6)

$\geq-10 \%$

$20.8(23.4)$

$17.5(20.7)$

$>-1-<-10 \%$

$27.3(40.3)$

$38.5(39.0)$

Within $\pm 1 \%$

$3.9(5.2)$

$20.5(8.5)$

$>1-<10 \%$

$24.7(13.0)$

$\geq 10 \%$

$23.4(18.2)$

$13.3(14.6)$

$10.2(17.1)$

$13.6^{*}$

12.3

Water Temperature (RM 37.6)
$<10.0{ }^{\circ} \mathrm{C}$
$10.0-<12.2^{\circ} \mathrm{C}$
$12.2-<15.0^{\circ} \mathrm{C}$
$15.0-<17.2^{\circ} \mathrm{C}$
$17.2-20.0^{\circ} \mathrm{C}$
$>20.0^{\circ} \mathrm{C}$

$X^{2}=$
$61.0(55.8)$
$13.0(7.8)$
$20.8(20.8)$
$1.3(5.2)$
$3.9(5.2)$
$0.0(5.2)$

$X^{2}=$

$36.7(51.2)$

$5.4(7.3)$

$19.3(19.5)$

$6.0(6.1)$

$21.1(6.1)$

$11.5(9.8)$

$14.6^{*}$

$17.3 *$ 
Table 20. Correlations between travel speed (mi/d) and mean daily river flow $\left(\mathrm{ft}^{3} / \mathrm{s}\right)$ within various migration corridors of the Umatilla River.

\begin{tabular}{lcccc}
\hline Release Site & Group ${ }^{\mathrm{a}}$ & $N$ & $r$ & $P_{.05}{ }^{b}$ \\
\hline \multirow{2}{*}{ Bonifer (RM 79) } & Steelhead (large) & 83 & 0.327 & $<0.01$ \\
& Steelhead (small) & -- & -- & -- \\
Minthorn (RM 65) & Steelhead (large) & 118 & 0.312 & $<0.01$ \\
& Steelhead (small) & 110 & 0.807 & $<0.01$ \\
Rieth (RM 48) & & & \\
& Steelhead (large) & 140 & 0.278 & $<0.01$ \\
& Steelhead (small) & 190 & 0.661 & $<0.01$ \\
Echo (RM 27) & Steelhead (large) & 142 & 0.528 & $<0.01$ \\
& Steelhead (small) & 214 & 0.565 & $<0.01$ \\
Steelhead Park (RM 9) & Steelhead (large) & 236 & 0.431 & $<0.01$ \\
& Steelhead (small) & 315 & 0.380 & $<0.01$ \\
\hline
\end{tabular}

a Hatchery summer steelhead are released in both large-grade and small-grade groups determined by fish size

${ }^{b}$ Probability (t-test) that the correlation coefficient is no different from zero; significant $\mathrm{P} \leq 0.05$ 
Table 21. Correlation between daily canal diversion rate and daily trap efficiency estimates at RM 3.7, Umatilla River, March - July 2001.

\begin{tabular}{lccc}
\hline Species $^{a}$ & $N^{b}$ & $r^{c}$ & $P_{.05}{ }^{d}$ \\
\hline HCHS & 30 & 0.138 & 0.468 \\
HCHF & 49 & -0.201 & 0.167 \\
HCHF0 & 15 & -0.112 & 0.692 \\
HSTS & 35 & 0.021 & 0.904 \\
NCH & 6 & -0.389 & 0.446 \\
NSTS & 14 & 0.727 & 0.003 \\
UCOH & 30 & 0.473 & 0.008 \\
\hline
\end{tabular}

a $\mathrm{HCHS}=$ hatchery spring chinook salmon, $\mathrm{HCHF}=$ hatchery yearling fall chinook salmon,HCHF0 $=$ hatchery subyearling fall chinook salmon, HSTS = hatchery steelhead, $\mathrm{NCH}$ = natural subyearling chinook salmon, NSTS $=$ natural steelhead, and $\mathrm{UCOH}=$ natural and unmarked hatchery coho..

${ }^{b} \mathrm{~N}=$ number of observations.

$c \mathrm{r}=$ correlation coefficient.

$d$ Probability (t-test) that the correlation coefficient is no different from zero; significant $\mathrm{P} \leq 0.05$

Table 22. Correlation between daily PIT-tag detections at RM 3.7 with daily water discharge $\left(\mathrm{ft}^{3} / \mathrm{s}\right)$ from McKay Reservoir, Umatilla River, March - June 2001.

\begin{tabular}{lccc}
\hline Species & $N^{a}$ & $r^{b}$ & $P .05^{c}$ \\
\hline HCHS & 38 & & \\
HCHF & 28 & -0.161 & 0.334 \\
HCHF0 & 11 & 0.428 & 0.023 \\
HCOH & 32 & -0.354 & 0.285 \\
HSTS (large) & 36 & 0.170 & 0.353 \\
HSTS (small) & 26 & 0.104 & 0.547 \\
NCH (yearling) & 44 & 0.202 & 0.323 \\
NCH (subyearling) & 31 & 0.408 & 0.006 \\
NCOH & 3 & 0.376 & 0.037 \\
NSTS & 59 & - & - \\
\hline
\end{tabular}

${ }_{a} \mathrm{~N}=$ number of observations.

${ }^{b} \mathrm{r}=$ correlation coefficient.

$c$ Probability (t-test) that the correlation coefficient is no different from zero; significant $\mathrm{P} \leq 0.05$.

$d$ Natural chinook salmon are likely of spring race due to tagging location, size at time of tagging, and migration timing.

$e$ Natural chinook salmon are a mix of spring and fall race subyearlings. This group of fish were not PIT tagged. Numbers used for analysis were fish captured during timed subsamples at RM 3.7. 


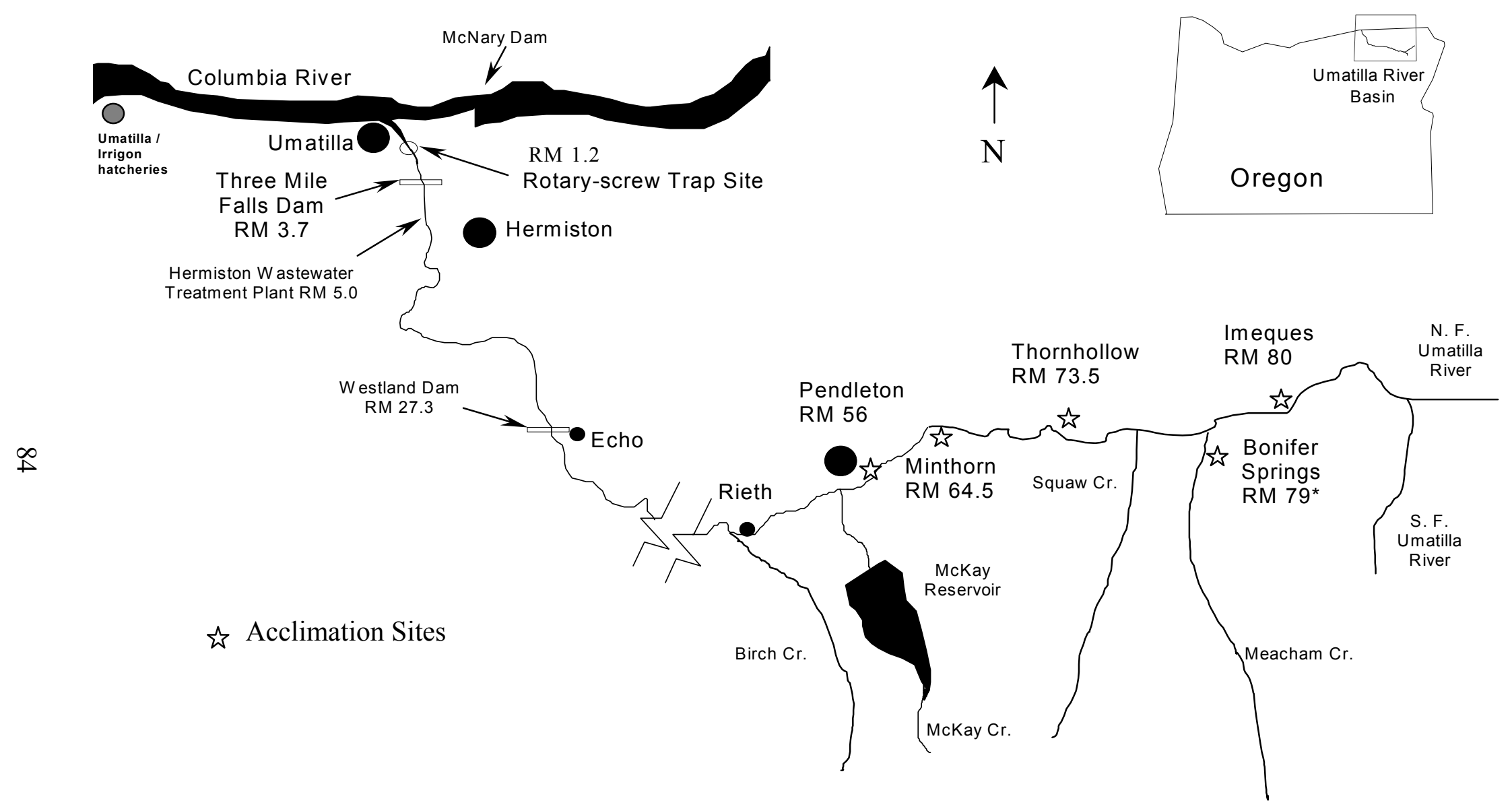

Figure 1. Detailed study area map and release locations, Umatilla River 2001. 


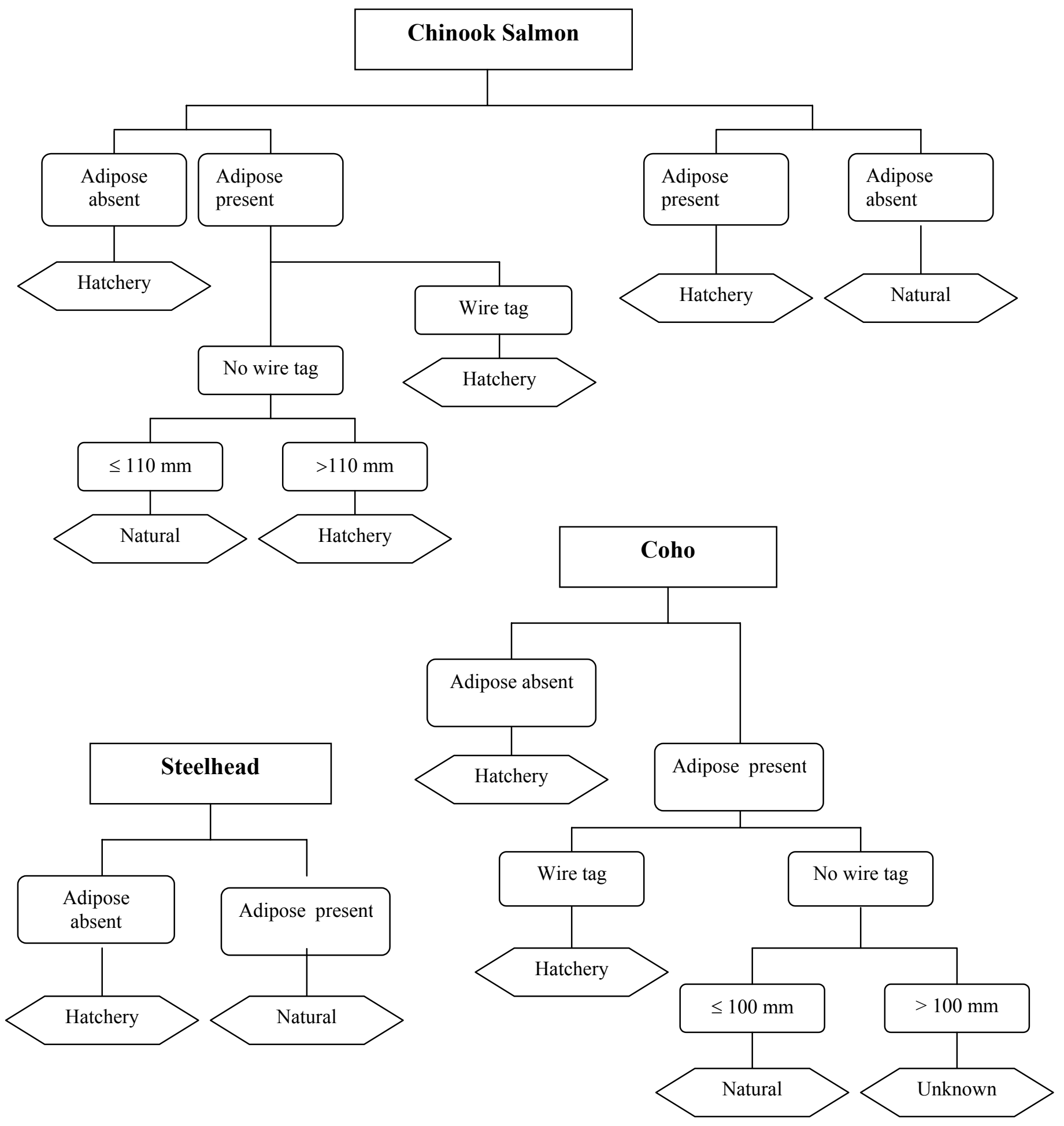

Figure 2. Parameters used to identify the origin of juvenile salmonids, Umatilla River, 2001. 


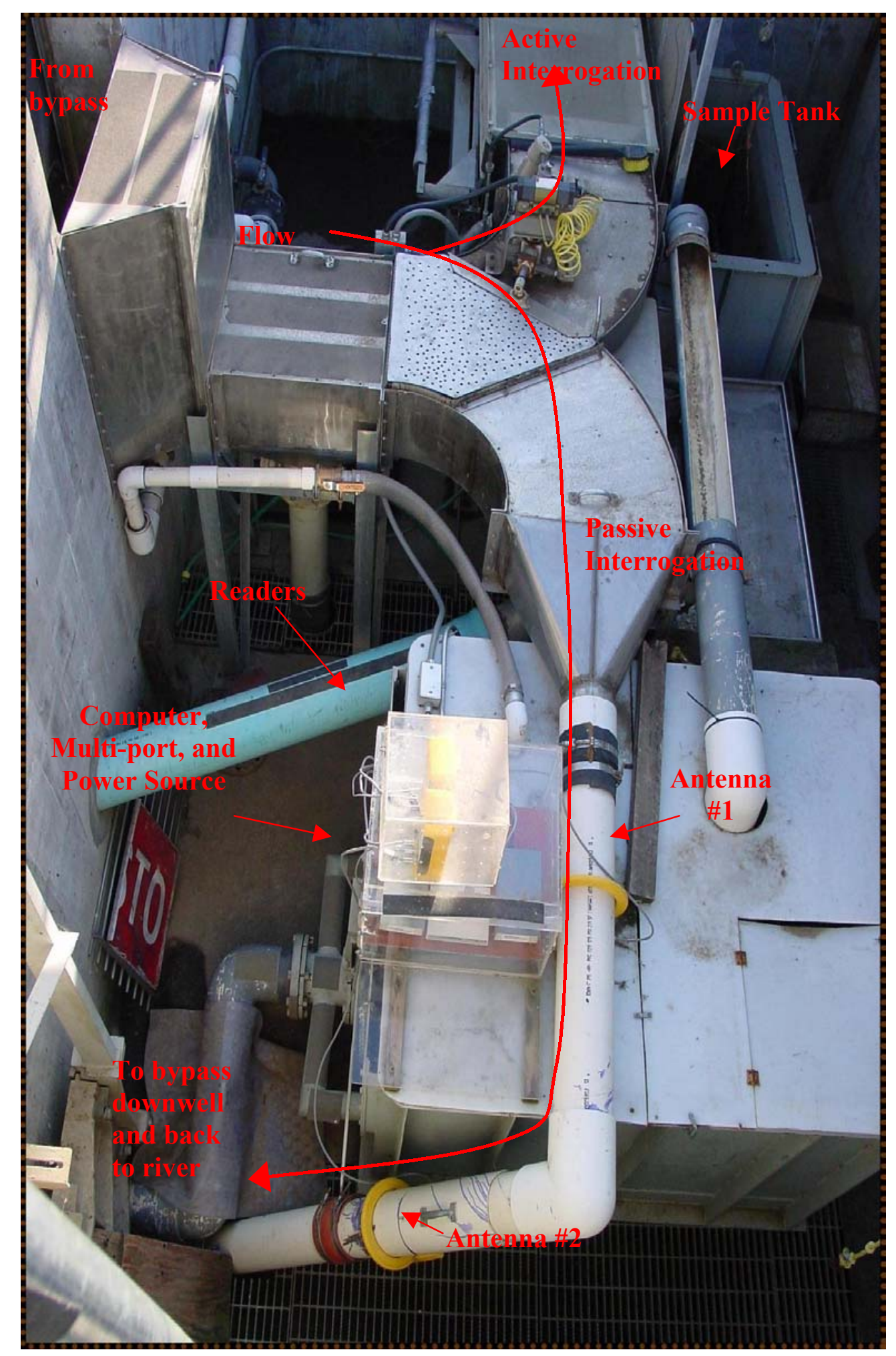

Figure 3. Remote PIT-tag interrogation system (134 kHz) used at West Extension Canal (RM 3.7) in 2001. 


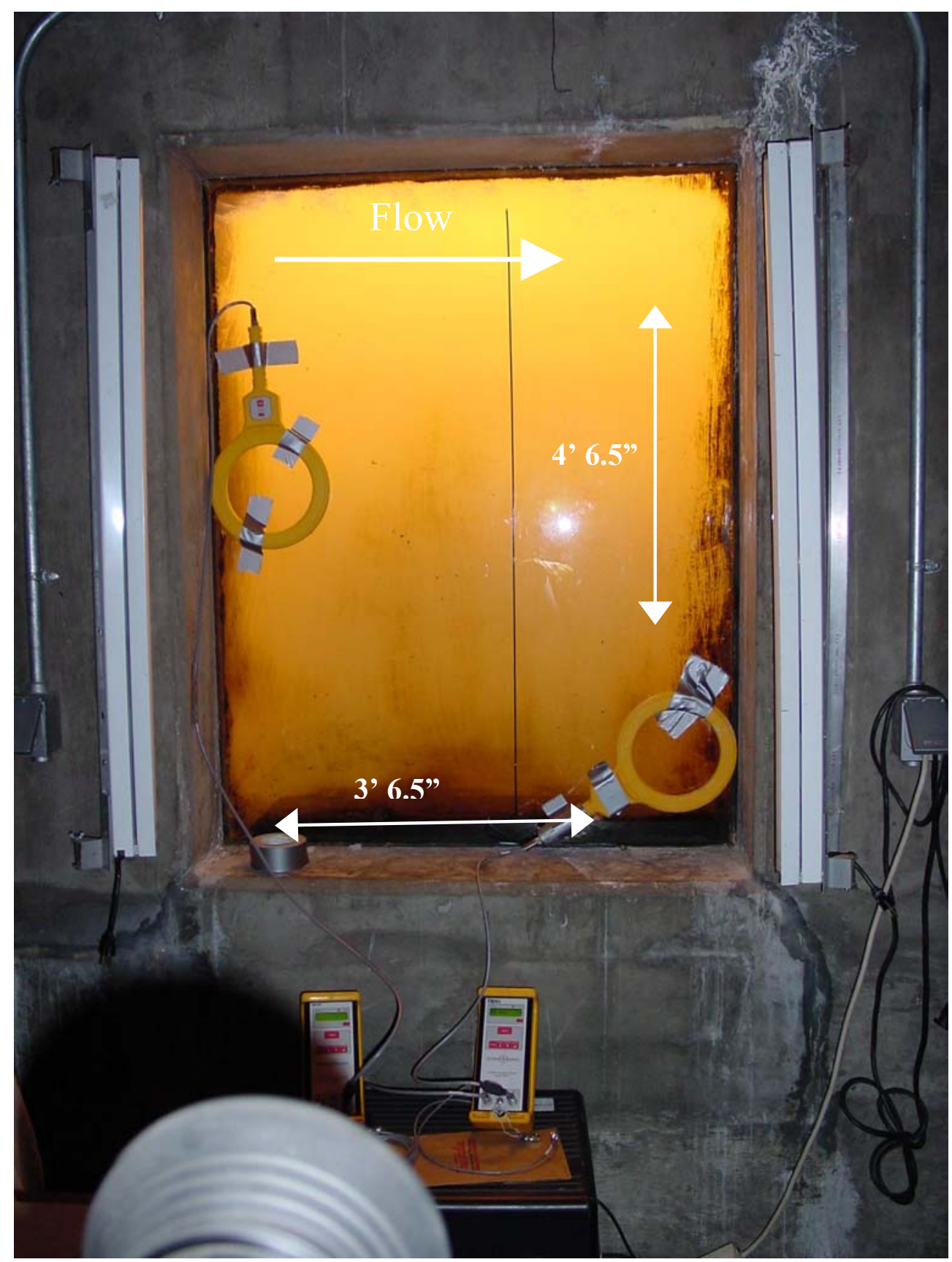

Figure 4. Temporary set up of portable detection system at east-bank viewing window, Three Mile Falls Dam (RM 3.7), lower Umatilla River. 


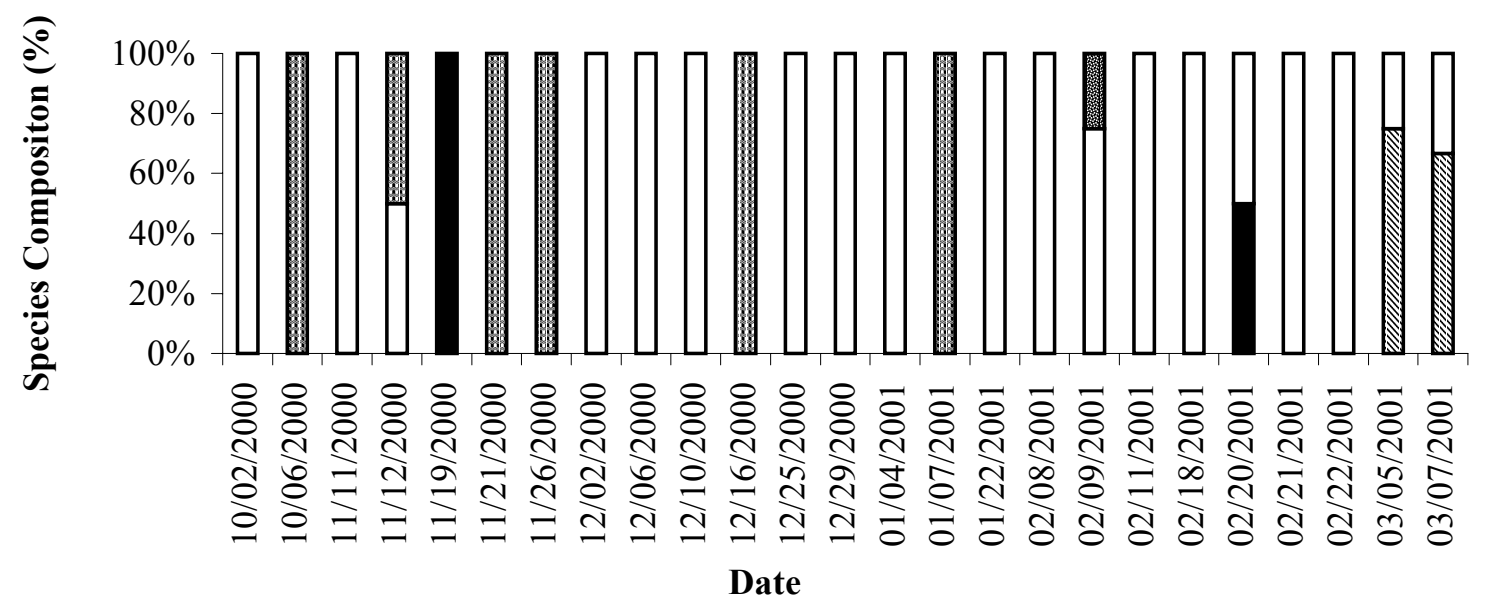

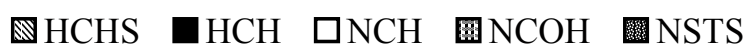

Figure 5. Daily species composition of juvenile salmonids sampled at RM 1.2, Umatilla River, October 2000 - March 2001. 


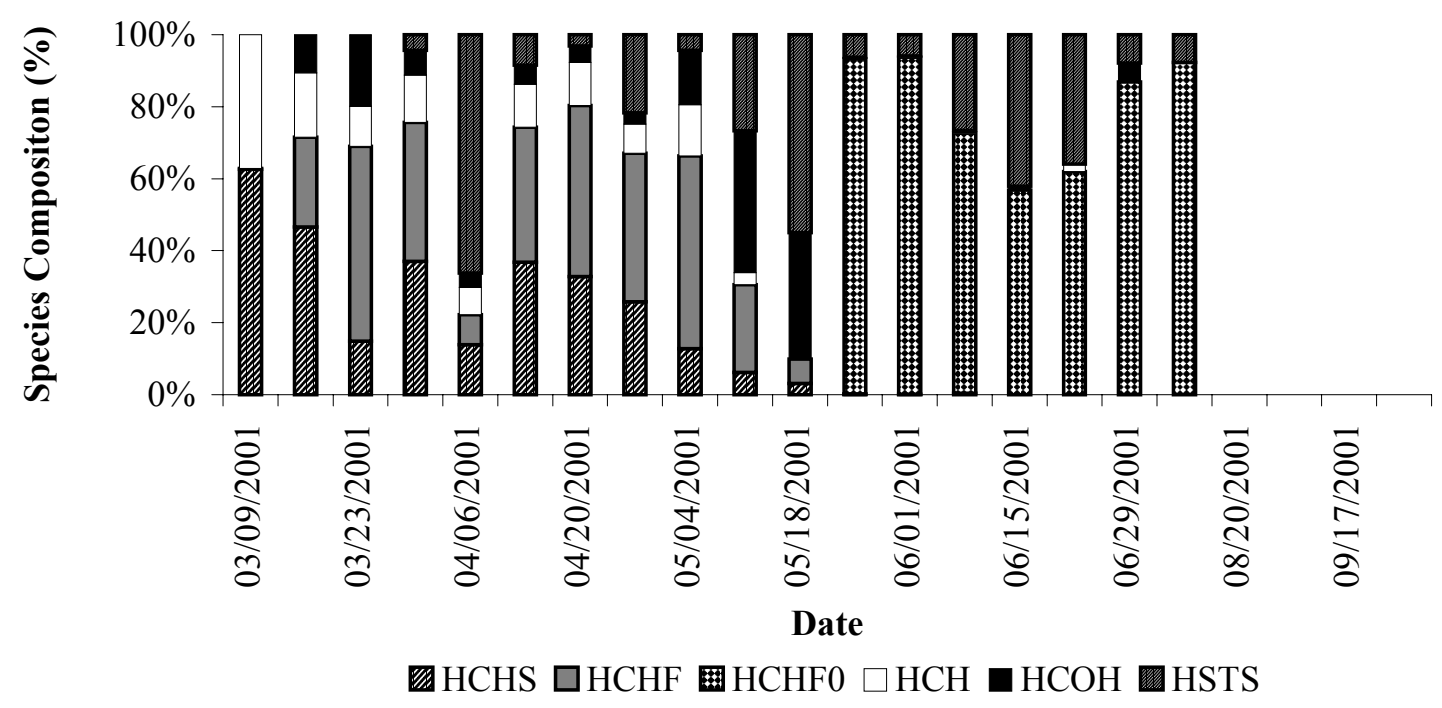

Figure 6. Weekly species composition of hatchery juvenile salmonids sampled at RM 3.7, Umatilla River, March - September 2001.

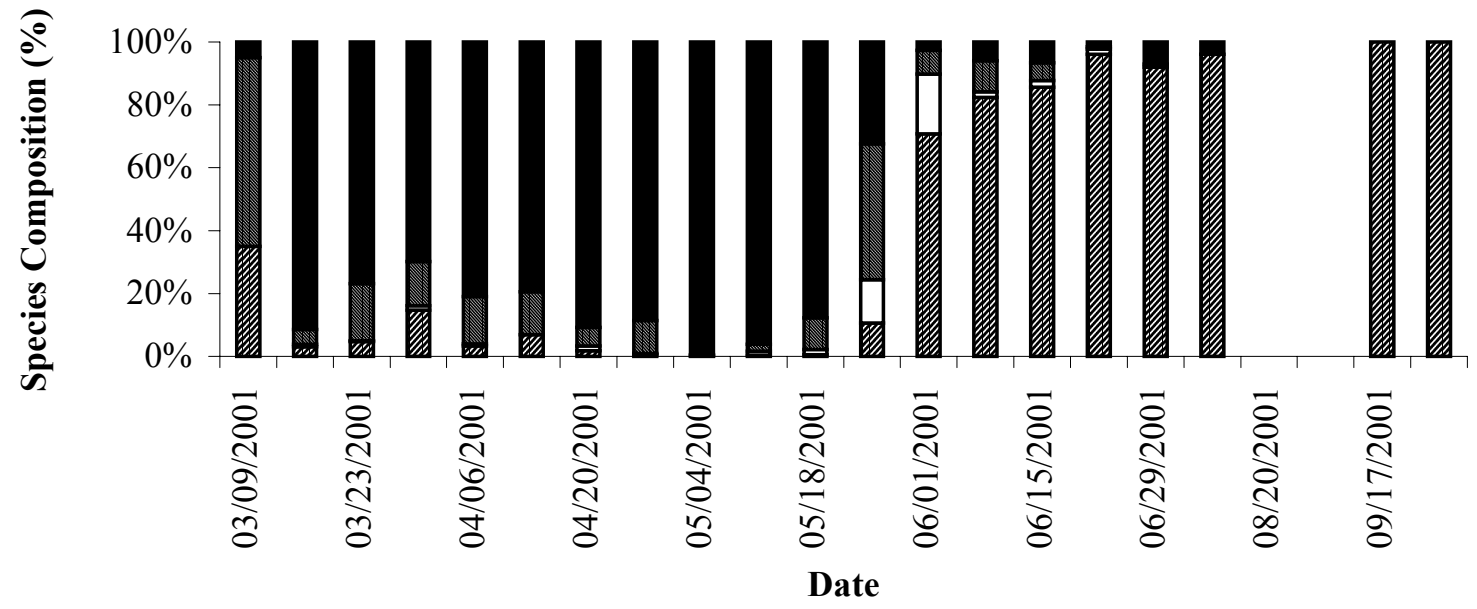

\section{NCH $\square \mathrm{NCOH}$ NSTS $\boldsymbol{\mathrm { NCOH }}$}

Figure 7. Weekly species composition of natural and unknown juvenile salmonids sampled at RM 3.7, Umatilla River, March - September 2001. 


\section{Hatchery Spring Chinook Salmon}

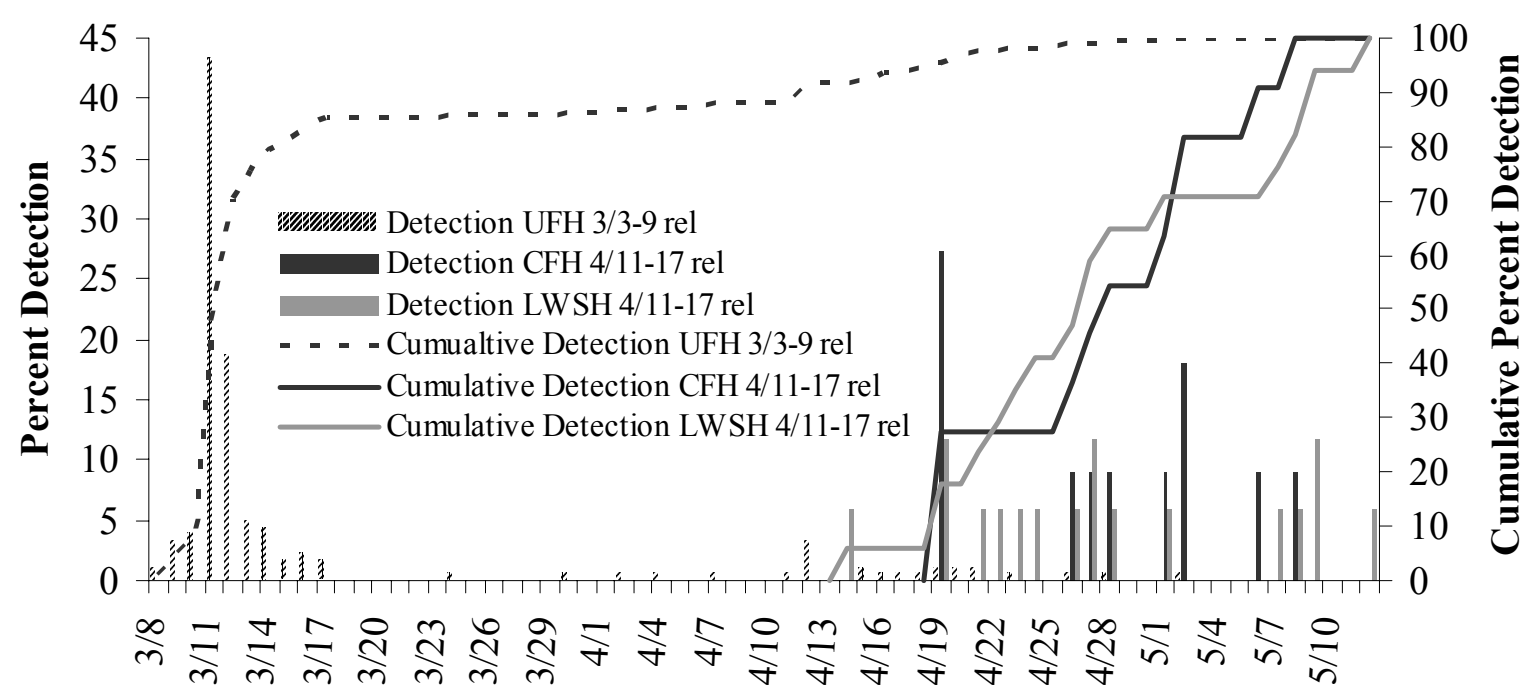

Date

\section{Natural Spring Chinook Salmon}

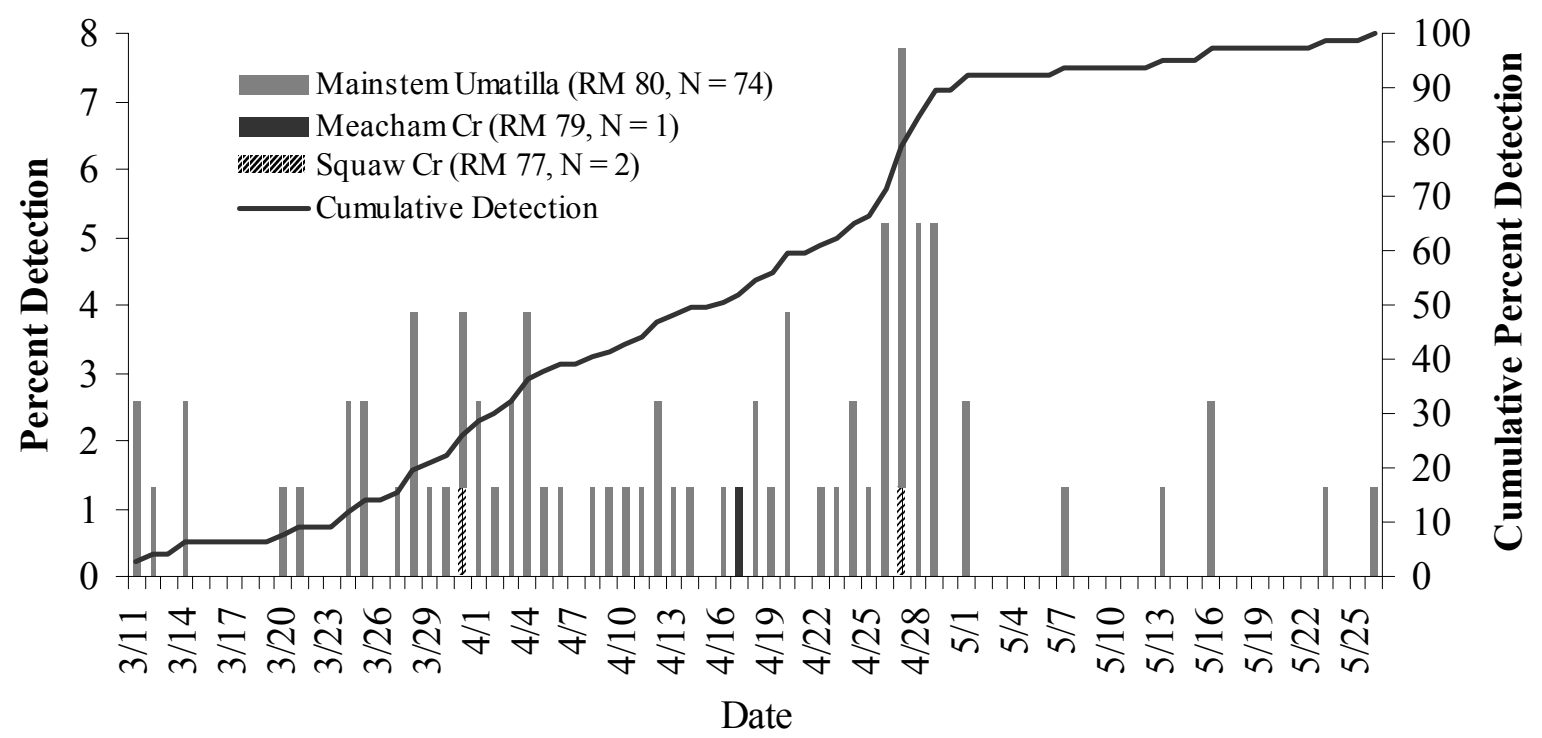

Figure 8. Percent and cumulative percent detection of PIT-tagged hatchery and natural spring chinook salmon at RM 3.7, Umatilla River, March - May 2001. 


\section{Hatchery Spring Chinook Salmon}

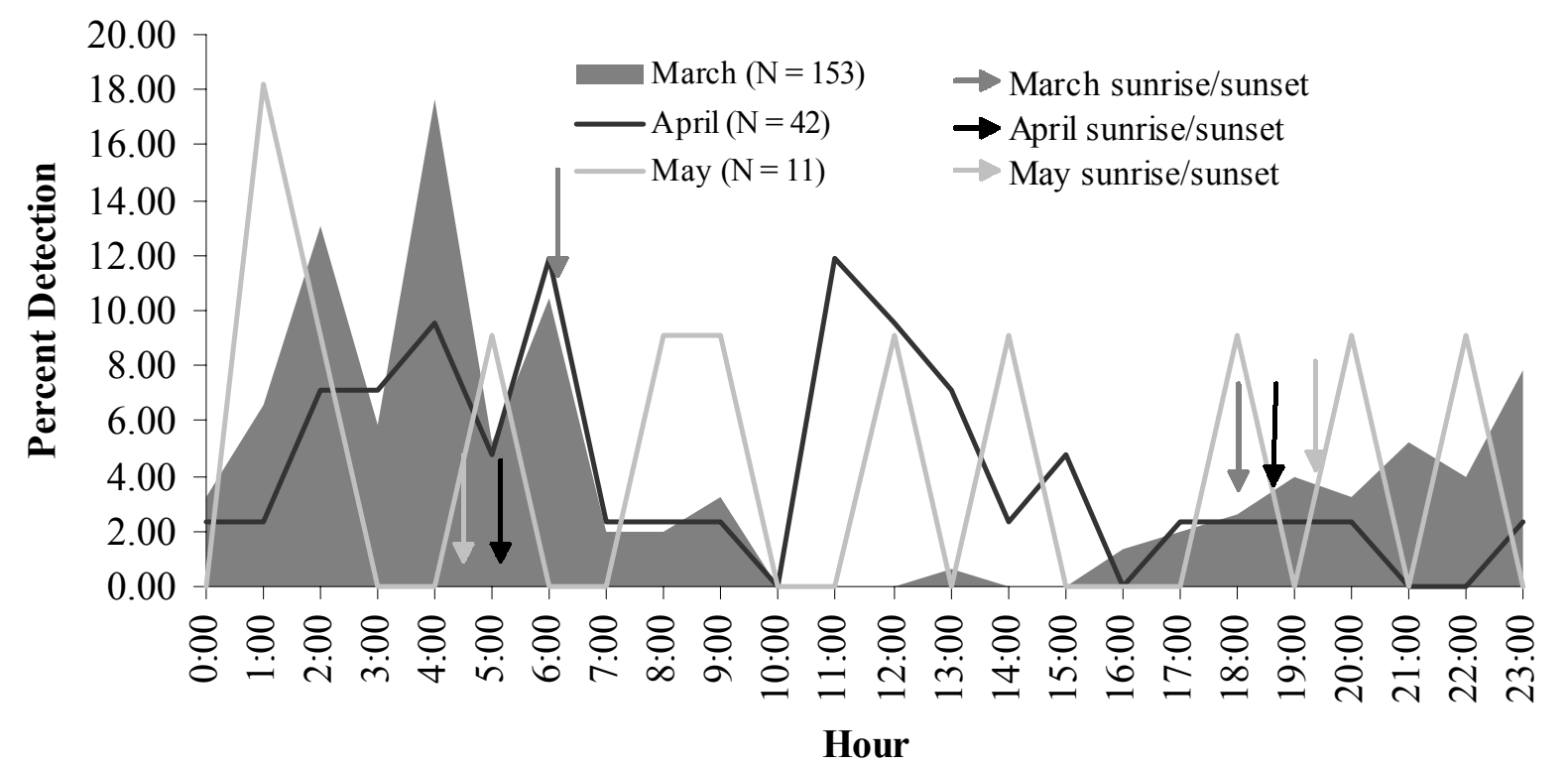

\section{Natural Spring Chinook Salmon}

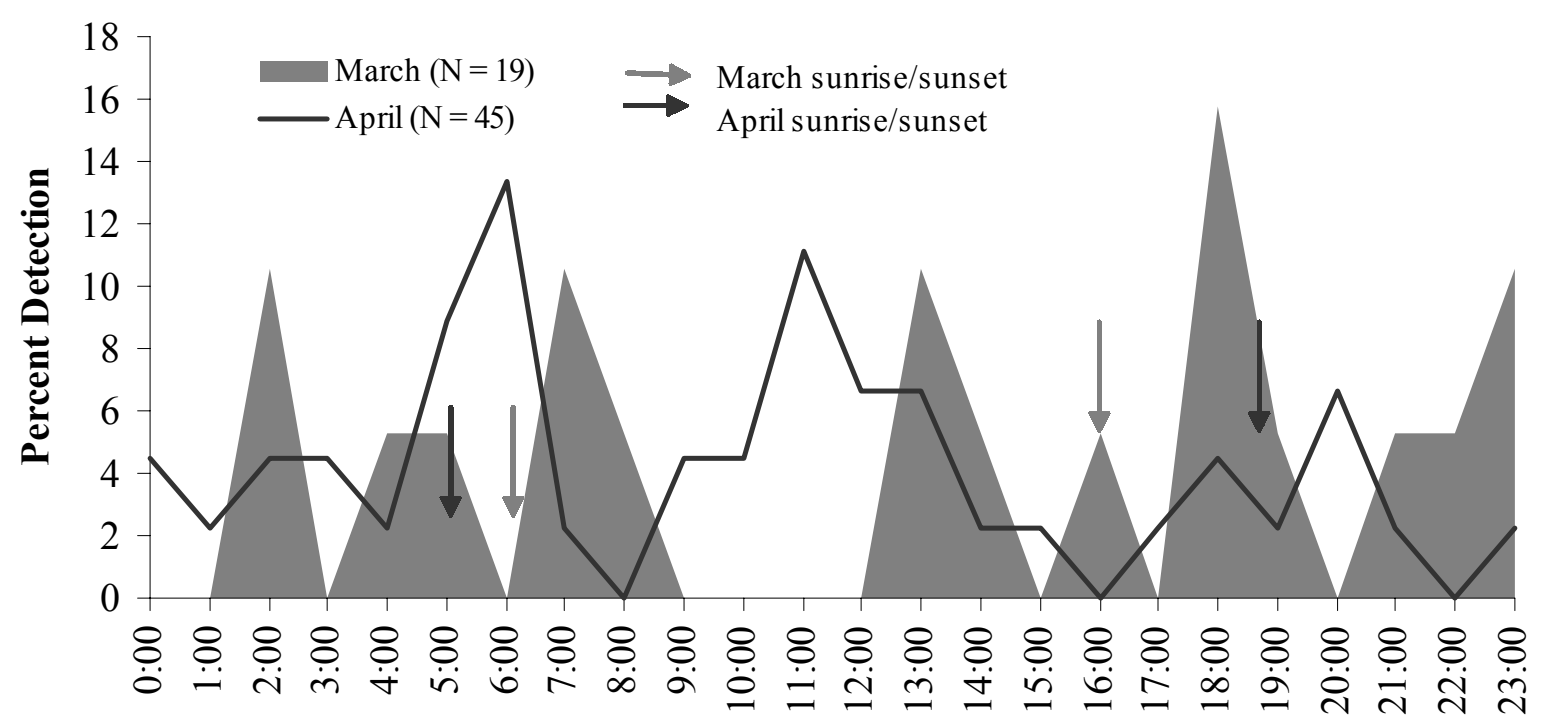

Hour

Figure 9. Diel detection of PIT-tagged hatchery and natural spring chinook salmon at RM 3.7, Umatilla River, March - May 2001. 


\section{Yearling Fall Chinook Salmon}

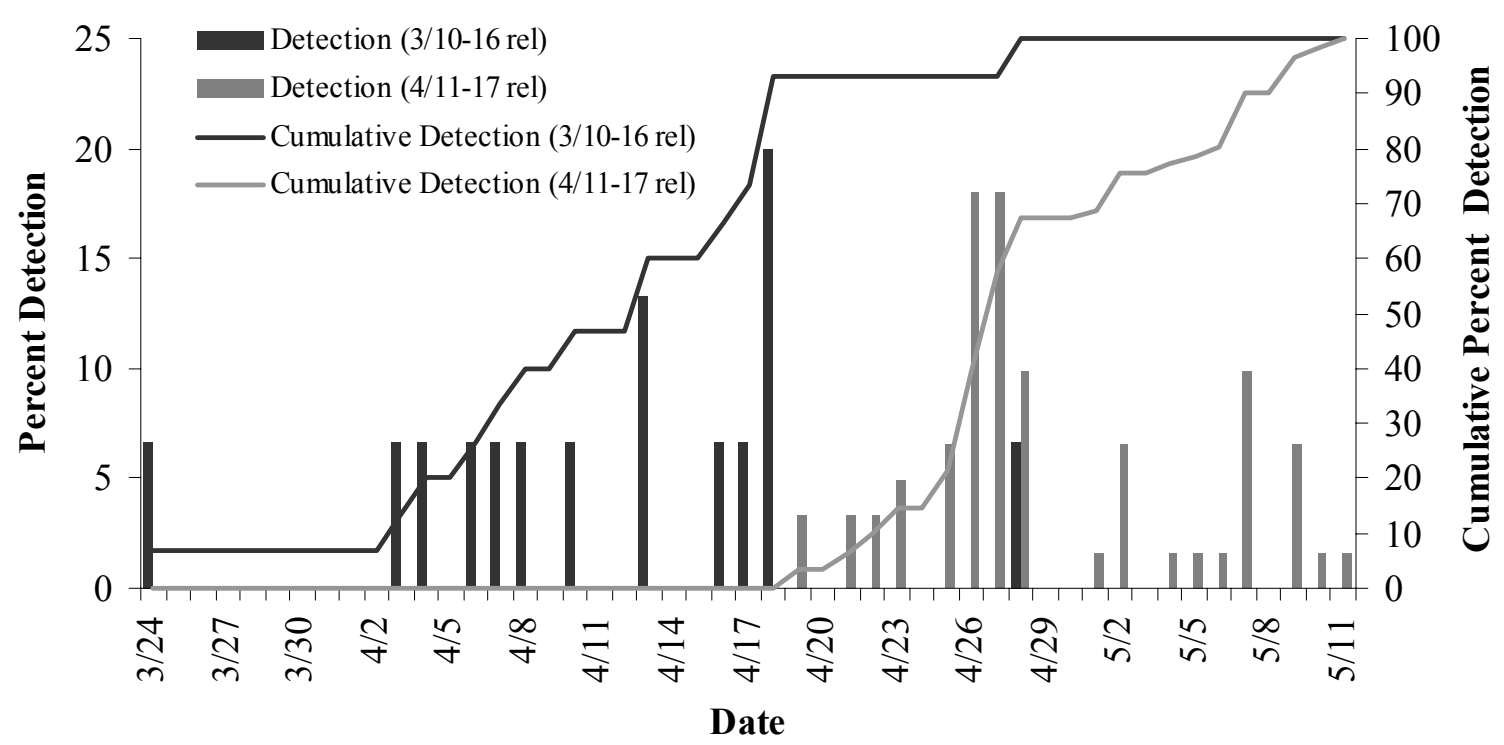

\section{Subyearling Fall Chinook Salmon}

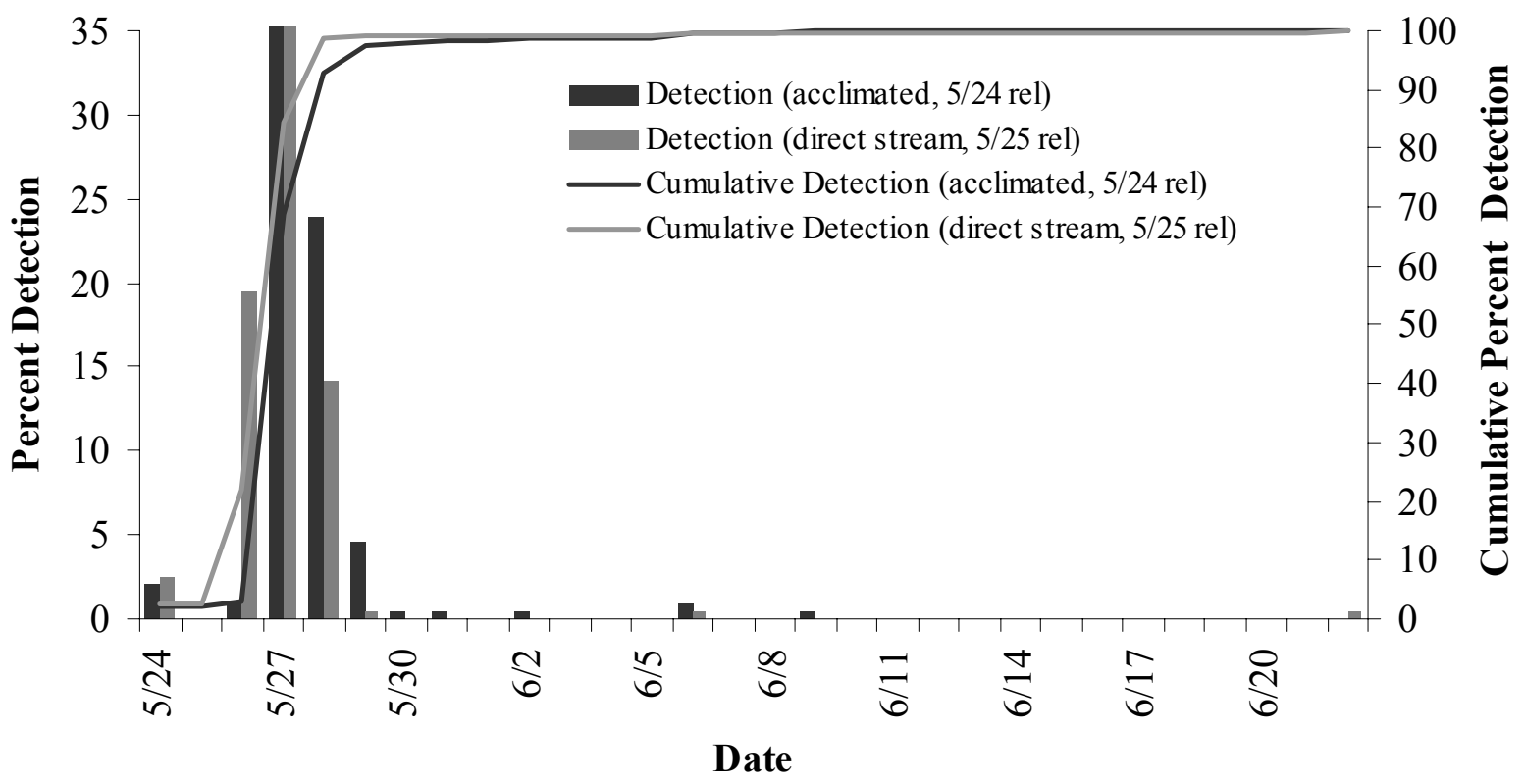

Figure 10. Percent and cumulative percent detection of PIT-tagged hatchery yearling and subyearling fall chinook salmon at RM 3.7, Umatilla River, March - June 2001. 


\section{Hatchery Yearling Fall Chinook Salmon}

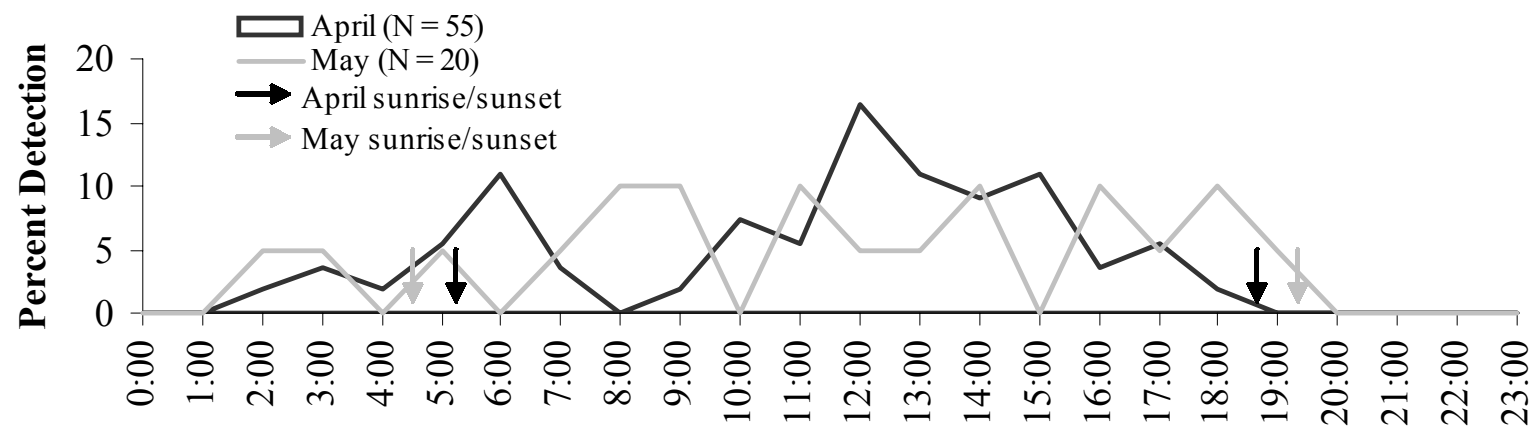

Hour

\section{Hatchery Subyearling Fall Chinook Salmon}

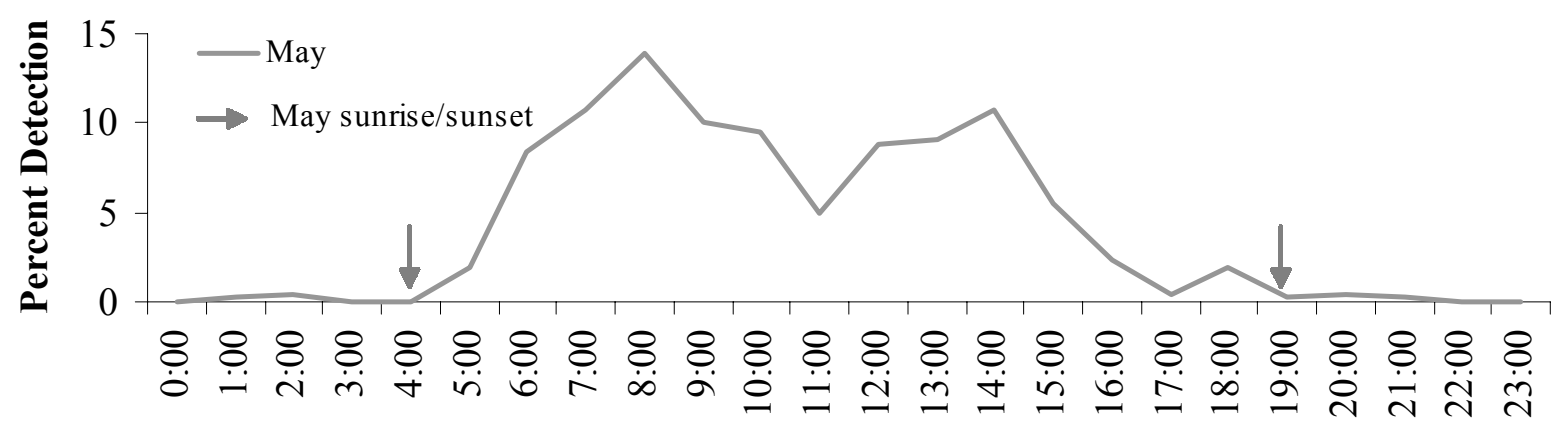

Hour

\section{Hatchery Coho Salmon}

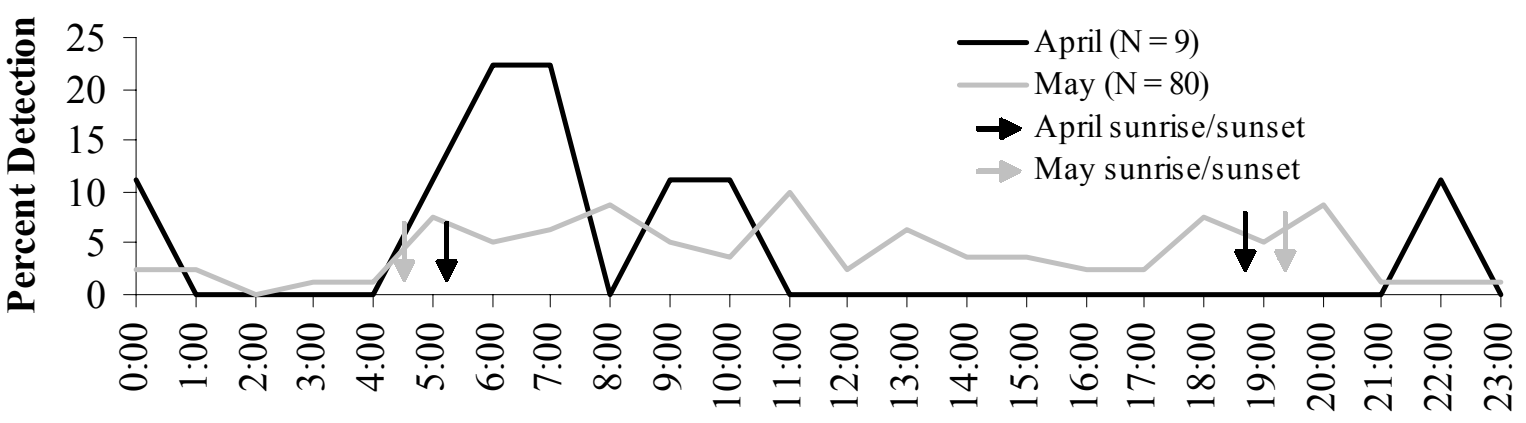

Hour

Figure 11. Diel detection of PIT-tagged hatchery yearling and subyearling fall chinook salmon and coho salmon at RM 3.7, Umatilla River, March - May 2001. 


\section{Hatchery Coho Salmon}

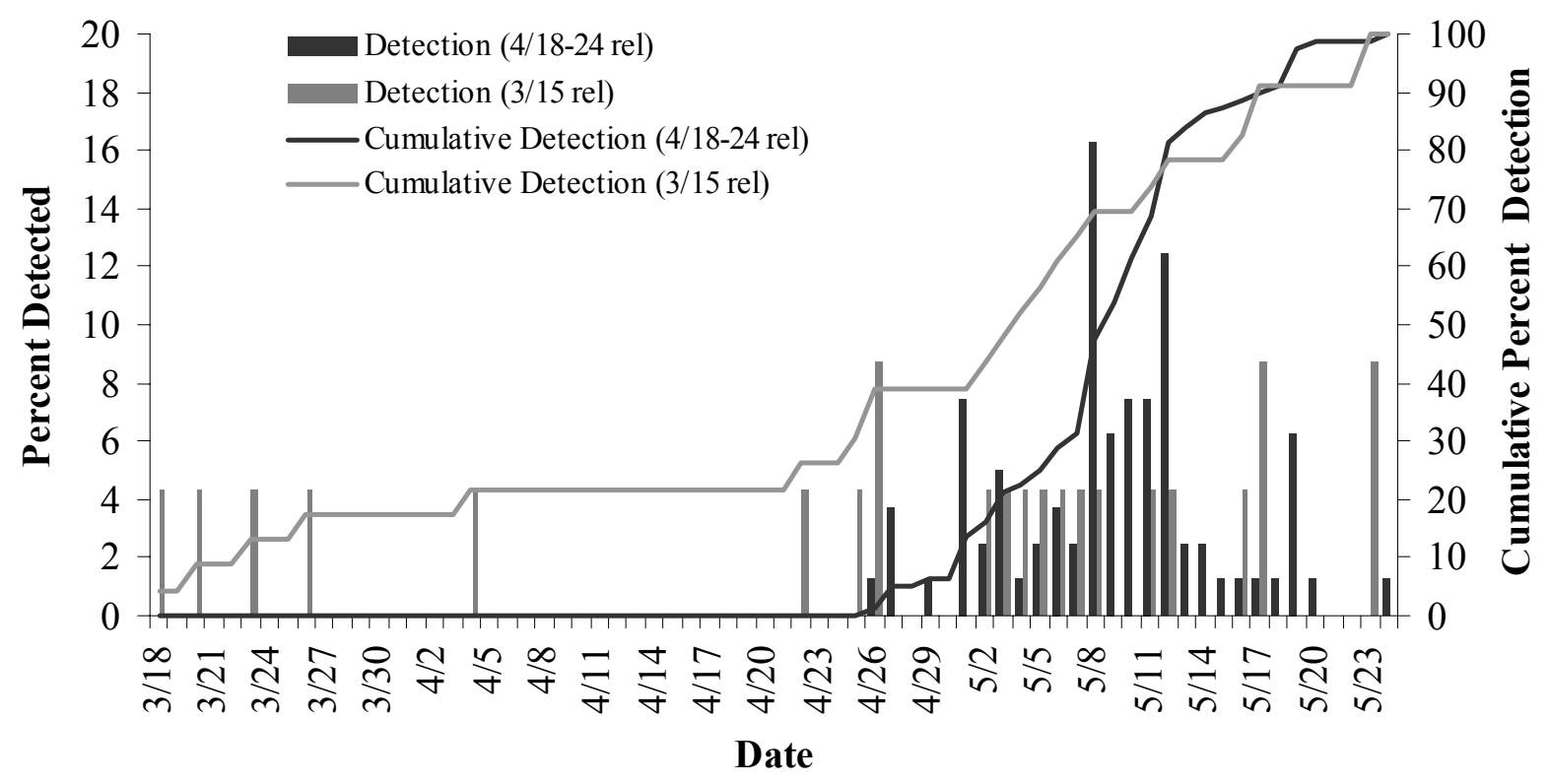

Figure 12. Percent and cumulative percent detection of PIT-tagged hatchery coho salmon at RM 3.7, Umatilla River, March - May 2001. 


\section{Hatchery Summer Steelhead}

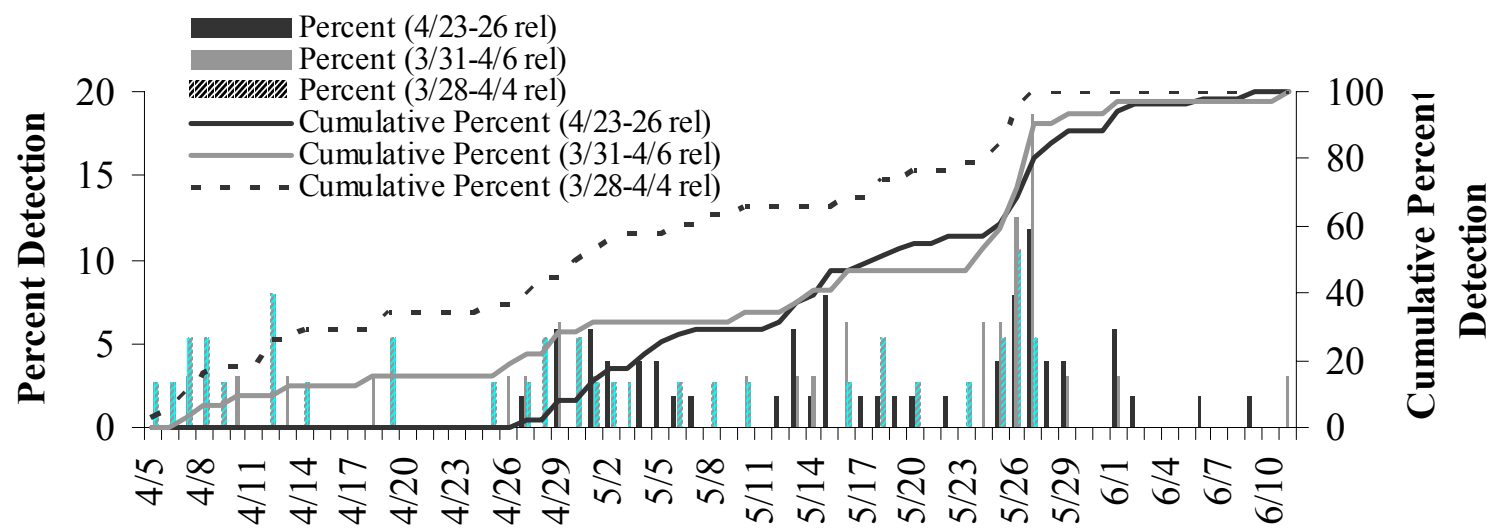

\section{Hatchery Small-Grade Test}

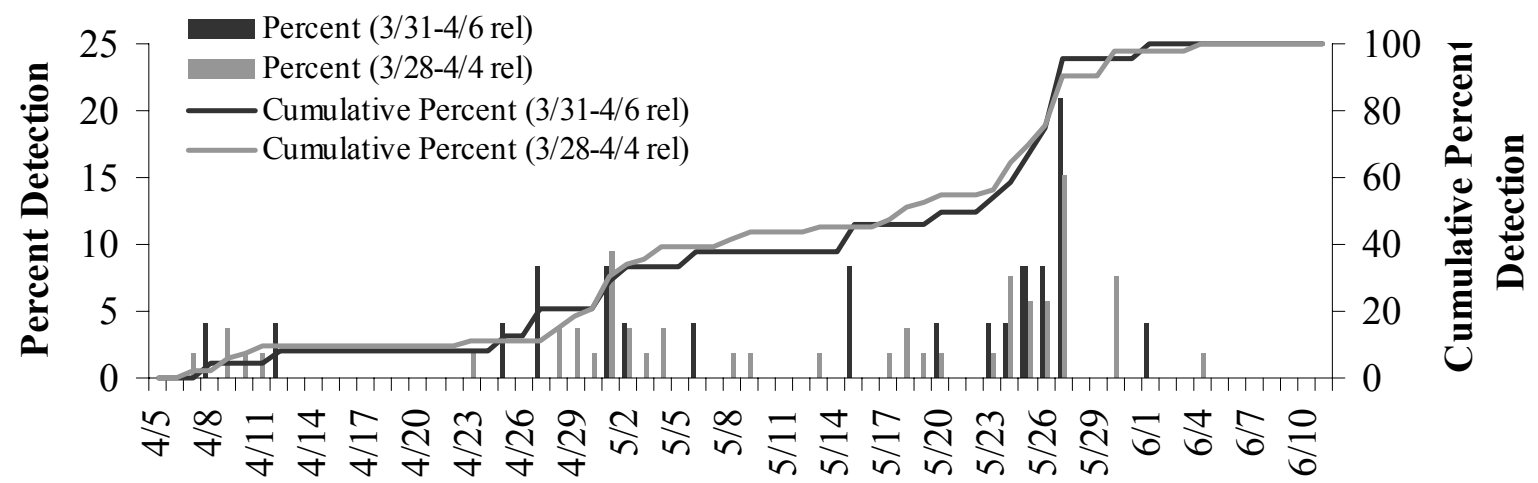

Natural Summer Steelhead

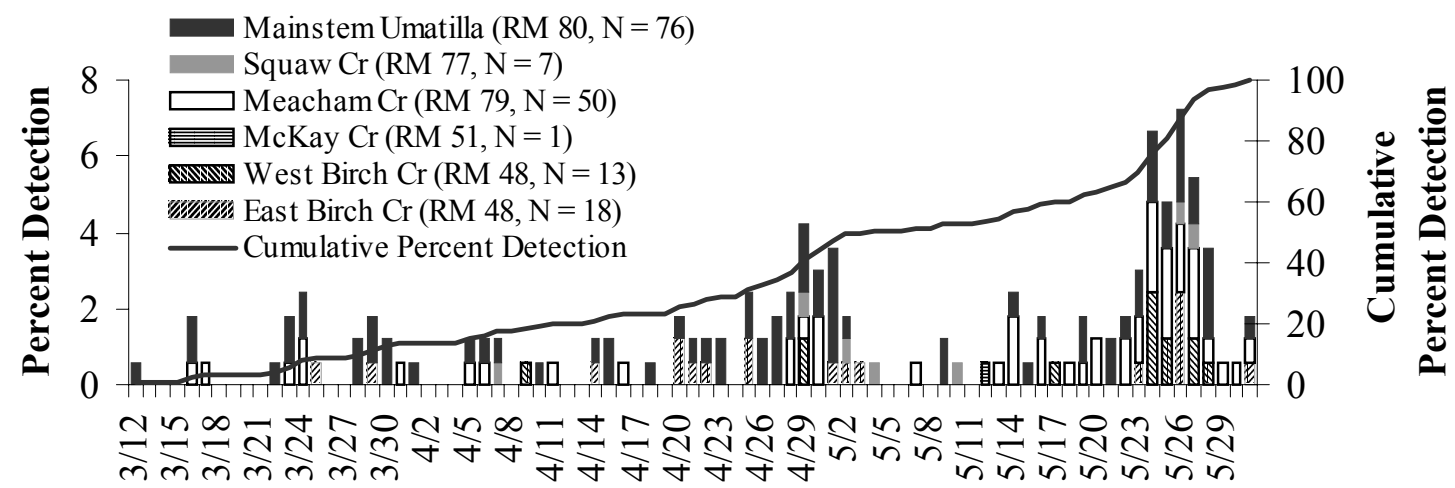

Date

Figure 13. Percent and cumulative percent detection of PIT-tagged hatchery and natural summer steelhead at RM 3.7, Umatilla River, March - June 2001. 


\section{Hatchery Summer Steelhead}

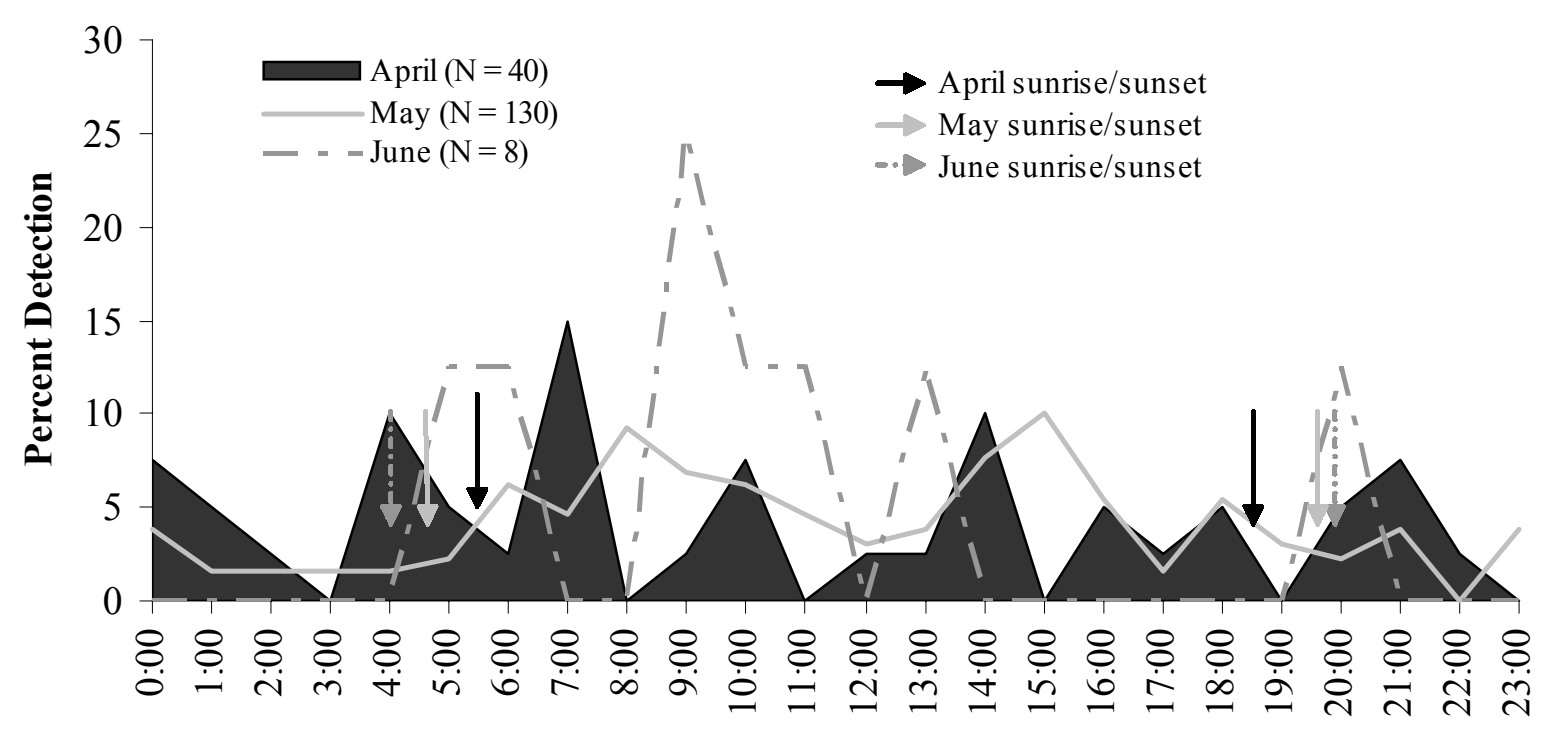

Hour

\section{Natural Summer Steelhead}

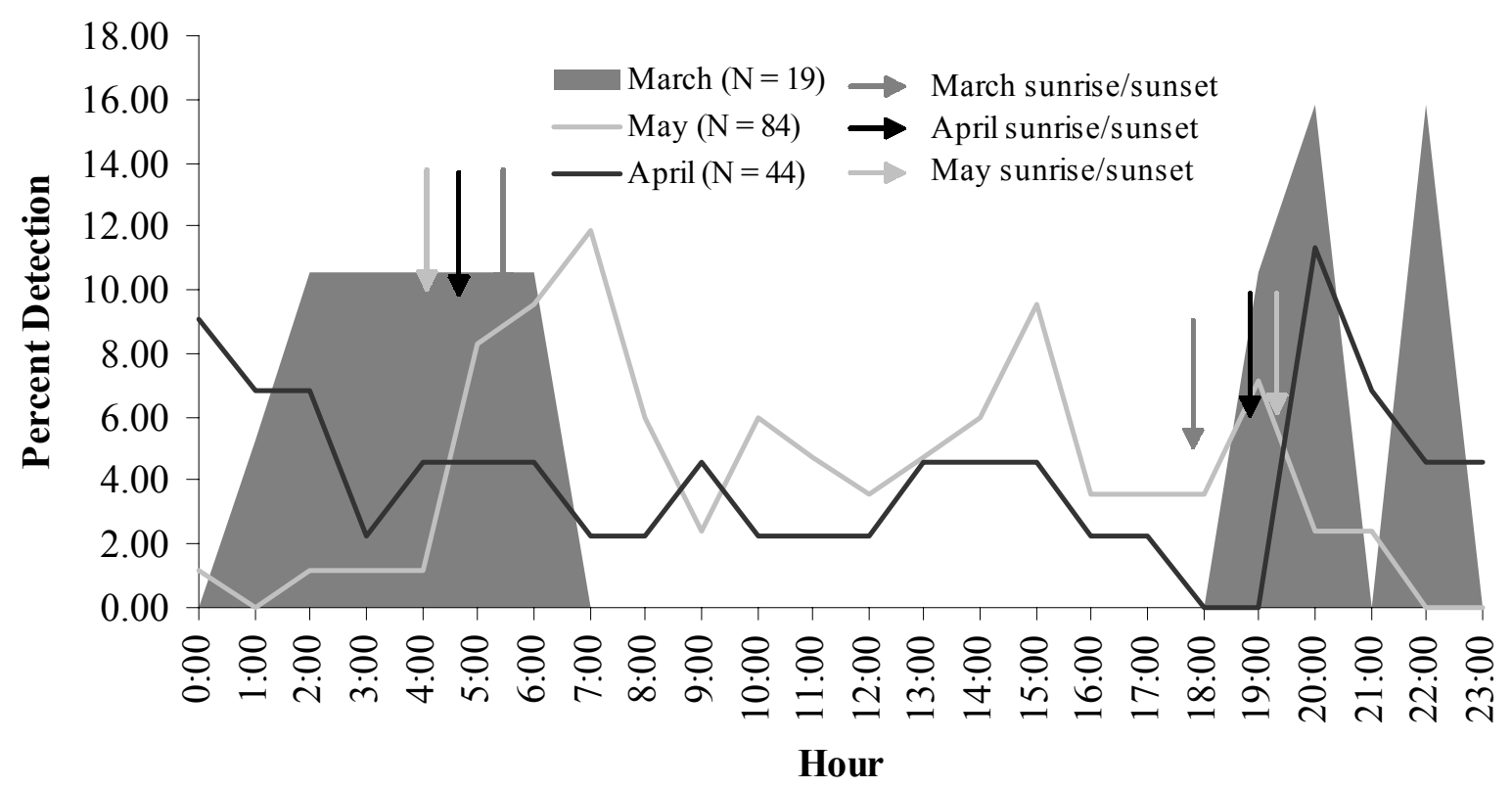

Figure 14. Diel detection of PIT-tagged hatchery and natural summer steelhead at RM 3.7, Umatilla River, March - June 2001. 


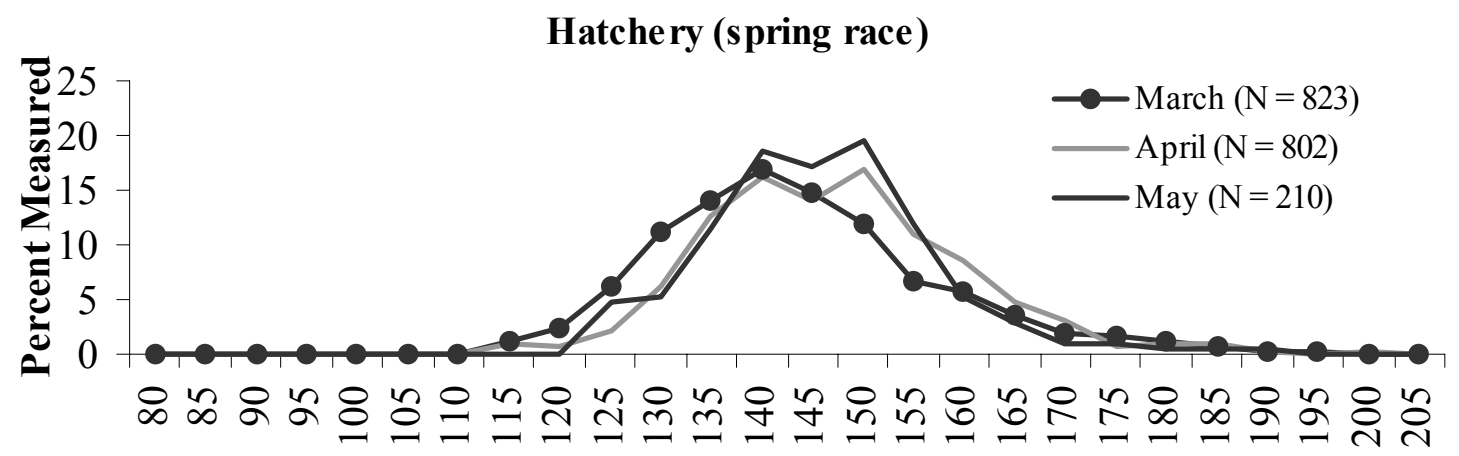

Hatchery (unknown race)
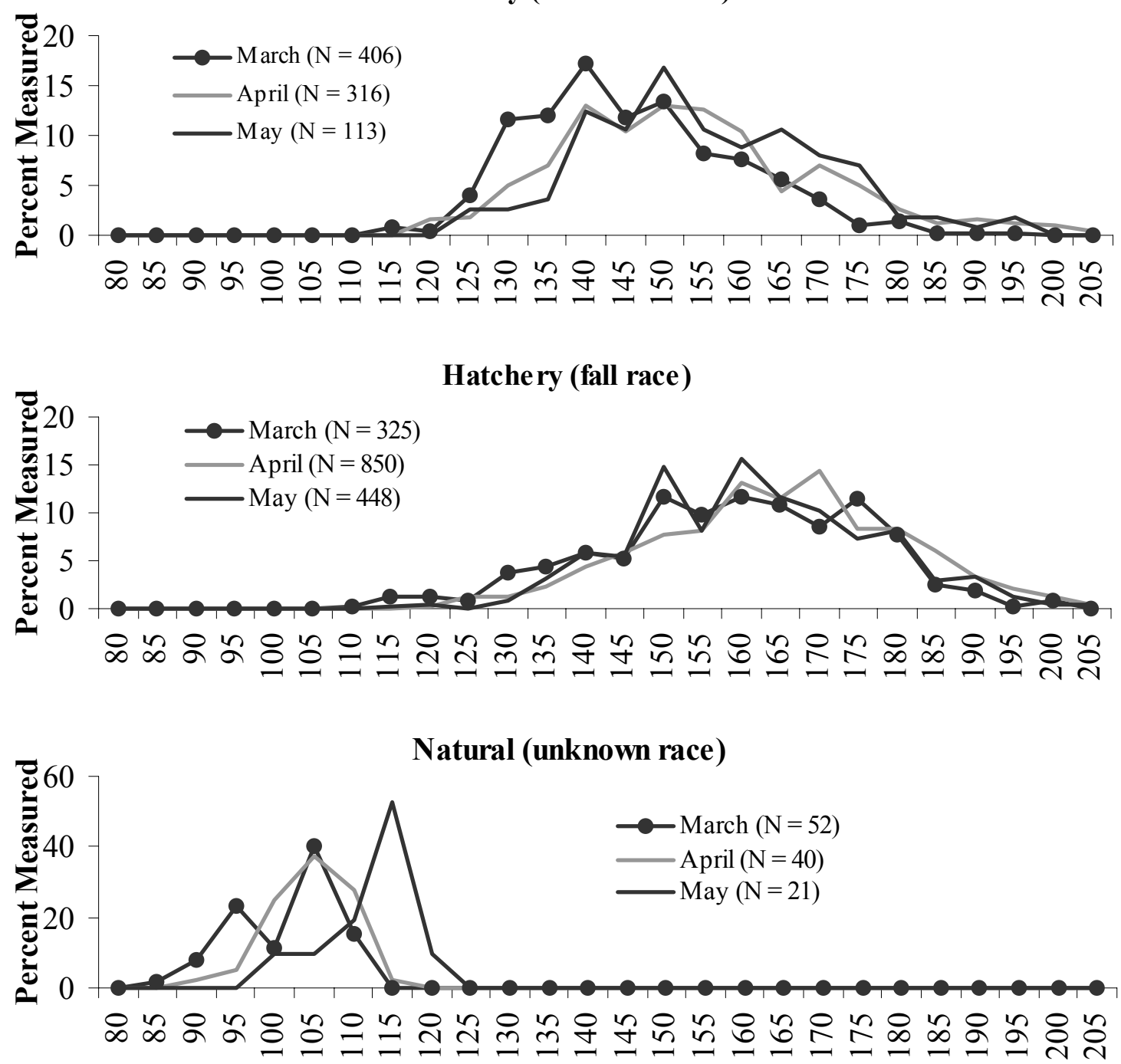

Fork Length (mm)

Figure 15. Length frequency distribution of yearling hatchery and natural chinook salmon of spring, fall, and unknown races captured at RM 3.7, Umatilla River, March - May 2001. 


\section{Hatchery (fall race)}

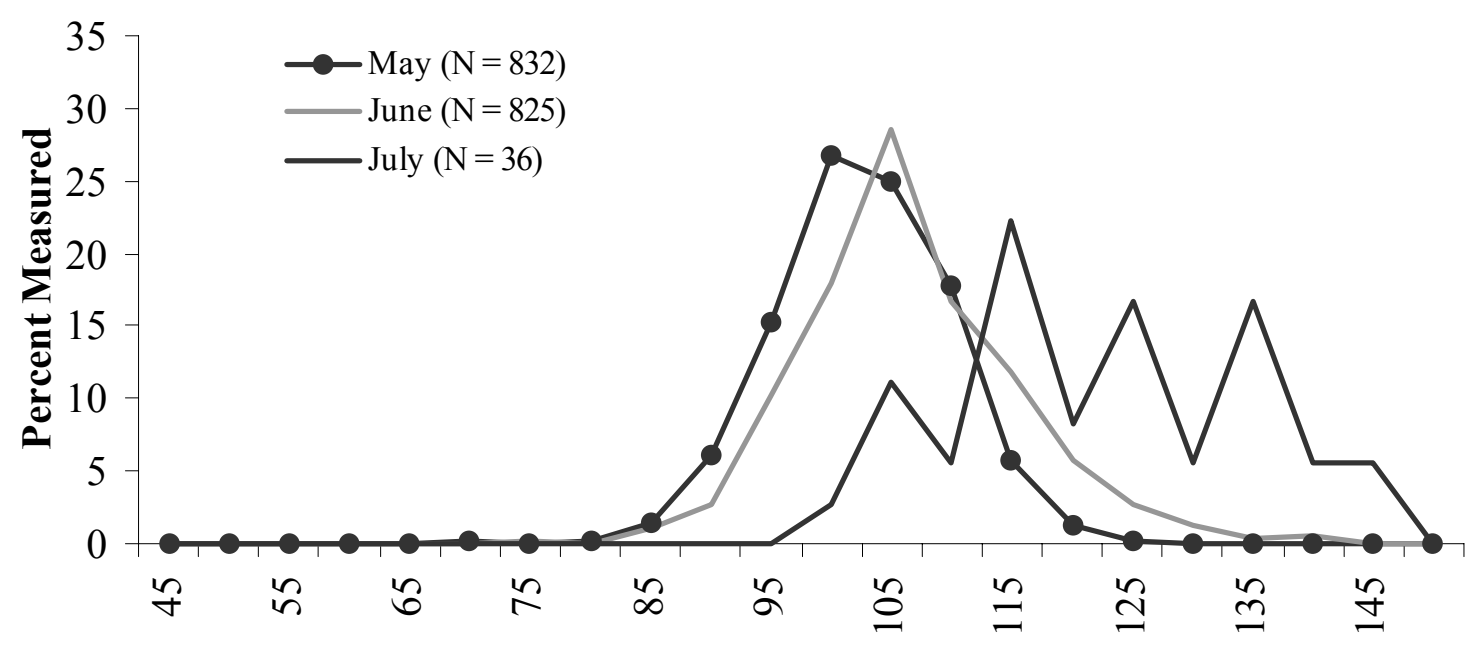

Fork Length (mm)

\section{Natural (unknown race)}

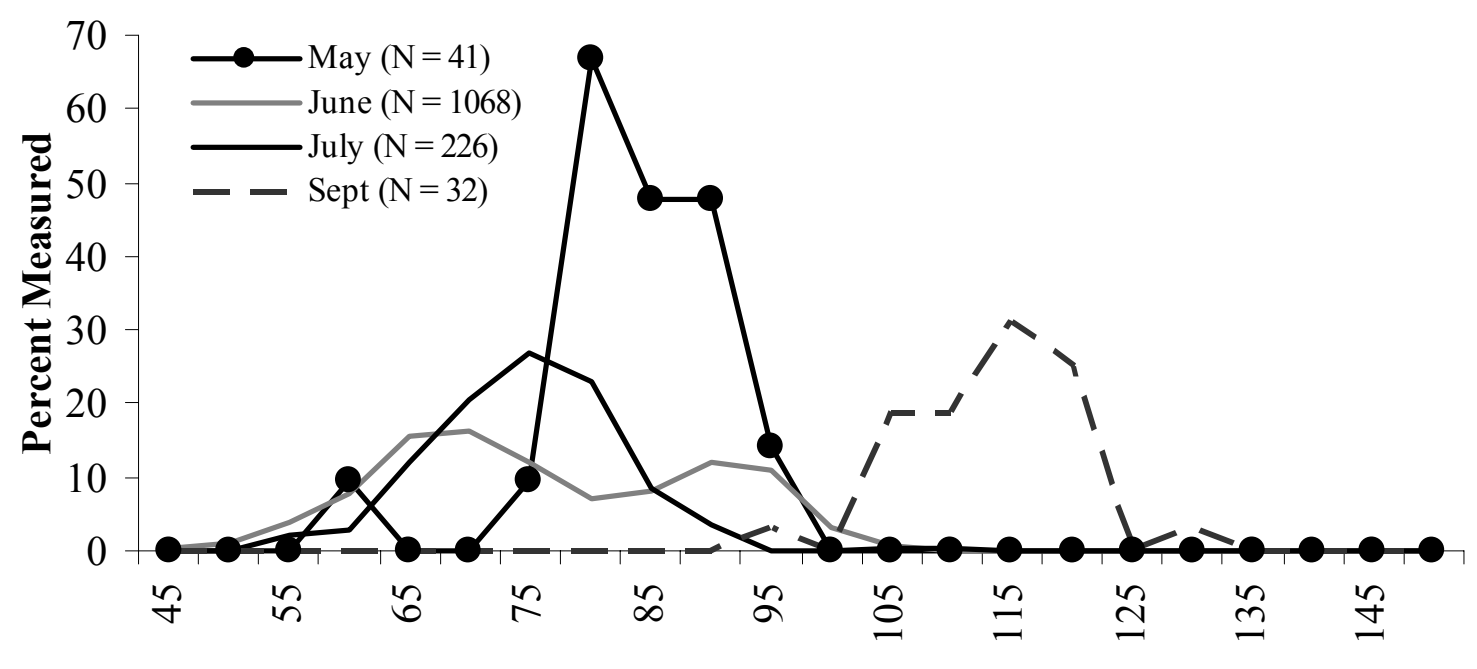

Fork Length (mm)

Figure 16. Length frequency distribution of hatchery and natural subyearling chinook salmon of fall and unknown race captured at RM 3.7, Umatilla River, May - September2001. 


\section{Hatchery}

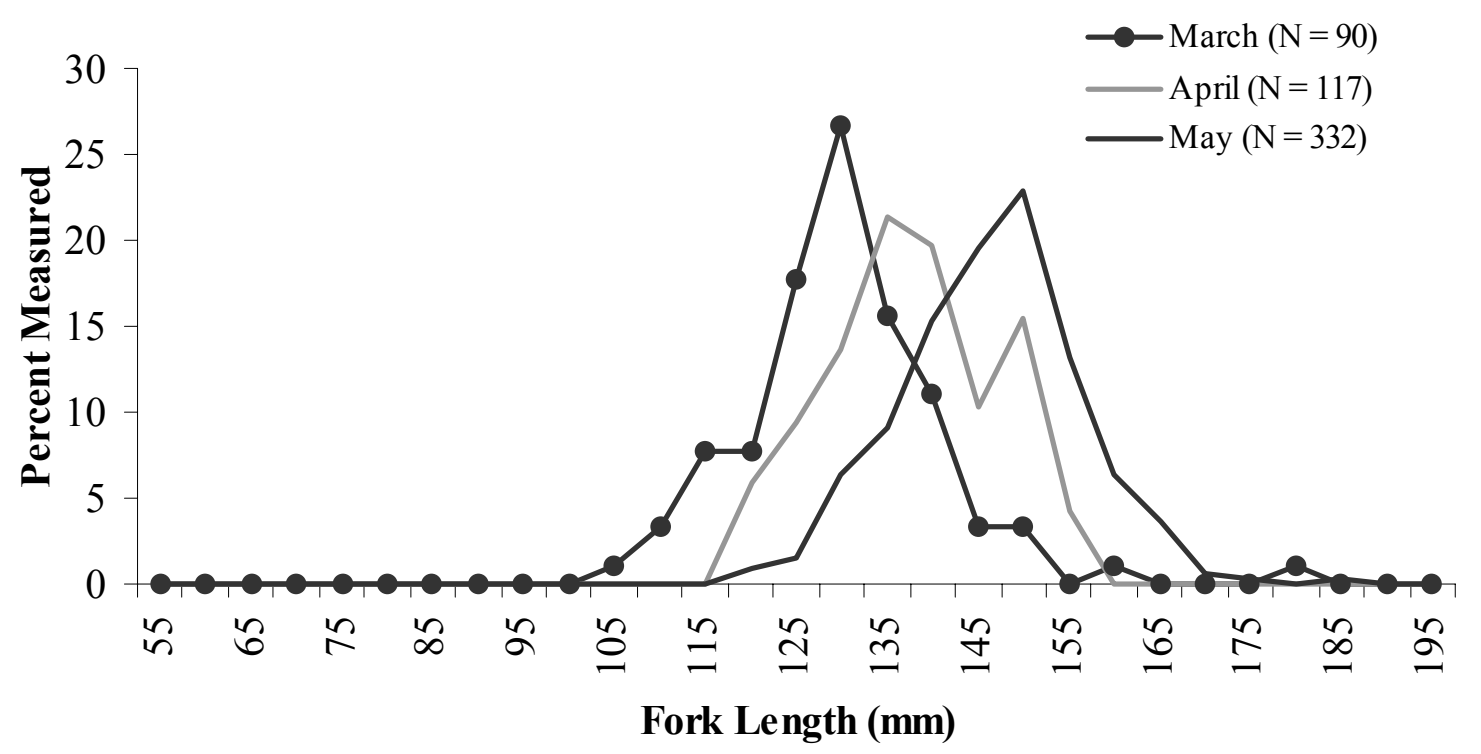

Unmarked (hatchery and natural origin)

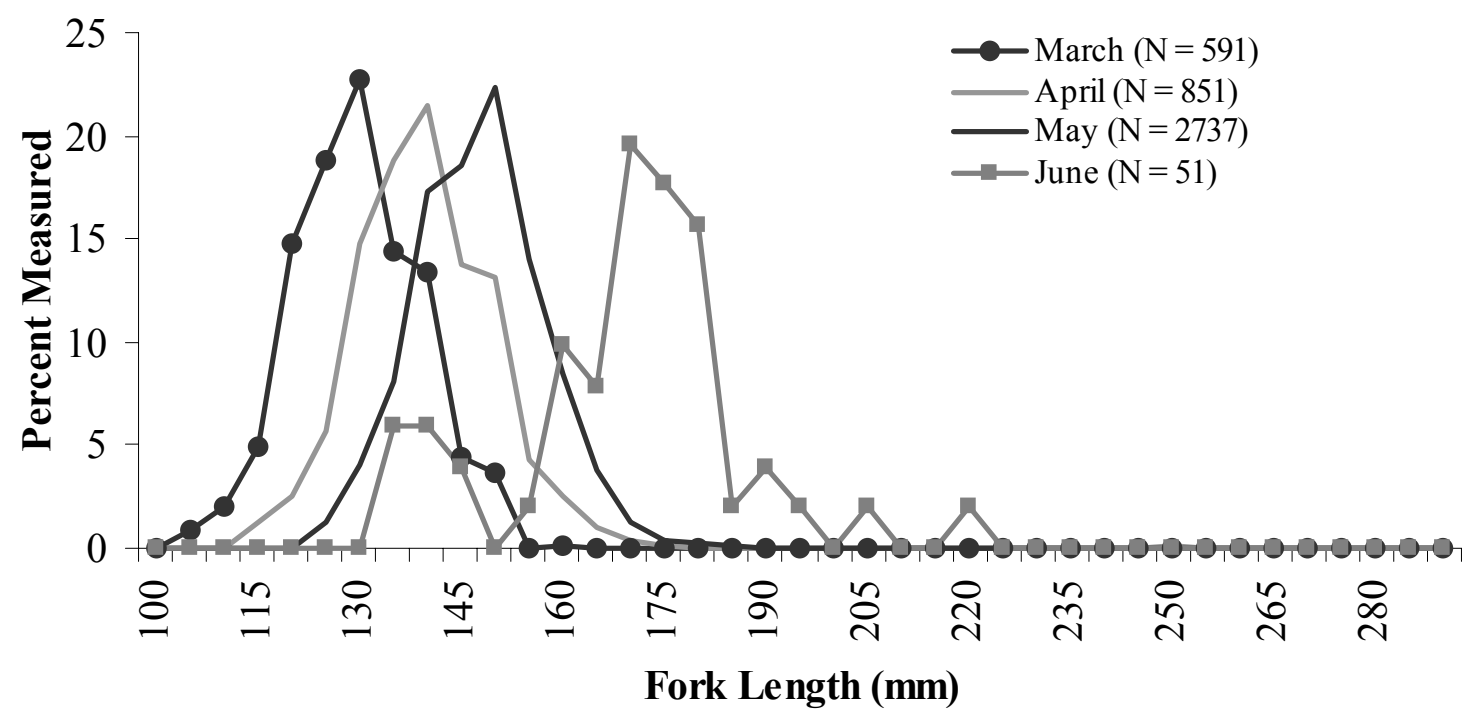

Figure 17. Length frequency distribution of hatchery and unknown coho salmon captured at RM 3.7, Umatilla River, March - June 2001. 


\section{Hatchery}

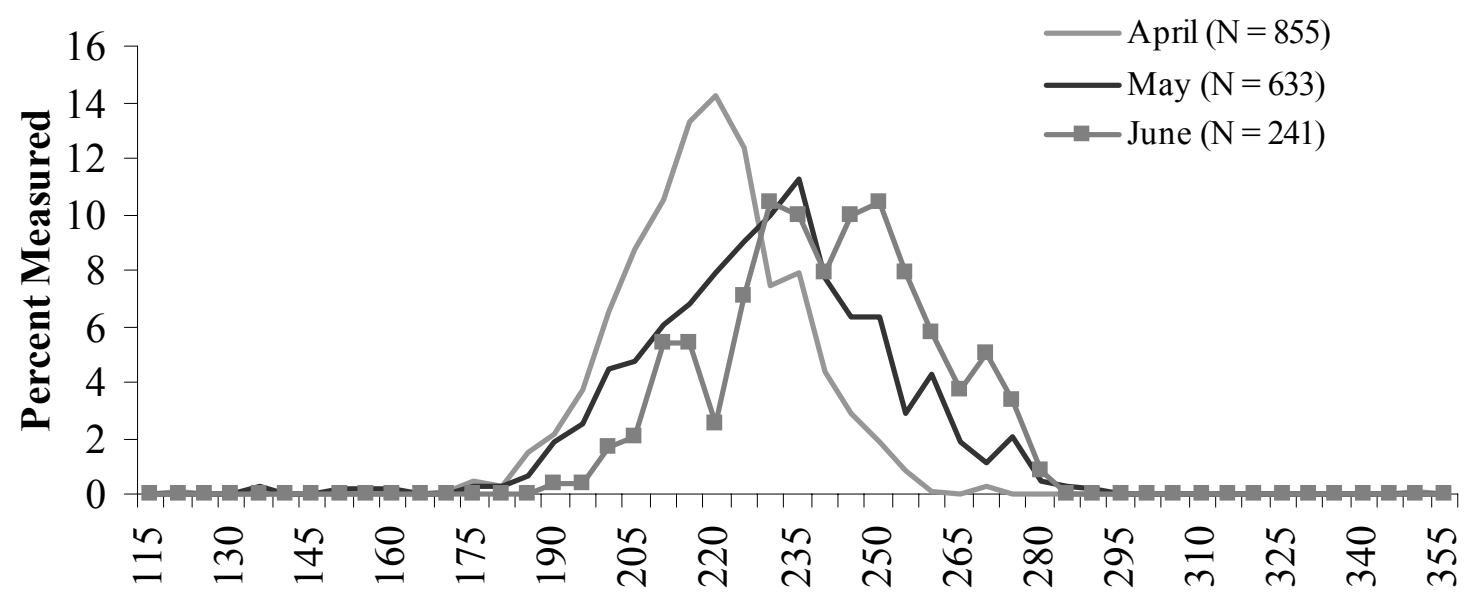

Fork Length (mm)

\section{Natural}

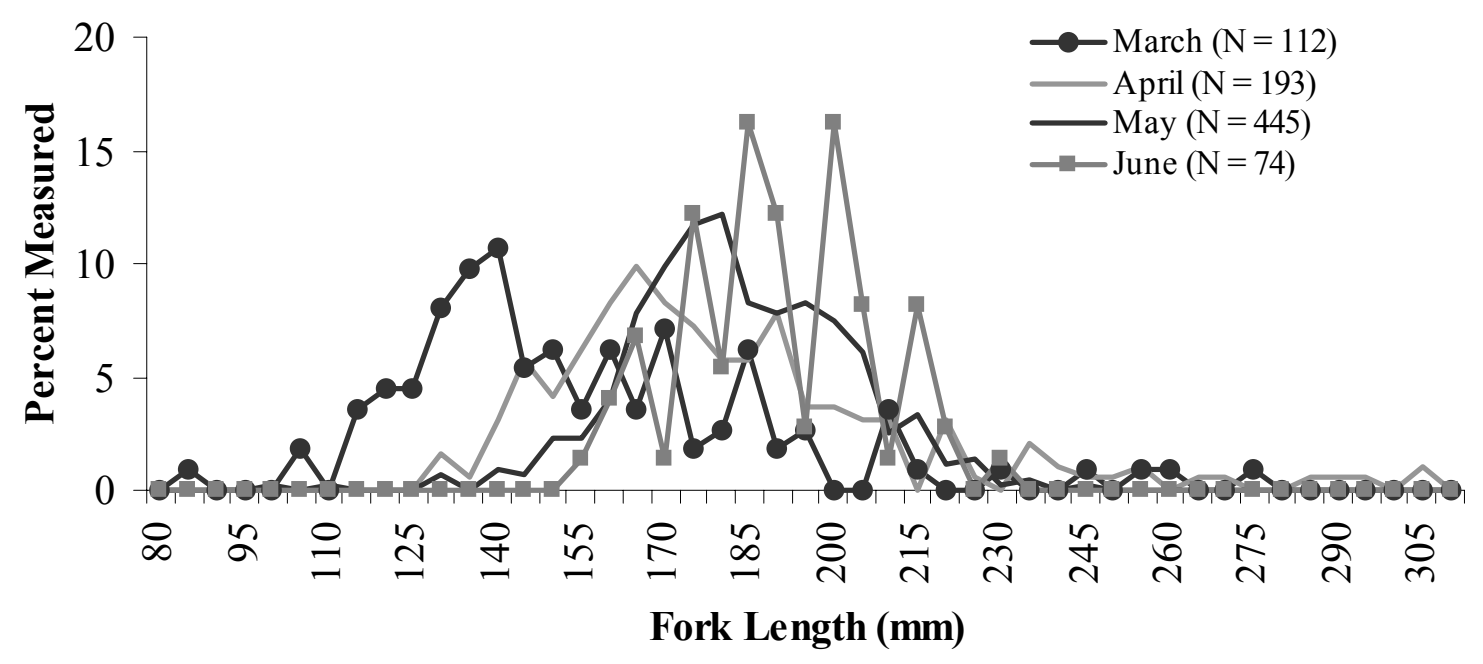

Figure 18. Length frequency distribution of hatchery and natural summer steelhead captured at RM 3.7, Umatilla River, March - June 2001. 


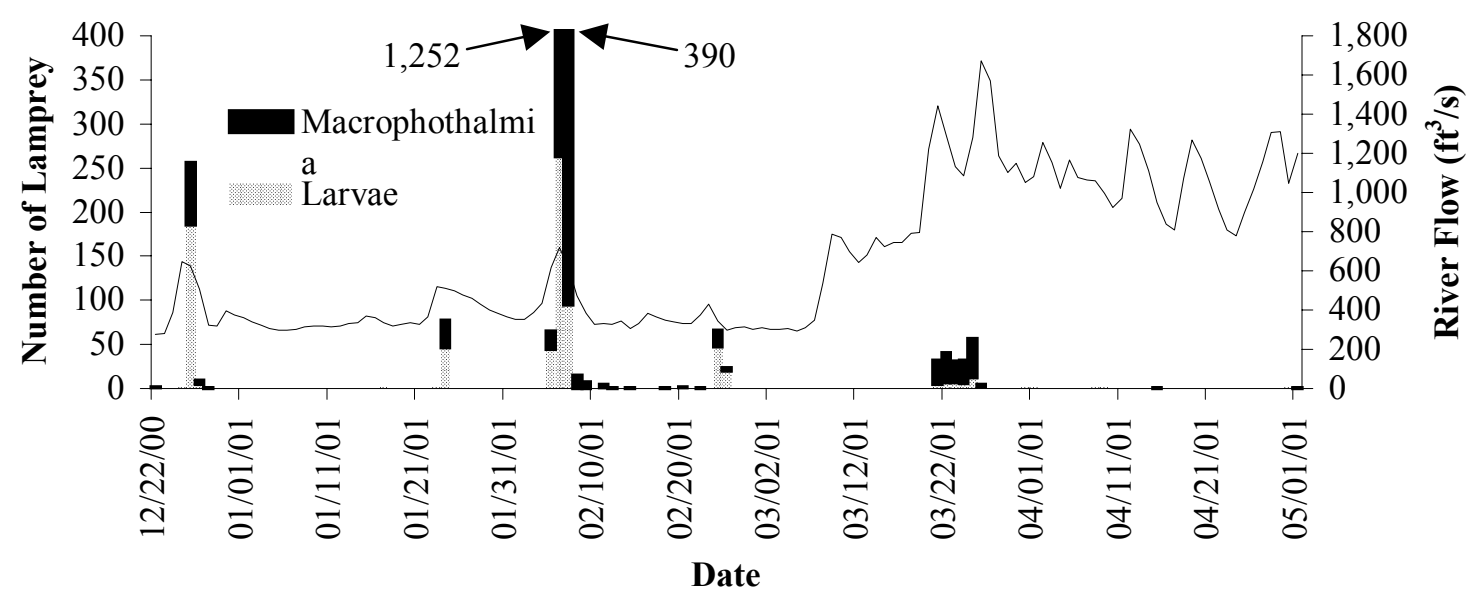

Figure 19. River flow (ft3/s) recorded at RM 2.1 and number of juvenile Pacific lamprey sampled at RM 1.2 and RM 3.7, Umatilla River, October 2000 - May 2001. 
December 2000

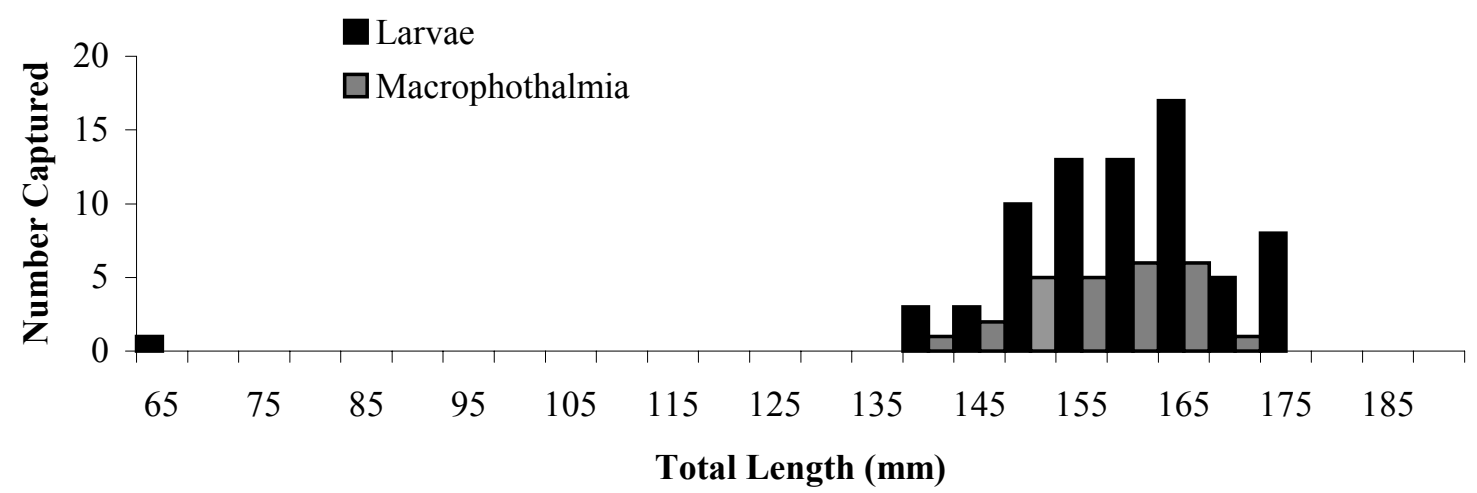

January - March 2001

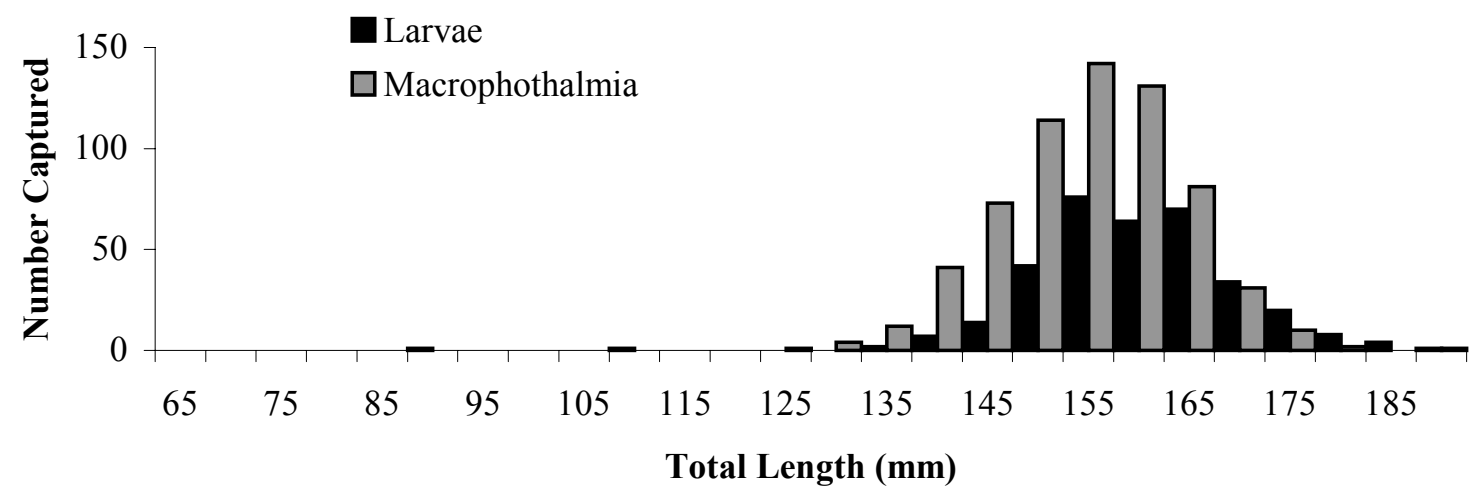

April - May 2001

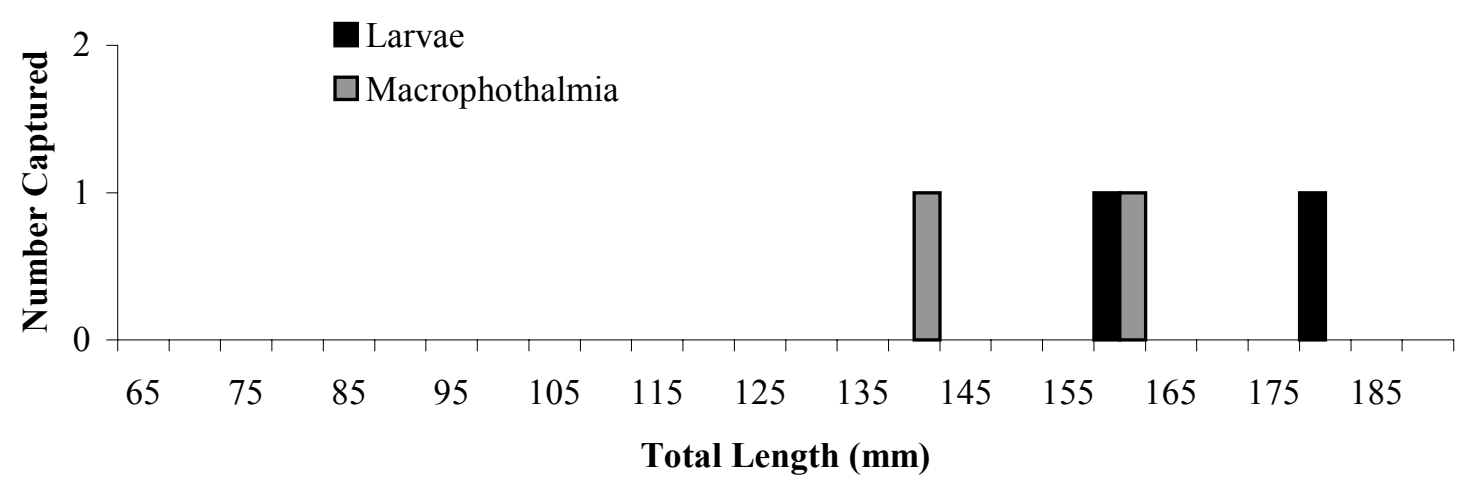

Figure 20. Length-frequency distribution by calendar quarter of juvenile Pacific lamprey sampled at RM 1.2 and RM 3.7, Umatilla River, December 2000 - May 2001. 


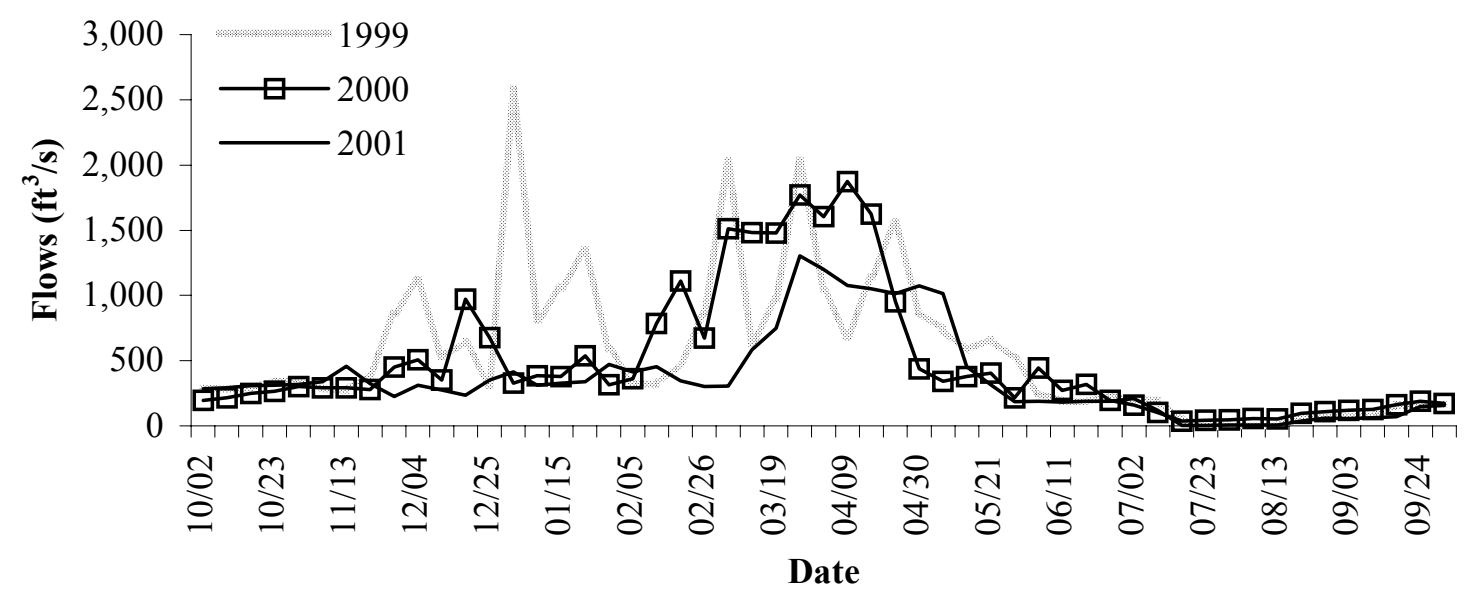

Figure 21. Average weekly river flow ( $\left.\mathrm{ft}^{3} / \mathrm{s}\right)$ at RM 2.1, Umatilla River, October - September 1998 2001.

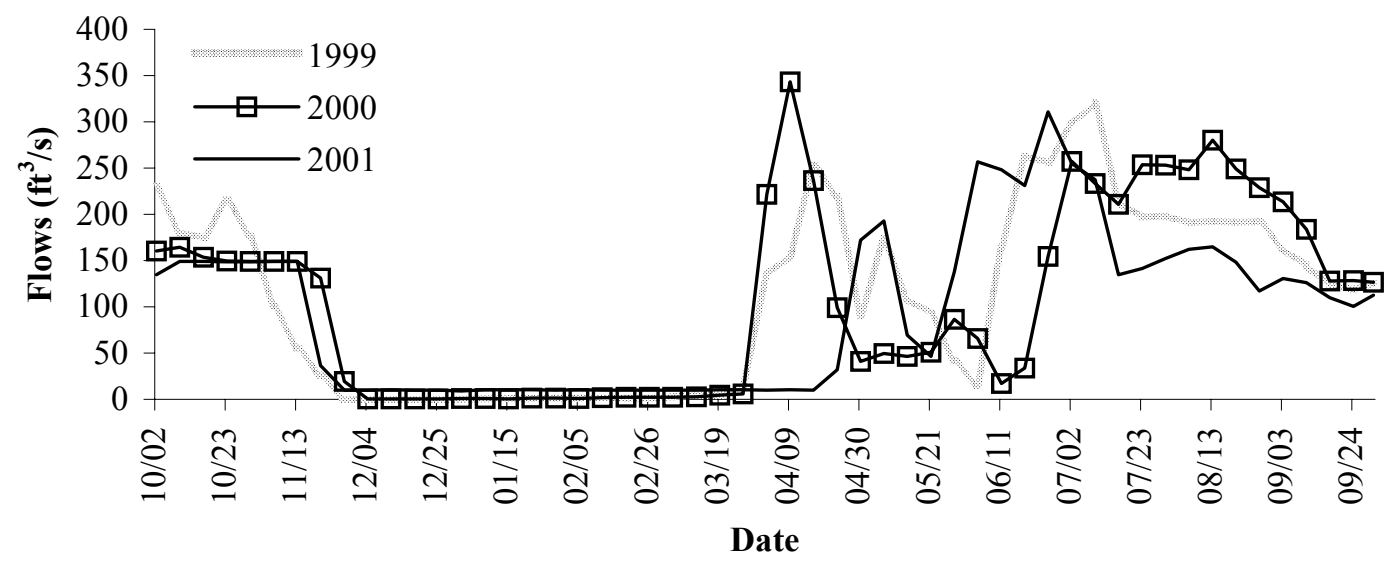

Figure 22. Average weekly release flow $\left(\mathrm{ft}^{3} / \mathrm{s}\right)$ from McKay Reservoir, October - September $1998-$ 2001. 


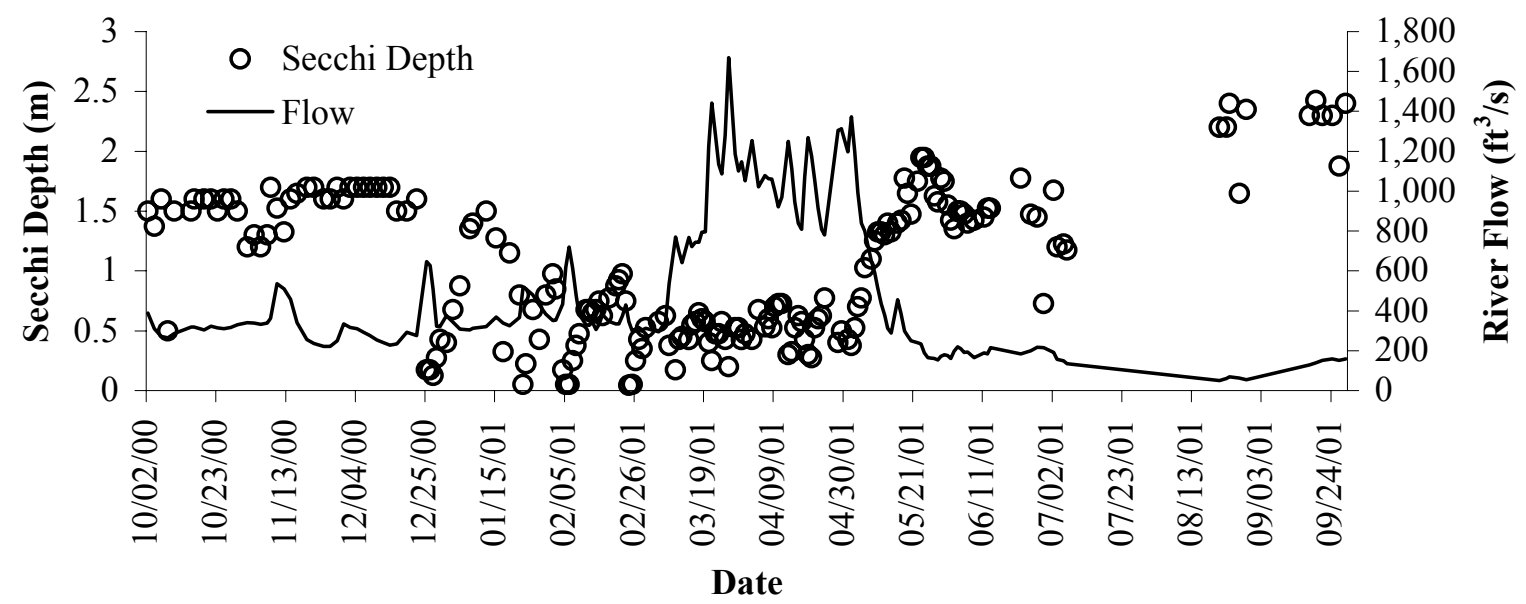

Figure 23. Mean daily secchi depth (m) and river flow $\left(\mathrm{ft}^{3} / \mathrm{s}\right)$, Umatilla River, October $2000-$ September 2001.

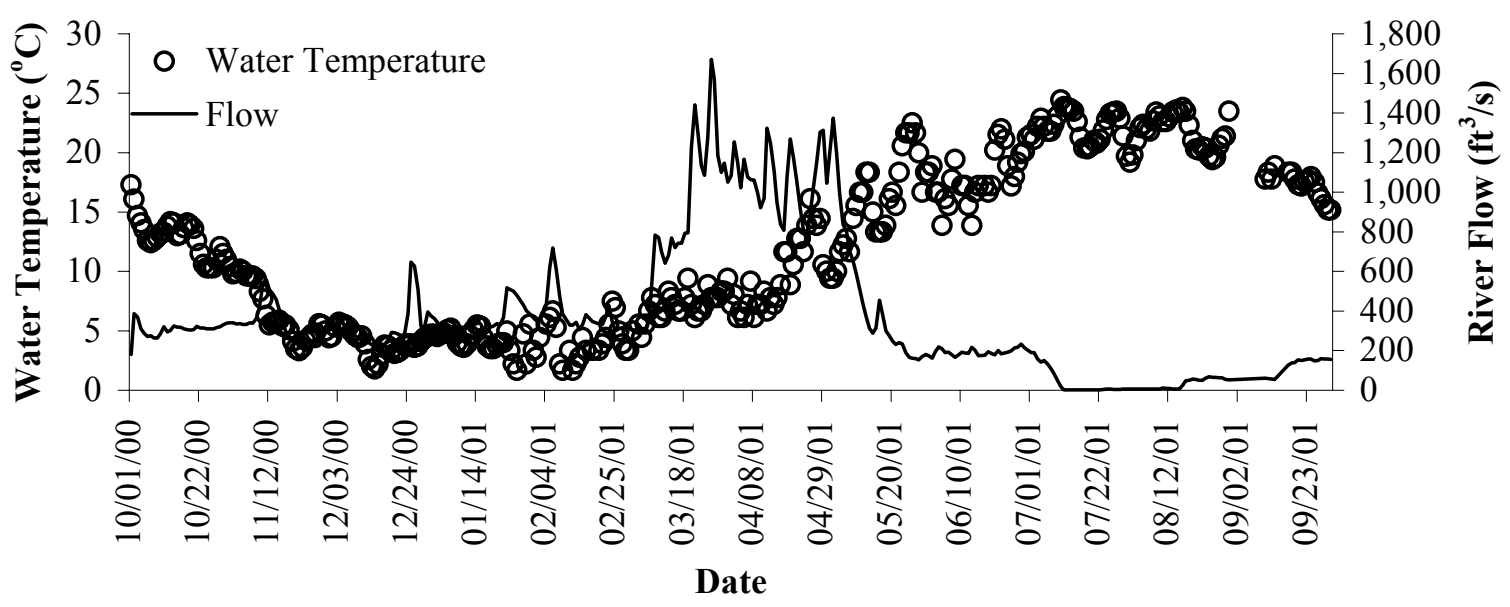

Figure 24. Mean daily water temperature $\left({ }^{\circ} \mathrm{C}\right)$ and river flow $\left(\mathrm{ft}^{3} / \mathrm{s}\right)$, Umatilla River, October $2000-$ September 2001. 


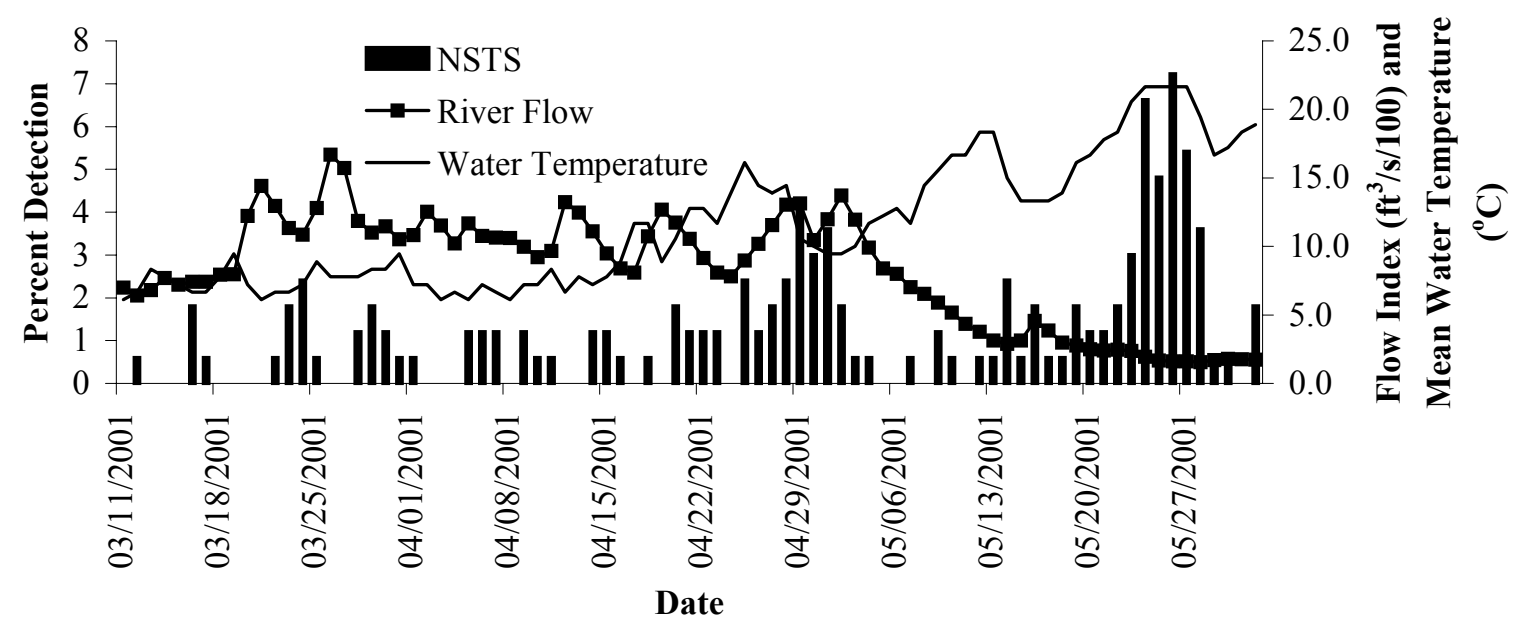

Figure 25. Daily river flow index $\left(\mathrm{ft}^{3} / \mathrm{s} / 100\right)$, mean water temperature $\left({ }^{\circ} \mathrm{C}\right)$, and percent detection of PIT-tagged natural summer steelhead (NSTS) at RM 3.7, Umatilla River, March - May 2001.

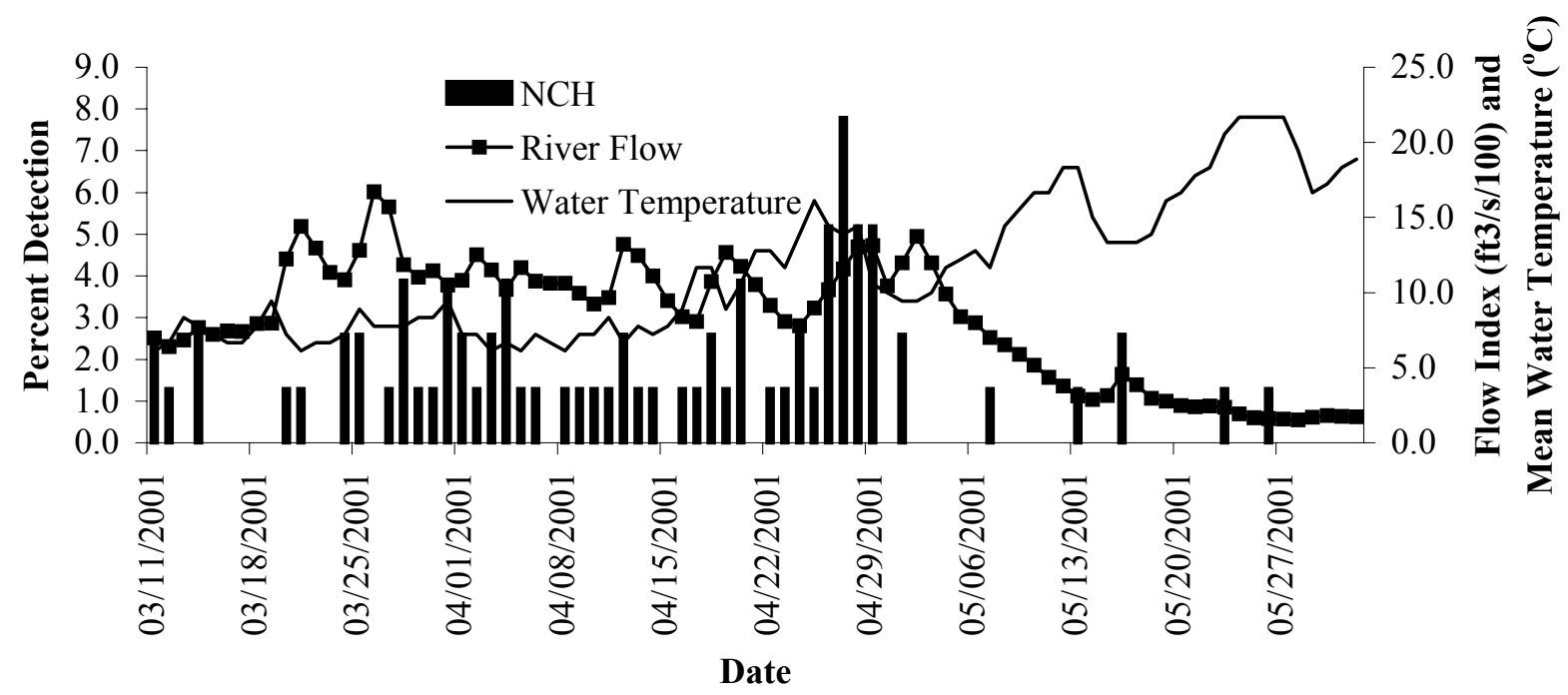

Figure 26. Daily river flow index $\left(\mathrm{ft}^{3} / \mathrm{s} / 100\right)$, mean water temperature $\left({ }^{\circ} \mathrm{C}\right)$, and percent detection of PIT tagged natural chinook salmon (NCH) at RM 3.7, Umatilla River, March - May 2001. 

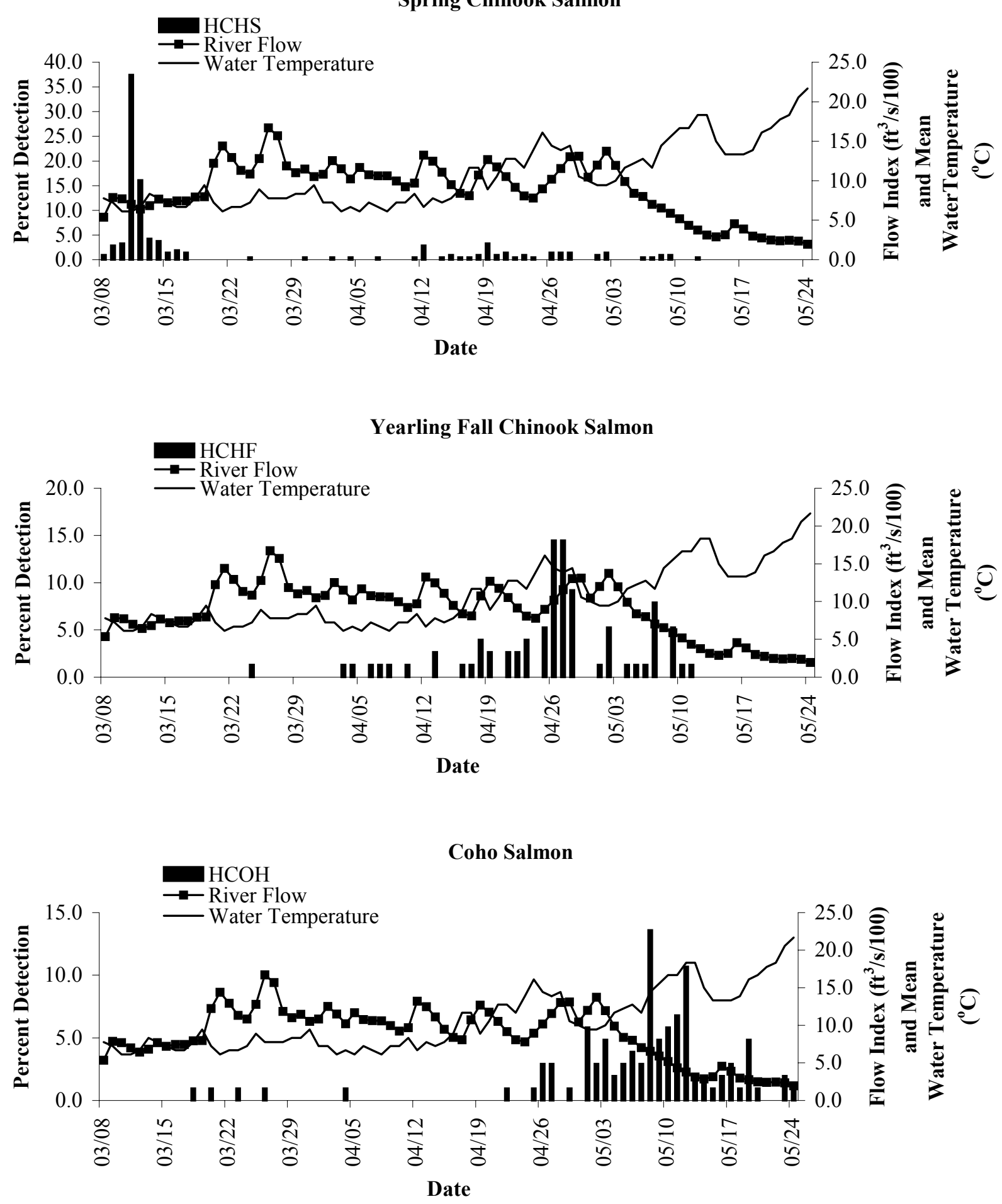

Figures 27. Daily river flow index $\left(\mathrm{ft}^{3} / \mathrm{s} / 100\right)$, mean water temperature $\left({ }^{\circ} \mathrm{C}\right)$, and percent detection of PIT tagged hatchery spring chinook (HCHS), yearling fall chinook (HCHF), and coho (HCOH) salmon at RM 3.7, Umatilla River, 2001. 


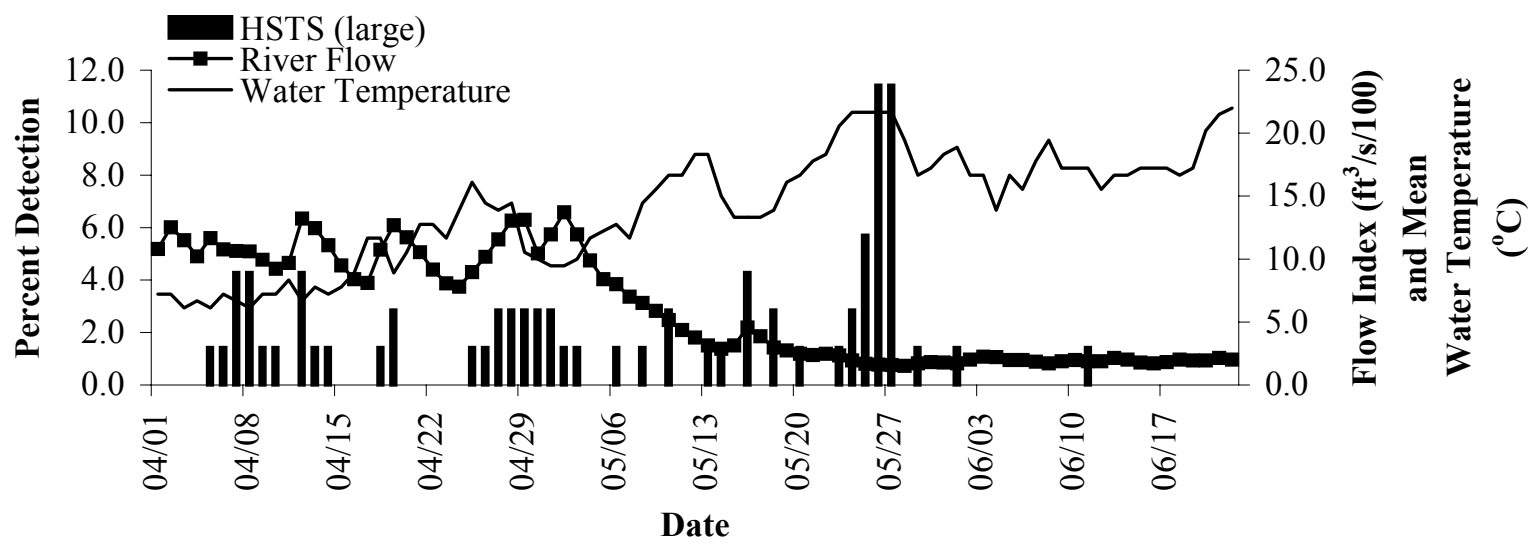

Small-grade Summer Steelhead

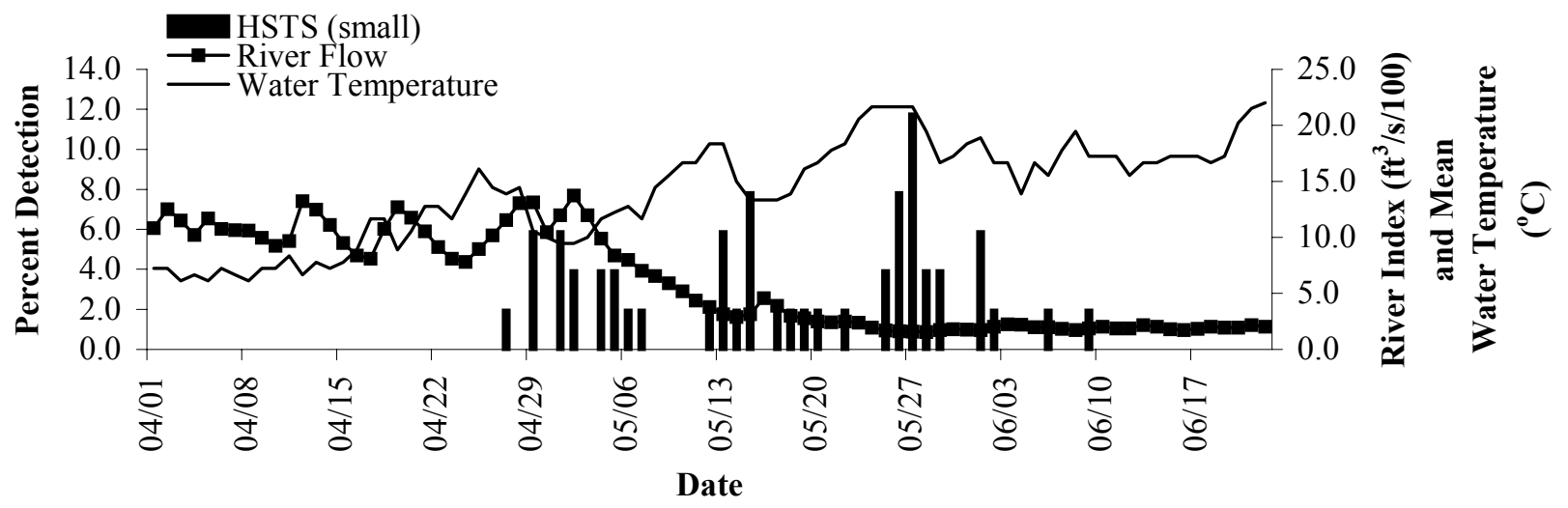

Subyearling Fall Chinook Salmon

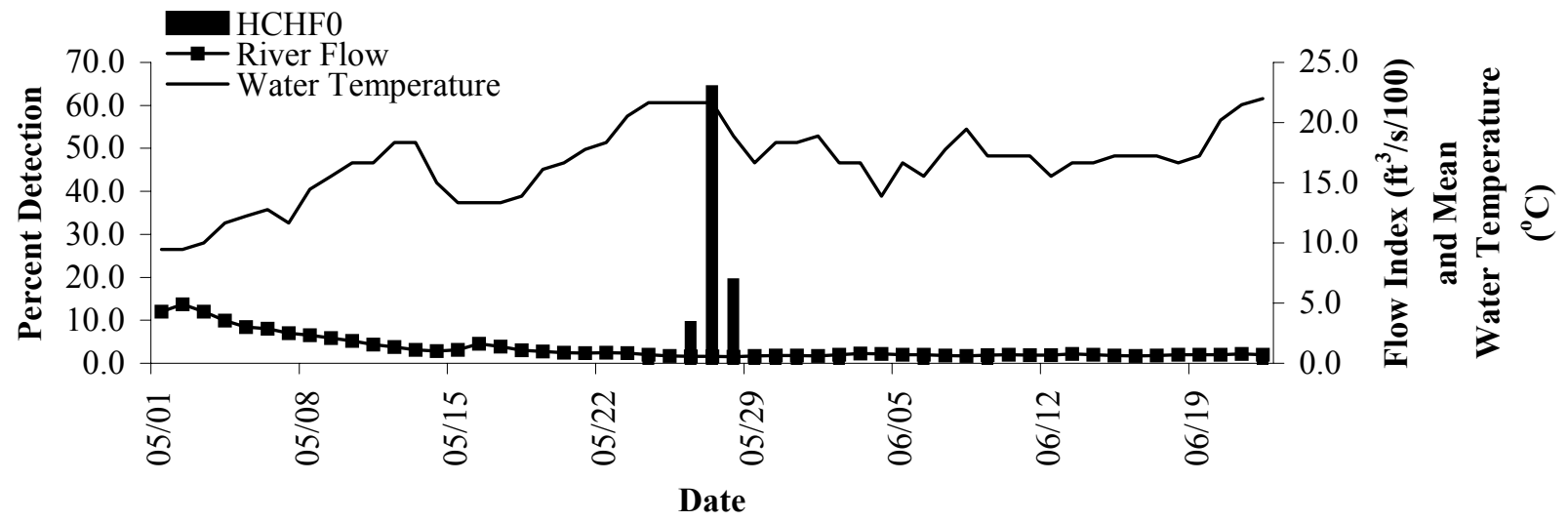

Figure 28. Daily river flow index $\left(\mathrm{ft}^{3} / \mathrm{s} / 100\right)$, mean water temperature $\left({ }^{\circ} \mathrm{C}\right)$, and percent detection of PIT tagged hatchery large and small-grade summer steelhead (HSTS) and subyearling fall chinook salmon (HCHF0) at RM 3.7, Umatilla River, 2001. 
APPENDIX A

Auxillary Information from Outmigration Studies 
Appendix Table 1. Maximum monthly fork length used to determine origin of unmarked juvenile chinook and coho salmon, Umatilla River, October 2000 - September 2001.

\begin{tabular}{lcc} 
& \multicolumn{2}{c}{ Fork length $(\mathrm{mm})$} \\
\cline { 2 - 3 } Month & Chinook salmon & Coho \\
\hline October & all sizes & all sizes \\
February & all sizes & all sizes \\
March & $\leq 110$ & $\leq 100$ \\
April & $\leq 110$ & $\leq 110$ \\
May & $\leq 120$ & $\leq 120$ \\
June & $\leq 130$ & $\leq 125$ \\
July & $\leq 140$ & $\leq 130$ \\
August & $\leq 150$ & -- \\
September & $\leq 160$ & -- \\
\hline
\end{tabular}


Appendix Table 2. Correlation of mean daily river flow $\left(\mathrm{ft}^{3} / \mathrm{s}\right)$ and capture of juvenile Pacific lamprey at RM 1.2 and 3.7, Umatilla River, December 2000 - May 2001.

\begin{tabular}{|c|c|c|c|}
\hline Life stage & $N^{a}$ & $r^{b}$ & $P_{0 s^{c}}$ \\
\hline
\end{tabular}

RM 1.2

Larvae

Macrophothalmia
14

18
0.642

0.643
0.013

$<0.001$

RM 3.7

\begin{tabular}{lccc} 
Larvae & 11 & 0.272 & 0.419 \\
Macrophothalmia & 8 & 0.032 & 0.940 \\
\hline
\end{tabular}

${ }^{a} \mathrm{~N}=$ number of observations.

${ }^{b} \mathrm{r}=$ correlation coefficient.

$c$ Probability (t-test) that the correlation coefficient is no different from zero; significant $\mathrm{P} \leq 0.05$.

Appendix Table 3. Pacific lamprey captured at RM 1.2 and RM 3.7, 1995 - 2001.

\begin{tabular}{lcccc}
\hline Year & Adult & Macrophothalmia & Larvae & Unknown juvenile \\
\hline & & & & \\
1995 & 17 & 0 & 0 & 24 \\
1996 & 12 & 0 & 0 & 214 \\
1997 & 8 & 0 & 0 & 297 \\
1998 & 1 & 103 & 465 & 0 \\
1999 & 0 & 76 & 197 & 1 \\
2000 & 1 & 133 & 363 & 0 \\
2001 & 1 & 1988 & 755 & 0 \\
\hline
\end{tabular}


Appendix Table 4. Mean length, tag loss, and handling mortality of tagged fish used in reachsurvival tests, Umatilla River, March - April 2001.

\begin{tabular}{|c|c|c|c|c|c|c|}
\hline Rearing & $\begin{array}{c}\text { Release } \\
\text { site }\end{array}$ & $\begin{array}{c}\text { Mean } \\
\text { FL }(\mathrm{SE})^{a}\end{array}$ & $\begin{array}{c}\text { Number } \\
\text { tagged }\end{array}$ & $\begin{array}{l}\text { Tag } \\
\text { loss } \\
\end{array}$ & $\begin{array}{l}\text { Percent } \\
\text { tag loss }\end{array}$ & $\begin{array}{l}\text { Tagging } \\
\text { mortality }\end{array}$ \\
\hline \multicolumn{7}{|c|}{ Summer Steelhead } \\
\hline Large grade & RM 79 & $204.2(0.5)$ & 1,171 & 74 & 6.3 & \\
\hline Large grade & RM 64.5 & $203.9(0.5)$ & 1,184 & 56 & 4.7 & $20^{b}$ \\
\hline Large grade & RM 48 & $204.5(0.6)$ & 1054 & 29 & 2.8 & \\
\hline Large grade & RM 27 & $202.7(1.0)$ & 721 & 29 & 4.0 & \\
\hline Large grade & RM 9 & $206.7(1.0)$ & 589 & 30 & 5.1 & \\
\hline Small grade & RM 64.5 & $205.8(2.0)$ & 1,466 & 57 & 3.9 & \\
\hline Small grade & RM 48 & $204.4(1.2)$ & 1,482 & 69 & 4.7 & 2 \\
\hline Small grade & RM 27 & $204.5(1.2)$ & 1,282 & 95 & 7.4 & \\
\hline Small grade & RM 9 & $202.6(1.2)$ & 1,206 & 16 & 1.3 & \\
\hline Total & & & 10,155 & 455 & & 22 \\
\hline
\end{tabular}

$a^{a}$ Fork length measured at time of tagging. Standard error of the mean is in parentheses.

$b$ Mortality caused by water flow problem not tagging. 
Appendix Table 5. PIT-tag recoveries at mainstem Columbia River Islands from hatchery summer steelhead released for reachspecific survival tests in the Umatilla River, 2001.

\begin{tabular}{|c|c|c|c|c|c|c|c|c|c|c|c|c|}
\hline \multirow[b]{2}{*}{$\begin{array}{l}\text { Release } \\
\text { site }\end{array}$} & \multirow[b]{2}{*}{$\begin{array}{c}\text { Release } \\
\text { date }\end{array}$} & \multirow[b]{2}{*}{$\begin{array}{l}\text { Number } \\
\text { released }\end{array}$} & \multicolumn{8}{|c|}{ Recovery Site $^{a}$ (date) } & \multirow[b]{2}{*}{$\begin{array}{c}\text { Total } \\
\text { recovery }\end{array}$} & \multirow[b]{2}{*}{$\begin{array}{l}\text { Percent } \\
\text { recovery }\end{array}$} \\
\hline & & & COLR & $\begin{array}{c}\text { ESANIS } \\
(12 / 01)\end{array}$ & $\begin{array}{c}\text { RICEIS } \\
(10 / 01)\end{array}$ & $\begin{array}{c}\text { LMILIS } \\
(10 / 01)\end{array}$ & $\begin{array}{c}\text { 3MILIS } \\
(1 / 02)\end{array}$ & $\begin{array}{c}\text { CRESIS } \\
(9 / 01)\end{array}$ & $\begin{array}{c}\text { FOUNDI } \\
(12 / 01) \\
\end{array}$ & $\begin{array}{c}\text { IS18 } \\
(12 / 01)\end{array}$ & & \\
\hline \multicolumn{13}{|c|}{ Large Grade Summer Steelhead } \\
\hline RM 9 & $4 / 3-5$ & 589 & 0 & 8 & 0 & 14 & 1 & 5 & 1 & 0 & 29 & 4.92 \\
\hline RM 27 & $4 / 3-5$ & 721 & 1 & 9 & 0 & 10 & 2 & 0 & 2 & 0 & 24 & 3.33 \\
\hline RM 48 & $4 / 3-5$ & 1,054 & 0 & 7 & 0 & 12 & 3 & 5 & 2 & 0 & 29 & 2.75 \\
\hline RM 64.5 & $4 / 3-5$ & 1,184 & 0 & 13 & 0 & 17 & 5 & 4 & 2 & 0 & 41 & 3.46 \\
\hline RM 79 & $4 / 3-5$ & 1,171 & 0 & 8 & 0 & 11 & 5 & 2 & 1 & 1 & 28 & 2.39 \\
\hline & & & & & & & & & & Total & 151 & 3.20 \\
\hline
\end{tabular}

Small Grade Summer Steelhead

\begin{tabular}{|c|c|c|c|c|c|c|c|c|c|c|c|c|}
\hline RM 9 & $4 / 25-26$ & 1,206 & 0 & 30 & 2 & 31 & 9 & 3 & 2 & 0 & 77 & 6.38 \\
\hline RM 27 & $4 / 25-26$ & 1,282 & 0 & 31 & 1 & 21 & 5 & 3 & 3 & 0 & 64 & 4.99 \\
\hline RM 48 & $4 / 25-26$ & 1,482 & 0 & 22 & 0 & 32 & 5 & 4 & 5 & 0 & 68 & 4.59 \\
\hline RM 64.5 & $4 / 25-26$ & 1,466 & 0 & 19 & 0 & 32 & 9 & 5 & 2 & 0 & 67 & 4.57 \\
\hline & & & & & & & & & & Total & 276 & 5.08 \\
\hline
\end{tabular}

$a$ COLR $=$ Columbia River (RM 000), ESANIS $=$ East Sand Island (RM 5), RICEIS = Rice Island (RM 21), LMILIS = Little Miller Island $($ RM 206), 3MILIS $=$ Three Mile Island $(\mathrm{RM} 256), \mathrm{CRESIS}=$ Crescent Island $(\mathrm{RM} 317)$, FOUNDI $=$ Foundation Island $(\mathrm{RM}$ 518), and IS18 = Island 18 (RM 549$)$. 
Appendix Table 6. Daily observations at RM 1.2, Umatilla River, October 2000 - March 2001.

\begin{tabular}{|c|c|c|c|c|c|c|c|c|c|c|}
\hline \multirow[b]{2}{*}{ Date } & \multirow[b]{2}{*}{ Time } & \multirow[b]{2}{*}{ Debris $^{a}$} & \multirow{2}{*}{$\begin{array}{l}\text { Cone } \\
\mathrm{RPM}^{b}\end{array}$} & \multirow{2}{*}{$\begin{array}{c}\text { River } \\
\text { Gauge (ft.) }\end{array}$} & \multicolumn{2}{|c|}{ Secchi Depth } & \multicolumn{2}{|c|}{ Water Temp. $\left({ }^{\circ} \mathrm{F}\right)$} & \multicolumn{2}{|c|}{ Air Temp. $\left({ }^{\circ} \mathrm{F}\right)$} \\
\hline & & & & & Down & $\mathrm{Up}$ & Min. & Max. & Min. & Max. \\
\hline $10 / 2$ & $15: 21$ & -- & 2.25 & 2.75 & -- & -- & -- & -- & -- & -- \\
\hline $10 / 4$ & $12: 30$ & M & 3.00 & 2.58 & 1.40 & 1.35 & -- & -- & -- & -- \\
\hline $10 / 6$ & $14: 00$ & M & 2.75 & 2.58 & 1.60 & * & 51 & 59 & 52 & 60 \\
\hline $10 / 8$ & $17: 10$ & $\mathrm{M}$ & 3.00 & 2.58 & 0.50 & $*$ & 56 & 50 & 32 & 72 \\
\hline $10 / 2$ & $18: 20$ & $\mathrm{H}$ & 3.00 & 2.58 & 1.50 & $*$ & 54 & 60 & 48 & 64 \\
\hline $10 / 10$ & $8: 30$ & M & 2.75 & 2.58 & 1.50 & * & 52 & 61 & 42 & 64 \\
\hline $10 / 15$ & $17: 20$ & $\mathrm{H}$ & 3.00 & 2.61 & 1.50 & * & 54 & 58 & 36 & 70 \\
\hline $10 / 16$ & $16: 15$ & $\mathrm{M}$ & 3.50 & 2.61 & 1.60 & $*$ & 54 & 59 & 44 & 71 \\
\hline $10 / 19$ & $14: 45$ & M & 3.25 & 2.58 & 1.60 & * & 55 & 59 & 41 & 71 \\
\hline $10 / 21$ & $17: 20$ & M & 3.00 & 2.61 & 1.60 & * & 54 & 58 & 44 & 64 \\
\hline $10 / 23$ & $14: 40$ & M & 2.50 & 2.61 & 1.50 & * & 50 & 54 & 30 & 57 \\
\hline $10 / 25$ & 8:00 & M & 3.25 & 2.61 & 1.60 & * & 48 & 52 & 30 & 54 \\
\hline $10 / 27$ & 8:00 & $\mathrm{M}$ & 3.00 & 2.61 & 1.60 & $*$ & 48 & 50 & 40 & 56 \\
\hline $10 / 29$ & 8:00 & $\mathrm{H}$ & 2.25 & 2.67 & 1.50 & * & 52 & 56 & 38 & 62 \\
\hline $11 / 1$ & $9: 30$ & $\mathrm{H}$ & 2.75 & 2.61 & 1.20 & * & 50 & 52 & 32 & 58 \\
\hline $11 / 3$ & $15: 00$ & $\mathrm{M}$ & 3.00 & 2.33 & 1.30 & $*$ & 48 & 53 & 33 & 60 \\
\hline $11 / 5$ & $13: 00$ & $\mathrm{M}$ & 2.75 & 2.79 & 1.20 & $*$ & 51 & 52 & 32 & 58 \\
\hline $11 / 7$ & $14: 45$ & M & 2.75 & 2.83 & 1.30 & * & 53 & 53 & 31 & 57 \\
\hline $11 / 8$ & $15: 15$ & $\mathrm{M}$ & 2.75 & 2.83 & 1.70 & $*$ & 47 & 53 & 41 & 53 \\
\hline $11 / 10$ & $11: 50$ & $\mathrm{M}$ & 2.00 & 2.75 & 1.55 & 1.50 & 46 & 50 & 32 & 44 \\
\hline $11 / 11$ & $15: 20$ & $\mathrm{~L}$ & -- & 3.01 & -- & -- & -- & -- & -- & -- \\
\hline $11 / 12$ & $16: 00$ & M & 2.75 & 3.01 & 1.35 & 1.30 & 42 & 46 & 20 & 40 \\
\hline $11 / 14$ & 8:00 & $\mathrm{M}$ & 2.25 & 2.75 & 1.60 & $*$ & 40 & 45 & 28 & 42 \\
\hline $11 / 16$ & $15: 45$ & $\mathrm{M}$ & 3.25 & 2.83 & 1.65 & $*$ & 40 & 42 & 22 & 42 \\
\hline $11 / 19$ & $13: 45$ & $\mathrm{M}$ & 1.75 & 2.70 & 1.70 & $*$ & 39 & 43 & 21 & 38 \\
\hline $11 / 21$ & $14: 00$ & $\mathrm{~L}$ & 2.00 & 2.70 & 1.70 & * & 42 & 43 & 21 & 34 \\
\hline $11 / 24$ & $16: 00$ & $\mathrm{M}$ & 1.75 & 2.50 & 1.60 & $*$ & 36 & 42 & -- & -- \\
\hline $11 / 26$ & $13: 30$ & $\mathrm{~L}$ & 2.01 & 2.50 & 1.60 & $*$ & 37 & 42 & 28 & 37 \\
\hline $11 / 28$ & 8:00 & $\mathrm{M}$ & 2.75 & 2.67 & 1.70 & $*$ & 40 & 44 & 23 & 50 \\
\hline $11 / 30$ & $8: 00$ & M & 2.50 & 2.67 & 1.60 & $*$ & 40 & 44 & 26 & 40 \\
\hline $12 / 2$ & $12: 20$ & $\mathrm{M}$ & 3.25 & 2.79 & 1.70 & $*$ & 38 & 43 & 28 & 41 \\
\hline $12 / 4$ & $13: 45$ & M & 3.00 & 2.79 & 1.70 & $*$ & 40 & 45 & 30 & 41 \\
\hline
\end{tabular}


Appendix Table 6. Continued.

\begin{tabular}{|c|c|c|c|c|c|c|c|c|c|c|}
\hline \multirow[b]{2}{*}{ Date } & \multirow[b]{2}{*}{ Time } & \multirow[b]{2}{*}{ Debris $^{a}$} & \multirow{2}{*}{$\begin{array}{l}\text { Cone } \\
\mathrm{RPM}^{b}\end{array}$} & \multirow{2}{*}{$\begin{array}{c}\text { River } \\
\text { Gauge (ft.) }\end{array}$} & \multicolumn{2}{|c|}{ Secchi Depth $^{c}$} & \multicolumn{2}{|c|}{ Water Temp. $\left({ }^{\circ} \mathrm{F}\right)$} & \multicolumn{2}{|c|}{ Air Temp. $\left({ }^{\circ} \mathrm{F}\right)$} \\
\hline & & & & & Down & Up & Min. & Max. & Min. & Max. \\
\hline $12 / 6$ & $14: 15$ & $\mathrm{M}$ & 3.00 & 2.75 & 1.70 & $*$ & 41 & 44 & 34 & 42 \\
\hline $12 / 8$ & $16: 10$ & $\mathrm{~L}$ & 3.25 & 2.75 & 1.70 & $*$ & 41 & 42 & 30 & 35 \\
\hline $12 / 10$ & $14: 30$ & $\mathrm{~L}$ & 2.25 & 2.75 & 1.70 & $*$ & 41 & 42 & 24 & 41 \\
\hline $12 / 12$ & $15: 45$ & M & 2.25 & 2.67 & 1.70 & $*$ & 38 & 42 & 15 & 38 \\
\hline $12 / 14$ & $13: 45$ & M & 1.75 & 2.71 & 1.70 & $*$ & 34 & 37 & 22 & 28 \\
\hline $12 / 16$ & $8: 00$ & M & 1.75 & 2.50 & 1.50 & $*$ & 34 & 38 & 21 & 44 \\
\hline $12 / 19$ & $10: 15$ & $\mathrm{H}$ & 2.75 & 2.58 & 1.50 & $*$ & -- & -- & 21 & 46 \\
\hline $12 / 22$ & $15: 00$ & $\mathrm{H}$ & 2.00 & 2.58 & 1.60 & $*$ & 42 & -- & 26 & 36 \\
\hline $12 / 25$ & $16: 00$ & M & 4.00 & 3.00 & 0.20 & 0.15 & 40 & -- & 30 & 36 \\
\hline $12 / 26$ & $8: 00$ & M & 3.75 & 3.08 & 0.20 & 0.15 & 40 & -- & 31 & 34 \\
\hline $12 / 27$ & 8:00 & $\mathrm{L}$ & 3.25 & 3.00 & 0.15 & 0.10 & 41 & 49 & 31 & 38 \\
\hline $12 / 28$ & $9: 00$ & -- & 3.00 & 2.67 & 0.30 & 0.25 & 39 & 40 & 31 & 41 \\
\hline $12 / 29$ & $15: 30$ & $\mathrm{~L}$ & 3.00 & 2.88 & 0.45 & 0.40 & 38 & 40 & 32 & 34 \\
\hline $12 / 31$ & $16: 00$ & $\mathrm{~L}$ & 3.00 & 2.83 & 0.40 & 0.40 & 41 & 42 & 33 & 42 \\
\hline $1 / 2$ & $14: 45$ & $\mathrm{~L}$ & 3.00 & 2.80 & 0.70 & 0.65 & 39 & 41 & 29 & 39 \\
\hline $1 / 4$ & $14: 10$ & $\mathrm{~L}$ & 3.00 & 2.75 & 0.90 & 0.85 & 41 & 42 & 29 & 42 \\
\hline $1 / 7$ & $9: 40$ & $\mathrm{~L}$ & 3.00 & 2.58 & 1.35 & $*$ & 40 & 42 & 24 & 56 \\
\hline $1 / 8$ & $9: 00$ & $\mathrm{~L}$ & 3.00 & 3.67 & 1.40 & $*$ & 40 & 41 & 27 & 36 \\
\hline $1 / 12$ & $9: 20$ & M & 3.00 & 3.67 & 1.50 & $*$ & 40 & 42 & 23 & 38 \\
\hline $1 / 15$ & $16: 20$ & M & 2.75 & 2.70 & 1.30 & 1.25 & 40 & 42 & 33 & 42 \\
\hline $1 / 17$ & $16: 30$ & $\mathrm{~L}$ & 3.50 & 2.83 & 0.35 & 0.30 & 39 & 42 & 26 & 35 \\
\hline $1 / 19$ & $15: 30$ & $\mathrm{~L}$ & 3.50 & 2.83 & 1.20 & 1.10 & 38 & 38 & 30 & 36 \\
\hline $1 / 22$ & $14: 15$ & $\mathrm{M}$ & 3.25 & 2.88 & 0.80 & 0.80 & 41 & 42 & 28 & 40 \\
\hline $1 / 23$ & $14: 30$ & $\mathrm{M}$ & 4.00 & 3.00 & 0.05 & 0.05 & 41 & 41 & 33 & 38 \\
\hline $1 / 24$ & $8: 00$ & M & 3.50 & 3.00 & 0.25 & 0.20 & 40 & 41 & 28 & 37 \\
\hline $1 / 26$ & $13: 55$ & $\mathrm{~L}$ & 3.00 & 2.92 & 0.70 & 0.65 & 40 & 41 & 25 & 40 \\
\hline $1 / 28$ & $11: 00$ & M & 2.75 & 2.92 & 0.45 & 0.40 & 40 & 41 & 32 & 35 \\
\hline $1 / 30$ & $15: 45$ & $\mathrm{~L}$ & 2.75 & 2.83 & 0.85 & 0.75 & 42 & 42 & 26 & 48 \\
\hline $2 / 1$ & $14: 10$ & $\mathrm{~L}$ & 2.75 & 2.83 & 1.00 & 0.95 & 40 & 41 & 26 & 53 \\
\hline $2 / 2$ & $15: 45$ & $\mathrm{~L}$ & 2.90 & 2.83 & 0.90 & 0.80 & 41 & 44 & 35 & 53 \\
\hline $2 / 4$ & $8: 00$ & $\mathrm{~L}$ & 3.25 & 2.92 & 0.20 & 0.15 & 43 & 46 & 31 & 53 \\
\hline $2 / 5$ & $10: 50$ & $\mathrm{M}$ & 4.50 & 3.05 & 0.05 & 0.05 & 42 & 45 & 40 & 48 \\
\hline $2 / 6$ & $14: 20$ & $\mathrm{M}$ & 3.75 & 3.08 & 0.05 & 0.05 & 42 & 46 & 28 & 50 \\
\hline $2 / 7$ & $14: 00$ & M & 4.25 & 2.95 & 0.30 & 0.20 & 40 & 43 & 19 & 40 \\
\hline $2 / 8$ & $10: 15$ & $\mathrm{~L}$ & 3.50 & 2.92 & 0.35 & 0.40 & 39 & 43 & 22 & 42 \\
\hline $2 / 9$ & $10: 00$ & $\mathrm{~L}$ & 3.25 & 2.87 & 0.50 & 0.45 & 38 & 41 & 30 & 40 \\
\hline
\end{tabular}


Appendix Table 6. Continued.

\begin{tabular}{|c|c|c|c|c|c|c|c|c|c|c|}
\hline \multirow[b]{2}{*}{ Date } & \multirow[b]{2}{*}{ Time } & \multirow[b]{2}{*}{ Debris $^{a}$} & \multirow{2}{*}{$\begin{array}{l}\text { Cone } \\
\mathrm{RPM}^{b}\end{array}$} & \multirow{2}{*}{$\begin{array}{c}\text { River } \\
\text { Gauge (ft.) }\end{array}$} & \multicolumn{2}{|c|}{ Secchi Depth ${ }^{c}$} & \multicolumn{2}{|c|}{ Water Temp. $\left({ }^{\circ} \mathrm{F}\right)$} & \multicolumn{2}{|c|}{ Air Temp. $\left({ }^{\circ} \mathrm{F}\right)$} \\
\hline & & & & & Down & $\mathrm{Up}$ & Min. & Max. & Min. & Max. \\
\hline $2 / 11$ & 16:00 & $M$ & 3.25 & 2.75 & 0.70 & 0.65 & 40 & 42 & 24 & 42 \\
\hline $2 / 12$ & 11:00 & $\mathrm{L}$ & 3.50 & 2.79 & 0.70 & 0.65 & 38 & 40 & 21 & 38 \\
\hline $2 / 13$ & $9: 15$ & $\mathrm{~L}$ & 3.25 & 2.83 & 0.70 & 0.60 & 38 & 41 & 25 & 46 \\
\hline $2 / 14$ & $9: 30$ & $\mathrm{~L}$ & 3.30 & 2.79 & 0.65 & 0.70 & 38 & 41 & 23 & 45 \\
\hline $2 / 15$ & 10:05 & $\mathrm{L}$ & 3.20 & 2.79 & 0.80 & 0.70 & 38 & 43 & 37 & 53 \\
\hline $2 / 16$ & $8: 00$ & M & 3.15 & 2.10 & 0.60 & 0.65 & 40 & 42 & 30 & 46 \\
\hline $2 / 18$ & $16: 15$ & $\mathrm{H}$ & 3.50 & 2.00 & 0.80 & 0.75 & 39 & 42 & 26 & 48 \\
\hline $2 / 20$ & $13: 30$ & M & 3.75 & 2.95 & 0.90 & 0.85 & 40 & 43 & 27 & 47 \\
\hline $2 / 21$ & 8:00 & M & 3.30 & 2.10 & 0.90 & 0.95 & 41 & 43 & 30 & 51 \\
\hline $2 / 22$ & $10: 35$ & M & 3.10 & 2.11 & 1.00 & 0.95 & 42 & 44 & 33 & 47 \\
\hline $2 / 23$ & $14: 15$ & $\mathrm{H}$ & 3.40 & 3.00 & 0.80 & 0.70 & 43 & 46 & 38 & 54 \\
\hline $2 / 24$ & $12: 20$ & M & 3.45 & 2.10 & 0.04 & 0.05 & 44 & 47 & 27 & 56 \\
\hline $2 / 25$ & $10: 15$ & M & 3.30 & 2.80 & 0.05 & 0.05 & 43 & 46 & 25 & 52 \\
\hline $2 / 26$ & $15: 45$ & M & 3.35 & 2.80 & 0.25 & 0.25 & 43 & 46 & 22 & 55 \\
\hline $2 / 27$ & $13: 45$ & $\mathrm{~L}$ & 2.80 & 2.80 & 0.40 & 0.45 & 43 & 46 & 19 & 50 \\
\hline $2 / 28$ & 8:00 & M & 3.50 & 2.75 & 0.35 & 0.35 & 40 & 46 & 19 & 52 \\
\hline $3 / 1$ & $16: 15$ & M & 3.10 & 2.75 & 0.50 & 0.55 & 40 & 44 & 23 & 51 \\
\hline $3 / 5$ & $11: 15$ & $\mathrm{M}$ & 2.70 & 2.75 & 0.60 & 0.55 & 42 & 47 & 23 & 54 \\
\hline $3 / 7$ & 10:00 & $\mathrm{M}$ & 2.75 & 2.85 & 0.65 & 0.60 & 43 & 49 & 28 & 61 \\
\hline $3 / 8$ & $15: 30$ & $\mathrm{M}$ & -- & 3.10 & 0.40 & 0.35 & 46 & 51 & 37 & 63 \\
\hline
\end{tabular}


Appendix Table 7. Daily observations at the West Extension Canal sampling facility (RM 3.7), 9 March - 28 September 2001.

\begin{tabular}{|c|c|c|c|c|c|c|c|c|c|c|c|c|c|c|c|c|}
\hline \multirow[b]{2}{*}{ Date } & \multirow[b]{2}{*}{ Time } & \multirow[b]{2}{*}{ Debris $^{a}$} & \multirow{2}{*}{$\begin{array}{c}\text { River } \\
\text { Gauge (ft.) }\end{array}$} & \multirow{2}{*}{$\begin{array}{c}\text { Canal } \\
\text { Height (ft.) }\end{array}$} & \multicolumn{2}{|c|}{ Water Temp. $\left({ }^{\circ} \mathrm{F}\right)$} & \multicolumn{2}{|c|}{ Air Temp. $\left({ }^{\circ} \mathrm{F}\right)$} & \multicolumn{3}{|c|}{ Pumpback Operations $^{b}$} & \multirow{2}{*}{$\begin{array}{c}\text { River-return } \\
\text { Pipe Opening }\end{array}$} & \multicolumn{3}{|c|}{ Headgate Openings ${ }^{c}$} & \multirow{2}{*}{$\begin{array}{c}\text { Phase I } \\
\text { Exchange }\end{array}$} \\
\hline & & & & & Min. & Max. & Min. & Max. & $\mathrm{P} 1$ & $\mathrm{P} 2$ & P3 & & $\mathrm{S}$ & $\mathrm{M}$ & $\mathrm{N}$ & \\
\hline $3 / 9$ & $15: 35$ & $\mathrm{~L}$ & 404.40 & 404.40 & 48 & 50 & 30 & 59 & OFF & OFF & OFF & 7" & 12.25 & 12.50 & 0.00 & None \\
\hline $3 / 10$ & $9: 10$ & $\mathrm{~L}$ & 404.80 & 404.35 & 44 & 46 & 29 & 51 & OFF & OFF & OFF & $5^{\prime \prime}$ & 12.25 & 12.50 & 0.00 & None \\
\hline $3 / 11$ & $9: 15$ & $\mathrm{~L}$ & 404.30 & 404.30 & 43 & 46 & 28 & 62 & OFF & OFF & OFF & $7 "$ & 12.00 & 12.50 & 0.00 & None \\
\hline $3 / 11$ & $16: 30$ & $\mathrm{~L}$ & 404.70 & 404.20 & 44 & 47 & 37 & 58 & OFF & OFF & OFF & $7 "$ & 11.00 & 10.75 & 0.00 & None \\
\hline $3 / 12$ & $8: 45$ & $\mathrm{~L}$ & 404.70 & 404.15 & 47 & 49 & 40 & 62 & OFF & OFF & OFF & $7 "$ & 11.00 & 10.75 & 0.00 & None \\
\hline $3 / 12$ & $19: 15$ & $\mathrm{~L}$ & 404.70 & 404.15 & 44 & 47 & 37 & 58 & OFF & OFF & OFF & $7 "$ & 11.00 & 10.75 & 0.00 & None \\
\hline $3 / 14$ & $12: 30$ & $\mathrm{~L}$ & 404.75 & 404.25 & 49 & 50 & 37 & 64 & OFF & OFF & OFF & $7 "$ & 11.00 & 10.75 & 0.00 & None \\
\hline $3 / 15$ & $12: 35$ & $\mathrm{~L}$ & 404.70 & 404.20 & 46 & 50 & 34 & 58 & OFF & OFF & OFF & $7 "$ & 11.00 & 10.75 & 0.00 & None \\
\hline $3 / 16$ & $11: 35$ & $\mathrm{~L}$ & 404.65 & 404.20 & 44 & 48 & 32 & 49 & OFF & OFF & OFF & $7 "$ & 11.00 & 10.75 & 0.00 & None \\
\hline $3 / 17$ & $12: 40$ & $\mathrm{~L}$ & 404.70 & 404.30 & 45 & 48 & 36 & 51 & OFF & OFF & OFF & $7 "$ & 11.00 & 10.75 & 0.00 & None \\
\hline $3 / 18$ & $9: 00$ & $\mathrm{~L}$ & 404.75 & 404.30 & 47 & 49 & 46 & 56 & OFF & OFF & OFF & $7 "$ & 10.00 & 10.25 & 0.00 & None \\
\hline $3 / 18$ & $14: 00$ & $\mathrm{~L}$ & 404.75 & 404.20 & -- & -- & -- & -- & -- & -- & -- & -- & -- & -- & -- & None \\
\hline $3 / 19$ & $9: 15$ & $\mathrm{~L}$ & 404.70 & 404.20 & 48 & 50 & 47 & 57 & OFF & OFF & OFF & $7 "$ & 10.00 & 10.25 & 0.00 & None \\
\hline $3 / 20$ & $9: 15$ & $\mathrm{~L}$ & 404.90 & 404.40 & 49 & 52 & 31 & 59 & OFF & OFF & OFF & 7" & 8.75 & 9.75 & 0.00 & None \\
\hline $3 / 20$ & $12: 13$ & $\mathrm{~L}$ & 404.90 & 404.30 & -- & -- & -- & -- & -- & -- & -- & -- & -- & -- & -- & None \\
\hline $3 / 21$ & $8: 00$ & M & 405.00 & 404.30 & 45 & 49 & 29 & 57 & OFF & $\mathrm{OFF}$ & OFF & 7" & 8.75 & 9.75 & 0.00 & None \\
\hline $3 / 22$ & $12: 30$ & M & 404.90 & 404.30 & 46 & 49 & 29 & 59 & OFF & OFF & OFF & 7" & 8.75 & 9.75 & 0.00 & None \\
\hline $3 / 23$ & $11: 40$ & $\mathrm{~L}$ & 404.90 & 404.30 & 46 & 50 & 32 & 64 & OFF & OFF & OFF & $7 "$ & 8.75 & 9.75 & 0.00 & None \\
\hline $3 / 24$ & $13: 10$ & $\mathrm{~L}$ & 404.80 & 404.25 & 48 & 50 & 36 & 61 & OFF & OFF & OFF & 7" & 12.75 & 13.00 & 12.75 & None \\
\hline $3 / 25$ & $9: 00$ & $\mathrm{~L}$ & 404.80 & 404.30 & 48 & 50 & 46 & 64 & OFF & OFF & OFF & $7 "$ & 10.50 & 11.50 & 11.25 & None \\
\hline $3 / 25$ & $13: 00$ & $\mathrm{~L}$ & 404.90 & 404.30 & -- & -- & -- & -- & -- & -- & -- & -- & -- & -- & -- & None \\
\hline $3 / 26$ & $9: 45$ & $\mathrm{~L}$ & 405.00 & 404.30 & 49 & 53 & 41 & 63 & OFF & OFF & OFF & 7" & 9.25 & 10.00 & 9.25 & None \\
\hline $3 / 26$ & $14: 00$ & -- & 405.10 & 404.30 & -- & -- & -- & -- & -- & -- & -- & -- & -- & -- & -- & None \\
\hline $3 / 27^{d}$ & $10: 15$ & M & 405.00 & 404.00 & 46 & 50 & 31 & 56 & OFF & $\mathrm{OFF}$ & OFF & 7" & 11.00 & 10.75 & 11.00 & None \\
\hline $3 / 28$ & $9: 30$ & M & 404.90 & 403.95 & 45 & 48 & 36 & 53 & OFF & OFF & OFF & $7 "$ & 8.75 & 8.00 & 8.50 & None \\
\hline $3 / 29$ & $9: 40$ & M & 404.90 & 404.10 & 45 & 48 & 37 & 57 & OFF & OFF & OFF & 7" & 14.00 & 14.00 & 13.75 & None \\
\hline
\end{tabular}

a $\mathrm{L}=$ low, $\mathrm{M}=$ moderate, and $\mathrm{H}=$ high.

$b$ Pumpback operations for three pumps (P1, P2, and P3) in the pumpback bay.

$c$ Headgate openings (inches) are for: $\mathrm{S}=$ south gate, $\mathrm{M}=$ middle gate, and $\mathrm{N}=$ north gate.

$d$ West Extension Canal opened. 
Appendix Table 7. Continued.

\begin{tabular}{|c|c|c|c|c|c|c|c|c|c|c|c|c|c|c|c|c|}
\hline \multirow[b]{2}{*}{ Date } & \multirow[b]{2}{*}{ Time } & \multirow[b]{2}{*}{ Debris $^{a}$} & \multirow{2}{*}{$\begin{array}{c}\text { River } \\
\text { Gauge (ft.) }\end{array}$} & \multirow{2}{*}{$\begin{array}{c}\text { Canal } \\
\text { Height (ft.) }\end{array}$} & \multicolumn{2}{|c|}{ Water Temp. $\left({ }^{\circ} \mathrm{F}\right)$} & \multicolumn{2}{|c|}{ Air Temp. $\left({ }^{\circ} \mathrm{F}\right)$} & \multicolumn{3}{|c|}{ Pumpback Operations $s^{b}$} & \multirow{2}{*}{$\begin{array}{c}\text { River-return } \\
\text { Pipe Opening }\end{array}$} & \multicolumn{3}{|c|}{ Headgate Openings $s^{c}$} & \multirow{2}{*}{$\begin{array}{c}\text { Phase I } \\
\text { Exchange }\end{array}$} \\
\hline & & & & & Min. & Max. & Min. & Max. & $\mathrm{P} 1$ & $\mathrm{P} 2$ & $\mathrm{P} 3$ & & $\mathrm{~S}$ & $\mathrm{M}$ & $\mathrm{N}$ & \\
\hline $3 / 30$ & $11: 38$ & $\mathrm{~L}$ & 404.90 & 404.05 & 47 & 50 & 44 & 57 & OFF & OFF & OFF & $7 "$ & 14.00 & 14.00 & 13.75 & None \\
\hline $3 / 31$ & $11: 25$ & M & 404.90 & 404.05 & 48 & 51 & 41 & 60 & OFF & OFF & OFF & $7 "$ & 14.00 & 14.00 & 13.75 & None \\
\hline $4 / 1$ & $9: 30$ & $\mathrm{~L}$ & 404.90 & 404.00 & 46 & 50 & 40 & 56 & OFF & OFF & OFF & $7 "$ & 14.00 & 14.00 & 13.75 & None \\
\hline $4 / 1$ & $12: 00$ & $\mathrm{~L}$ & 404.90 & 404.00 & -- & -- & -- & -- & -- & -- & -- & -- & -- & -- & -- & None \\
\hline $4 / 2$ & $10: 00$ & $\mathrm{~L}$ & 405.00 & 404.15 & 45 & 48 & 38 & 54 & OFF & OFF & OFF & $7 "$ & 13.00 & 13.00 & 13.00 & None \\
\hline $4 / 2$ & $13: 00$ & $\mathrm{~L}$ & 405.00 & 404.00 & -- & -- & -- & -- & -- & -- & -- & -- & -- & -- & -- & None \\
\hline $4 / 4$ & $17: 00$ & $\mathrm{~L}$ & 404.90 & 404.00 & 46 & 48 & 42 & 54 & OFF & OFF & OFF & 7" & -- & -- & -- & None \\
\hline $4 / 6$ & $12: 15$ & $\mathrm{~L}$ & 404.90 & 404.00 & 45 & 49 & 30 & 59 & OFF & OFF & OFF & 7" & 13.00 & 13.00 & 13.00 & None \\
\hline $4 / 7$ & $12: 10$ & $\mathrm{~L}$ & 404.90 & 404.00 & 47 & 50 & 38 & 55 & OFF & OFF & OFF & 7" & 13.00 & 13.00 & 13.00 & None \\
\hline $4 / 8$ & 9:00 & $\mathrm{L}$ & 404.90 & 404.00 & 44 & 50 & 36 & 52 & OFF & OFF & OFF & 7" & 13.00 & 13.00 & 1.00 & None \\
\hline $4 / 9$ & $9: 30$ & $\mathrm{~L}$ & 404.90 & 404.20 & 42 & 48 & 29 & 57 & OFF & OFF & OFF & 7" & 12.00 & 12.00 & 12.00 & None \\
\hline $4 / 9$ & $12: 00$ & $\mathrm{~L}$ & 404.90 & 404.00 & -- & -- & -- & -- & -- & -- & -- & -- & -- & -- & -- & None \\
\hline $4 / 10$ & $12: 45$ & $\mathrm{~L}$ & 404.90 & 404.00 & 49 & 49 & 39 & 60 & OFF & OFF & OFF & 7" & 12.00 & 12.00 & 12.00 & None \\
\hline $4 / 11$ & $12: 15$ & $\mathrm{~L}$ & 404.90 & 404.00 & 48 & 50 & 40 & 57 & OFF & OFF & OFF & 7" & 12.00 & 12.00 & 12.00 & None \\
\hline $4 / 13$ & $12: 30$ & $\mathrm{M}$ & 405.05 & 404.15 & 45 & 48 & 38 & 55 & OFF & OFF & OFF & 7" & 12.00 & 12.00 & 12.00 & None \\
\hline $4 / 14$ & $12: 00$ & $\mathrm{~L}$ & 404.90 & 404.00 & 45 & 49 & 31 & 55 & OFF & OFF & OFF & 7" & 10.50 & 10.50 & 10.50 & None \\
\hline $4 / 15$ & $9: 30$ & $\mathrm{~L}$ & 404.90 & 404.05 & 46 & 48 & 35 & 58 & OFF & OFF & OFF & 7" & 12.25 & 12.00 & 12.00 & None \\
\hline $4 / 15$ & $12: 45$ & $\mathrm{~L}$ & 404.90 & 404.05 & -- & -- & -- & -- & -- & -- & -- & -- & -- & -- & -- & None \\
\hline $4 / 16$ & $9: 20$ & $\mathrm{~L}$ & 404.85 & 404.00 & 47 & 52 & 40 & 63 & OFF & OFF & OFF & 5" & 12.25 & 12.00 & 12.00 & None \\
\hline $4 / 17$ & $8: 30$ & $\mathrm{~L}$ & 404.90 & 403.95 & 50 & 55 & 48 & 71 & OFF & OFF & OFF & 7" & 14.00 & 14.00 & 14.00 & None \\
\hline $4 / 18$ & $8: 15$ & $\mathrm{~L}$ & 404.90 & 404.05 & 53 & 58 & 43 & 66 & OFF & OFF & OFF & 7" & 14.25 & 14.00 & 14.00 & None \\
\hline $4 / 19$ & $10: 45$ & $\mathrm{~L}$ & 405.05 & 404.20 & 48 & 54 & 40 & 55 & OFF & OFF & OFF & 7" & 14.25 & 14.00 & 14.00 & None \\
\hline $4 / 20$ & $12: 00$ & $\mathrm{~L}$ & 404.95 & 404.10 & 48 & 54 & 38 & 67 & OFF & OFF & OFF & 7" & 14.25 & 14.00 & 14.00 & None \\
\hline $4 / 21$ & $12: 00$ & $\mathrm{M}$ & 404.90 & 404.05 & 50 & 54 & 40 & 64 & OFF & OFF & OFF & 7" & 14.5 & 14.00 & 14.00 & None \\
\hline $4 / 22$ & 9:00 & $\mathrm{L}$ & 404.85 & 404.00 & 50 & 54 & 40 & 68 & OFF & OFF & OFF & 7" & 17.25 & 16.25 & 16.25 & None \\
\hline $4 / 22$ & -- & $\mathrm{L}$ & 404.80 & 404.00 & -- & -- & -- & -- & -- & -- & -- & -- & -- & -- & -- & None \\
\hline $4 / 23$ & 9:00 & $\mathrm{L}$ & 404.80 & 404.00 & 49 & 56 & 46 & 62 & OFF & OFF & OFF & 7" & 17.25 & 16.25 & 16.25 & None \\
\hline $4 / 23$ & $13: 30$ & $\mathrm{~L}$ & 404.75 & 404.00 & -- & -- & -- & -- & -- & -- & -- & -- & -- & -- & -- & None \\
\hline $4 / 24$ & $12: 30$ & $\mathrm{~L}$ & 404.75 & 404.00 & 49 & 55 & 42 & 67 & OFF & OFF & OFF & 7" & 17.25 & 16.25 & 16.25 & None \\
\hline $4 / 28$ & $12: 00$ & $\mathrm{M}$ & 405.00 & 404.10 & 53 & 62 & 48 & 82 & OFF & OFF & OFF & 7" & 19.00 & 19.00 & 19.00 & None \\
\hline $4 / 29$ & $9: 30$ & -- & 405.00 & 404.05 & 51 & 58 & 38 & 63 & OFF & OFF & OFF & 7" & 16.75 & 16.75 & 17.00 & None \\
\hline
\end{tabular}


Appendix Table 7. Continued.

\begin{tabular}{|c|c|c|c|c|c|c|c|c|c|c|c|c|c|c|c|c|}
\hline \multirow[b]{2}{*}{ Date } & \multirow[b]{2}{*}{ Time } & \multirow[b]{2}{*}{ Debris $^{a}$} & \multirow{2}{*}{$\begin{array}{c}\text { River } \\
\text { Gauge (ft.) }\end{array}$} & \multirow{2}{*}{$\begin{array}{c}\text { Canal } \\
\text { Height (ft.) }\end{array}$} & \multicolumn{2}{|c|}{ Water Temp. $\left({ }^{\circ} \mathrm{F}\right)$} & \multicolumn{2}{|c|}{ Air Temp. $\left({ }^{\circ} \mathrm{F}\right)$} & \multicolumn{3}{|c|}{ Pumpback Operations $^{b}$} & \multirow{2}{*}{$\begin{array}{c}\text { River-return } \\
\text { Pipe Opening }\end{array}$} & \multicolumn{3}{|c|}{ Headgate Openings ${ }^{c}$} & \multirow{2}{*}{$\begin{array}{c}\text { Phase I } \\
\text { Exchange }\end{array}$} \\
\hline & & & & & Min. & Max. & Min. & Max. & $\mathrm{P} 1$ & $\mathrm{P} 2$ & $\mathrm{P} 3$ & & $\mathrm{~S}$ & $\mathrm{M}$ & $\mathrm{N}$ & \\
\hline $4 / 30$ & $8: 45$ & $\mathrm{M}$ & 404.85 & 403.95 & 50 & 52 & 48 & 64 & OFF & OFF & OFF & $7 "$ & 16.75 & 16.75 & 17.00 & None \\
\hline $5 / 1$ & 9:00 & $\mathrm{L}$ & 404.85 & 404.00 & 50 & 52 & 41 & 59 & OFF & OFF & OFF & 7" & 16.75 & 16.75 & 17.00 & None \\
\hline $5 / 1$ & $14: 30$ & -- & 405.05 & -- & -- & -- & -- & -- & -- & -- & -- & -- & -- & -- & -- & None \\
\hline $5 / 2$ & $12: 00$ & M & 405.05 & 404.00 & 49 & 52 & 38 & 61 & OFF & OFF & OFF & $7 "$ & 15.75 & 15.75 & 15.75 & None \\
\hline $5 / 3$ & $11: 45$ & $\mathrm{M}$ & 404.90 & 403.95 & 50 & 53 & 36 & 65 & OFF & OFF & OFF & 7" & 15.75 & 15.75 & 15.75 & None \\
\hline $5 / 4$ & $12: 20$ & -- & 404.80 & 403.80 & 50 & 55 & 45 & 70 & OFF & OFF & OFF & $7 "$ & 15.75 & 15.75 & 15.75 & None \\
\hline $5 / 5$ & $12: 00$ & $\mathrm{~L}$ & 404.80 & 403.80 & 52 & 58 & 48 & 79 & -- & -- & -- & -- & 15.75 & 15.75 & 15.75 & None \\
\hline $5 / 6$ & $9: 30$ & $\mathrm{~L}$ & 404.75 & 403.80 & 52 & 58 & 36 & 66 & OFF & OFF & OFF & 7" & 16.75 & 16.75 & 16.75 & None \\
\hline $5 / 6$ & $17: 00$ & -- & -- & 403.95 & -- & -- & -- & -- & -- & -- & -- & -- & 17.75 & 17.75 & 17.75 & None \\
\hline $5 / 8$ & $12: 00$ & $\mathrm{~L}$ & 404.70 & 403.90 & 50 & 58 & 40 & 78 & OFF & OFF & OFF & 7" & 18.75 & 18.75 & 18.75 & None \\
\hline $5 / 9$ & 19:00 & $\mathrm{L}$ & 404.60 & 403.90 & 58 & 62 & 45 & 81 & OFF & OFF & OFF & 7" & 23.25 & 23.25 & 23.25 & None \\
\hline $5 / 10$ & $14: 45$ & $\mathrm{~L}$ & 404.50 & 403.90 & 60 & 61 & 55 & 72 & OFF & OFF & OFF & 7" & 23.25 & 23.25 & 23.25 & None \\
\hline $5 / 11$ & $14: 30$ & $\mathrm{~L}$ & 404.50 & 403.90 & 60 & 62 & 56 & 78 & OFF & OFF & OFF & 7" & 23.25 & 23.25 & 23.25 & None \\
\hline $5 / 12$ & $12: 00$ & $\mathrm{~L}$ & 404.40 & 403.90 & 60 & 63 & 50 & 87 & OFF & OFF & OFF & 7" & 23.25 & 23.25 & 23.25 & None \\
\hline $5 / 13$ & $9: 45$ & $\mathrm{~L}$ & 404.40 & 403.85 & 61 & 66 & 55 & 89 & OFF & OFF & OFF & 7" & 29.00 & 29.00 & 29.00 & None \\
\hline $5 / 14$ & $9: 30$ & $\mathrm{~L}$ & 404.40 & 404.05 & 60 & 64 & 55 & 73 & OFF & OFF & OFF & 7" & 26.75 & 27.00 & 28.00 & None \\
\hline $5 / 14$ & -- & -- & 404.40 & 404.05 & -- & -- & -- & -- & -- & -- & -- & -- & -- & -- & -- & None \\
\hline $5 / 16$ & $11: 45$ & $\mathrm{~L}$ & 404.50 & 404.10 & 62 & 63 & 45 & 67 & OFF & OFF & OFF & $7 "$ & 26.75 & 27.00 & 28.00 & None \\
\hline $5 / 17$ & $13: 45$ & $\mathrm{~L}$ & 404.45 & 404.10 & 57 & 61 & 42 & 68 & OFF & OFF & OFF & 7" & 28.50 & 28.50 & 28.75 & None \\
\hline $5 / 18$ & $12: 30$ & $\mathrm{~L}$ & 404.45 & 404.15 & 58 & 60 & 41 & 67 & OFF & OFF & OFF & 7" & 27.50 & 27.25 & 27.25 & None \\
\hline $5 / 19$ & $12: 00$ & $\mathrm{~L}$ & 404.40 & 404.15 & 58 & 62 & 44 & 77 & OFF & OFF & OFF & 7" & 27.50 & 27.25 & 27.25 & None \\
\hline $5 / 20$ & $10: 30$ & $\mathrm{~L}$ & 404.40 & 404.10 & 57 & 64 & 42 & 76 & OFF & OFF & OFF & 7" & 27.75 & 27.00 & 27.25 & None \\
\hline $5 / 21$ & $10: 00$ & $\mathrm{~L}$ & 404.50 & 404.40 & 56 & 64 & 45 & 72 & OFF & OFF & OFF & 7" & 27.50 & 22.75 & 0.00 & Partial \\
\hline $5 / 22$ & $12: 30$ & $\mathrm{~L}$ & 404.45 & 404.50 & 58 & 67 & 49 & 81 & OFF & OFF & OFF & 7" & 27.75 & 23.00 & 0.00 & Full \\
\hline $5 / 23$ & $13: 15$ & $\mathrm{~L}$ & 404.40 & 404.45 & 62 & 70 & 57 & 89 & OFF & OFF & OFF & 7" & 27.50 & 23.00 & 0.00 & Full \\
\hline $5 / 24$ & $12: 00$ & $\mathrm{~L}$ & 404.40 & 404.40 & 67 & 74 & 63 & 101 & OFF & OFF & OFF & 7" & 27.50 & 23.00 & 0.00 & Full \\
\hline $5 / 25$ & $12: 00$ & $\mathrm{~L}$ & 404.40 & 404.40 & 68 & 77 & 63 & 99 & -- & -- & -- & -- & 27.50 & 23.00 & 0.00 & Full \\
\hline $5 / 26$ & $12: 30$ & $\mathrm{~L}$ & 404.40 & 404.40 & 70 & 75 & 58 & 100 & -- & -- & -- & -- & 27.50 & 23.00 & 0.00 & Full \\
\hline $5 / 27$ & $10: 30$ & $\mathrm{~L}$ & 403.05 & 404.40 & 70 & 74 & 62 & 94 & OFF & OFF & OFF & 7" & 27.50 & 23.00 & 0.00 & Full \\
\hline $5 / 28$ & $9: 30$ & $\mathrm{~L}$ & 404.30 & 404.35 & 64 & 72 & 51 & 86 & OFF & OFF & OFF & $7^{\prime \prime}$ & 27.50 & 23.00 & 0.00 & Full \\
\hline $5 / 29$ & $12: 30$ & $\mathrm{~L}$ & 404.40 & 404.40 & 62 & 68 & 40 & 75 & OFF & OFF & OFF & 7" & 27.50 & 23.00 & 0.00 & Full \\
\hline
\end{tabular}


Appendix Table 7. Continued.

\begin{tabular}{|c|c|c|c|c|c|c|c|c|c|c|c|c|c|c|c|c|}
\hline \multirow[b]{2}{*}{ Date } & \multirow[b]{2}{*}{ Time } & \multirow[b]{2}{*}{ Debris $^{a}$} & \multirow{2}{*}{$\begin{array}{c}\text { River } \\
\text { Gauge (ft.) }\end{array}$} & \multirow{2}{*}{$\begin{array}{c}\text { Canal } \\
\text { Height (ft.) }\end{array}$} & \multicolumn{2}{|c|}{ Water Temp. $\left({ }^{\circ} \mathrm{F}\right)$} & \multicolumn{2}{|c|}{ Air Temp. $\left({ }^{\circ} \mathrm{F}\right)$} & \multicolumn{3}{|c|}{ Pumpback Operations $^{b}$} & \multirow{2}{*}{$\begin{array}{l}\text { River-return } \\
\text { Pipe Opening }\end{array}$} & \multicolumn{3}{|c|}{ HeadgateOopenings $^{c}$} & \multirow{2}{*}{$\begin{array}{l}\text { Phase I } \\
\text { Exchange }\end{array}$} \\
\hline & & & & & Min. & Max. & Min. & Max. & P1 & $\mathrm{P} 2$ & $\mathrm{P} 3$ & & $\mathrm{~S}$ & $\mathrm{M}$ & $\mathrm{N}$ & \\
\hline $5 / 30$ & $12: 00$ & $\mathrm{~L}$ & 404.40 & 404.40 & 62 & 68 & 45 & 75 & OFF & OFF & OFF & $7 "$ & 27.50 & 23.00 & 0.00 & Full \\
\hline $5 / 31$ & $12: 15$ & $\mathrm{~L}$ & 404.40 & 404.40 & 62 & 68 & 54 & 90 & OFF & OFF & OFF & 7" & 27.50 & 23.00 & 0.00 & Full \\
\hline $6 / 1$ & $11: 30$ & $\mathrm{~L}$ & 404.40 & 404.40 & 66 & 70 & 56 & 90 & OFF & OFF & OFF & $7 "$ & 27.50 & 23.00 & 0.00 & Full \\
\hline $6 / 2$ & $12: 00$ & $\mathrm{~L}$ & 404.40 & 404.40 & 60 & 69 & 48 & 85 & OFF & OFF & OFF & $7 "$ & 27.50 & 23.00 & 0.00 & Full \\
\hline $6 / 3$ & $9: 30$ & $\mathrm{~L}$ & 404.40 & 404.45 & 55 & 66 & 49 & 72 & OFF & OFF & OFF & $7 "$ & 27.50 & 23.00 & 0.00 & Full \\
\hline $6 / 4$ & $11: 00$ & $\mathrm{~L}$ & 404.40 & 404.40 & 54 & 66 & 49 & 72 & OFF & OFF & OFF & 7" & 27.50 & 23.00 & 0.00 & Full \\
\hline $6 / 5$ & $15: 00$ & $\mathrm{~L}$ & 404.40 & 404.40 & 58 & 64 & 54 & 75 & OFF & OFF & OFF & $7 "$ & 27.50 & 23.00 & 0.00 & Full \\
\hline $6 / 6$ & $12: 30$ & $\mathrm{~L}$ & 404.40 & 404.40 & 58 & 63 & 50 & 70 & OFF & OFF & OFF & $7 "$ & 27.50 & 23.00 & 0.00 & Full \\
\hline $6 / 8$ & $14: 30$ & $\mathrm{~L}$ & 404.40 & 404.40 & 60 & 68 & 56 & 90 & OFF & OFF & OFF & $7 "$ & 27.50 & 23.00 & 0.00 & Full \\
\hline $6 / 9$ & $12: 00$ & $\mathrm{~L}$ & 404.40 & 404.35 & -- & -- & 60 & 88 & OFF & OFF & OFF & $7 "$ & -- & -- & -- & Full \\
\hline $6 / 11$ & $11: 30$ & $\mathrm{~L}$ & 404.40 & 404.30 & 61 & 68 & 50 & 78 & OFF & $\mathrm{OFF}$ & OFF & 7" & -- & -- & -- & Full \\
\hline $6 / 12$ & 8:00 & $\mathrm{L}$ & 404.35 & 404.35 & 58 & 63 & 47 & 72 & OFF & $\mathrm{OFF}$ & OFF & 7" & 27.50 & 23.00 & 0.00 & Full \\
\hline $6 / 13$ & $12: 00$ & $\mathrm{~L}$ & 404.40 & 404.40 & 54 & 60 & 50 & 67 & OFF & $\mathrm{OFF}$ & OFF & 7" & 27.50 & 23.00 & 0.00 & Full \\
\hline $6 / 21$ & $10: 00$ & M & 404.40 & 404.40 & 62 & 70 & 48 & 90 & OFF & OFF & OFF & 7" & 27.50 & 23.00 & 0.00 & Full \\
\hline $6 / 22$ & $8: 30$ & $\mathrm{~L}$ & 404.35 & 404.35 & 68 & 73 & 59 & 107 & OFF & OFF & OFF & 7" & 27.50 & 23.00 & 0.00 & Full \\
\hline $6 / 25$ & $16: 30$ & $\mathrm{~L}$ & 404.35 & 404.35 & 60 & 70 & 46 & 89 & OFF & $\mathrm{OFF}$ & OFF & 7" & 27.50 & 23.00 & 0.00 & Full \\
\hline $6 / 27$ & $16: 00$ & $\mathrm{~L}$ & 404.35 & 404.35 & 65 & 67 & 59 & 80 & OFF & $\mathrm{OFF}$ & OFF & 7" & 27.50 & 23.00 & 0.00 & Full \\
\hline $6 / 29$ & $15: 00$ & $\mathrm{~L}$ & 404.35 & 404.35 & 66 & 70 & 56 & 86 & OFF & $\mathrm{OFF}$ & OFF & 7" & 27.50 & 23.00 & 0.00 & Full \\
\hline $7 / 2$ & $16: 30$ & -- & 404.35 & 404.35 & 66 & 72 & 58 & 90 & OFF & $\mathrm{OFF}$ & OFF & 7" & 27.50 & 23.00 & 0.00 & Full \\
\hline $7 / 3$ & $8: 30$ & $\mathrm{~L}$ & 404.30 & 404.20 & 70 & 72 & -- & -- & ON & OFF & OFF & OFF & 27.50 & 22.75 & 12.00 & Partial \\
\hline $7 / 5$ & $16: 00$ & $\mathrm{H}$ & 404.30 & 404.20 & 70 & 76 & -- & -- & $\mathrm{ON}$ & $\mathrm{OFF}$ & OFF & OFF & 27.50 & 22.75 & 12.00 & Partial \\
\hline $7 / 6$ & 9:00 & M & 404.30 & 404.20 & 68 & 72 & 57 & 95 & $\mathrm{ON}$ & $\mathrm{OFF}$ & OFF & OFF & 27.50 & 22.75 & 12.00 & Partial \\
\hline $8 / 16$ & -- & -- & -- & -- & -- & -- & -- & -- & -- & -- & -- & -- & -- & -- & -- & Full \\
\hline $8 / 20$ & $11: 30$ & M & 404.20 & 404.30 & -- & -- & -- & -- & OFF & $\mathrm{OFF}$ & OFF & $3 "$ & -- & -- & -- & Full \\
\hline $8 / 21$ & $8: 30$ & $\mathrm{~L}$ & 403.90 & 404.00 & 62 & 70 & 58 & 86 & OFF & OFF & OFF & $3 "$ & 27.50 & 34.50 & 34.00 & Full \\
\hline $8 / 21$ & $9: 45$ & -- & 404.00 & 404.00 & -- & -- & -- & -- & $\mathrm{ON}$ & $\mathrm{OFF}$ & OFF & OFF & -- & -- & -- & Full \\
\hline $8 / 23$ & $9: 30$ & M & 404.30 & 404.30 & 64 & 70 & 61 & 84 & $\mathrm{ON}$ & $\mathrm{OFF}$ & OFF & OFF & 27.50 & 34.50 & 34.00 & Full \\
\hline $8 / 24$ & $9: 45$ & $\mathrm{~L}$ & 404.40 & 404.45 & 65 & 69 & 54 & 77 & OFF & OFF & OFF & $3 "$ & 27.50 & 34.50 & 34.00 & Full \\
\hline $8 / 27$ & $10: 40$ & $\mathrm{~L}$ & 403.80 & 404.20 & 64 & 70 & 53 & 89 & $\mathrm{ON}$ & OFF & OFF & OFF & 27.50 & 34.50 & 34.00 & Full \\
\hline $8 / 29$ & $10: 45$ & M & 404.10 & 404.30 & 66 & 71 & 59 & 91 & OFF & OFF & OFF & OFF & 27.50 & 34.50 & 34.00 & Full \\
\hline $9 / 17$ & $10: 30$ & $\mathrm{~L}$ & 404.40 & 404.50 & 62 & 72 & 47 & 93 & OFF & $\mathrm{OFF}$ & OFF & 4" & 27.50 & 34.50 & 34.00 & Full \\
\hline
\end{tabular}


Appendix Table 7. Continued.

\begin{tabular}{|c|c|c|c|c|c|c|c|c|c|c|c|c|c|c|c|c|}
\hline \multirow[b]{2}{*}{ Date } & \multirow[b]{2}{*}{ Time } & \multirow[b]{2}{*}{ Debris $^{a}$} & \multirow{2}{*}{$\begin{array}{c}\text { River } \\
\text { Gauge (ft.) }\end{array}$} & \multirow{2}{*}{$\begin{array}{c}\text { Canal } \\
\text { Height (ft.) }\end{array}$} & \multicolumn{2}{|c|}{ Water Temp. $\left({ }^{\circ} \mathrm{F}\right)$} & \multicolumn{2}{|c|}{ Air Temp. $\left({ }^{\circ} \mathrm{F}\right)$} & \multicolumn{3}{|c|}{ Pumpback Operations $^{b}$} & \multirow{2}{*}{$\begin{array}{c}\text { River-return } \\
\text { Pipe Opening }\end{array}$} & \multicolumn{3}{|c|}{ Headgate Openings ${ }^{c}$} & \multirow{2}{*}{$\begin{array}{r}\text { Phase I } \\
\text { Exchang } \\
\end{array}$} \\
\hline & & & & & Min. & Max. & Min. & Max. & $\mathrm{P} 1$ & $\mathrm{P} 2$ & $\mathrm{P} 3$ & & $\mathrm{~S}$ & $\mathrm{M}$ & $\mathrm{N}$ & \\
\hline $9 / 19$ & $12: 00$ & $\mathrm{~L}$ & 404.40 & 404.45 & 64 & 67 & 54 & 86 & OFF & OFF & OFF & $5 "$ & 27.50 & 34.50 & 34.00 & Full \\
\hline $9 / 21$ & $12: 00$ & -- & 404.40 & 404.45 & 62 & 64 & 50 & 78 & OFF & OFF & OFF & $5 "$ & 27.50 & 34.50 & 34.00 & Full \\
\hline $9 / 24$ & $9: 00$ & $\mathrm{~L}$ & 404.40 & 404.50 & 61 & 63 & 52 & 82 & OFF & OFF & OFF & $5 "$ & 27.50 & 34.50 & 34.00 & Full \\
\hline $9 / 26$ & $10: 30$ & $\mathrm{H}$ & 404.40 & 404.45 & 61 & 64 & 52 & 86 & OFF & OFF & OFF & $5 "$ & 27.50 & 34.50 & 34.00 & Full \\
\hline $9 / 28$ & 13:00 & $\mathrm{M}$ & 404.40 & 404.50 & 59 & 62 & 46 & 72 & OFF & $\mathrm{OFF}$ & OFF & 5" & 27.50 & 34.50 & 34.00 & Full \\
\hline
\end{tabular}


Appendix Table 8. Releases of hatchery chinook salmon, coho salmon, and summer steelhead in the Umatilla River, March 2001 - June 2001.

\begin{tabular}{|c|c|c|c|c|c|c|c|}
\hline Species $^{a}$ & Age & $\begin{array}{c}\text { Hatchery } \\
\text { origin }\end{array}$ & $\begin{array}{l}\text { Release } \\
{\text { date }(\mathrm{s})^{b}}^{\text {nat }}\end{array}$ & $\begin{array}{c}\text { Release } \\
\text { location }^{\mathrm{c}}\end{array}$ & $\begin{array}{c}\text { River } \\
\text { mile }\end{array}$ & $\begin{array}{l}\text { Number } \\
\text { released }\end{array}$ & $\begin{array}{l}\text { Number } \\
\text { CWT }^{d}\end{array}$ \\
\hline CHS & $1+$ & $\mathrm{LWSH}^{e}$ & $3 / 10-3 / 16$ & Imeques & 80.0 & 165,310 & 18,266 \\
\hline CHS & $1+$ & Umatilla & $3 / 3-3 / 9$ & Imeques & 80.0 & 336,521 & 136,530 \\
\hline CHS & $1+$ & Carson & $4 / 11-4 / 17$ & Imeques & 80.0 & 99,983 & 18,398 \\
\hline \multirow[t]{2}{*}{ CHS } & $1+$ & LWSH & $4 / 11-4 / 17$ & Imeques & 80.0 & 180,919 & 18,133 \\
\hline & & & & & Total & 782,733 & 191,327 \\
\hline CHF & $1+$ & Bonneville & $3 / 10-3 / 16$ & Thornhollow & 73.5 & 213,499 & 17,993 \\
\hline \multirow[t]{2}{*}{$\mathrm{CHF}$} & $1+$ & Bonneville & $4 / 13-4 / 19$ & Thornhollow & 73.5 & 187,262 & 24,962 \\
\hline & & & & & Total & $400,761^{f}$ & 42,955 \\
\hline CHF & $0+$ & Umatilla & $5 / 21-5 / 24$ & Thornhollow & 73.5 & 324,713 & 316,799 \\
\hline \multirow[t]{2}{*}{$\mathrm{CHF}$} & $0+$ & Umatilla & $5 / 24-5 / 25^{g}$ & Rieth & 48.0 & 322,283 & 317,720 \\
\hline & & & & & Total & 646,996 & 634,519 \\
\hline $\mathrm{COH}$ & $1+$ & $\mathrm{LHCH}^{e}$ & $3 / 10-3 / 14$ & Pendleton & 52.0 & 478,739 & 26,599 \\
\hline $\mathrm{COH}$ & $1+$ & Cascade & $3 / 10-3 / 14$ & Pendleton & 52.0 & 250,323 & $53,255^{h}$ \\
\hline \multirow[t]{2}{*}{$\mathrm{COH}$} & $1+$ & Cascade & $4 / 18-4 / 24$ & Pendleton & 52.0 & 745,497 & 26,474 \\
\hline & & & & & Total & $1,474,559$ & 106,328 \\
\hline STS & $1+$ & Umatilla & $3 / 28-4 / 4$ & Minthorn & 64.5 & 50,829 & 21,065 \\
\hline STS & $1+$ & Umatilla & $3 / 31-4 / 6$ & Bonifer & $79.0^{i}$ & 48,291 & 20,944 \\
\hline \multirow[t]{2}{*}{ STS } & $1+$ & Umatilla & $4 / 23-4 / 26$ & Minthorn & 64.5 & 41,403 & 21,556 \\
\hline & & & & & Total & 140,523 & 63,565 \\
\hline
\end{tabular}

a $\mathrm{CHS}=$ spring chinook salmon, $\mathrm{CHF}=$ fall chinook salmon, $\mathrm{COH}=$ coho salmon, $\mathrm{STS}=$ summer steelhead.

$b$ Date range begins with start of volitional release and ends with forced release.

$c$ All release locations are sites of acclimation facilities, except Rieth where fish were released directly into the stream.

${ }^{d} \mathrm{CWT}=$ coded-wire tagged (and adipose-fin clipped); number is adjusted for tag loss and non-recognizable fin clips.

$e \quad \mathrm{LWSH}=$ Little White Salmon Hatchery, LHCH = Lower Herman Creek Hatchery.

$f$ All CHF1+ not coded-wire tagged received a blank-wire tag.

$g$ Direct stream releases over two days.

$h$ Release consisted of 27,197 fish coded-wire tagged but not adipose- fin clipped.

$i$ River mile 2 of Meacham Creek at river mile 79.0 on the Umatilla River. 
Appendix Table 9. Mean pooled trap efficiency estimates for hatchery and natural juvenile salmonids at West Extension Canal (RM 3.7), March - July 1998-2001.

\begin{tabular}{|c|c|c|c|c|c|c|}
\hline Species $^{a}$ & Year & Mark & $\begin{array}{c}\text { Release } \\
\text { dates }\end{array}$ & $\begin{array}{c}\text { Total } \\
\text { number } \\
\text { released }\end{array}$ & $\begin{array}{c}\text { Total } \\
\text { number } \\
\text { detected }\end{array}$ & $\begin{array}{c}\text { Mean pooled }^{b} \\
\text { trap efficiency (SD) }\end{array}$ \\
\hline \multicolumn{7}{|c|}{ Hatchery } \\
\hline \multirow{4}{*}{ CHS } & 1998 & color & $4 / 14-5 / 5$ & 2,938 & 508 & $0.201(0.029)$ \\
\hline & $1999^{c}$ & PIT-tag & $3 / 11-5 / 14$ & 1,624 & 494 & $0.327(0.196)$ \\
\hline & 2000 & PIT-tag & $3 / 12-5 / 3$ & 508 & 68 & $0.176(0.149)$ \\
\hline & 2001 & PIT-tag & $3 / 12-4 / 30$ & 742 & 144 & $0.206(0.188)$ \\
\hline \multirow[t]{4}{*}{$\mathrm{CHF}$} & 1998 & color & $4 / 5-5 / 18$ & 5,277 & 1,738 & $0.315(0.026)$ \\
\hline & $1999^{c}$ & PIT-tag & $3 / 11-5 / 14$ & 1,624 & 494 & $0.327(0.196)$ \\
\hline & 2000 & PIT-tag & $3 / 12-5 / 11$ & 561 & 138 & $0.325(0.227)$ \\
\hline & 2001 & PIT-tag & $3 / 23-5 / 19$ & 710 & 198 & $0.309(0.134)$ \\
\hline \multirow[t]{4}{*}{ CHF0 } & 1998 & color & $5 / 31-6 / 29$ & 5,683 & 1,323 & $0.235(0.027)$ \\
\hline & 1999 & PIT-tag & $6 / 7-7 / 5$ & 1,517 & 630 & $0.440(0.362)$ \\
\hline & 2000 & PIT-tag & $5 / 27-6 / 17$ & 370 & 102 & $0.273(0.200)$ \\
\hline & 2001 & PIT-tag & $5 / 28-6 / 18$ & 543 & 148 & $0.242(0.113)$ \\
\hline \multirow[t]{4}{*}{$\mathrm{UCOH}$} & 1998 & color & $4 / 19-6 / 3$ & 4,710 & 347 & $0.093(0.019)$ \\
\hline & 1999 & -- & -- & -- & -- & -- \\
\hline & 2000 & -- & -- & -- & -- & -- \\
\hline & 2001 & PIT-tag & $3 / 22-5 / 22$ & 756 & 157 & $0.222(0.090)$ \\
\hline \multirow[t]{4}{*}{ STS } & 1998 & color & $4 / 25-5 / 28$ & 1,723 & 128 & $0.108(0.020)$ \\
\hline & 1999 & PIT-tag & $4 / 20-6 / 2$ & 1,509 & 275 & $0.189(0.036)$ \\
\hline & 2000 & PIT-tag & $4 / 9-6 / 4$ & 471 & 116 & $0.240(0.079)$ \\
\hline & 2001 & PIT-tag & $4 / 9-5 / 29$ & 613 & 154 & $0.213(0.067)$ \\
\hline \multicolumn{7}{|c|}{ Natural } \\
\hline CHF0 & 1998 & color & $6 / 25-7 / 6$ & 1,252 & 156 & $0.124(0.019)$ \\
\hline $\mathrm{CHS}$ & 1999 & PIT-tag & $4 / 1-5 / 25$ & 556 & 240 & $0.453(0.151)$ \\
\hline $\mathrm{CH}$ & 2000 & PIT-tag & $6 / 23-7 / 8$ & 181 & 48 & $0.251(0.105)$ \\
\hline $\mathrm{CH}$ & 2001 & PIT-tag & $6 / 6-6 / 30$ & 344 & 22 & $0.063(0.000)$ \\
\hline \multirow[t]{4}{*}{ STS } & 1998 & color & $4 / 5-5 / 28$ & 1,321 & 120 & $0.124(0.020)$ \\
\hline & 1999 & PIT-tag & $4 / 10-6 / 1$ & 1,557 & 454 & $0.306(0.061)$ \\
\hline & 2000 & PIT-tag & $5 / 18-5 / 20$ & 91 & 27 & $0.325(0.000)$ \\
\hline & 2001 & PIT-tag & $5 / 2-5 / 29$ & 267 & 74 & $0.296(0.136)$ \\
\hline
\end{tabular}

${ }^{a} \mathrm{CHS}=$ Spring chinook Salmon, $\mathrm{CHF}=$ fall chinook salmon, $\mathrm{CHF} 0=$ subyearling fall chinook salmon, $\mathrm{UCOH}=$ coho salmon of unknown origin, STS = summer steelhead, and $\mathrm{CH}=$ chinook of unknown race.

${ }^{b}$ Mean pooled trap efficiency was based on the mean of subpooled estimates from original trap efficiency tables.

$c$ Spring and fall races of yearling chinook salmon could not be separated in 1999. 
